$$
\begin{aligned}
& \text { جامعة الأزهر } \\
& \text { مولية كلية القلة العربية }
\end{aligned}
$$

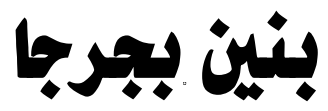

$$
\begin{aligned}
& \text { قواعه التوجيه من الأموليين من النماة } \\
& \text { وأثرها في النهو العربي } \\
& \text { ابن الماجب أنمونجا } \\
& \text { الدبكثور }
\end{aligned}
$$

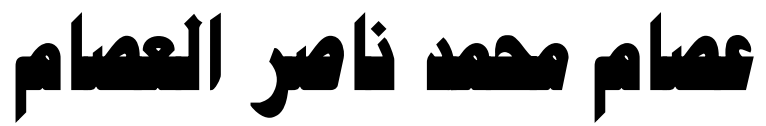

$$
\begin{aligned}
& \text { أستاذ النحو والصرف المساعد في قسم اللفة العربية } \\
& \text { كلية الآداب - جامعة الملك فيصل } \\
& \text { المملكة العربية السعودية الساكية } \\
& \text { العلد الخامس عشر } \\
& \text { كلعام r }
\end{aligned}
$$




\section{الجزء الثالث}

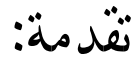

تعد قواعد التوجيه النحوي إحدى العوامل المؤثرة في الدرس النحوي على إلى إلى

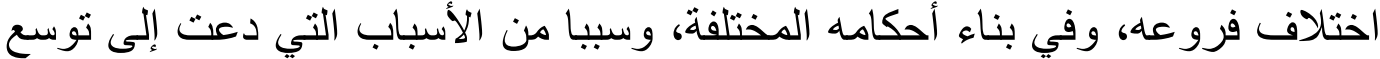

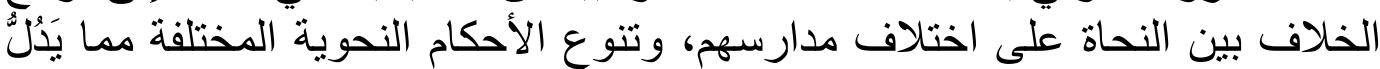

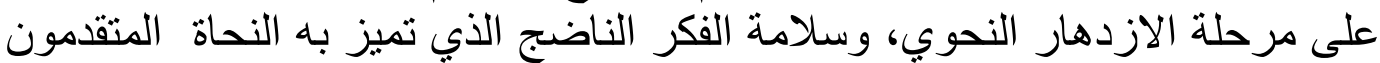

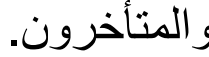

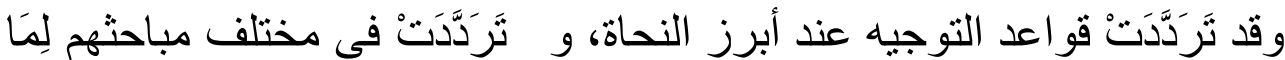

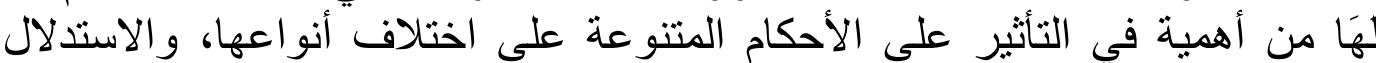

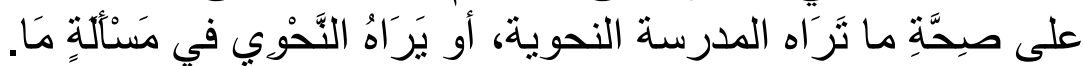

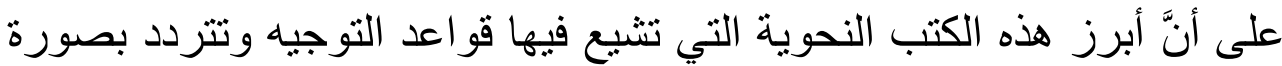

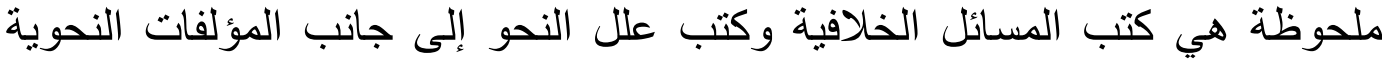
التي اهتمت بالتعليل النحوي في منهجها ثم سائر الكتب النحوية.

و على الرغم من تناثر هذه القو اعد في موروثنا النحوي واللغوي عمومًا إلاًَ أنَّهَ

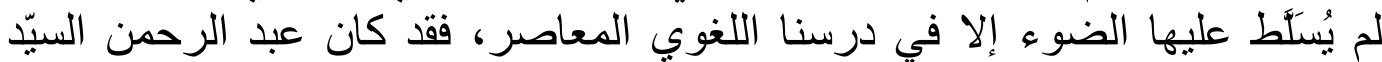

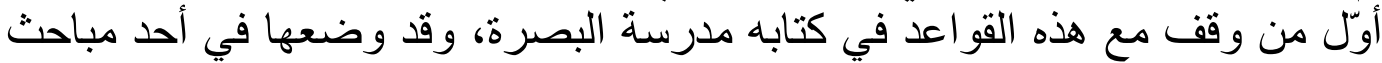

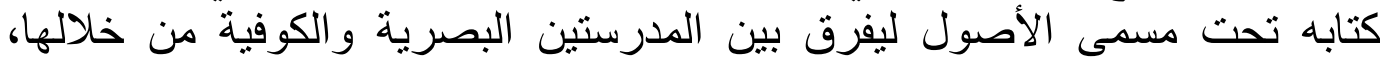
ولكتّه لم يقدّم تعريقًا لها أو تفصيلا.

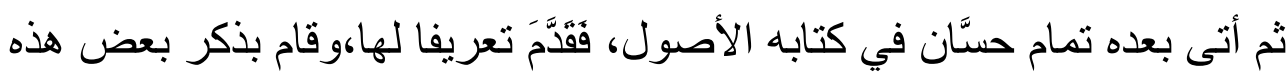

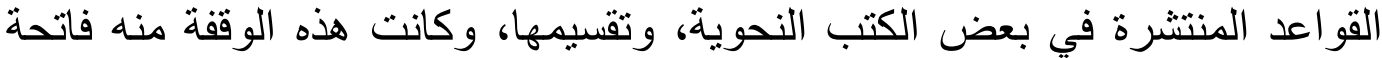
للباحثين الذين تحدثو البعده عن هذه القو اعد.

ولعل من أبرز الباحثين الذين خصّوا هذه القواعد في دراستهم إن لم تكن

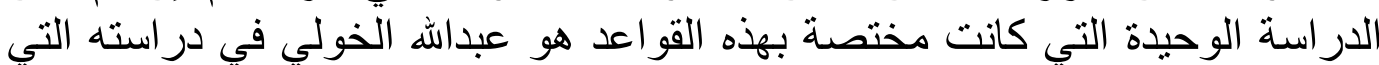

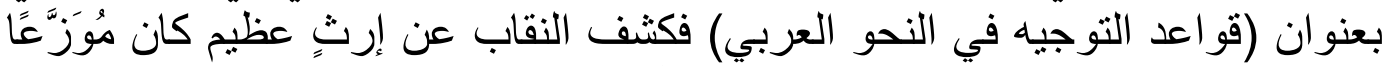
في كتب النحاة المختلفة، فبسط القول فيها، وأبدع في تجميعها وتصنيفها.

أمَّا الدراسات السابقة لهذا البحث فقد اطلعنا عليها، و أفدنا منها، ولكنها لم تكن تهدف

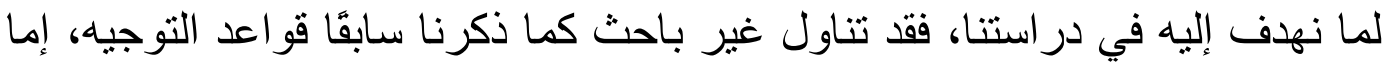


بإثارة سريعة ولمحة فريدة، أو بحديث ضمن حديث آخر ، أو بتفصيل استقصى فيه هذه الظاهرة النحوية، و هذه الدر اسات هي:

ا ـ مدرسة البصرة (نشأتها وتطور ها) د. عبد الرحمن السيد الذي تناول فيها قو اعد

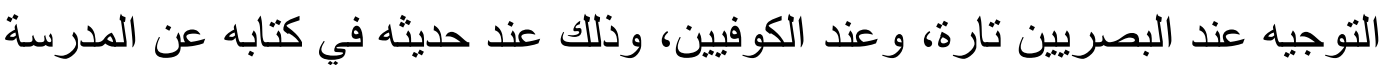
البصرية ونشأتها و أعلامها وخصائصة تأسهاو و أصولها.

وكانت هذه القواعد تحت عنوان أصول المدرسة البصرية، فاعتمد على كتاب

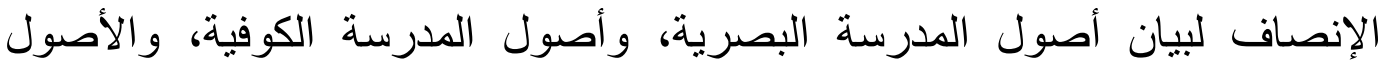
المشتركة بينهما، وموقف كل مدرسة من أصول الأخرى. ولم يذكر كل هذه الأه الأصول، بل اكتفى فقط بالتمثيل.

r- كتاب الأصول دراسة إبستيمولوجية للفكر اللغوي عند العرب، د. تمام حسّان

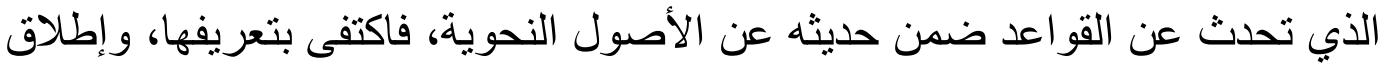

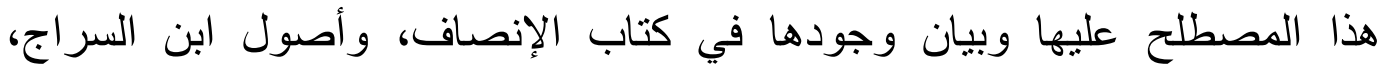

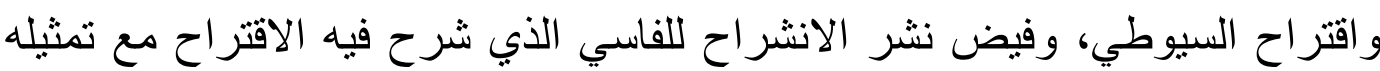

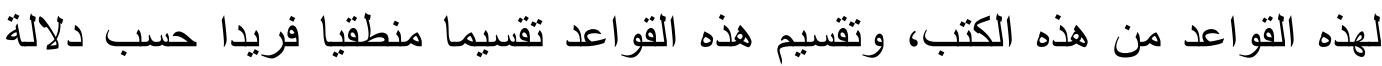

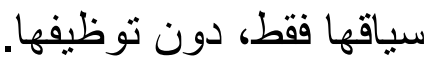
r- الأصول النحوية عند الأنباري،رسالة ماجستير، دار العلوم، ؟9 9 ام، إعداد د. محمد سالم صالح،

وتناولت هذه الدراسة قواعد التوجيه عند الأنباري، إذ تناول الباحث بعضا منها في

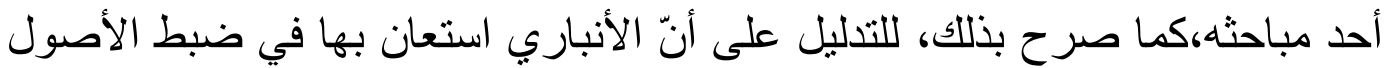

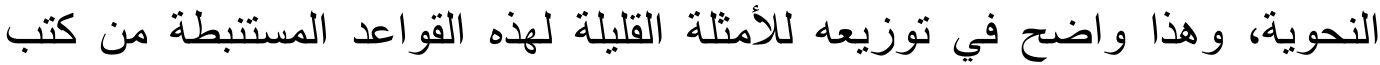

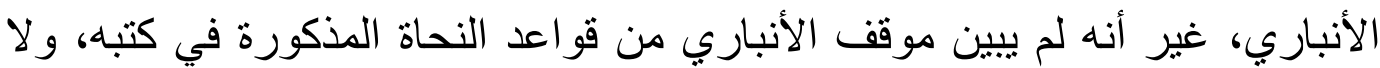

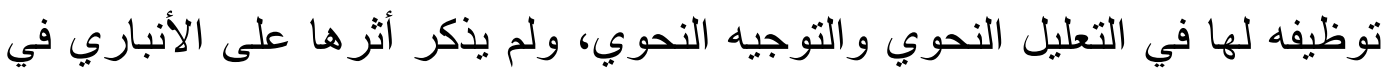

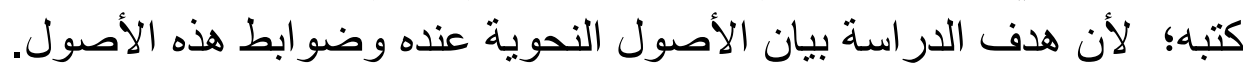

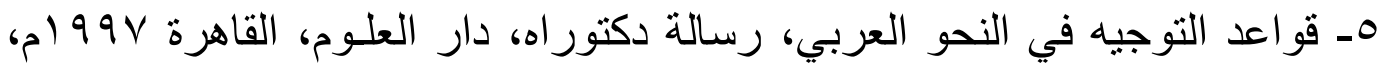

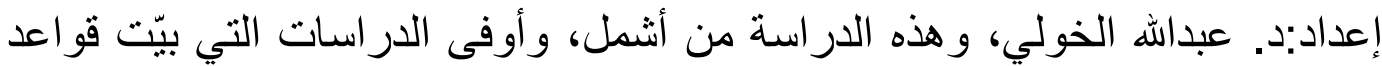
التوجيه في النحو العربي من لان سييويه إلى الأنباري دون تخصيص الته لندي لنحوي معين، 


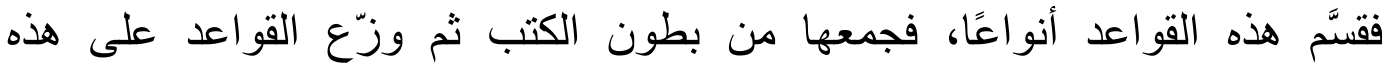

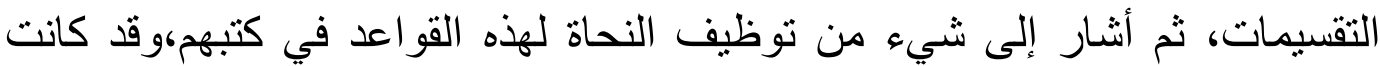

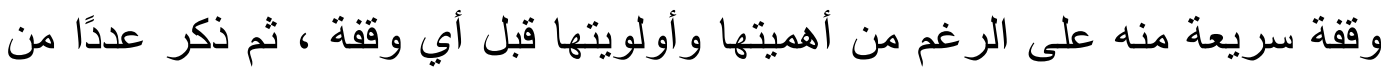

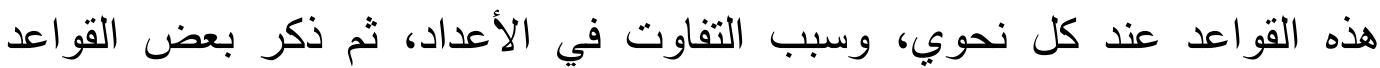
للكوفيين والبصريين، ثم ختم بعلاقة القواعد بالأصول النحوية، و الفقه والمنطق و الفلسفة، إلى أن أبرز أهية قو اعد التوجيه، و المآخذ التي تؤخذ عليها.

ويهذف هذا العمل لبيان قواعد التوجيه في النحو بشكل عام، و عند النحاة دون

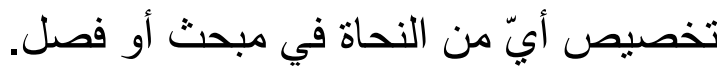

وممن تعرض لقواعد التوجيه بإنشارة وجيزة ضمن دراسة واسعة لا تختص

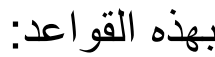

1 - محمود حسن الجاسم في كتابه:(القاعدة النحوية تحليل، ونقا) حيث تناولها ضمن

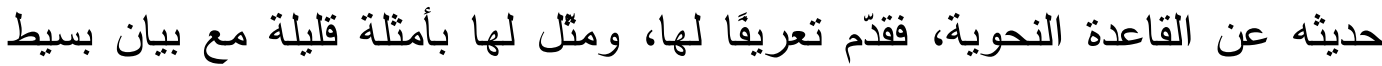
لأهميتها، ومكان وجودها دون إضافة جديدة ثُذكر عمّا ذكره أ.د. تمام حسّان.

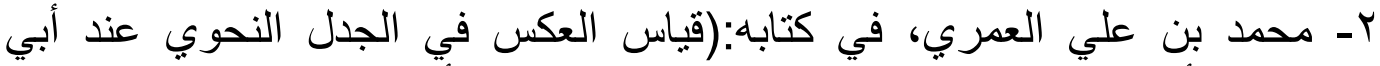

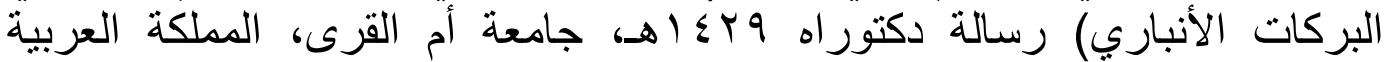

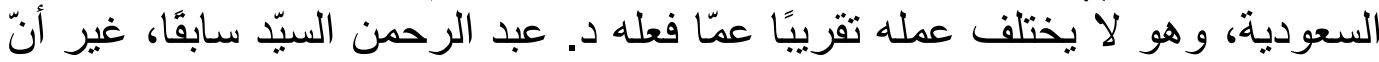

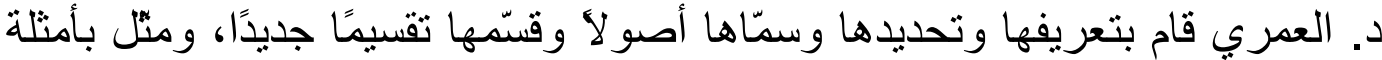

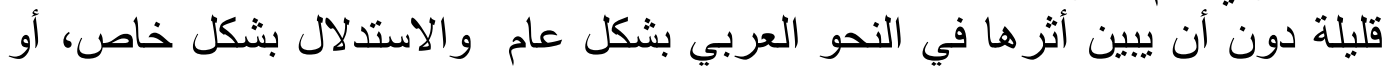

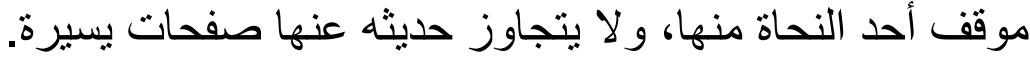

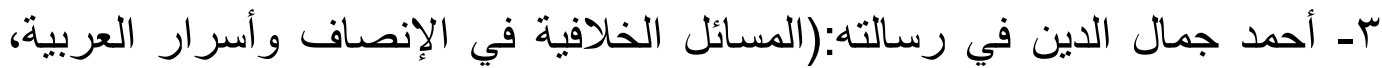

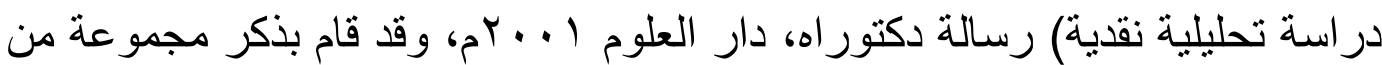

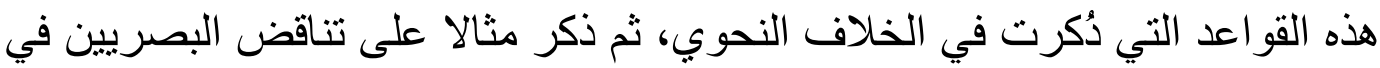
قو اعدهم، وتناقض الكوفيين فيها أيضا، دون تفصيل بذكر أو إضافة جديدة أو إلفر إبراز لموقف النحاة الصحيح من هذه القو اعد. 


\section{إشكالية|لبحث:}

تبرز إثنكالية البحث في إثارة التساؤلات الآتية نظرًا إلى العلاقة الوطيدة بين علمي أصول الفقه وأصول النحو في إنارة ـما مصدر قو اعد التوجيه عند النحاة؟

ـ هل كانت وليد فكر النحاة، وانتقلت فيما بعد إلى الأصوليين من الفقهاء أم أنها

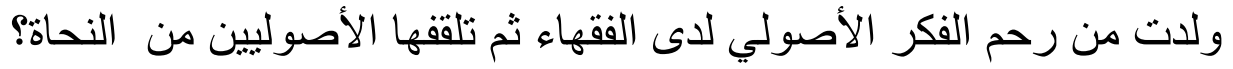

$$
\text { -ما الفرق بين قو اعد الأبواب وقو اعد التوجيه؟ }
$$

ــل العلاقة بين النحو و الفقه هي العلاقة ذاتها بين أصول الفقه و أصول النحو؟

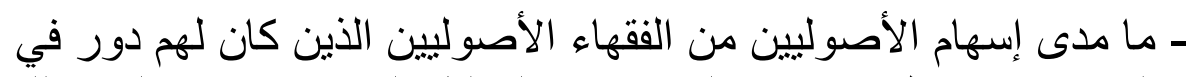
التأليف النحوي في توظيف قواعد التوجيه في التحليل النحوي و إبراز النين الفكر اللغوي 
تمهيد:

مدخل معرفي يتتاول العلاقة بين أصول الفقه وأصول النحو و أيهما أصل لخل نآخر؟

\section{بين أصول الفقّهوأصول النحو :}

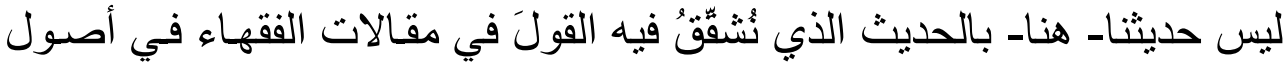

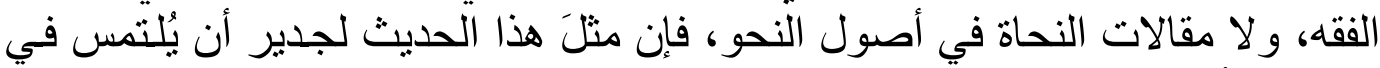
كتبه. وكلُّ ما نريده- هنا- هو إبراز صولاز اهورة التفاعل والاتصال بين هذين العلمين.

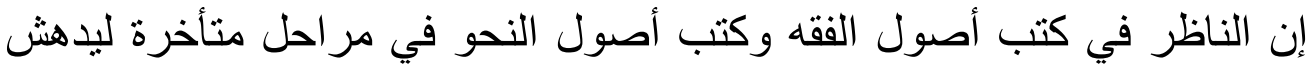

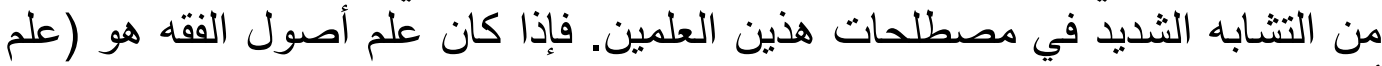
أدلة الفقه)(')، و إذا كان الققهاء قد ذهبوا في تقسيم الحكم الثر عي إلى واجب اجبٍ ومحظور ومندوب ومكروه ومباح ووضعي(٪) فكذلك ذهب النحويون في تقسيم الحكم النحوي

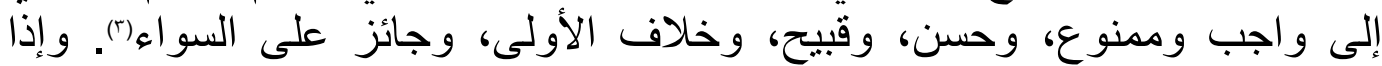

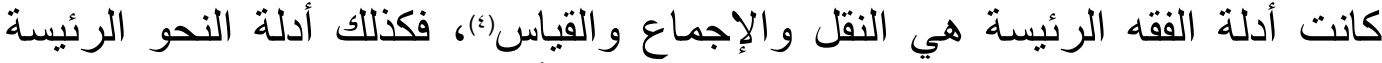
فإنها النقل والإجماع والقياس(ه). وإذا كانت هنالك أدلة فرعية في الفقه ليست محل

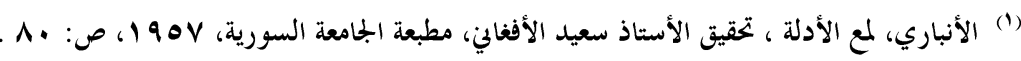

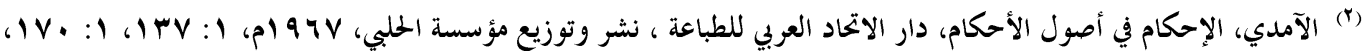
$.19 \cdot-111: 1$ 1 $1 \vee 9: 1$ 1 $1 \vee \leqslant: 1$

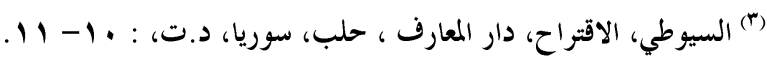

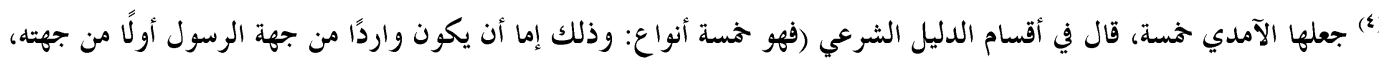

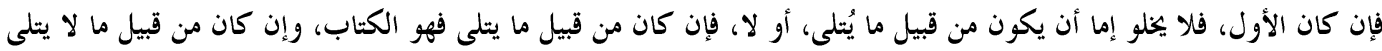

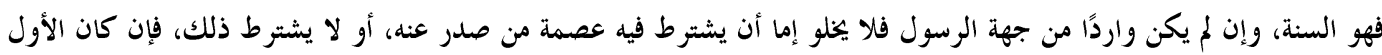

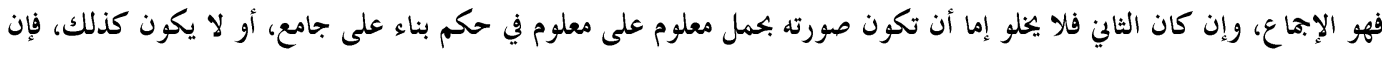

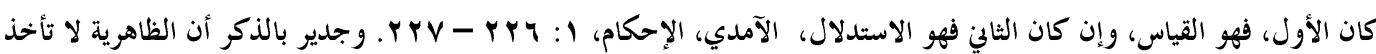

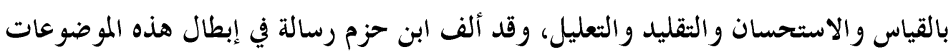

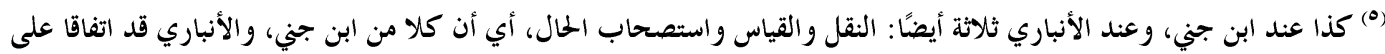

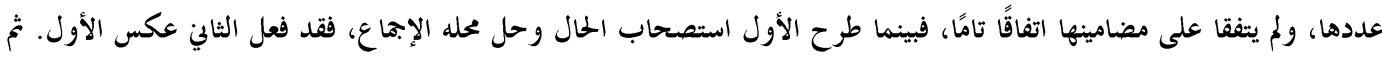

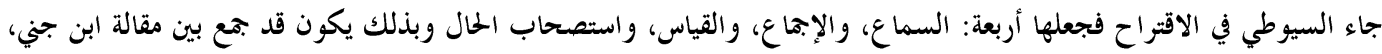


اتفاق عند الفقهاء كالاستحسان(1)، فان ثمة أدلة فرعية في النحو ليست محل اتفاق

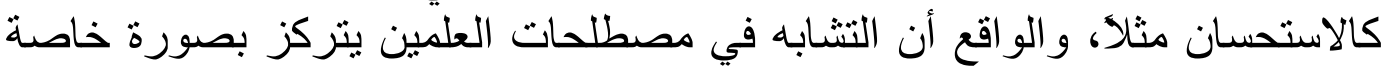

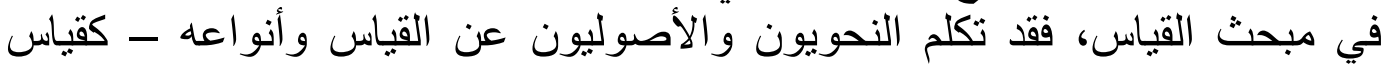

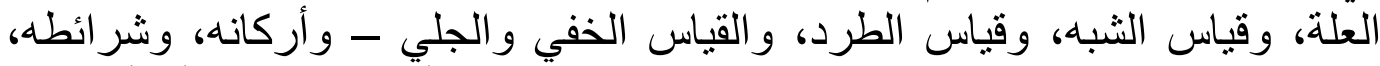

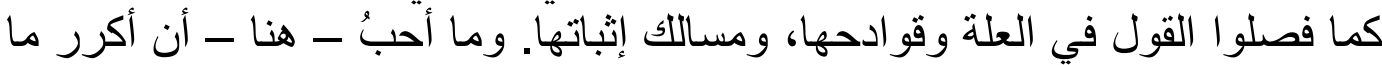

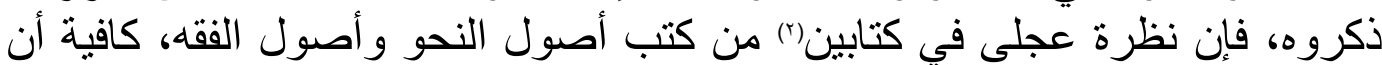

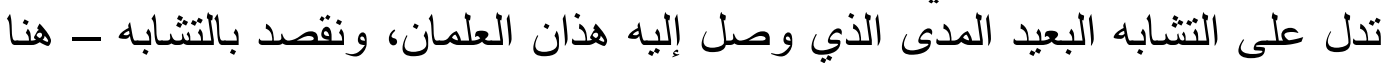

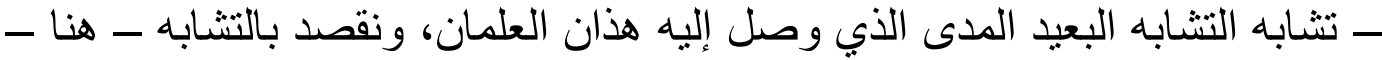

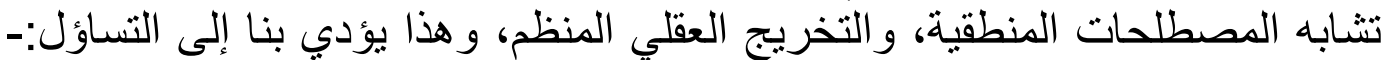

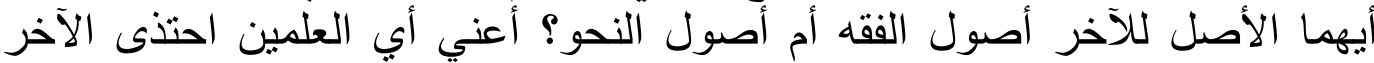

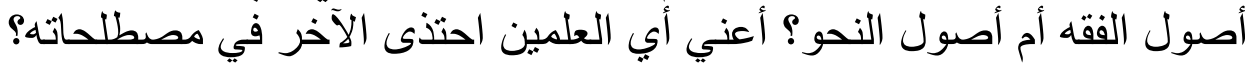

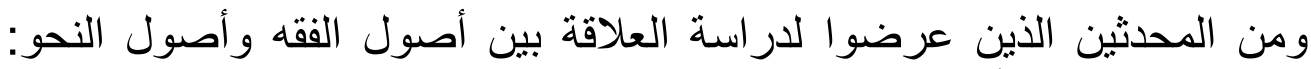

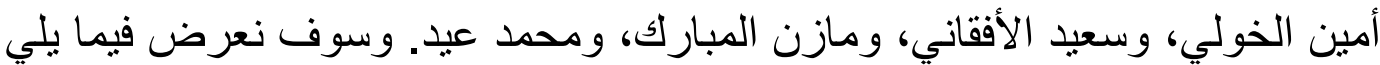
لهذه الجهود بالدر اسة و التقويخ.

\section{موقف المحدثين من قضية أصول النحو وصلتها بأصول الفقه:}

أوَّلُ ما نذكر من المحدثين الأستاذ/أمين الخولي، فهو يعتقد أن أصول النحو محمولة

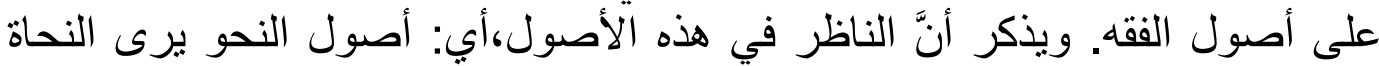

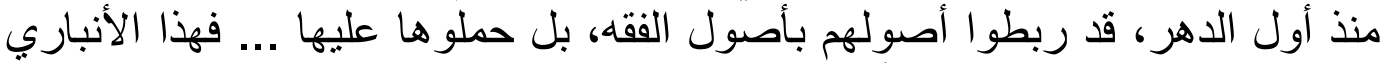

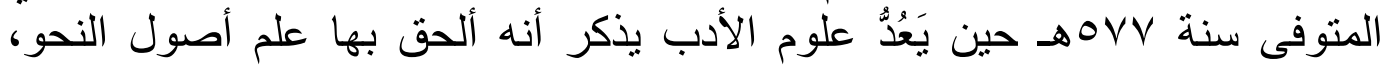

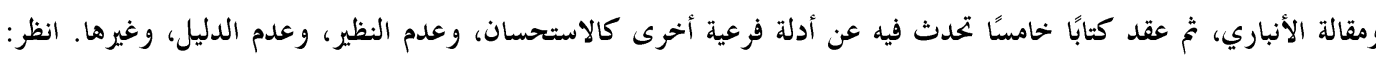

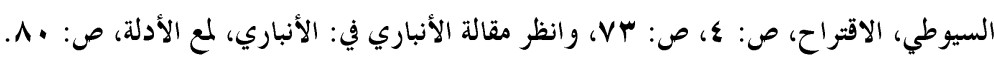

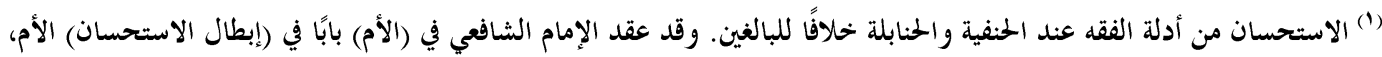

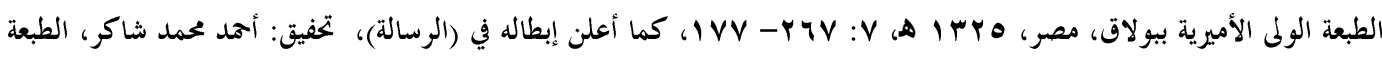

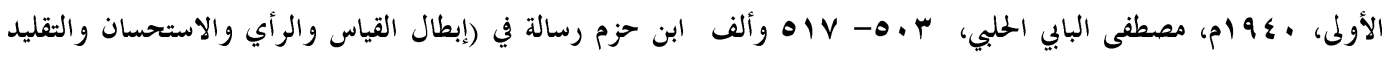

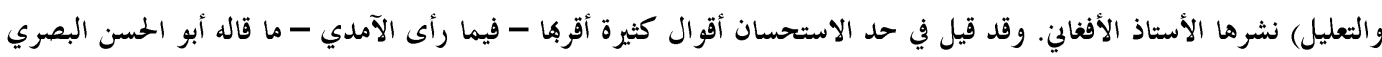

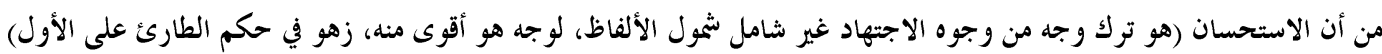

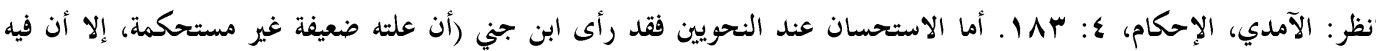

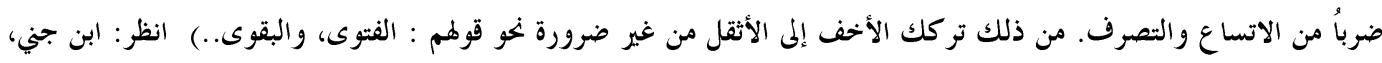

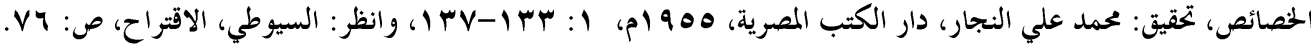

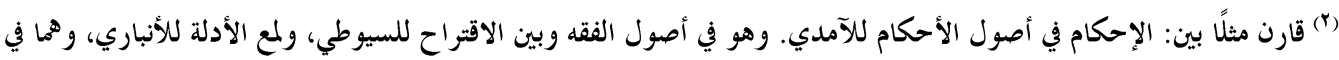


قُيُعْرَفْ به القياس، وتركيبه، و أقسامه، من قياس العلة، وقياس الثببه، وقياس الطرد،

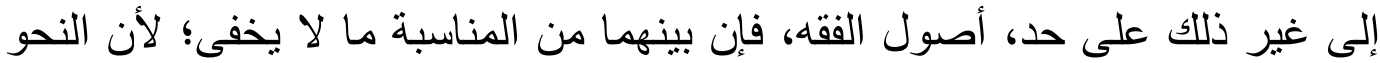

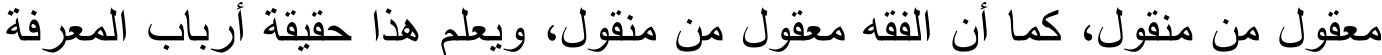

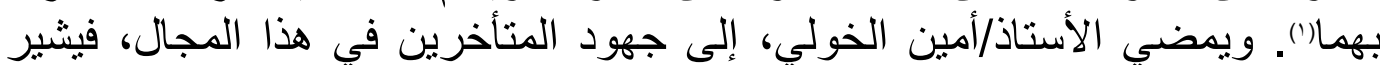

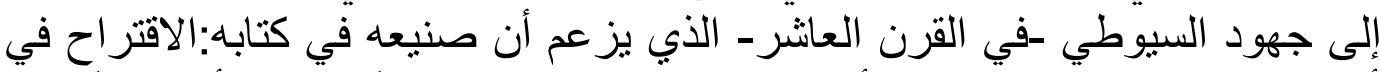

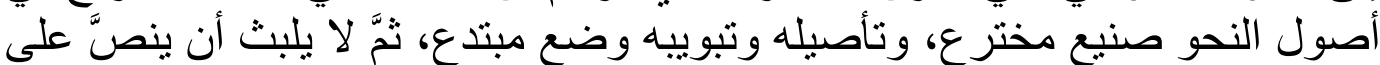

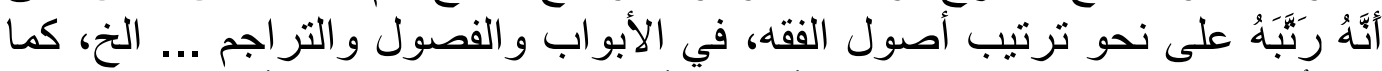

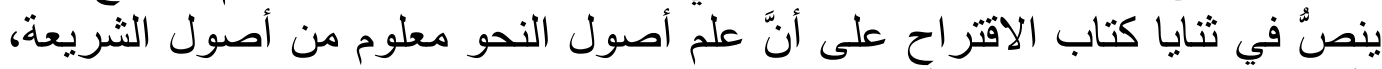

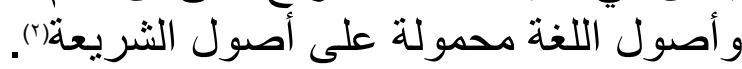

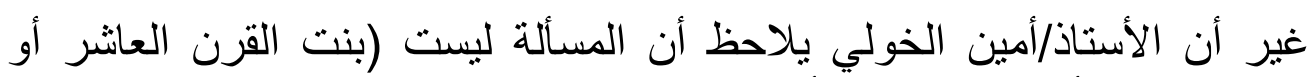

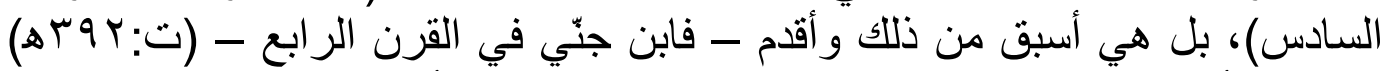

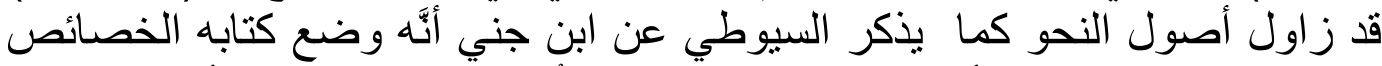

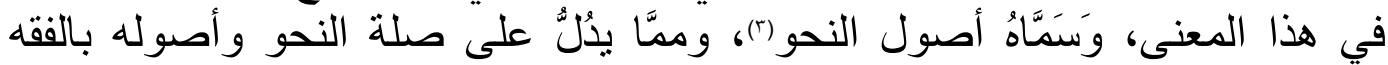

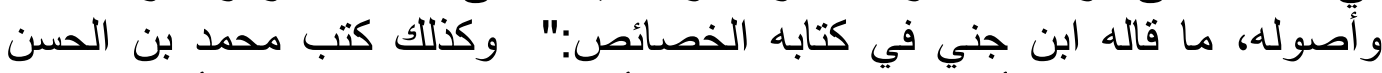

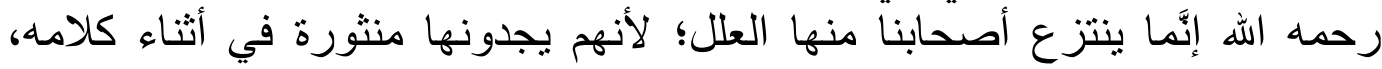

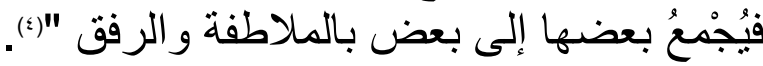

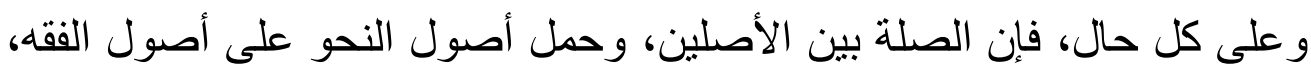

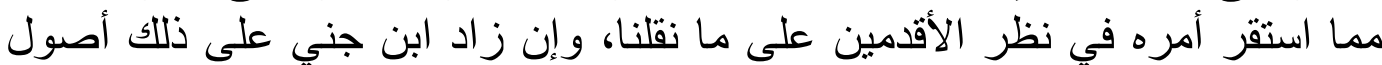

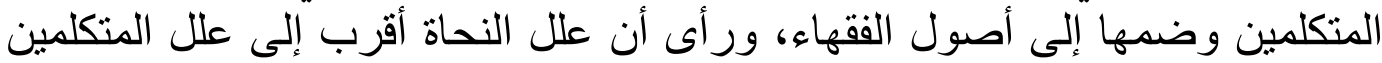

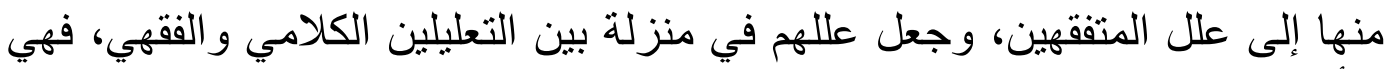

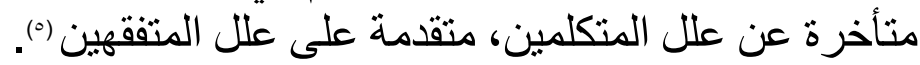

وأول ما نلاحظه في كلام الأستاذ/الخولي أن أصول النحو محمولة على أصول الفقه

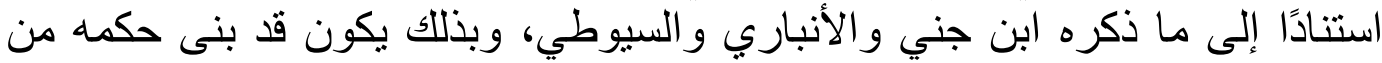

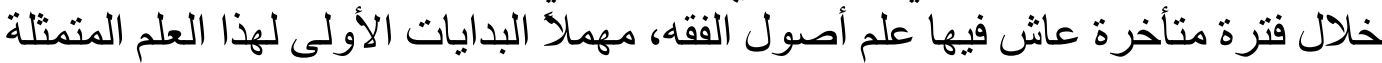

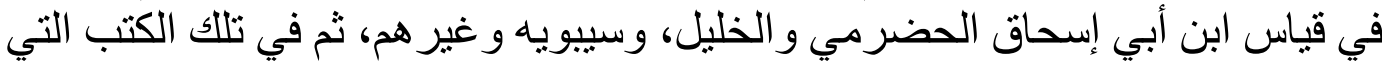

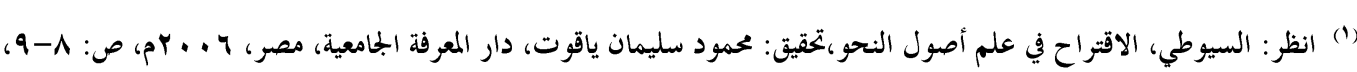

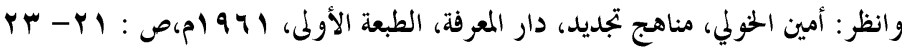

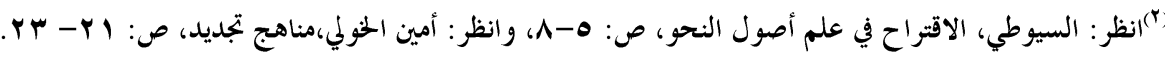

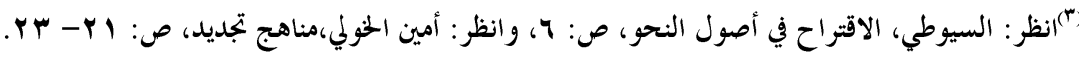

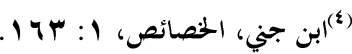

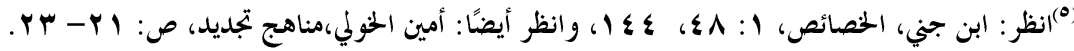


ألفت للبحث في العلل النحوية كما أن الأستاذ نظر في أصول الفقه من خلال فترة

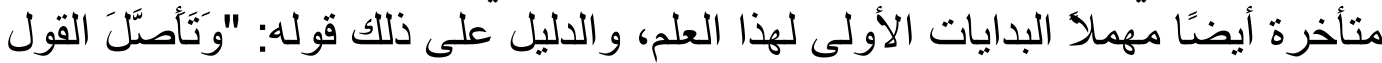

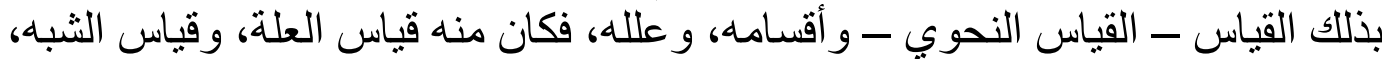

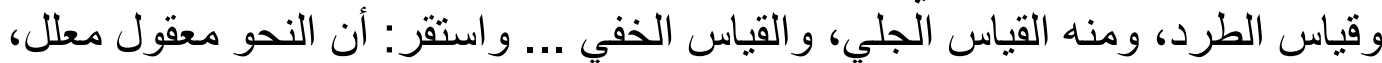

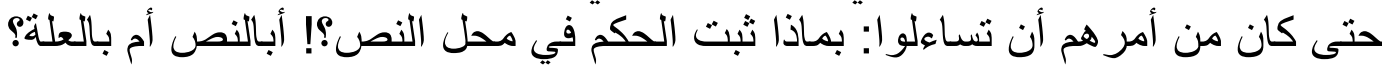

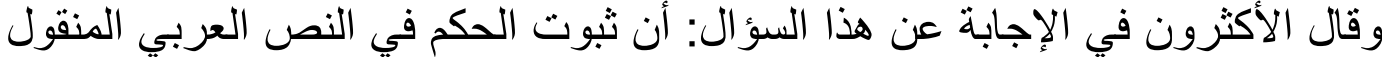

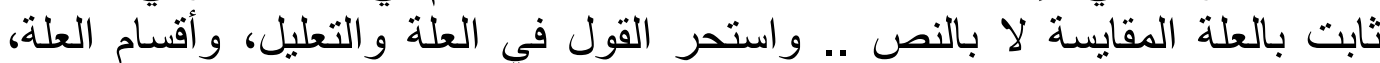

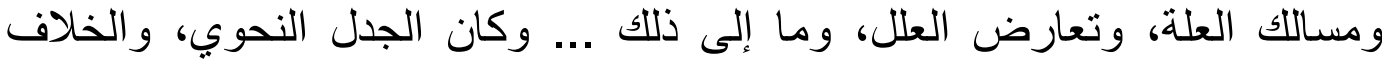

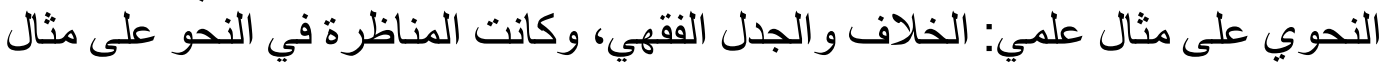
المناظرة في الفقه .. و هكذا فهمو ا طبيعة اللغة، وفهمو ا طبيعة العمل النحوي" (').

فهذه المباحث الششتركة بين النحويين و الأصوليين التي ذكر ها الأستاذ إنما تمت في

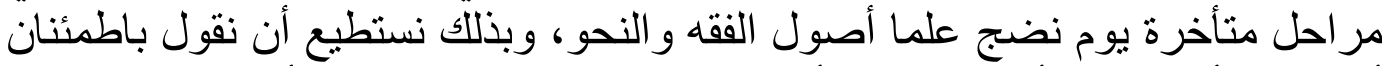

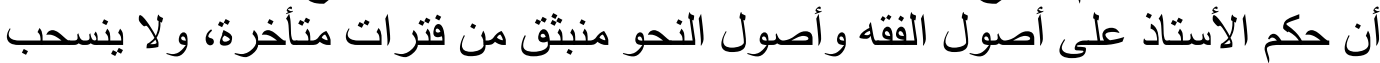

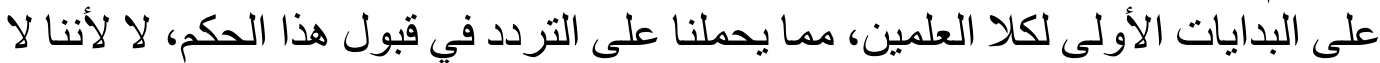

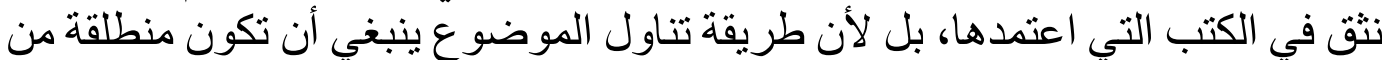

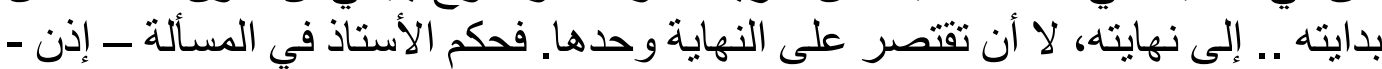

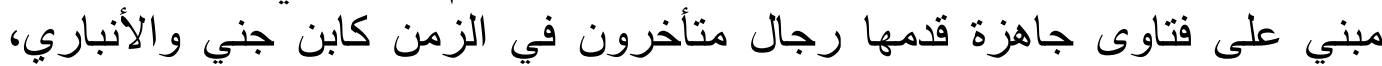

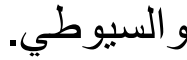

ومهما يكن من أمر فإن أصول النحو - عند الأستاذ ـ محمولة على أصول الفقهاه

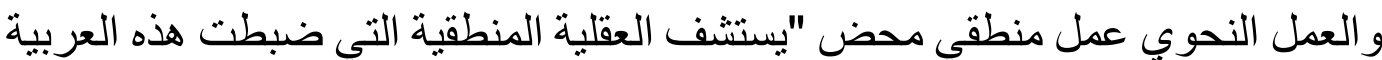

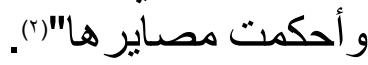

و إذا تجاوزنا الأستاذ/الخولي إلى الأستاذ/الأفغاني، وجدناه لا يختلف عن الأني الأول في

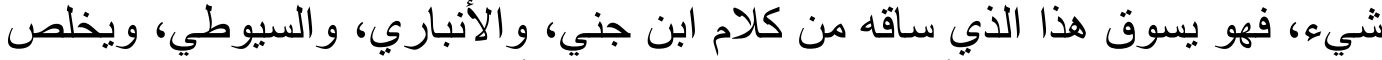

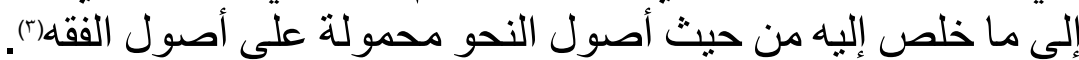

أمَّا الدكتور/مازن المبارك فإنه يميل إلى تفتيت هيكل أصول النحو المتماسك،

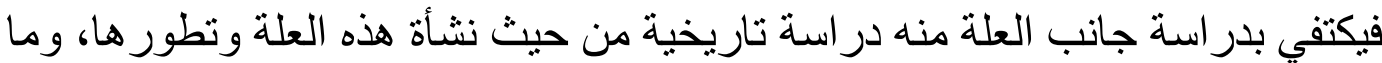

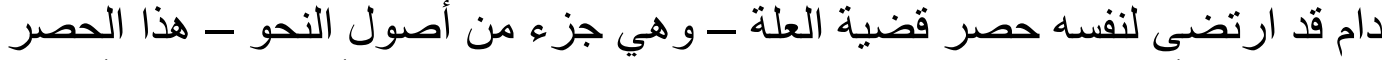
الضيق، فقد أر اح نفسه من الدراسة، المفصلة للصلة الوثيقة بين أصول النحو و أصول الصول

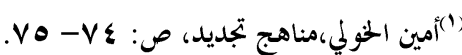

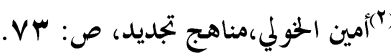

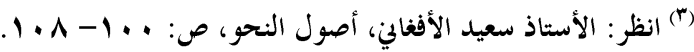


الفقه، وكذلك لم يعرض للإجابة عن السؤال الهام، أيهما الأصل للآخر أصول الفقه أم أم أمري

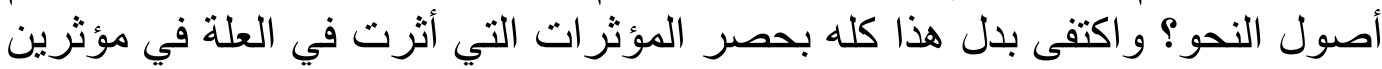

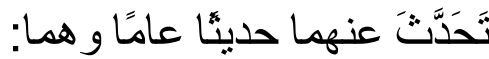

1 - النزعة المنطقية التي تسربت إلى النحو عن طريق المتكلمين.

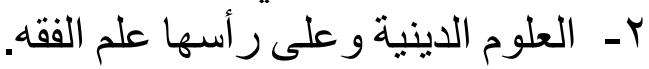

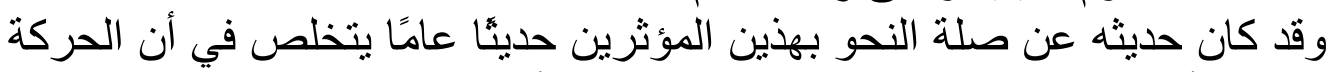

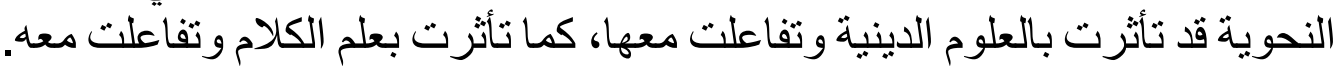

أما السؤال الكبير الذي أوردناه والذي يتعلق بالصلة بين أصول الفقه وأصول النحو

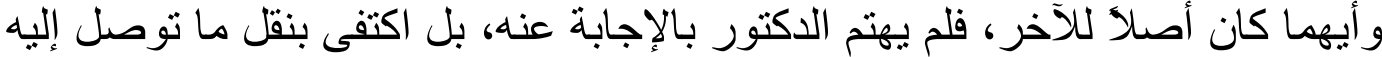

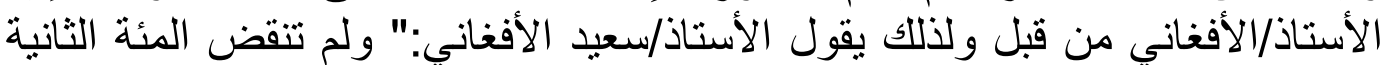

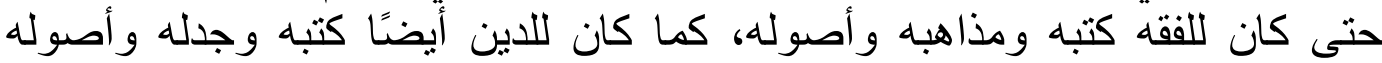

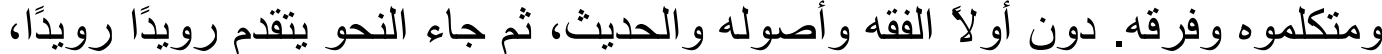

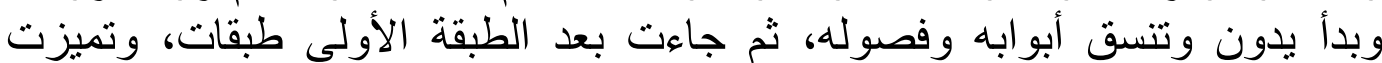

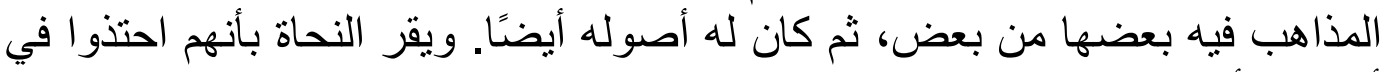

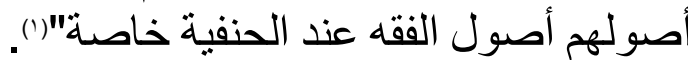

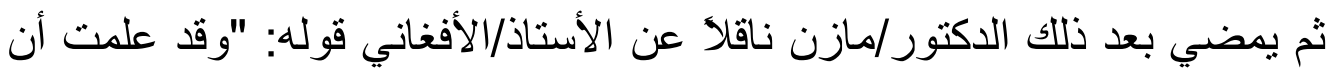

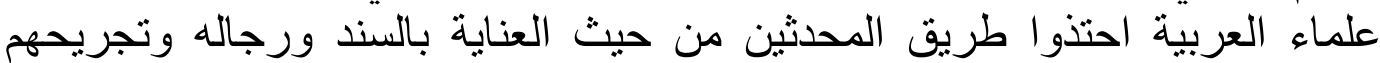

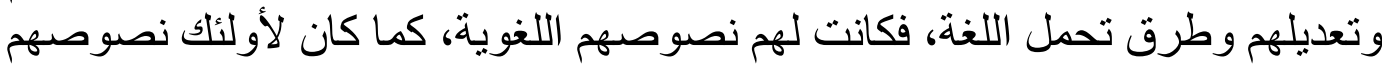

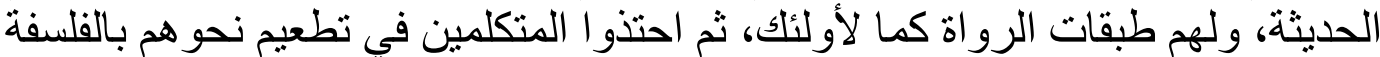

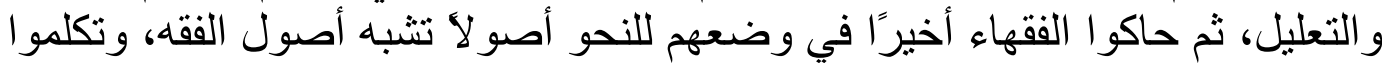

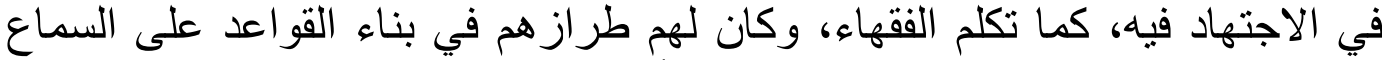

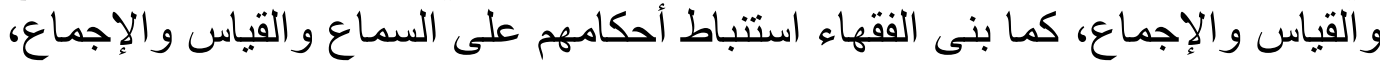
وذللك أثر واضح من آثار العلوم الدينية في علوم اللغة" (r).

فالدكتور/المبارك إذن يتبنى وجهة نظر الأستاذ/الأفغاني القائلة بأن أصول النحو

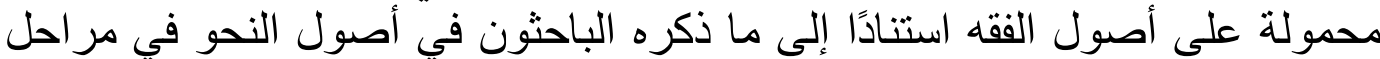

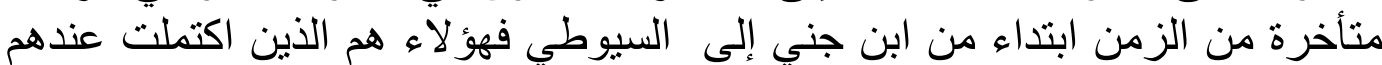

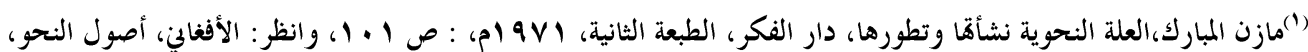

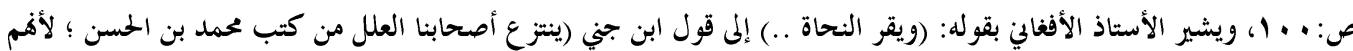

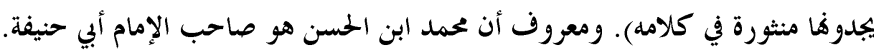

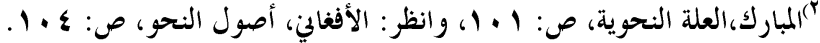


أصول النحو من سماع وقياس و إجماع على نحو ماصنع الفقاء القاء في في أصول الفقه، و هذا هو ما أنشار إليه الأستاذ/الأفغاني في النص السابق ذاعل ذكره.

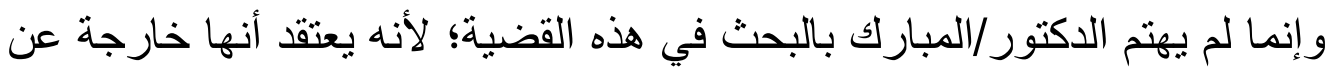

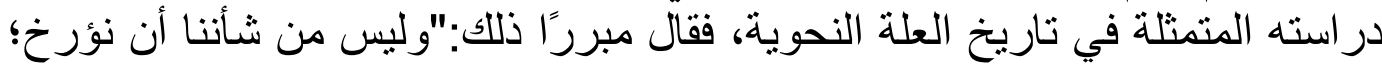

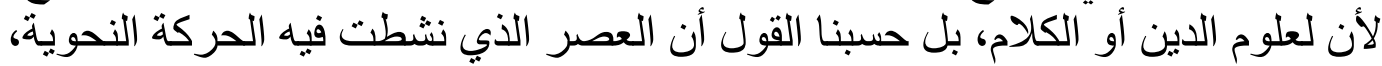

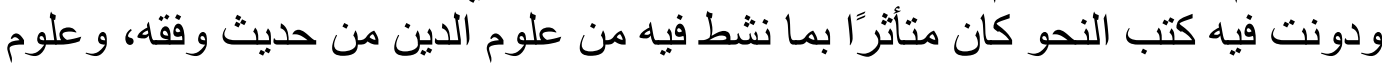

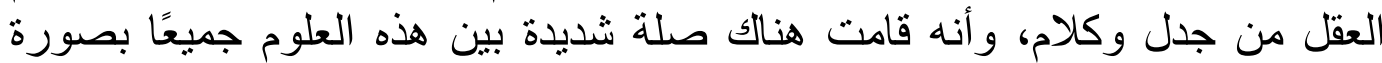

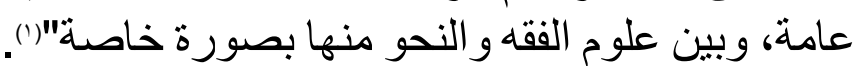

ثم يقول في موضع آخر : "وليس يعنينا أن نتحدث عن هذه الصلة بين النحو و وعلوم

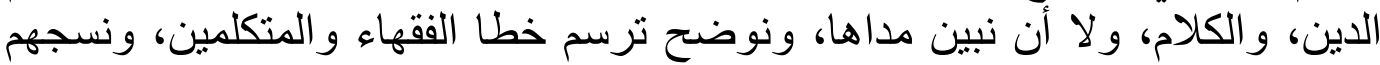

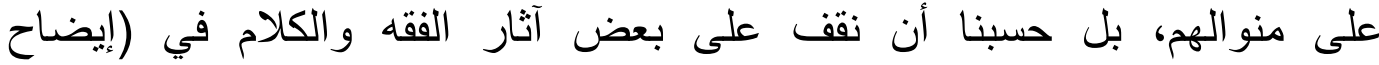

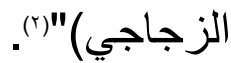

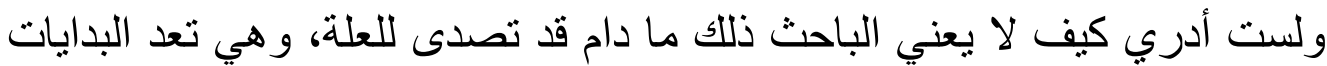

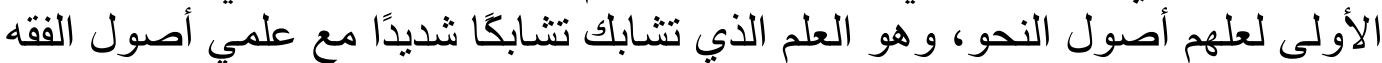

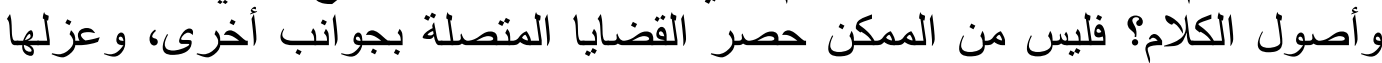

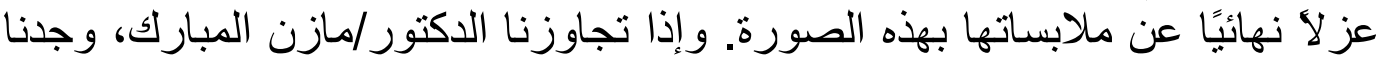

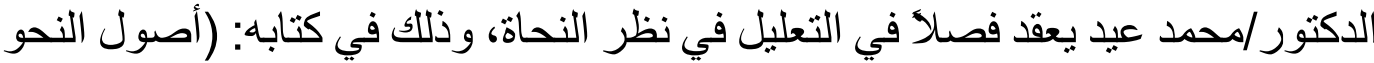

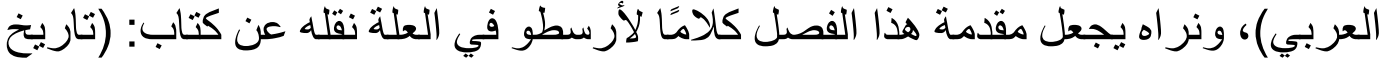

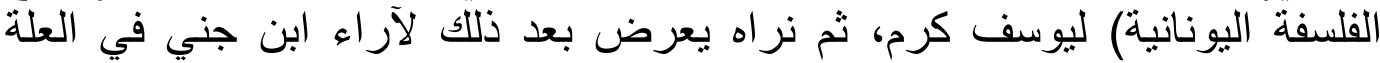

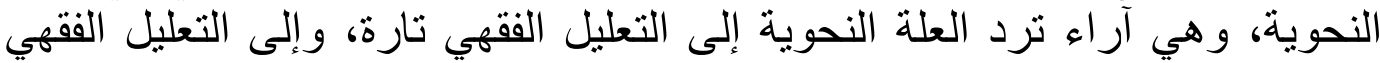

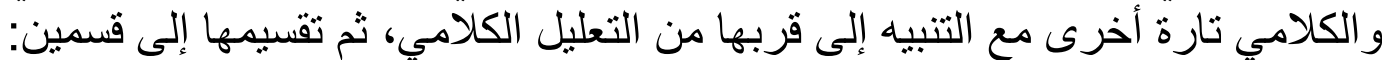

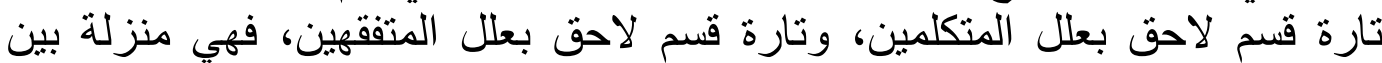

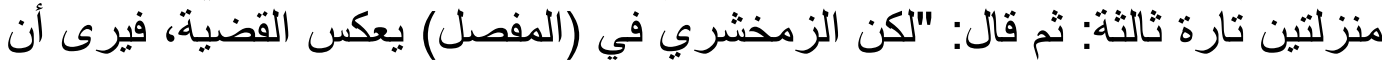

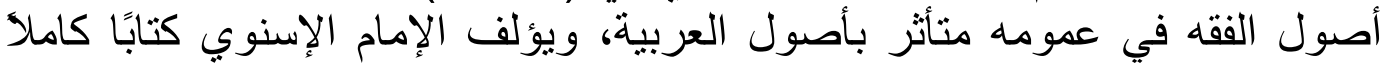

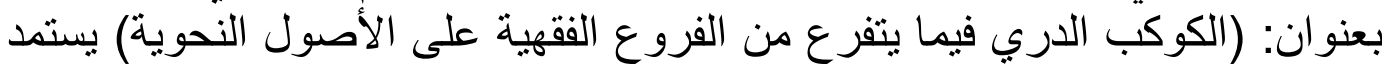

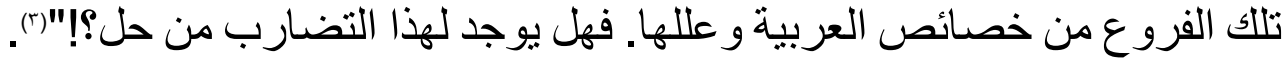

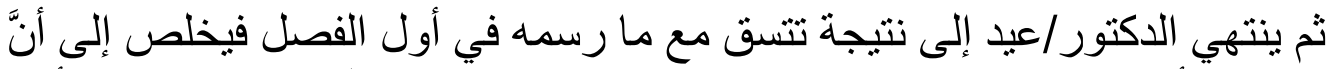
التعليل قد بدأ في النحو سابقًا لكل من الفقه و وعلم الكلام، وقد نَسَرَّبَ التعليل إليه متأثرًا

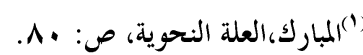

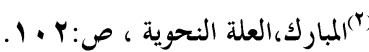

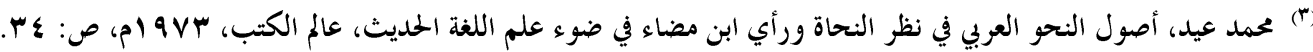




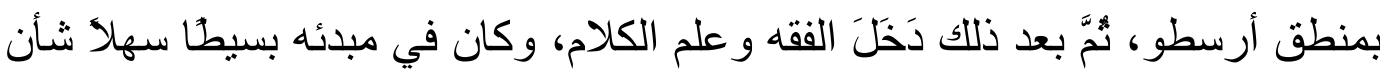

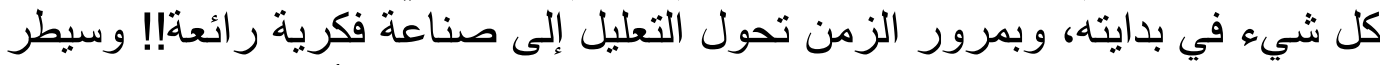

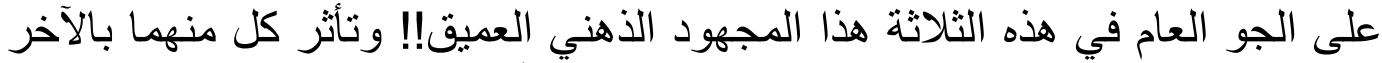

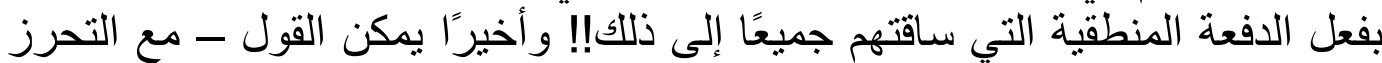

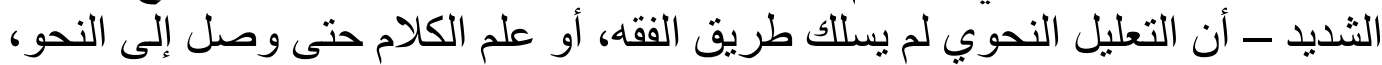

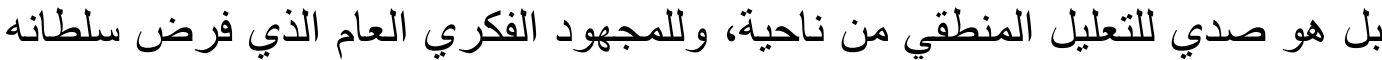
على الباحثين في الدين و اللغة فيما بعد (1).

وواضح من هذا الذي ساقه الدكتور/عبد إهماله للبدايات الأولية لكل من علمي

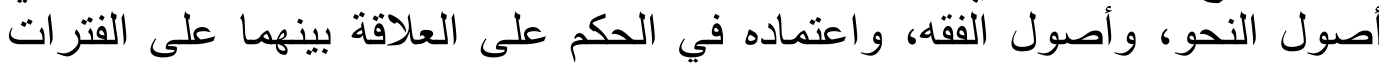

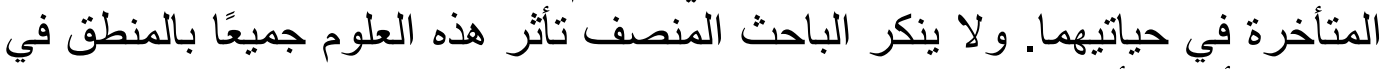

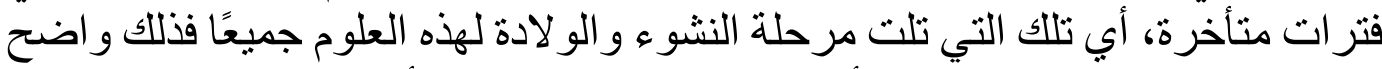

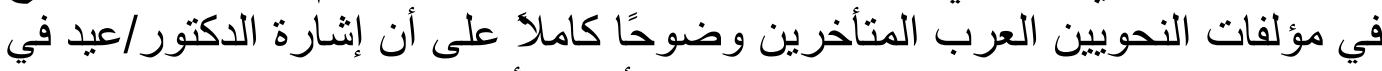

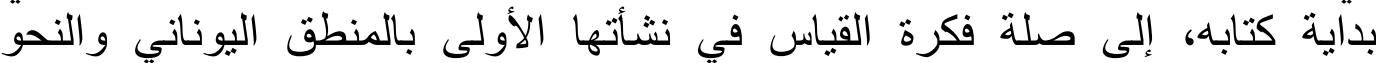

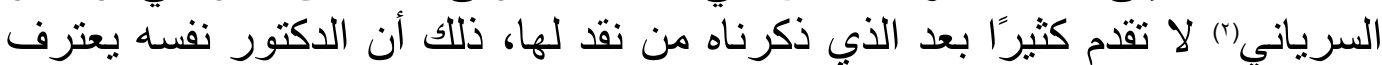

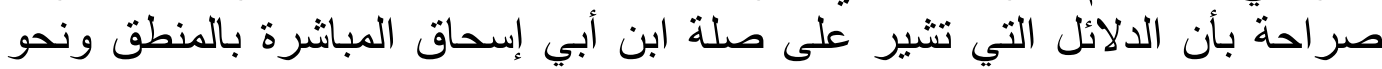

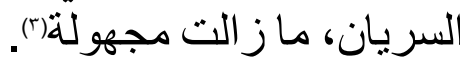

و عليه فلا نستطيع أن نقول مع الدكتور /عيد إن المنطق في النحو سابق لكل من الفقه

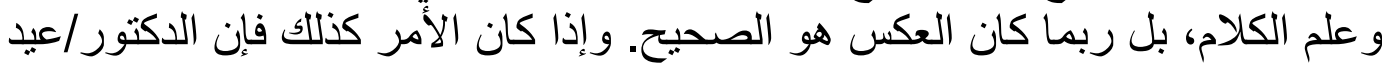

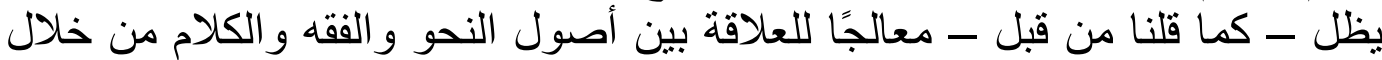

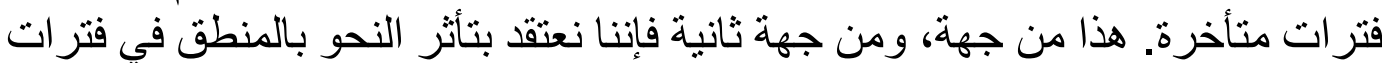

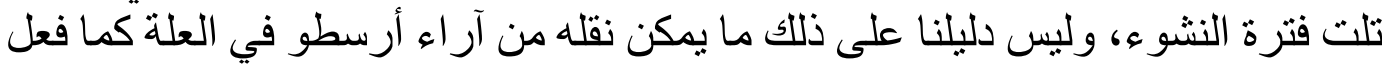

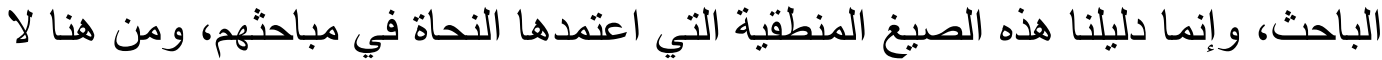

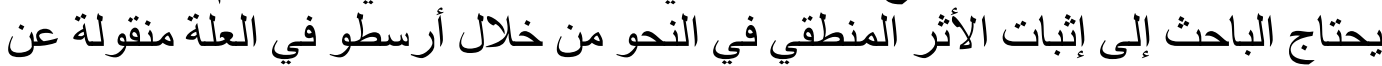
أرسطو.

ومن جهة ثالثة: فإن الدكتور /عيد حين عرض لآر اء ابن جني في العلة، استنبط منها

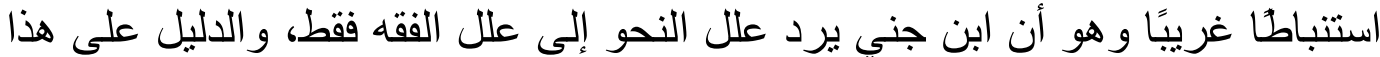

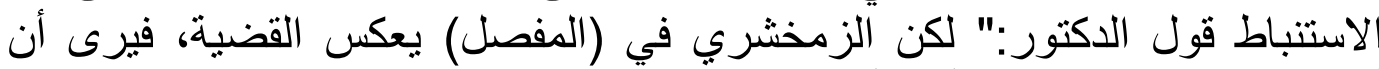
أصول الققه في عمومه متأثر بأصول العربن العربية" وما دام الزمخشري قد عكس القضية،

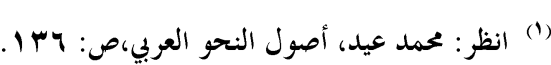

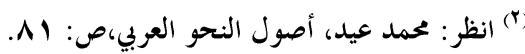

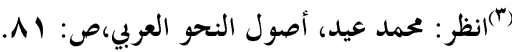


فابن جني - إذن - هو الذي قال بتأثر أصول النحو بأصول الفقه. وهذا خطأ بين؛ لأن

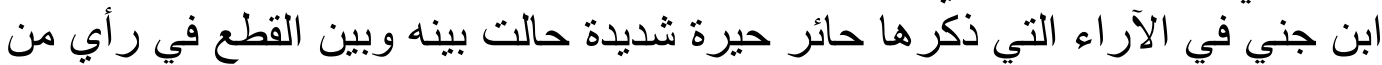

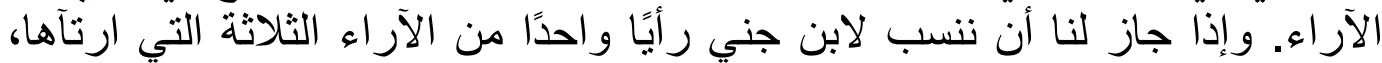

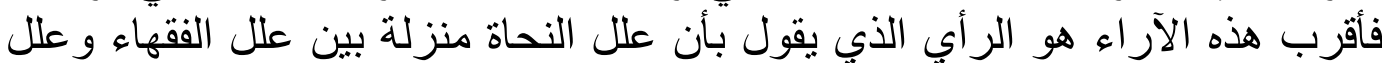

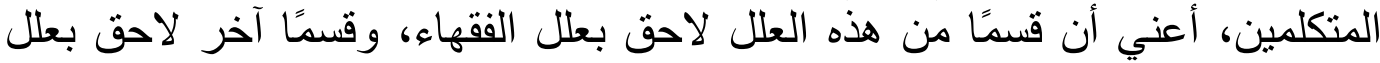

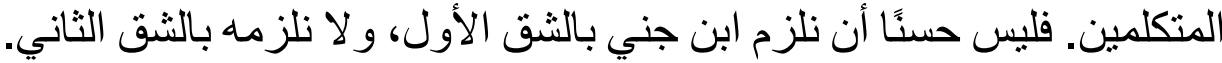

ومن جهة رابعة فإن ما ذكره الدكتور /عيد من أن الزمخشري في (المفصل) و الإمام

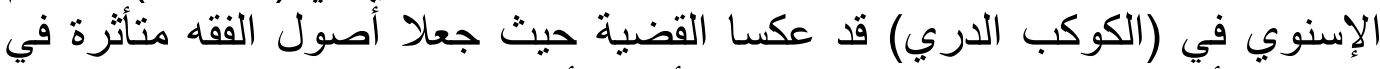

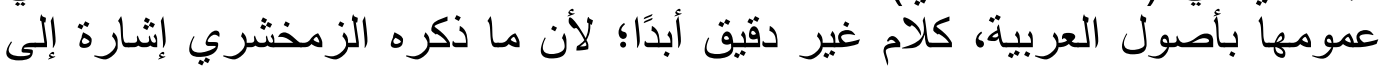

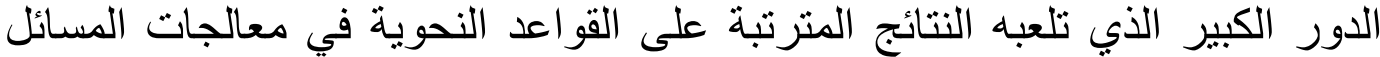

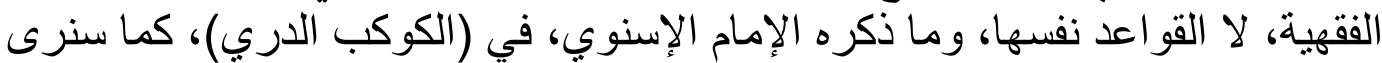

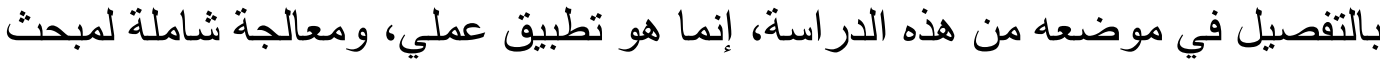

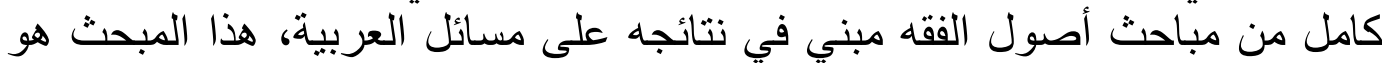

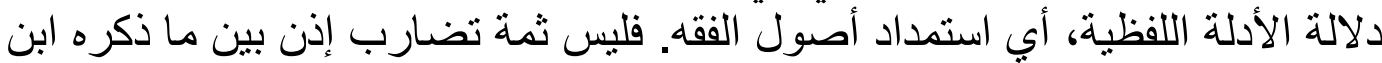

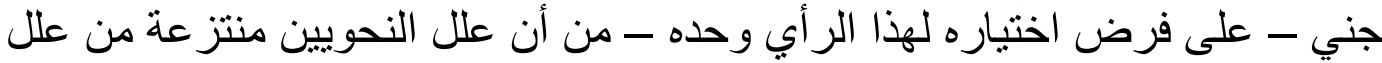

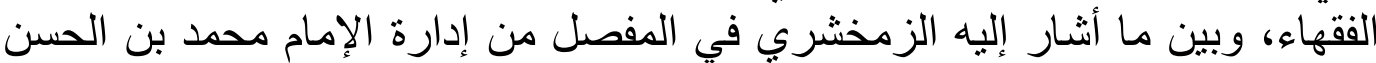

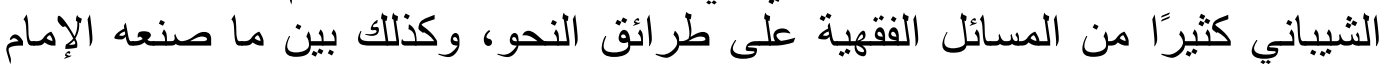
الإسنوي في كتابه: (الكوكب الدرياني الفئ.

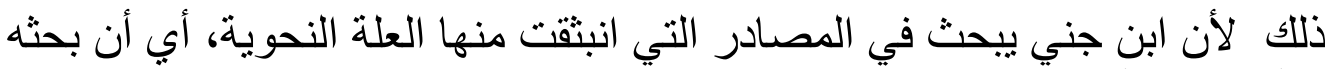

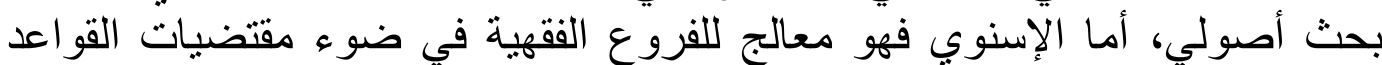

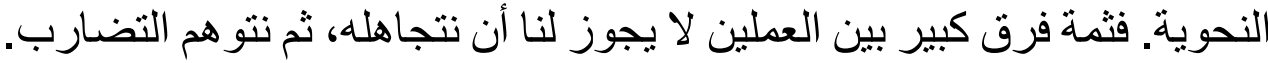

فأما حل هذا التضارب الموهوم فهو ـ كما بيناه فيما مضى ــ، أن نفرق بين لونين

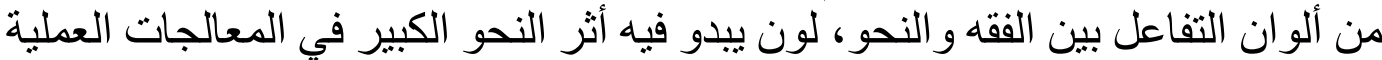

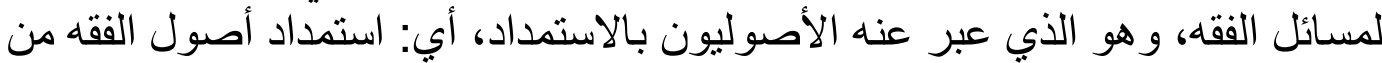

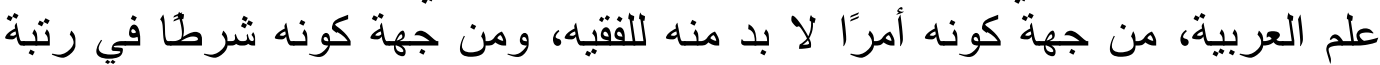

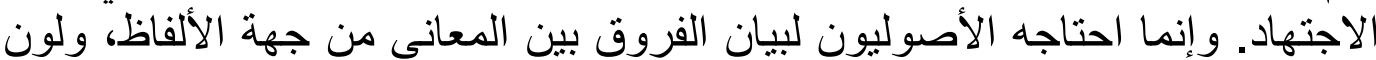

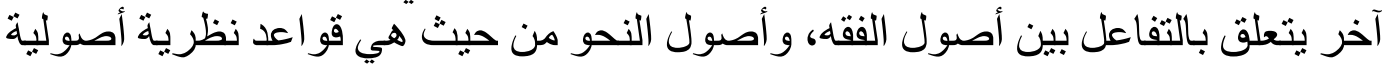

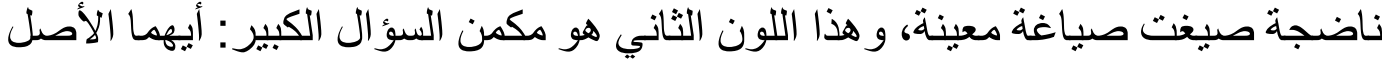
لملآخر أصول الفقه أم أصول النحو؟.

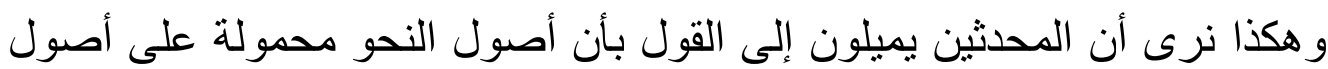

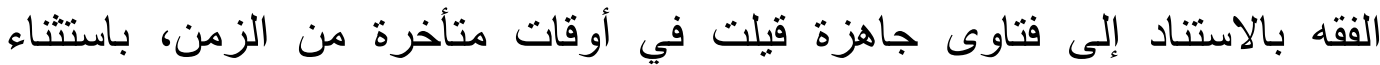


الدكتور/عيد الذي يرى أن التفاعل بين العلمين كان في إطار المنطق الذي جمع بينهما، وأن المنطق في النحو سابق. لكل من علمي الفقه و الكلاّ.

ونحن نعتقد أن الحكم على العلاقة بين أصول الفقه، وأصول النحو لا يتأتى إلا بعد النظر في البدايات الأولى لهذين العلمين.

فأما البدايات الأولى لعلم أصول النحو، فإنها ترجع إلى القرن الثناني الهجري كما

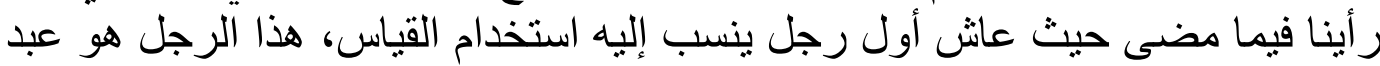

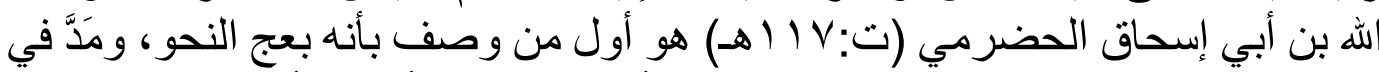

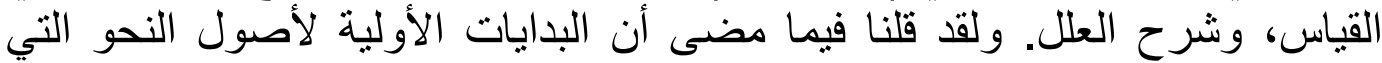

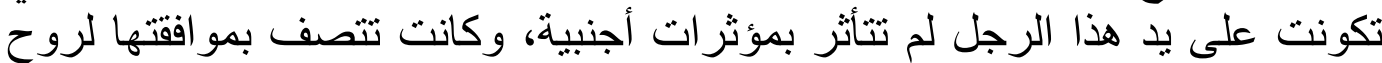
اللغة، وطبيعة الكلام العربي، وقلنا أيضًا إن هذه البرات البدايات قد اتسعت بعد ذللك، ومرت

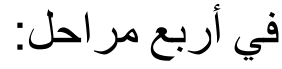

ا - مرحلة التأليف في العلل النحوية. r- مرحلة ظهور (مصطلح) أصول النحو. مرئ بـ مرحلة الإشار ات الأولى إلى الصلة بين أصول الفقه و الكلام و أصول النحو.

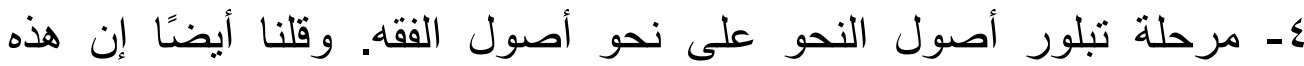

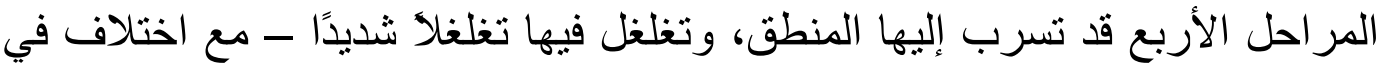

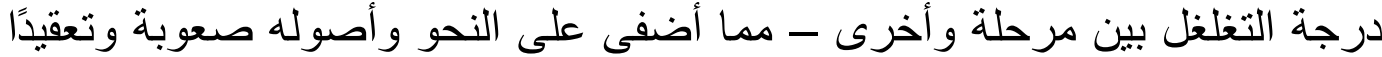
بالغين.

على أنه من المكن أيضًا أن تكثف هذه المراحل من حيث علاقة النحو بالمنطق و أصول الفقه في ثلاث مراحل على النئًا النحو التالي: ا - مرحلة البدايات الأولى لعلم أصول النحو. r- برحلة تغلغل المنطق في هذا العله. r- مرحلة اتصال أصول النحو بأصول الفقه، واستفادتها من طرائق ترتيب

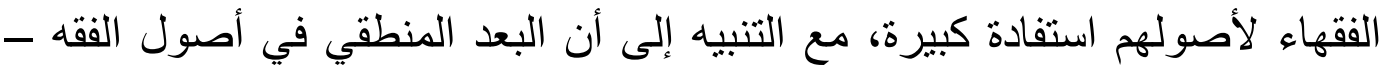

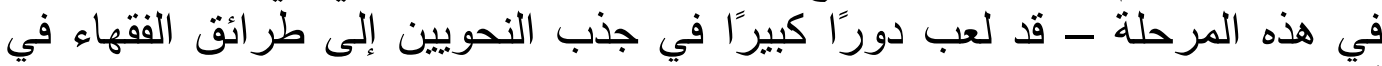

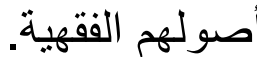


هذا عن البدايات الأولى لعلم أصول النحو، وما طر أ على هذه البدايات من تطور

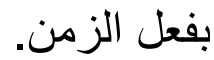

فأما أصول الفقه فقد سارت في تاريخها الطويل ـ على ما نظن - في ثلاث مر احل: - 20 - n

ا- المرحلة الأولى: وتثتنمل على البدايات الأولية لعلم أصول الفقه ابتداء من

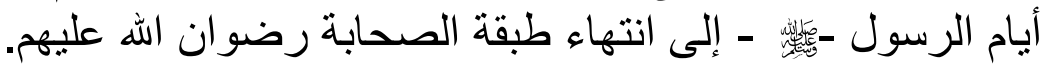

r ـ المرحلة الثانية: مرحلة التابعين ومن تلاهم إلى أن نصل إلى الأئمة الأربعة،

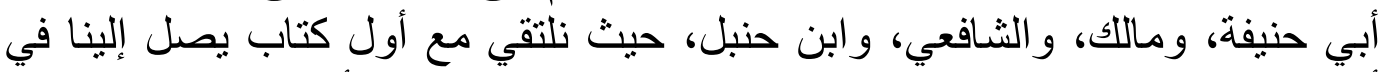

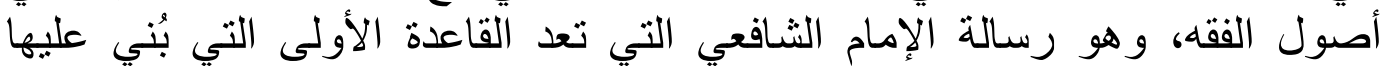
التأليف في علم أصول الفقه فيما بعد").

r- المرحلة الثالثة: مرحلة نضوج أصول الفقه و اكتمالها، وذللك واضح في الجهود التالية لرسالة الثافعي.

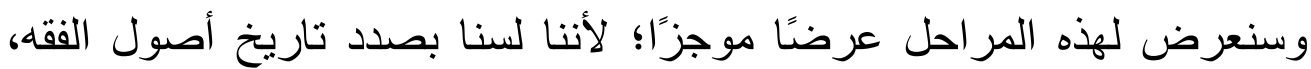

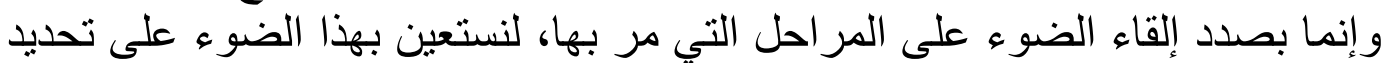
شكل العلاقة بين علمي أصول النحو وأصول الفقاه.

هذه هي الملامح العامة التي مر بها كل من علم أصول النحو و أصول الفقه.

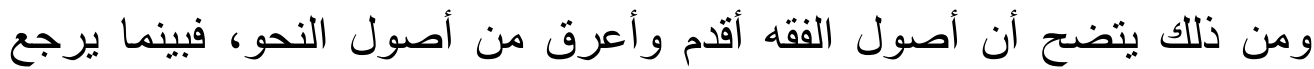

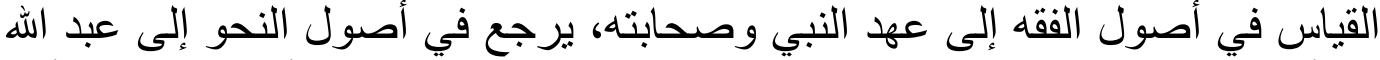

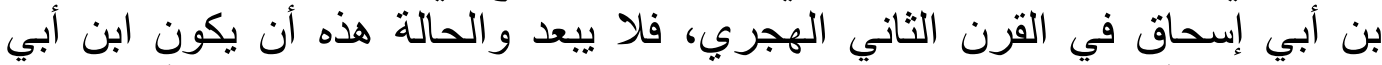

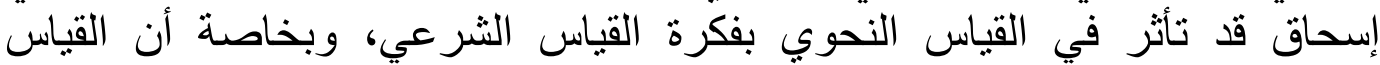

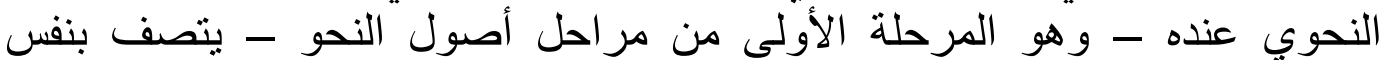

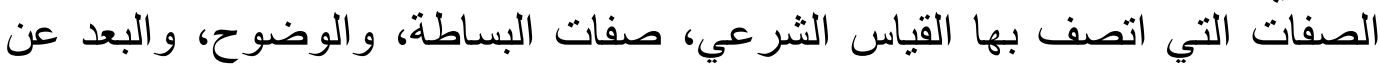

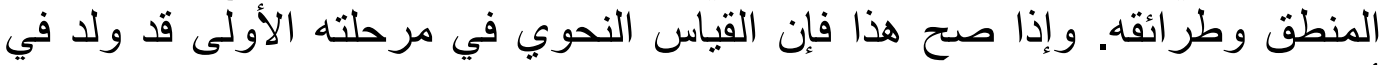

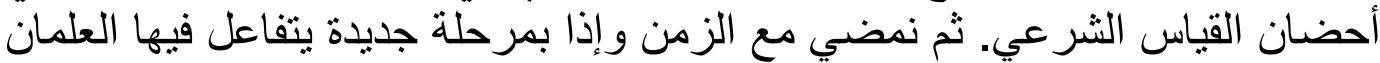

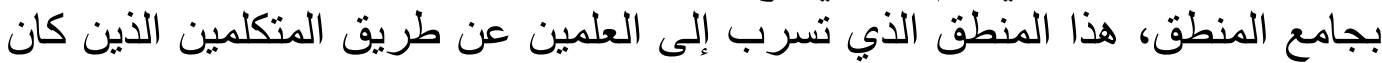

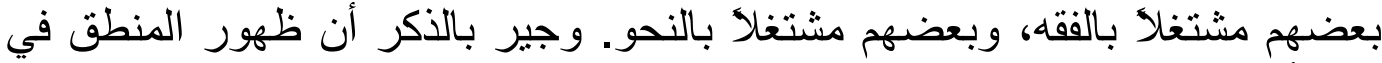

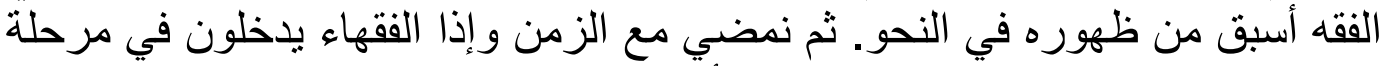

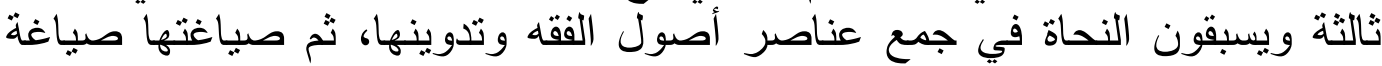


منطقية بحتة، ويأتي النحاة من بعدهم فيحتذون حذو هم في وضع أصولة لهم النحوية في نفس الإطار المنطقي، وأوضح صنئ صورة لهذا العمل منثنّلة في كتاب: (لمع الأدلة) لنأنباري.

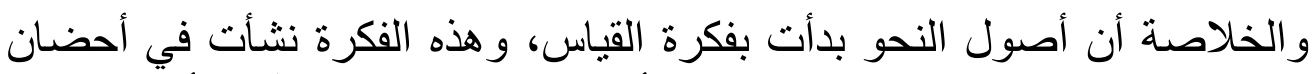

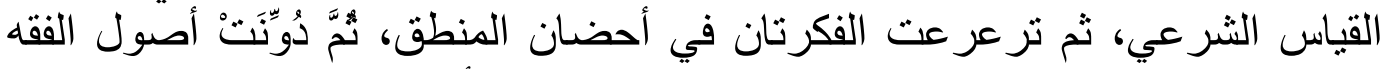

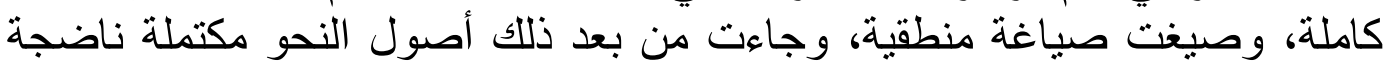
في إطار منطقي على نحو أصول الفقه تمامًا.

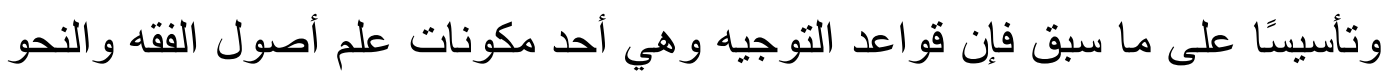

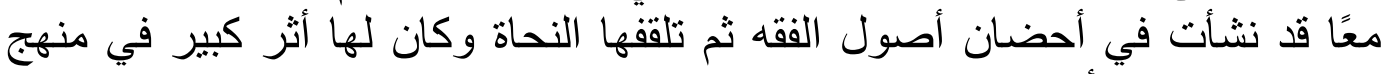
التفكير النحوي للأصوليين من النحان. 


$$
\begin{aligned}
& \text { المبحث الأول: قو اعد التوجيه في النحو العربي، } \\
& \text { ويشمل: } \\
& \text { أولاً: معنى الوجه لنةقواصطلاحًا } \\
& \text { ثانيًا: معطلحقواعد الوجيه بين القديموالحديث } \\
& \text { ثلثًا :مكانةقواعد الوجيه بين الأصول النحوية }
\end{aligned}
$$

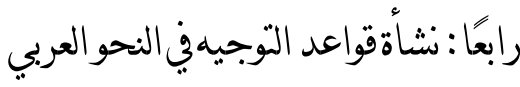

$$
\begin{aligned}
& \text { خامسًا: مصادر قواعد التوجيه عند النحاةوصياغتها }
\end{aligned}
$$

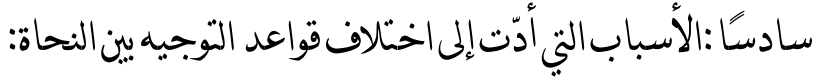


أولاً: معنى الوجه لفةً واصطلاحًا:

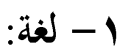

قبل الدخول في التعريف الاصطلاحي علينا أن نذكر أولا معنى التوجيه لغويا،

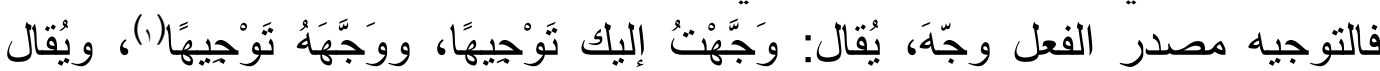

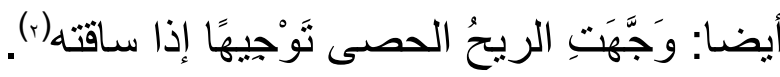
و الوجه في الكلام السبيل الذي تقصده به(r)، فقولنا: وجَّةَ الكلامَ توجيهًا، أبي اتُجه به

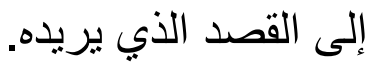

وترد أيضا في المعاجم اللغوية بمعنى الجهة،والناحية، وصرف الكلام عن وجهاه وفها،

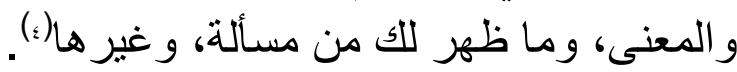

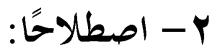
نتناول في بيانتا للمعنى الاصطلا: اصحي للتوجيه أمرين مهمين: الأول: الأصل الذي أخذ منه لفظ التوجيه، وهو لفظ الوجه. الثاني: التوجيه نفسه الذي يمثل العملية النحوية التي يقوم بها النحاة.

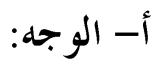

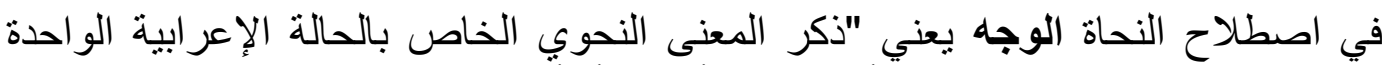

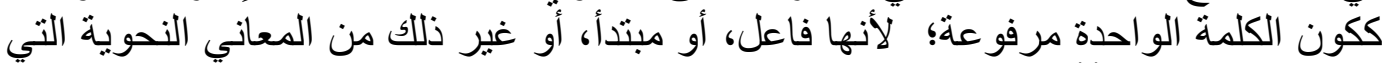
يكون عليها الرفع "(م).).

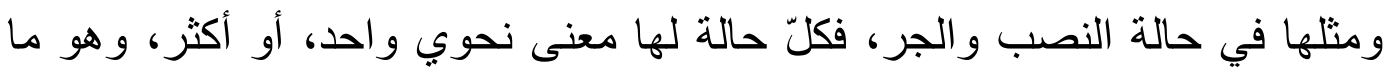
يُبسمى بالوظيفة النحوية أيضا.

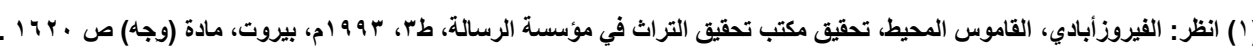

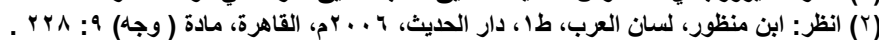

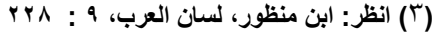




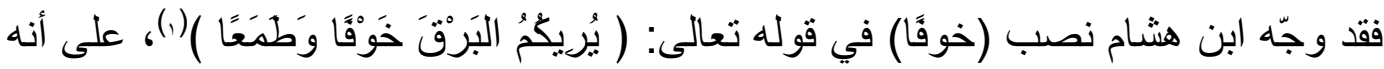
مفعول لأجله أو مفعول مطلق، أو حال(r).

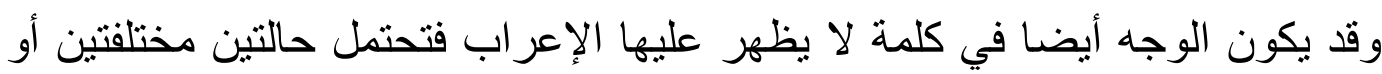
أكثر، فبذلك بتناول الوجه لا المحل الإعرابي الواحد فقط، بل أكثر من محل، وما لإسا

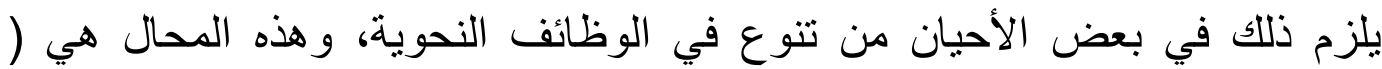

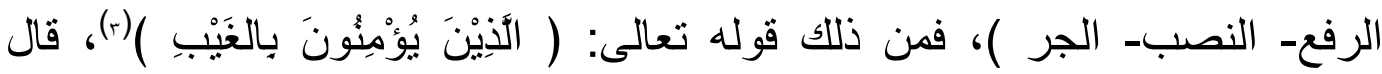

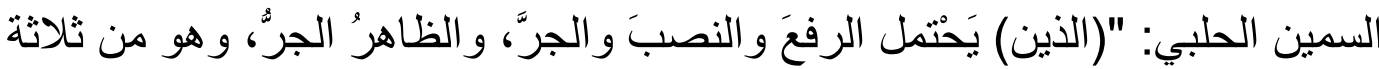

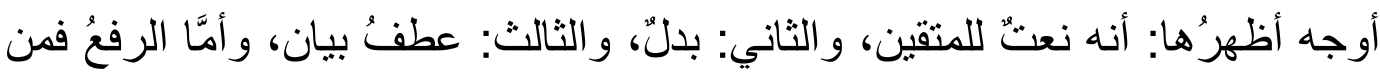

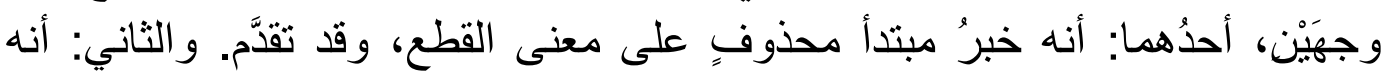

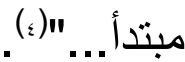

فترى هنا أكثر من توجيه لكلمة (الذين)، وهذا التوجيه لا يقتصر على حالة إعرابية

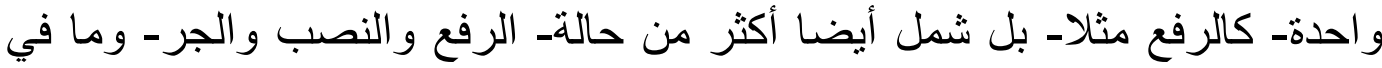
كل حالة من وظيفة نحوية تختلف عن الرفل الأخرى.

والوجه بهذا المعنى يمكن أن نطلق عليه اسم الوجه الإعرابي؛ لأنه متعلق

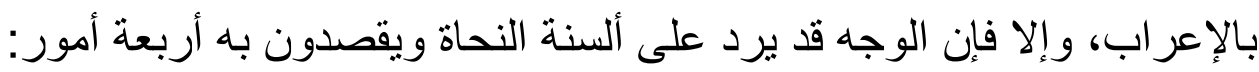

الأول: يراد به أصل الكلام، فمن ذلك قول سيبويه في قولهم:وما كل من و افى منى أنا

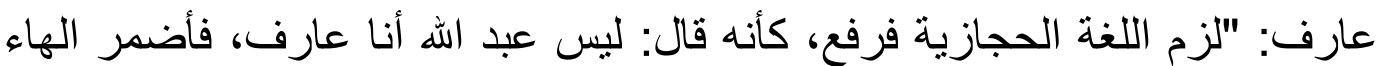

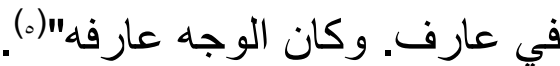

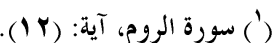

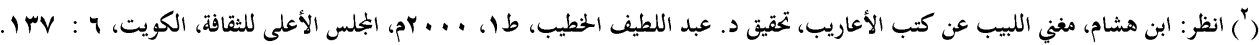

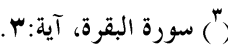

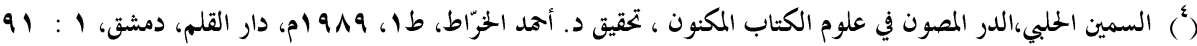

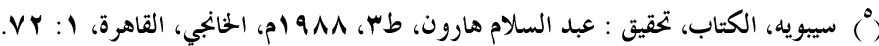


الثاني: يراد به القاعدة النحوية الأقوى، والأولى أيضا()، قال سيبويه: "وسألت الخليل عن

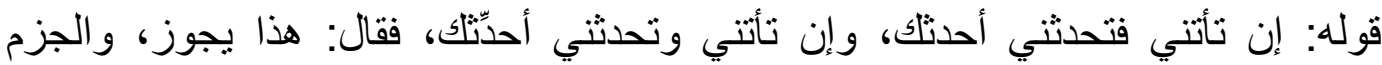

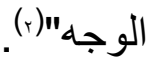

كذلك قول المبرد: "فإن قلت: من يأتتي آته فأكرمه كان الجزم الوجه، والرفع جائز على

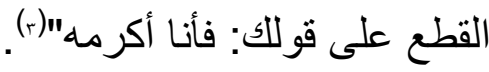

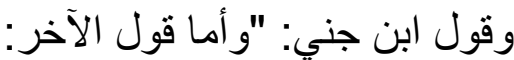

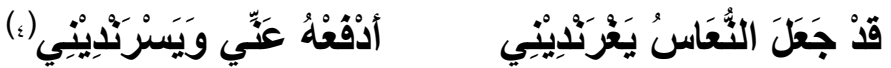

فللك فيه وجهان: إن شئت جعلت رويه النون، وهو الوجه. وإن شئت الياء، وليس

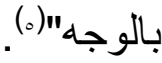

الثالث: يراد به القاعدة مطلقا، فمنه قول المبرد: "وكذلك إن بنيت واحدا من الواو على فلى

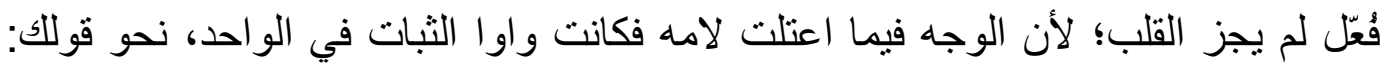

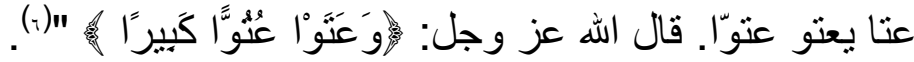

ومنه قول ابن فارس: "وفٌْ - جواب لمنوقَع، وهي نقيضُ (ما)التي للنفي، وليس من الوجه

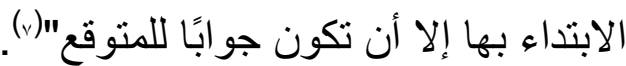

الرابع: يراد به كما في المعنى اللغوي القصد في الكلام، أو المذهب الذي يُّهب إليه

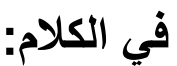
فمن ذلك قول ابن السر اج:" واعلم: أن رُبَّ تستعملُ على ثلاثة وجوه:

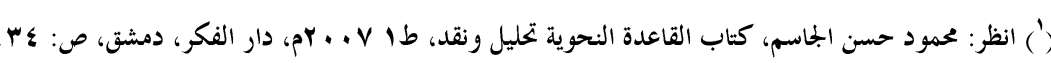

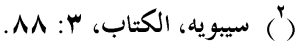

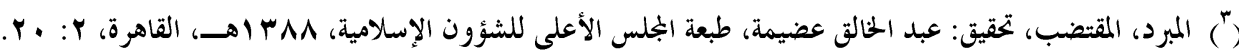

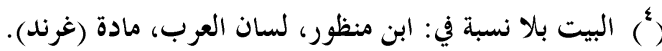

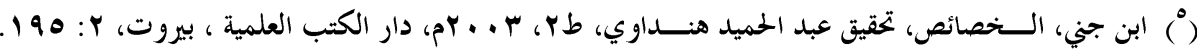

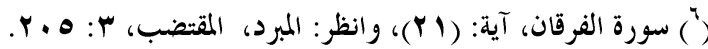

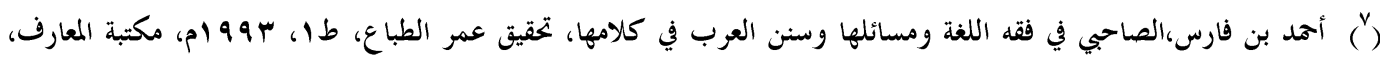


الوجه الأول: هو الذي قد ذكرت من دخولها على الاسم الظاهر النكرة وعمها فيه وفي صفته الجر. الوجه الثاني: دخلوها على المضمر على شريطة التفسير. الوجه الثالث: أن تصلها فتستأنف ما بعدها وتكفها عن العمل"(.).

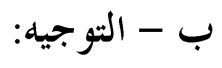

اتضح لنا من الحديث السابق أنّ الوجه النحوي يشمل الأحكام النحوية، والصرفية

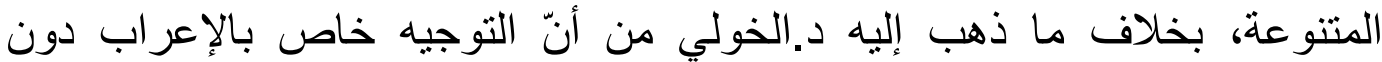

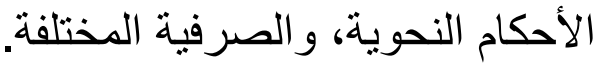

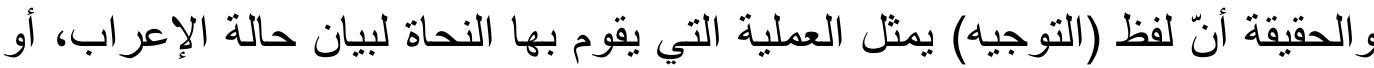
الحكم النحوي، أو الحكم الصرفي كما بيّنا.

على أنّ ما يحتاج إلى مناقتته هو حدود هذه العملية النحوية، إذ يرى بعض الباحثين

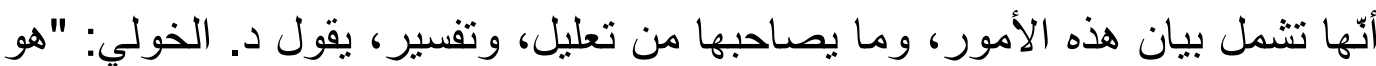

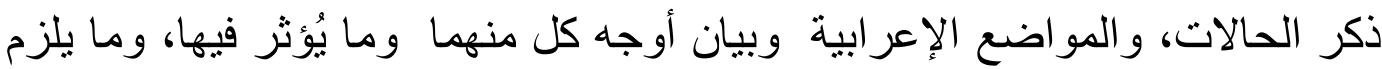

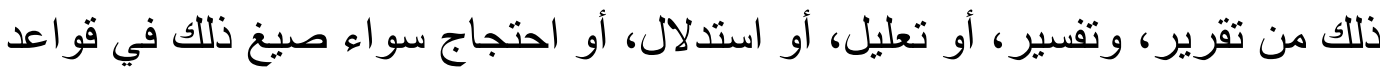
تضبطه، وتنظر له أم لم يُصنغ "(r).

ونرى أنّ مفهوم التوجيه النحوي بهذا المعنى صار مر ادقًا لمفهوم الاجتهاد النحوي. وليس ثمة دليل من نصّ منقول عن النحاة، أو حجة معقولة من الفهم تساعدنا على

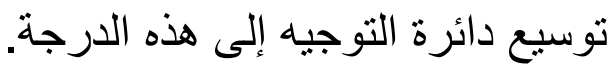

كذلك نرى بناء على ذلك أنّ الأولى بنا هو الاقتصار على ما يؤيد اللفظ معجميَّا،

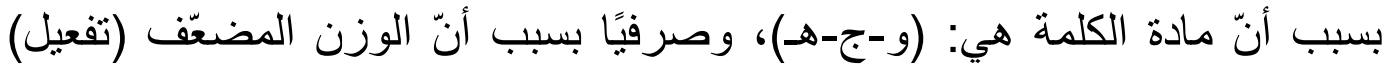
وهو ما يمثل في نظر البحث في كونه مجرّد النسبة إلى الوجاه، أو اعتقاد الوجاه،

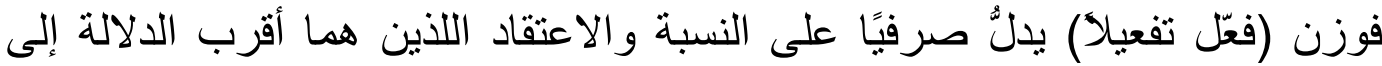

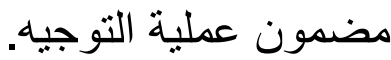

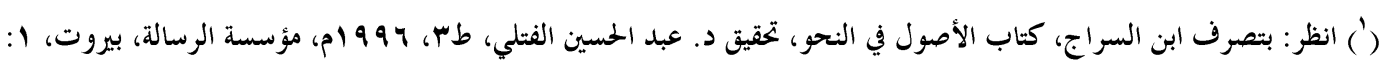


أما ما يذكر مع التوجيه من تفسير، وتعليل، فإنهم لا ينصون على كونه نصسًا في

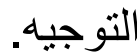

على كل حال فإنّ ذكر هذه الحالات الإعرابية()، أو الأحكام النحوية، والصرفية

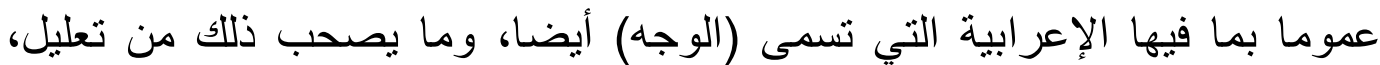

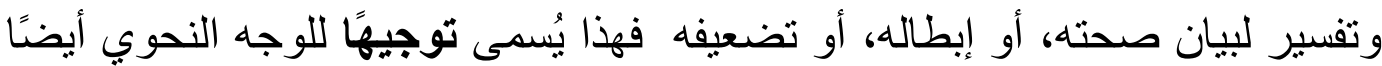
مع ما بصاحبها.

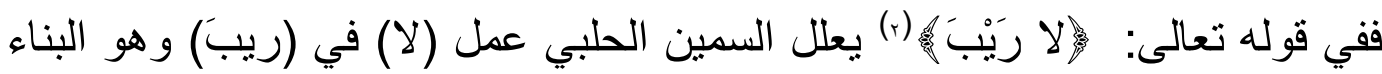

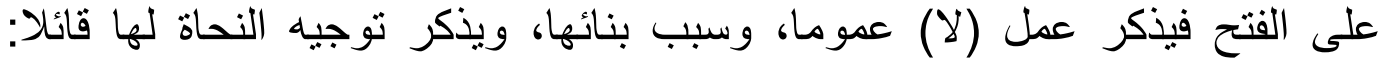

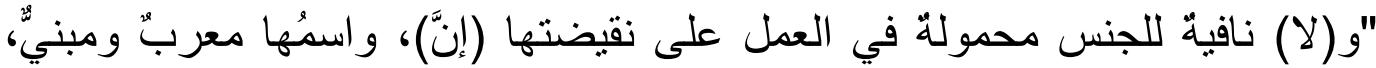

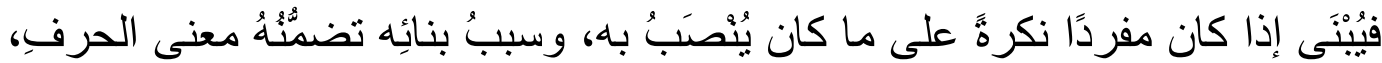

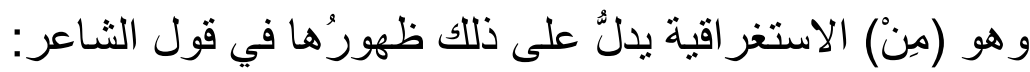

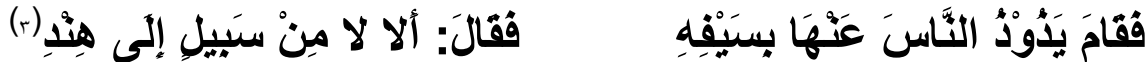

وقيل: بُني لتركَبه معها تركيبَ خمسة عشرَ وهو فاسدُ، وبيائه في غير هذا الكتاب. وزعم الزجاج أنَّ حركة (لا رجل) ونحوه حركة إعراب، و وإنما حُذِف التنوين تخفيقًا،

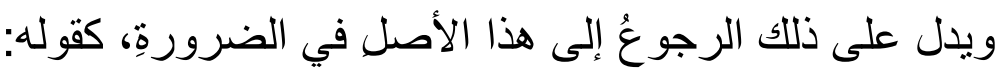

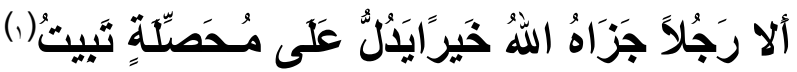

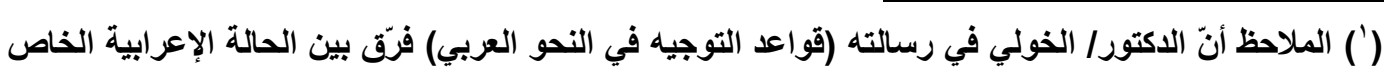

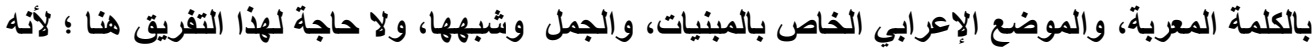
صرّح بأن النحاة القدماء لم يفرقوا بين الموضع الإعرابي، والحالة الإعرابية . هذا من ناحية، ومن ناحية أخرى فالمصطلحان وإن كان هناك فرق بينهما إلا أنهما متفقان على أمر مهم، ألا و هو الوجه الإعرابي لما أريد إعرابه، سواء أكان الوجه خاص لكلمة معربة، أو مبنية، أو جملة، أو شبهها. فالذي يهمنا الوجه الإعرابي، وتوجيه هذا الوجه، سواء أكان الوجه الإعرابي خاص بالمحل، أو بالموضع.

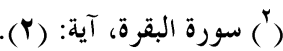

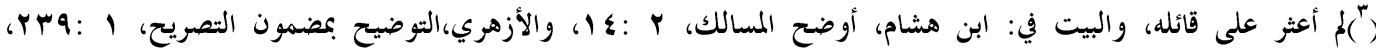

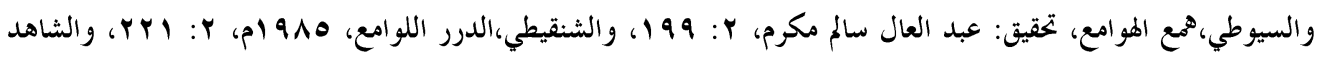
فيه قوله (ألا لا من سبيل) حيث ظهرت (من) مع الاسم الو اقع بعد (لا) فدل ذلك على تضمن الاسم معناها إذا لم تذكر معه. 


$$
\text { ولا دليلَ له ؛ لأن التقديرَ: ألا ثَرَوْنني رجلا؟ }
$$

فإن لم يكن مفردًا -و أعنى به المضاف و الثبيهَ بِهِ أعرب نصبًا نحو: لا خيرًا من زيد. وولا عملَ لها في المعرفةِ البتة، و أمَّا نحوُ:

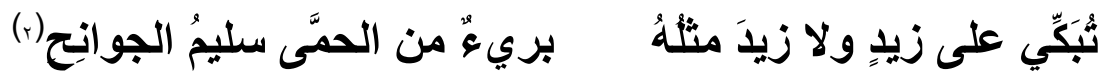

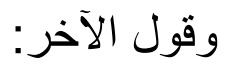

تَكِدْنَ ولا أمَيَّة فِي البِلادِ(r) أرَى الحَاجَاتِ عِنَا أبِي خُبَيْبِ

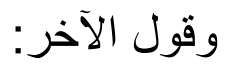

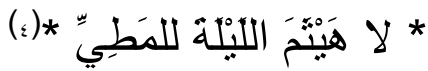

وقولِهِ عليه السلام: "لا قريشَ بعد اليوم، إذا هَلَّكَ كسرى فلا كسرى بعدَه" فمؤولٌ.

$$
\text { و "ريبََ- اسمُها..."(م). فالملاحظ هنا عدة أمور: }
$$

الأول: كون (ريبَ) اسم لا النافية للجنس.

الثاني: تعليل عمل (لا) النافية للجنس النصب، وهو حمل على نقيضنها (إنّ)، و هذا قياس. الثالث: كون اسم (لا) النافية للجنس مبنيا، أو منصوبا.

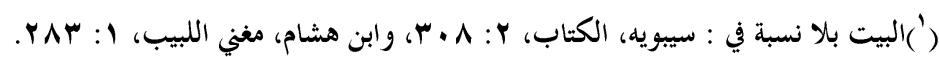

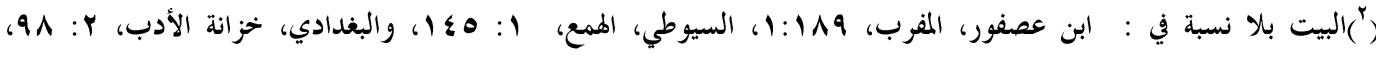

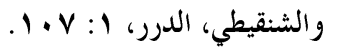

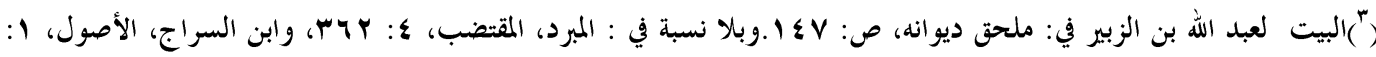


الر ابع: تعليل بناء اسم (لا) النافية للجنس، وهو لتضمنها معنى الحرف (مِن). الخامس: استدلاله بالسماع على بناء اسم (لا) لتضمنه معنى الحرف. السادس: فسَّد رأي من ذهب إلى أنّ التركيب هو سبب بناء اسم لا، ولم يعلل. السابع: ردّ على من زعم- وهو الزجاج- أنّ حركة اسم (لا) المفرد النكرة

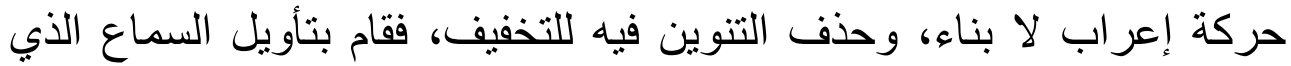
ذكره الزجاج للاستدلال على رأيه.

هذا ما يهمنا في هذا النص، فنلاحظ أنّ السمين الحلبي لم يكتف بذكر الوجه

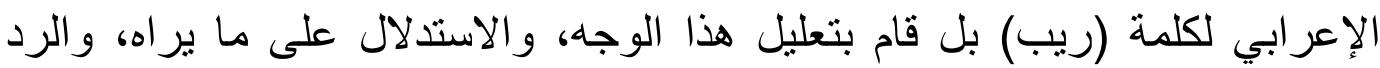

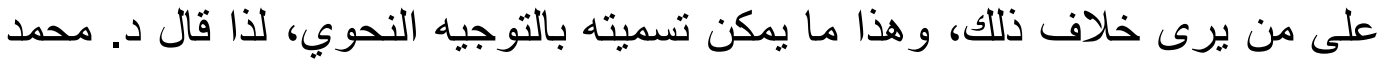

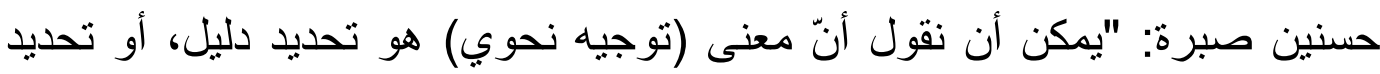

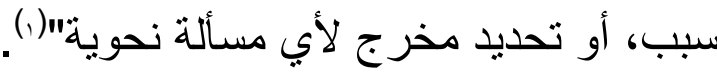

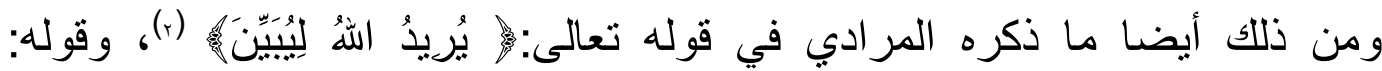

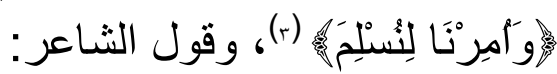

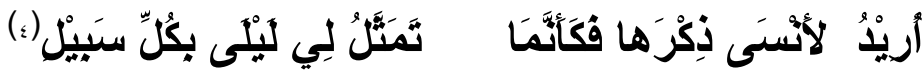

وذللك أنّ من النحاة من ذهب إلى أنّ اللام في (ليبين- لنسلم- لأنسى) لام كي، فقال:

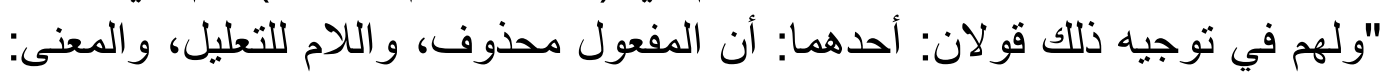

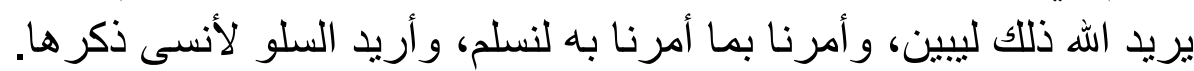
و الثاني: ما حكي عن سيبويه وأصحابه، أن الفعل مقدر بالمصدر، أي: إرادة الله

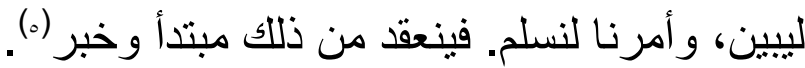

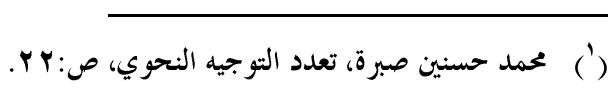

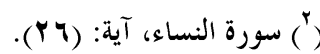

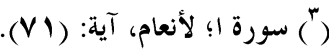

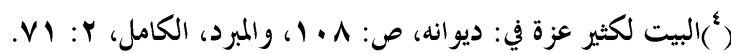

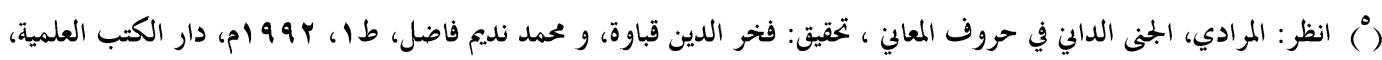


فنلاحظ أنهم ذهبوا إلى حكم إعرابي وهو أن اللام لام كي، ثم قامو ا بتفسير هذا الحكم

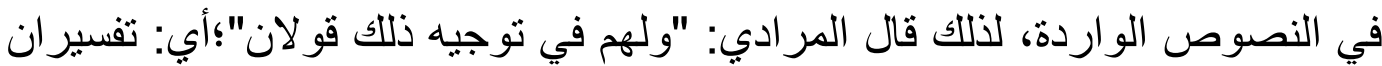

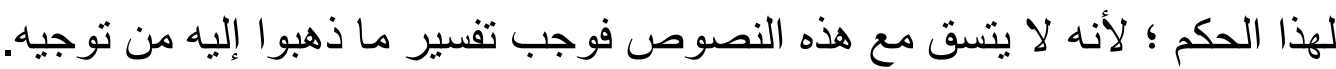
وتعريف الدكتور/الخولي السابق يقتصر فقط على الإعراب كما في تعريفه للوجها،

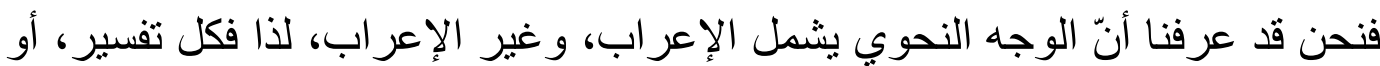

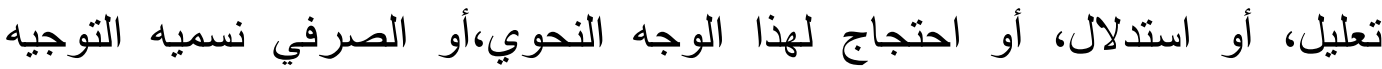

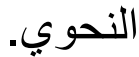

وقد قدّم الأستاذ الدكتور/تمام حسّان تعريقًا للتوجيه أدق من تعريف الدكتور/عبداله

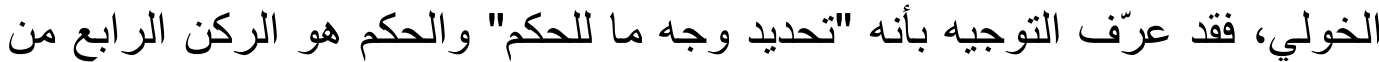
أركان القياس "فهو بذللك لا يختص بالإعراب فقط، بل يشمل الحكم، الذي بدوره يكون الركن الرابع في القياس النحوي، فيشمل بذللك الإعراب وغير الإنير الإعراب، وقد

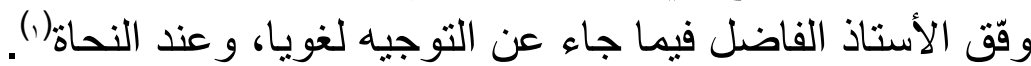

ففي المثال الذي أوردناه عن السمين الحلبي ترى أنه علَّ أولا نصب (ريب) على أنه

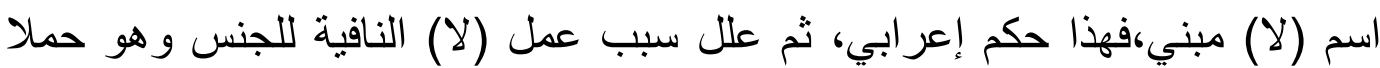

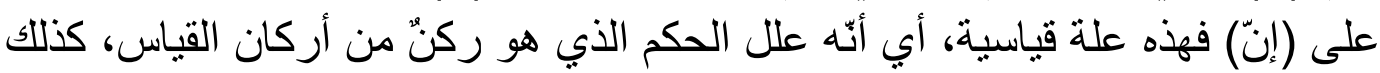

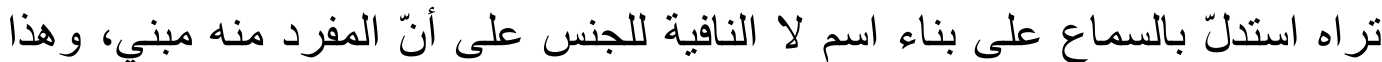
استدلال للحكم، واعترض أيضا على السماع الذي استدل به الزجاء لإن لإلثبات حكم

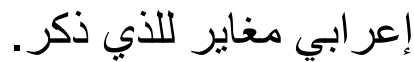

فالتوجيه النحوي بذلك هو: ذكر الحكم النحوي - سواء أكان الركن الرابع من أركان

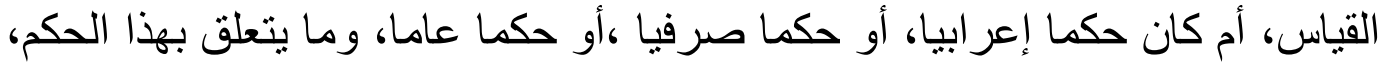

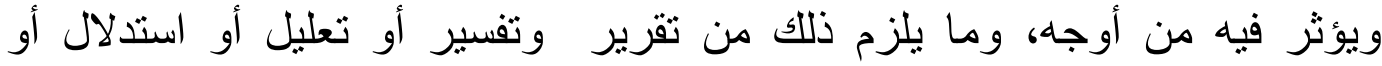

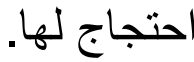


وقد قسَّم الأستاذ الدكتور/تمام حسّان التوجيه إلى توجيهين بحسب دوره، توجيه استدلالي، وتوجيه تأويلي (1)

و التوجيه الاستدلالي يكون إما على مسموع، أو على قياس، فمن المسموع قولهم في

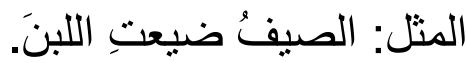

فلا تغيير في كسر تاء (ضيعت) و إن كان المخاطب مذكر ا؛ وذلك ؛ لأن الأمثال لا

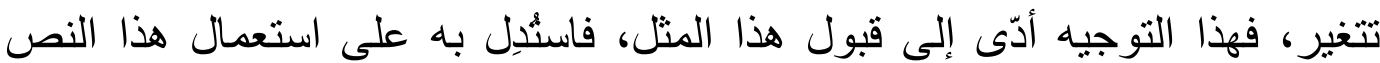
المسموع كما هو دون تغيير.

و التوجيه الاستدلالي في القياس نحو كأن يوجّه إعراب الفعل المضارع حملا على نه

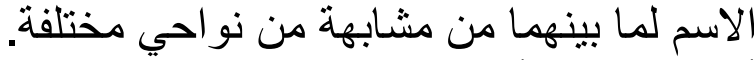

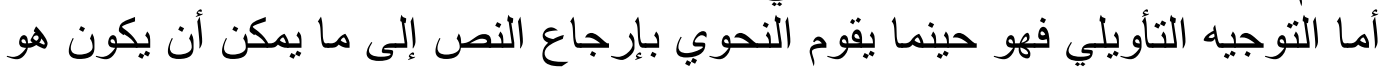

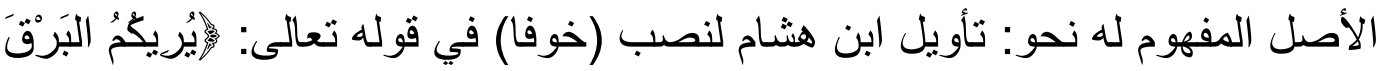

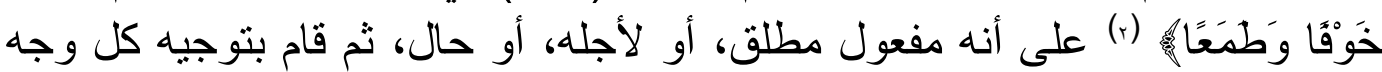

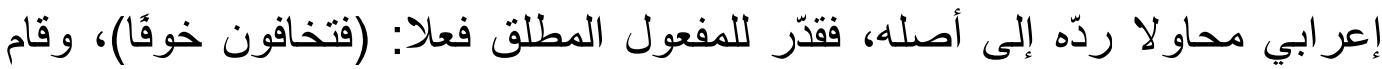

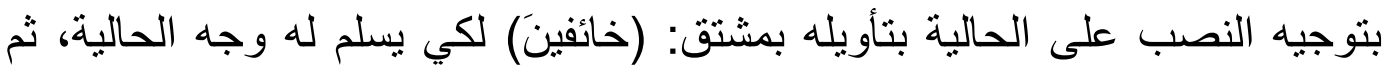

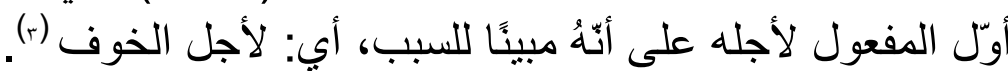

أما حينما يبدو النص غير مقبول للوجه المختار، فإنّ النحوي يقوم بتوجيهه بالتأويل

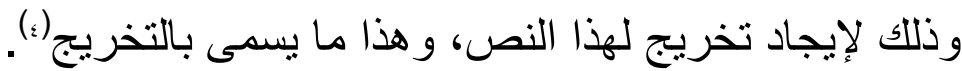
فمن ذللك قولهم في قول الثناعر:

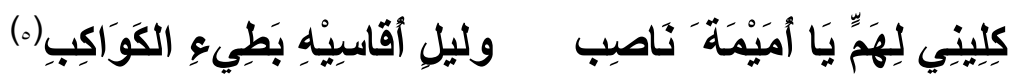

(') انظر : تمام حسان،كتاب الأصول دراسة إبستيمولوجية للفكر اللغوي عند العرب، طا، ... .بrم، الهيئة العامة للكتاب، ص: $r \cdot Y-r \cdot r$

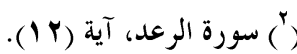

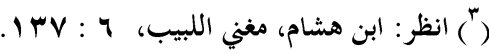

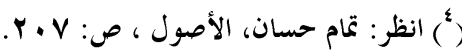

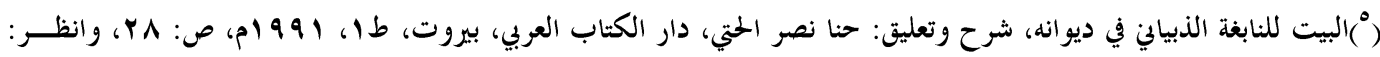


حينما نُصبت (أميمة) وحقها البناء على الضم ؛ لأنها مفردٌ علمّ قام النحاة بتخريج

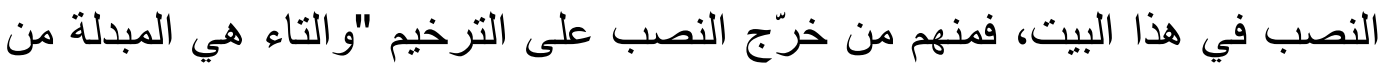

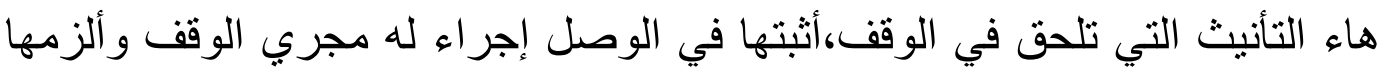

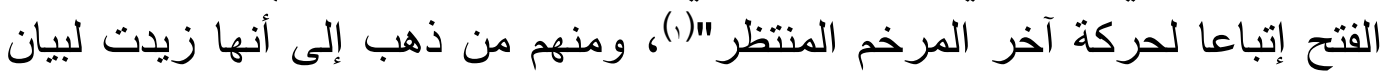

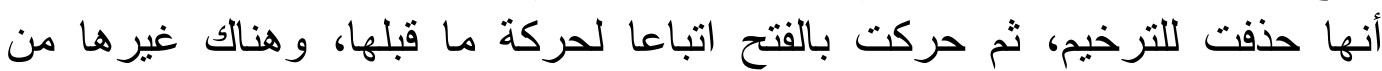

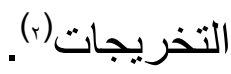

وكل هذه التخريجات المختلفة من أجل ردّ النص إلى حيّز القبول لا الرد، ولولاها

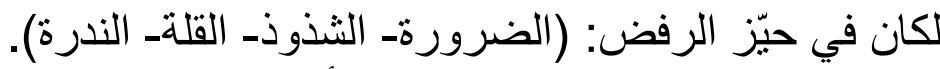

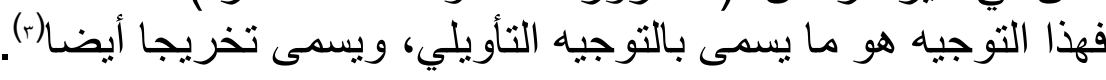
ولا يخفى بذلك أنّ الأستاذ الفاضل قد جعل الاستدلال، و التأويل كليهما من التوجيه،

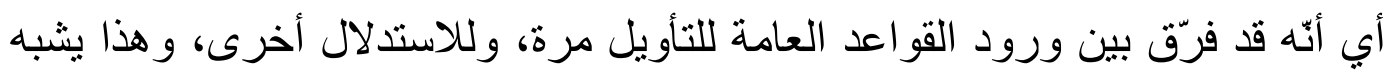

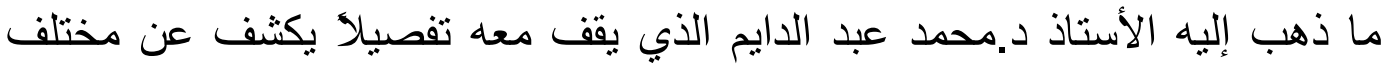

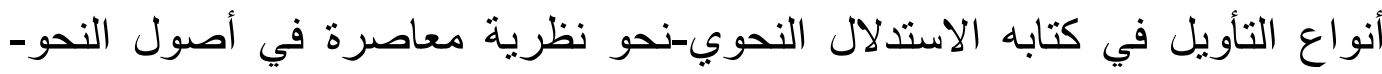

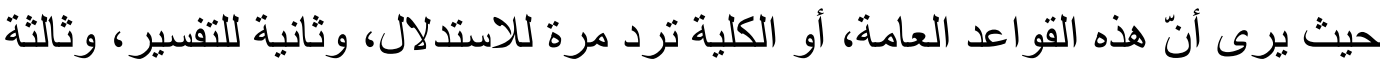

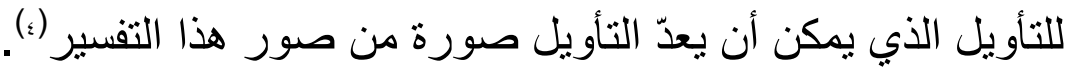

ذكر الأنباري هذا البيت ونسبه للنابغة من إنشاد أبي العباس ثعلب، وذكر أنَّ أبا العباس أجاز في فتح أُمَيْمَة ما أجازه الفــراء في فـــح

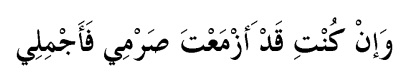

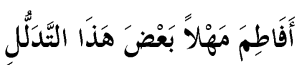

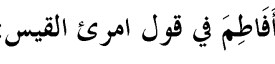

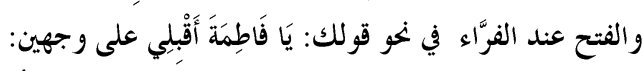

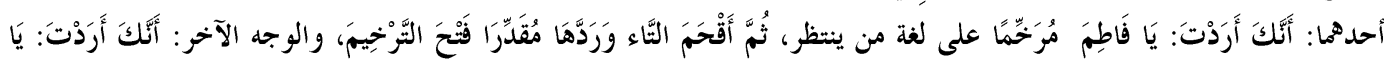

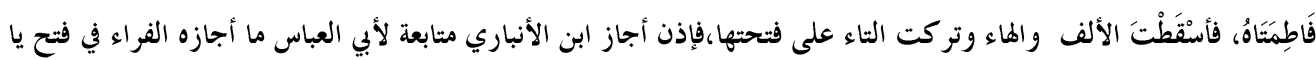

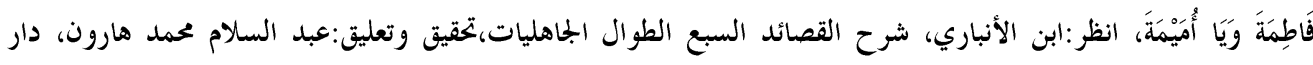

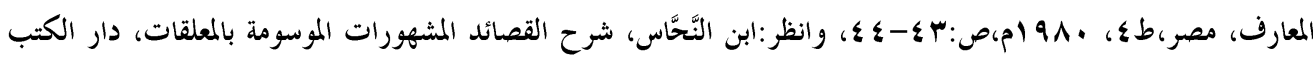

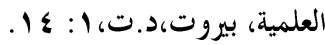

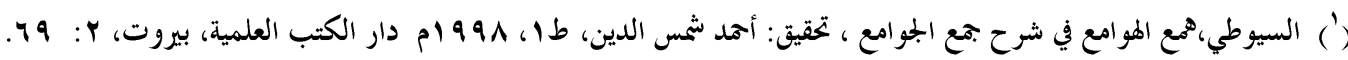

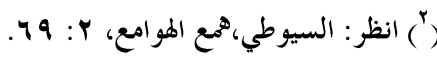

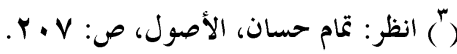

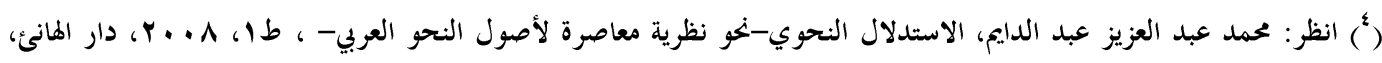

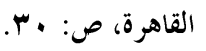


كما لا يخفى أنّه قد جعل التأويل، والاستدلال كليهما من باب التوجيه، وهذا ما لم

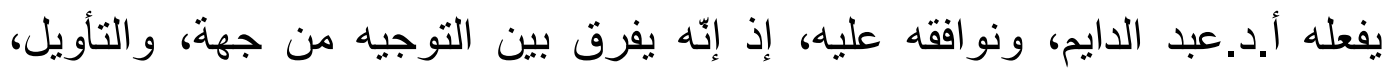
والاستدلال من جهة أخرى منلما يفرق بين التأويل من جهة، والاستدلال من التهن جهة

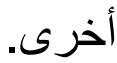

على أنّ هناك سؤالا هو: هل يقوم النحاة بالتوجيه بأنو اعه المختلفة بطريقة عشو ائية،

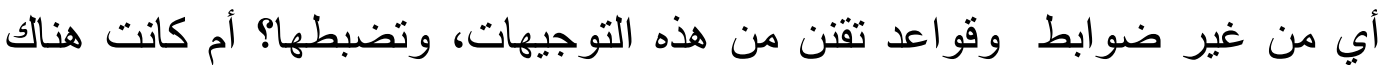

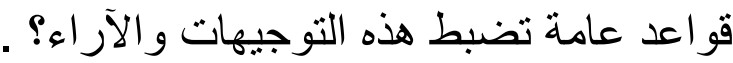

الواقع أنّ النحاة حينما يقومون بالتوجيه "ويبدون آراءهم في المسائل لم يكونوا

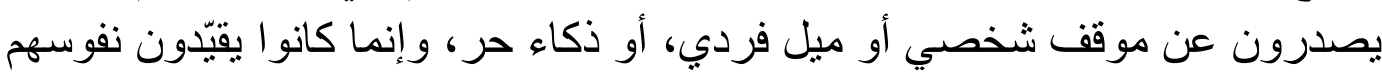

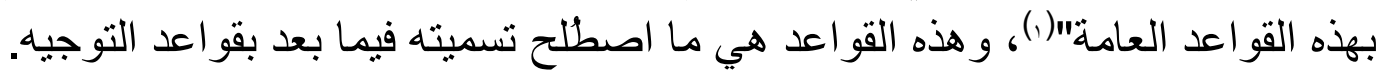

فقواعد التوجيه هي: قو انين تضبط ما ذكره النحاة من توجيه، وتنظر له، وقد صيغت

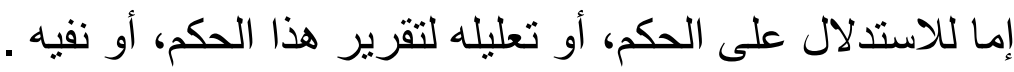

وهي في الحقيقة القواعد الضابطة لهذه الأوجه، و المؤثرة في الاختيار، وتفضيل أحدها على الآخر.

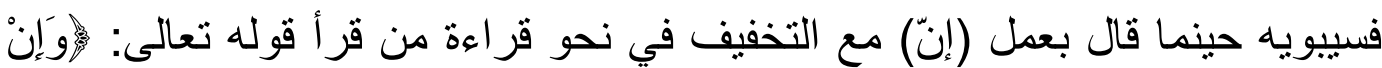

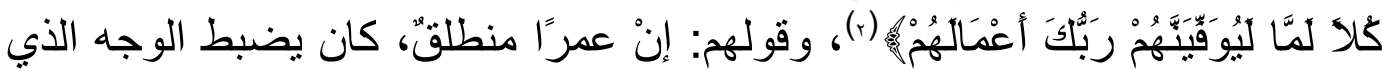

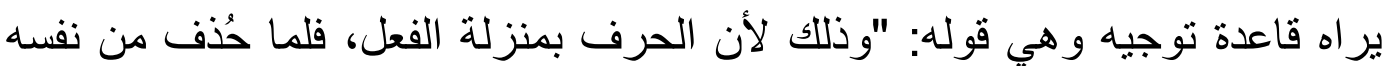

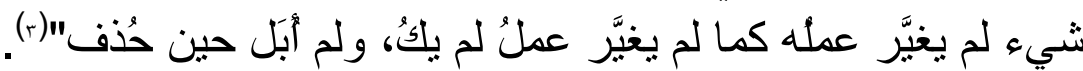

فسييويه إذن حمل أو لا عمل (إنّ) على الفعل، ثم قام بالاستدلال على توجيه عملها مع

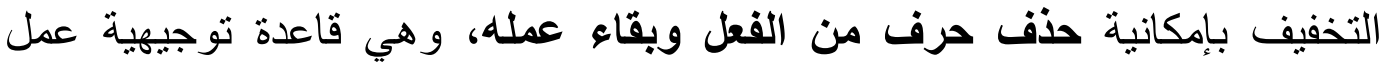
بمقتضاها (حذف حرف من الفعل لا يغير عمله).

$$
\begin{aligned}
& \text { (') انظر : تمام حسان، الأصول ، ص: .919. } \\
& \text { (') سورة هود، آية: (11) (11). }
\end{aligned}
$$

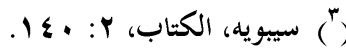


وحينما نفى بعض النحاة كالخليل وسييويه و ابن جني القول بأن الواوات ما بعد الو او

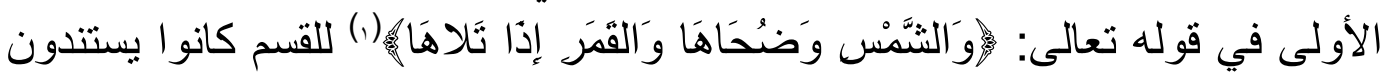
إلى ذلك بقاعدة توجيهية هي لا ياخل قسم على على قسم(r)، فقد حكمت تقرير نفي كون

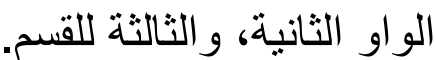

و عندما ذكر المبرد نفي عمل (إذن) إذا وقعت في وسط الكلام اعتمد على قاعدة

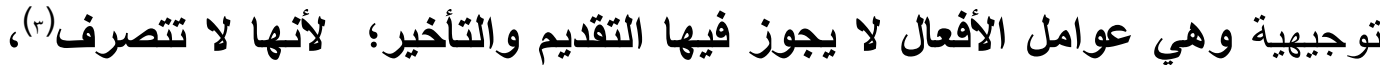
فقام بتعليل هذا الوجه بقاعدة نوجيه. وقد ذهب أيضا إلى إنكار إضمار الجازم في قول الثاعر:

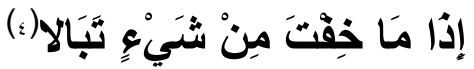

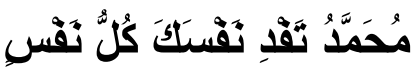

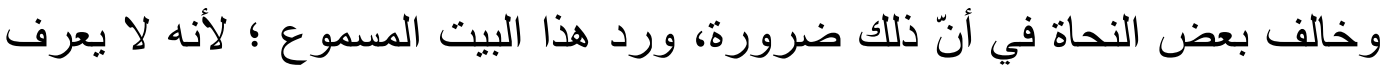

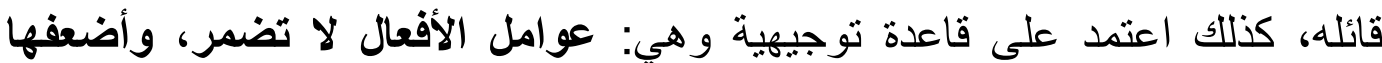

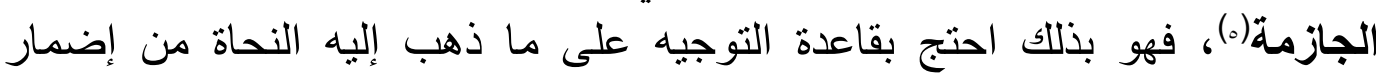
الجازم في (تفرِ).

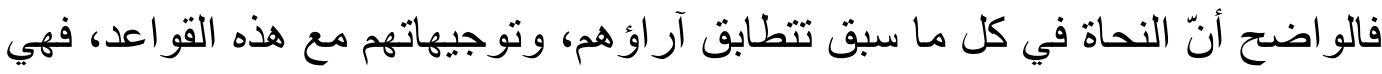

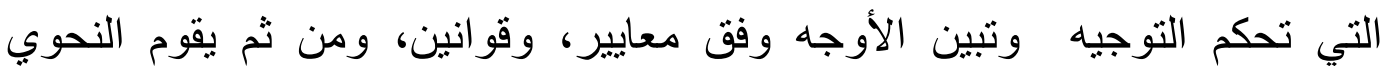
بالاحتجاج لهذا التوجيه، أو تفسيره، أو تعليله، أو الاستدلال وقليه عليه.

و هذا التعريف شامل لكل أنواع قواعد التوجيه على اختلافها، إلا أننا سوف نفصل

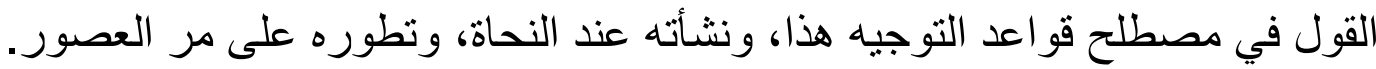
ثانيًا: مصطلح قواعد التوجيه بين القديم والحمديث:

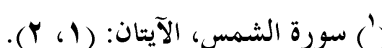

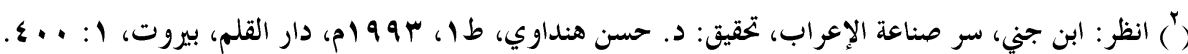

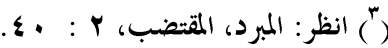

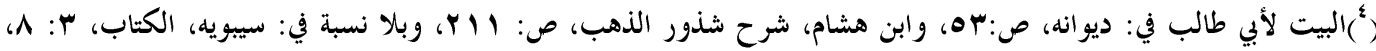

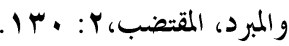

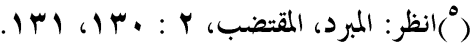




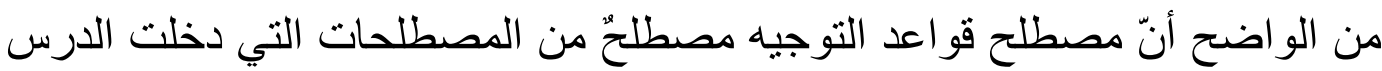

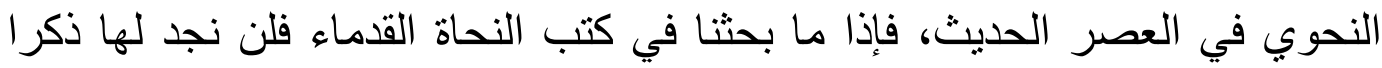

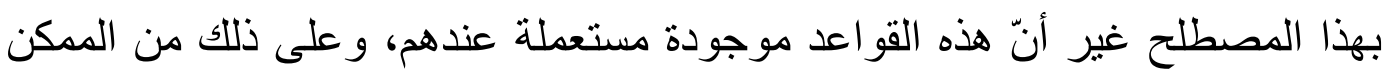
تقسيم مر احل نشأة هذا المصطلح إلى مرحلتين:

\section{المرحلة الأولى: في الدرس النحوي القديم:}

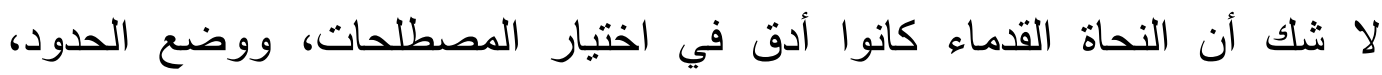

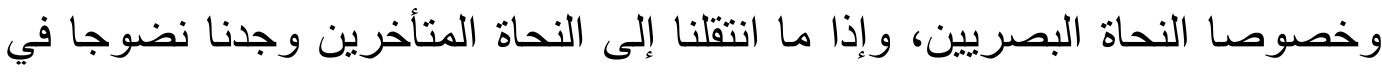

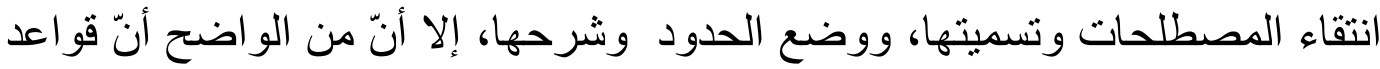

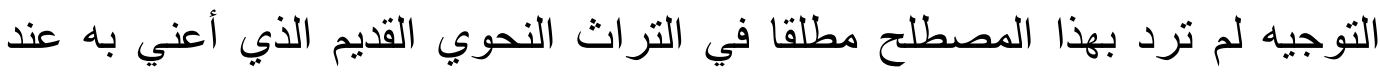

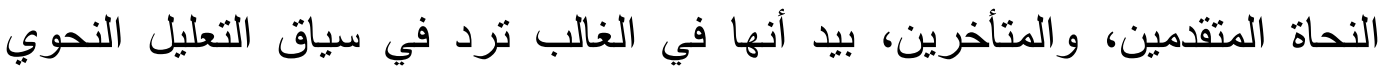

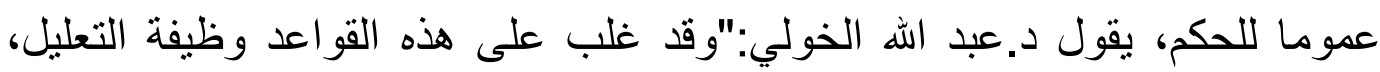

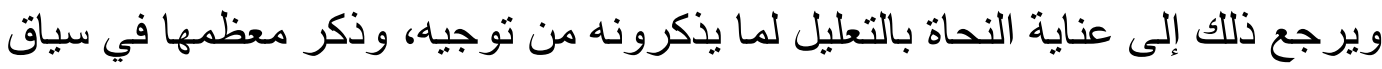
يفيد ذلك")(1)

فمثال ذلك قول سيبويه في باب: "ضربت وضربني زيد، وضربني وضربت زيدًا، تحمل الاسم على الفعل الذي يليه.

فالعامل في اللفظ أحد الفعلين، و أما في المعنى فقد يعلم أن الأول قد وقع إلا أنه لا يعمل في اسم واحد نصب ورفع" (r). فالملاحظ في هذا المثال أنّه عَّلَ قوله:" (العامل في اللفظ أحد الفعلين) بقاعدة

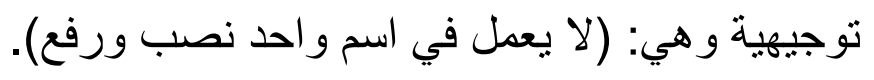

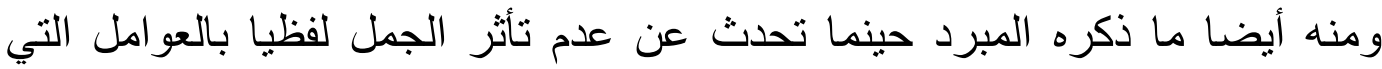

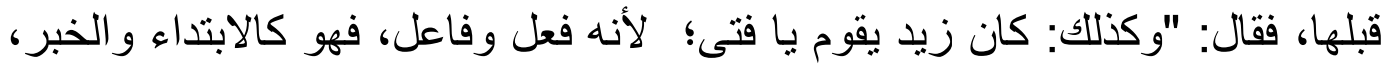

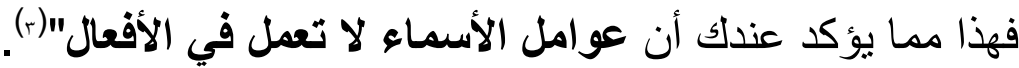

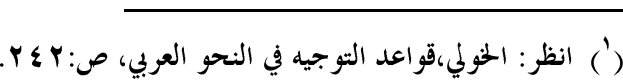

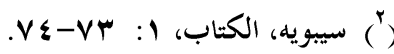

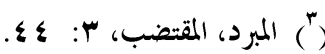


فحينما عَلَّ عدم تأثر جملة (يقوم) بالعامل (كان) ساق القاعدة التوجيهية للتأكيد: (عو امل الأسماء لا تعمل في الأفعال).

فهذه القواعد ترد عند النحاة في سياق التعليل النحوي، إلا أنّ لها وظيفتين عند النحاة لَّاة

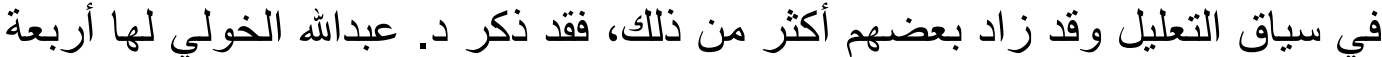

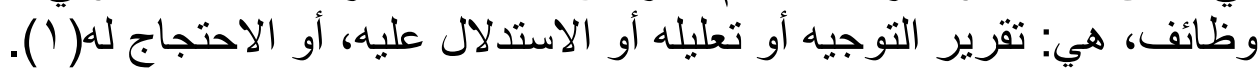

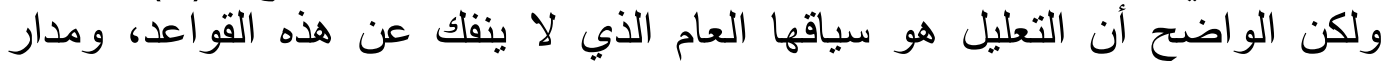

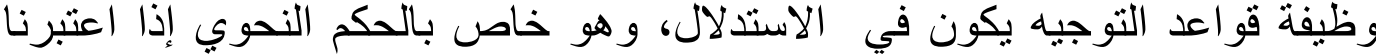
تعريف التوجيه، و الوجه على اعلى بيّناه. أما توظيف النحاة لها فمعلوم للقارئ أنّ السياق سياق تعليل لكن هذا السياق سيق

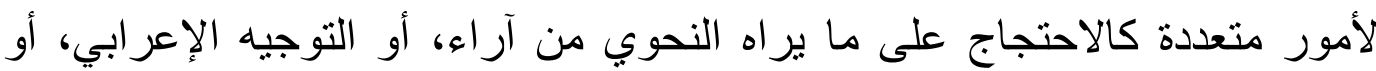

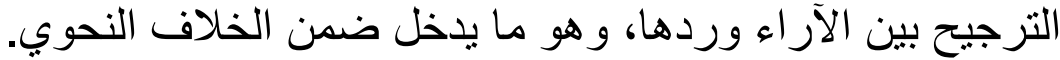

و هاتان الوظيفتان توضحان حقيقة قو اعد التوجيه عند النحاة القدماء، وبيانهما كما يلي:

$$
\text { ا - الاستدلال على إثبات أو تقرير الحكم: }
$$

تعد وظيفة الاستدلال على إثبات، وتقرير الحكم من أهم وظائف قو اعد التوجيه؛ لأنه

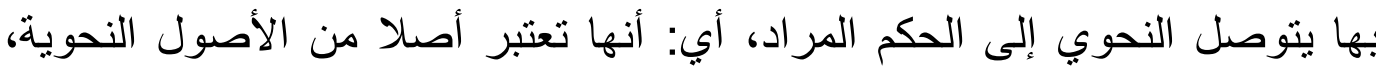
كالسماع، و القياس، والاستصحاب، و غير ها. فمن ذلك ما ذكره سييويه حينما استدل بقاعدة توجيهية في منع (أبيض، وأسود،

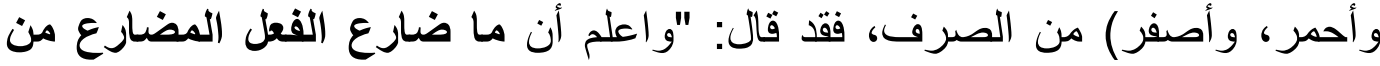
الأسماء في الكلام، ووافقه في البناء أجرى لفظه مجرى ما يستثقلتون، ومنعوه ما إنا

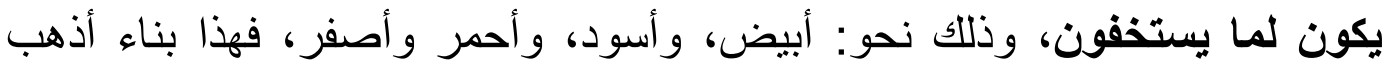

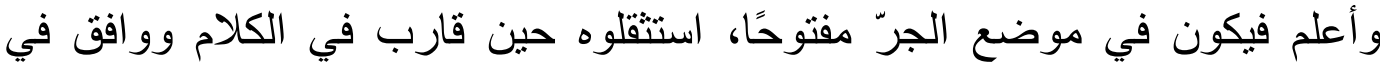

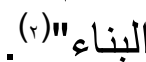

فقد استدل بقاعدة: (ما ضارع الفعل المضارع من الأسماء في الكلام، ووافقه في

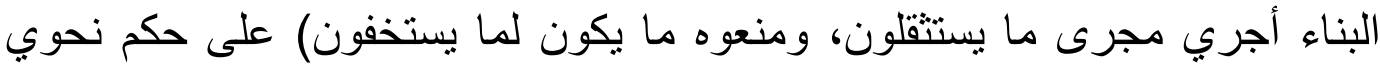

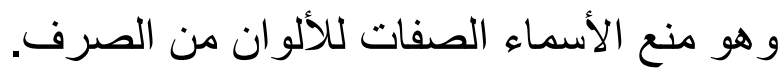

$$
\begin{aligned}
& \text { (') انظر : الحخولي، قواعد التوجيه، ص: إ؟Y. }
\end{aligned}
$$

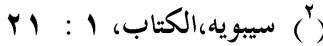




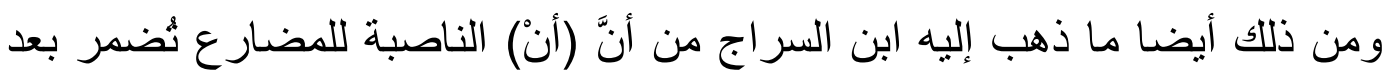

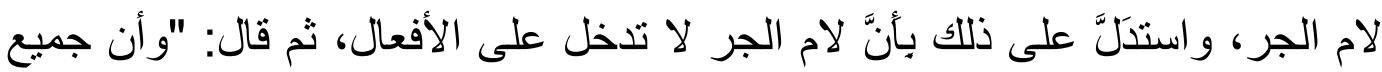

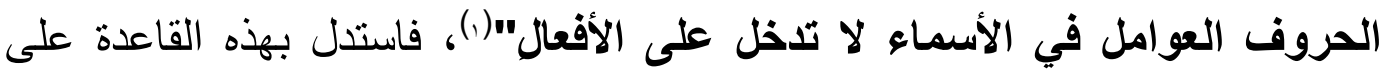

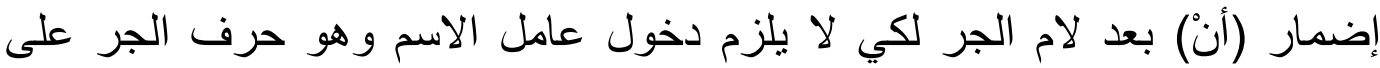
الفعل. - n

واستدل أيضا على إعراب الفحل المضار ع بقاعدة توجيهية وهي: (ما أنثبه الأسماء

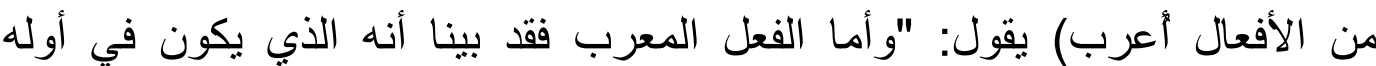

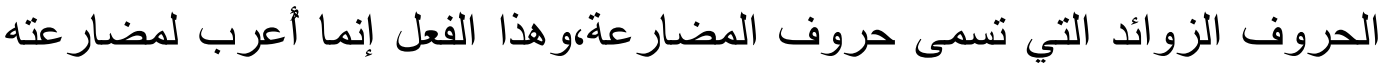

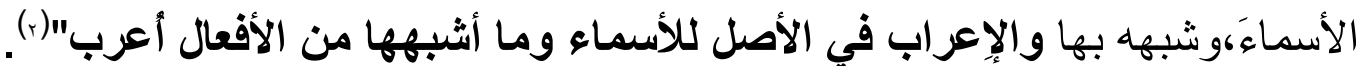
وابن عصفور تحدَّثَ عن اختلاف النحاة في (حبّدا)، فقد ذكر أنّ من يرى من النحاة

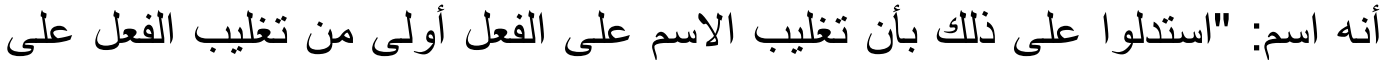

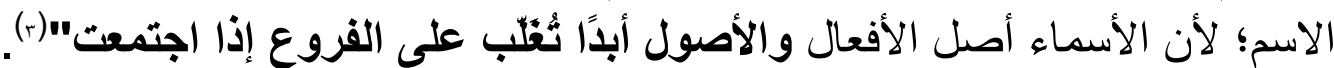
فقد استدلوا بالقاعدة التوجيهية: ( الأصول أبدا تغلب على الفروع) في الوصول إلى (إلى الحكم و هو اسمية (حَبَّنا).

وعلى ذلك تكون دليلا من أدلة النحو، وأصلا من الأصول النحوية، وقد ذكر

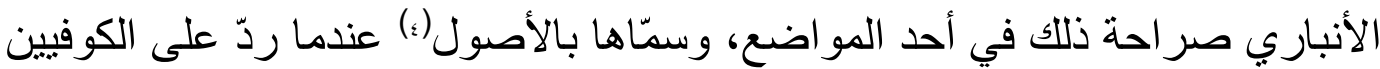

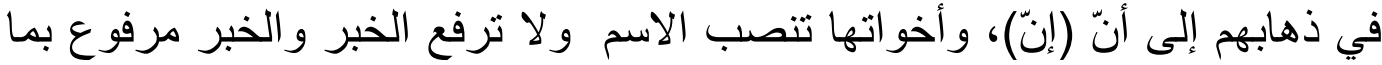

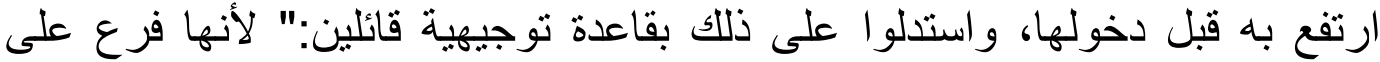

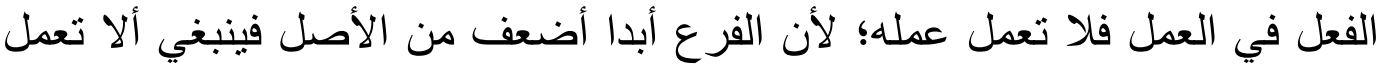

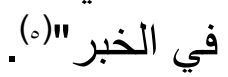

فقد رَذّ عليهم من عدة قو اعد عامة:

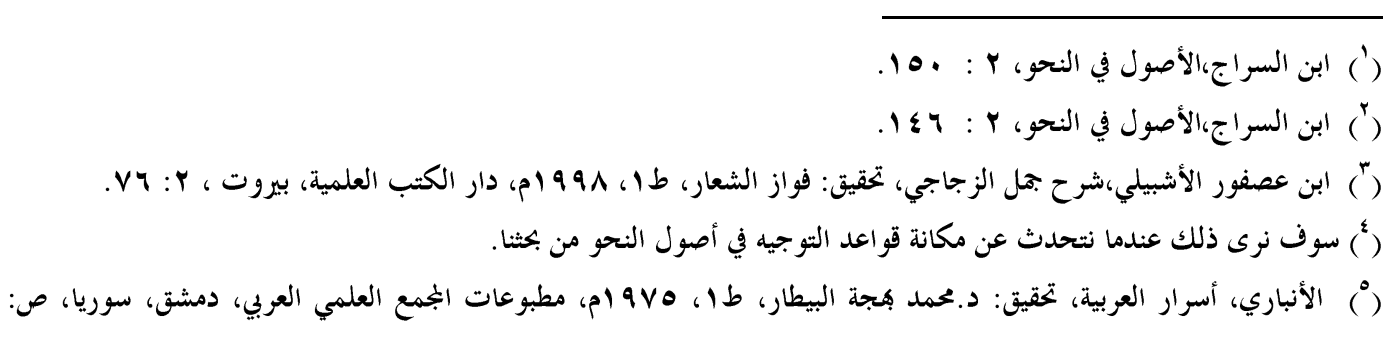


الأولى: ما استدلو ابه غير صحيح ؛ لأنه إذا نظرنا إلى أنّ ما حمل على الفعل فقد

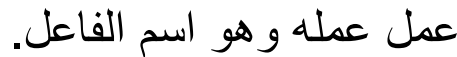

الثانية: أنه عمل بمقتضى ما ذكروه حينما أوجب تقديم المنصوب على المرفوع، ولم يجوّز الوجهين كما في الفعل الذي جاز تقديم المفعول به على الفاعل، وذلك عملا بأن النهان الفروع تنحط عن درجة الأصول.

الثالثة: أن الرفع للمبتدأ أولى من الخبر إذا سلّمنا برأيهم، فلما وجب نصب المبتدأ بـ(إنَّ)، وجب رفع الخبر بها أيضا.

ثم استدكَّ بقاعدة توجيهية لذلك قائلا:"ألنه ليس في كلام العرب عامل يعمل في الأسماء النصب إلا يعمل الرفع"'(1).

وختم ذلك بقوله: "فما ذهبوا إليه يؤدي إلى نرك القياس، ومخالفة الأصول لغير

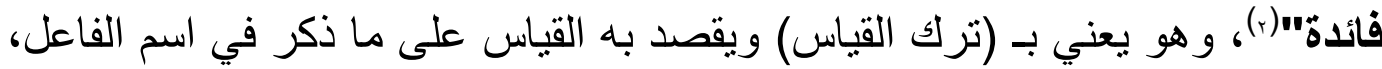

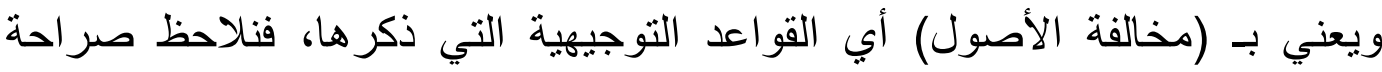

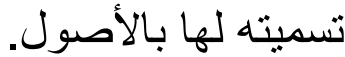

وقد صرّح بذلك أيضا مكي القيسي في كتابه: (مشكل إعراب القرآن)، فقد قال:

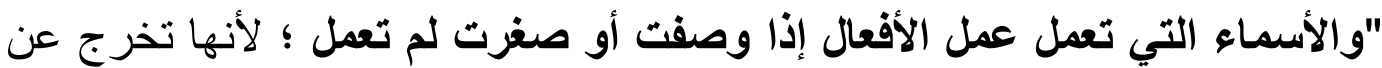

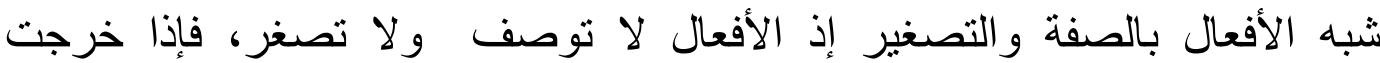

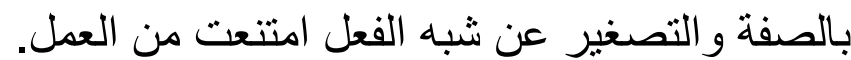

وهذا أصل لا يختلف فيه البصريون..."(.).

فقاعدة التوجيه هي: (الأسماء التي تعمل عمل الأفعال إذا وصفت، أو صغرت لم

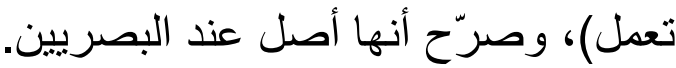

$$
\begin{aligned}
& \text { (') الأنباري، أسرار العربية، ص:101. }
\end{aligned}
$$

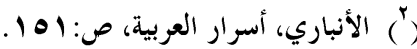

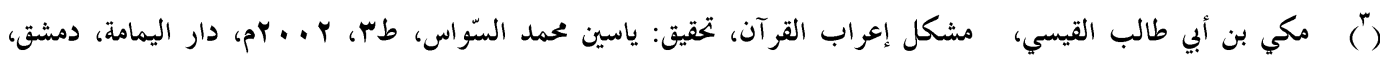

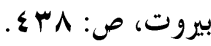


كذلك فعل الجرجاني حينما قال: "اعلم أنه يحتاج أولا في هذه المسألة إلى معرفة أصلين،

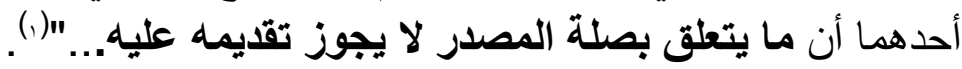
فكل ذلك دليل صريح على أنّ القدماء قد عرفوا أنها من الأصول، لكن الاصطلاح لم

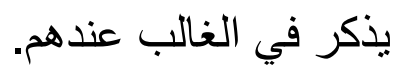

\section{r- الاستدلال على نفي الحكم، وردّه لتقرير غيره:}

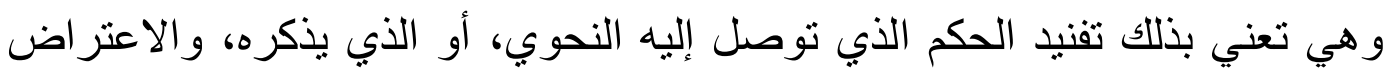
عليه لنفيه،وردّه و تقرير غيره بو اسطتها لنفي الحكم المخالف أو بغير ها.

فمن ذلك ما ذكره سيبويه حينما أراد تقرير عمل أحد الفعلين في الاسم المنصوب في

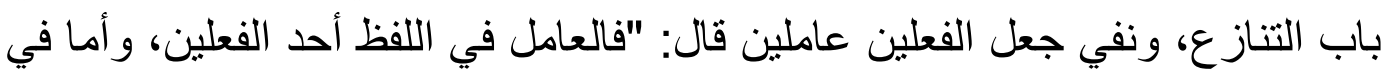
المعنى فقد يعلم أن الأول قد وقع إلا أنه لا يعمل في اسم واحد نصب في ورفع" (؟).

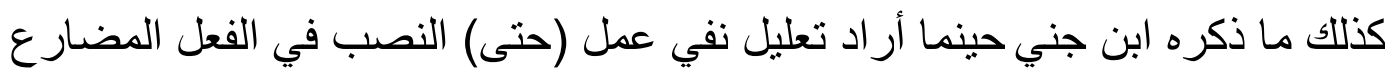

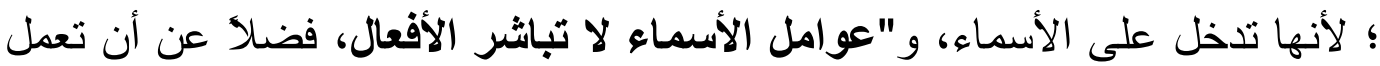

$$
\text { فيه")(r) }
$$

وحينما ذهب ابن هشام إلى القول بأن (أل) في العلم والاسم الموصول زائدة، وليست

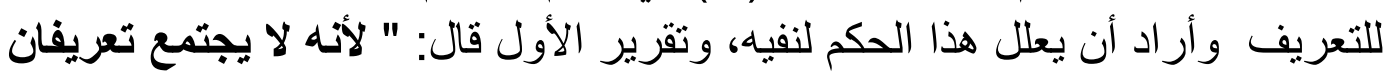

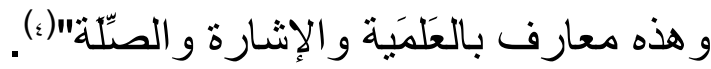

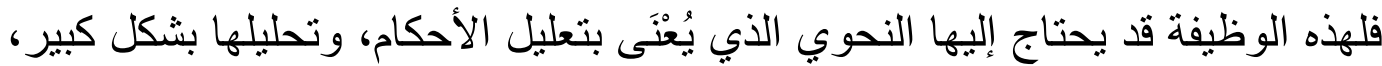

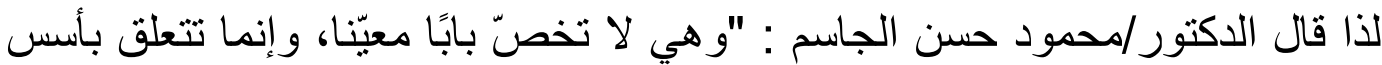

(') ،الجر جالني المقتصد في شرح الإيضاح، تحقيق: كاظم بحر المرجان، طا، بهو (ام، دار الرشيد، منشورات وزارة الثقافة، والإعلام،

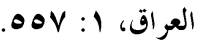

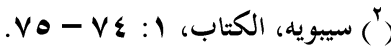

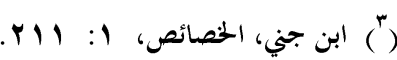

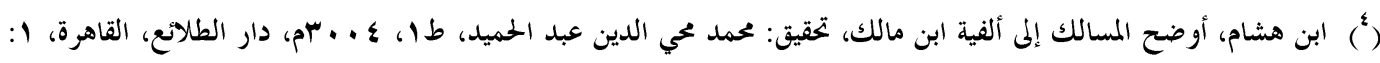


التحليل النحوي عامة، إذ قد يحتاج إليها النحوي في أبيّ باب ليتوصل بها إلى الحكم

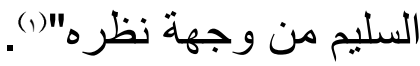

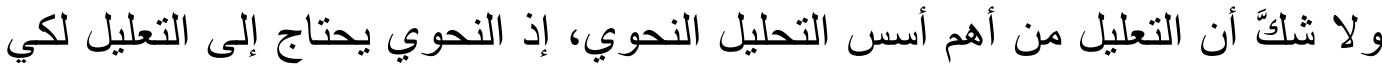

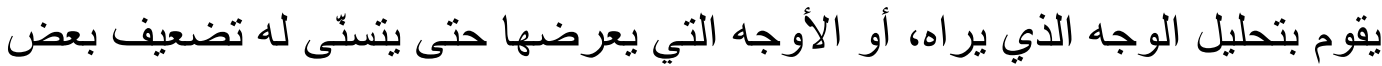

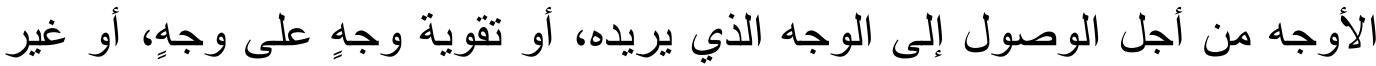

ذلك.

ولهاتين الوظيفتين يمكن القول بأنّ هذه القواعد تعتبر عند النحاة من الأصول النحوية

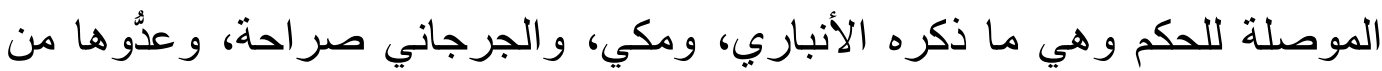

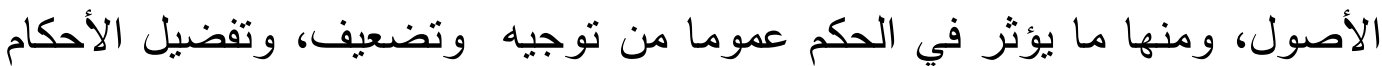
بعضها على بعض، وترجيح بؤر في فض الأحكام على بعض.

وقد عرض ابن هشام بعض هذه القواعد تحت عنوان: (أمور كلية) وذلك في كتابه

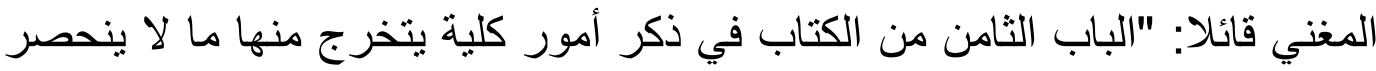

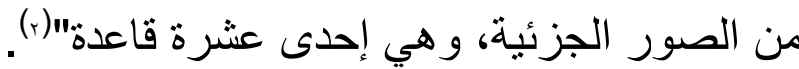

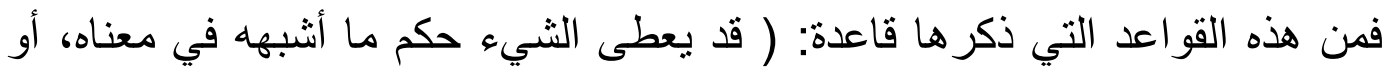

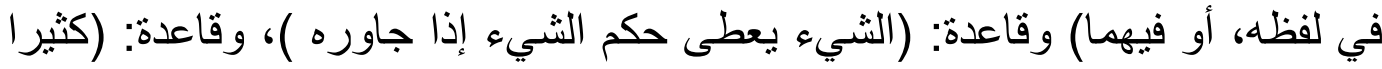

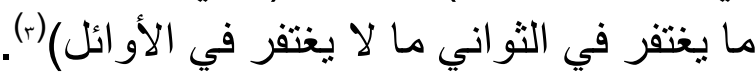

وقد ذكر السيوطي مجموعة من هذه القو اعد في كتابه (الأشباه والنظائر في النحو)

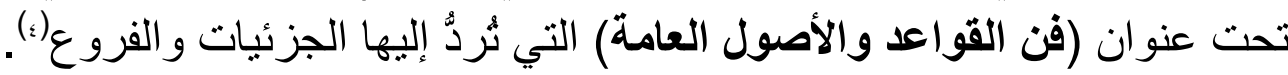

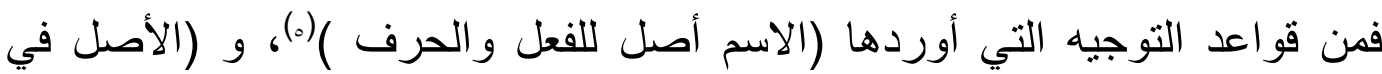

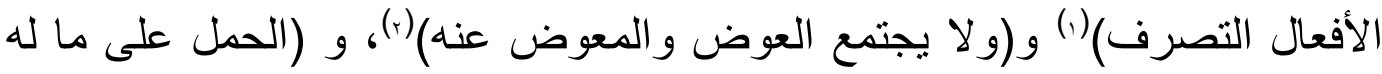

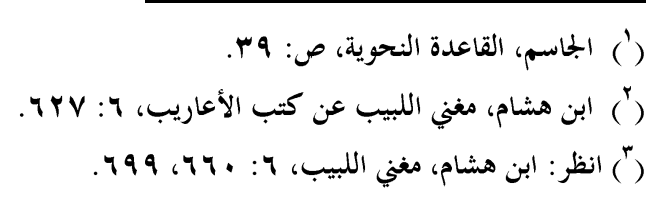

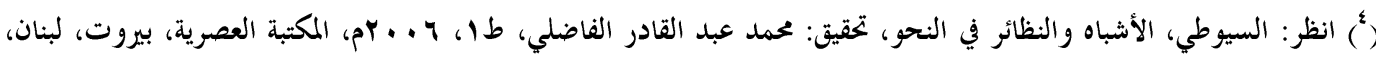

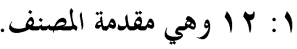

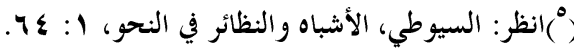




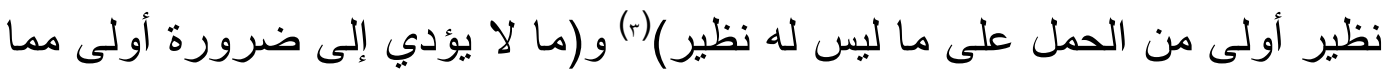

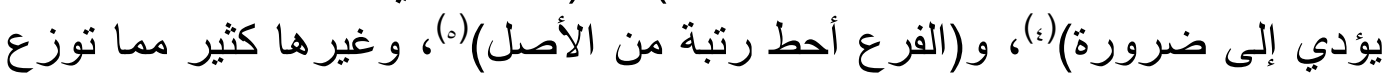

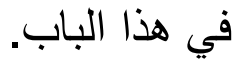

وخلاصة القول في ذلك: أن النحاة القدماء لم يصطلحوا على هذه القواعد اصطلاحا

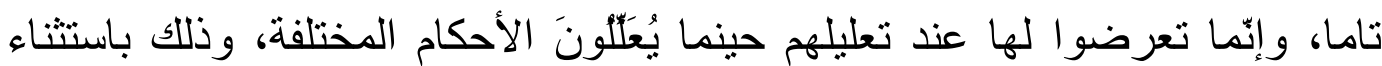

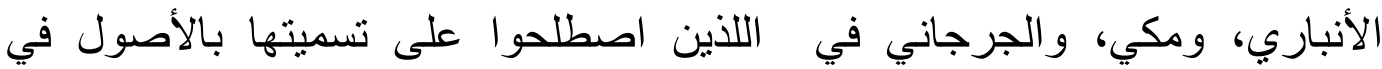

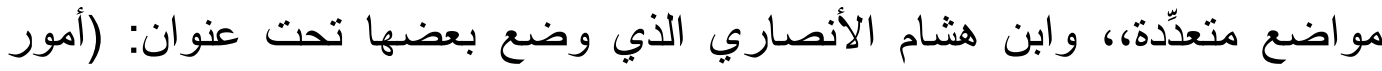

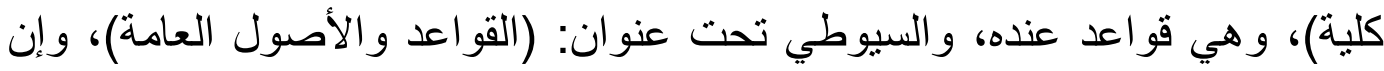
كان مدر اها على أنها من الأصول عندها والميول المرحلة الثانية: في الارس النحوي الحديث:

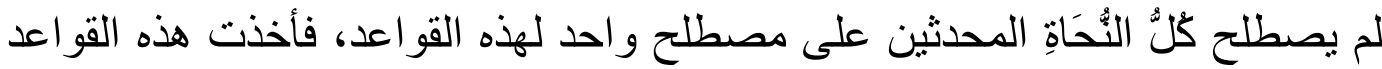
تتردد عندهم بين مصطلحين رئيسيين- و إن كانت عبار اتهم تحتمل اصطلاحات أست أكثر -

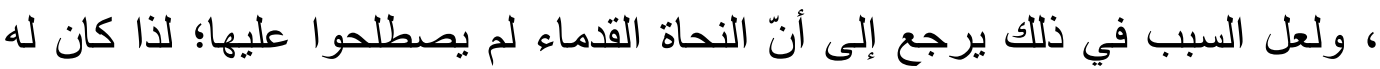

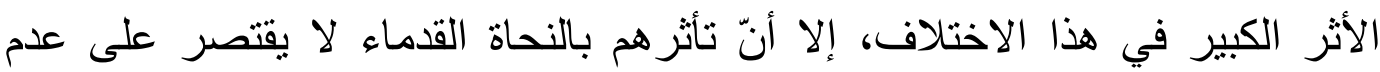

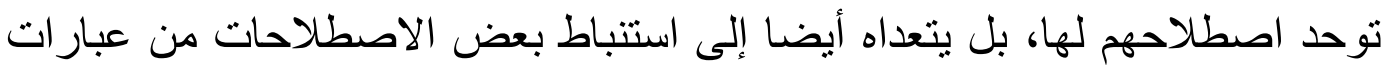

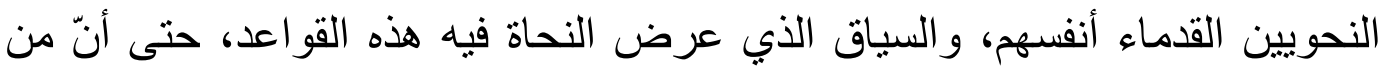

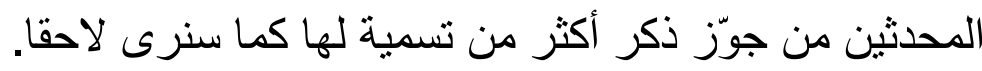

على العموم يمكن الوقوف على رأي الأساتذة، وعرض اصطلاحهم، وتعريفهم لها: ا ــ أد.عبد الرحمن السيّّ في كتابه (مدرسة البصرة) واصطلاحه لقواعد التوجيه (الأصول):

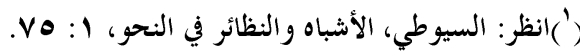

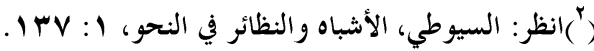

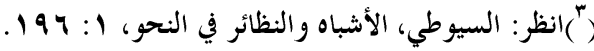

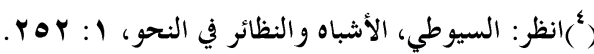

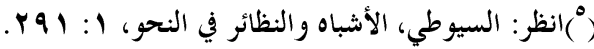


تناول الدكتور/عبد الرحمن السيّّ هذه القواعد في كتابه: ( مدرسة البصرة نشأتها

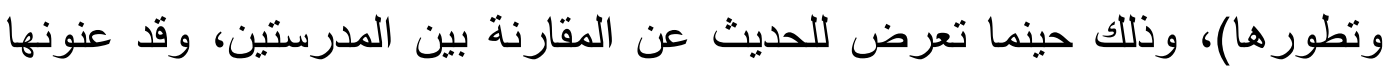

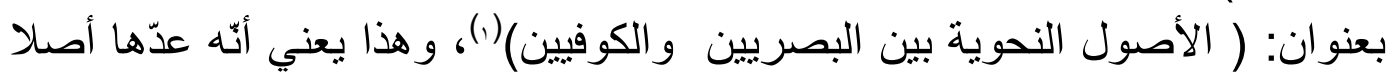

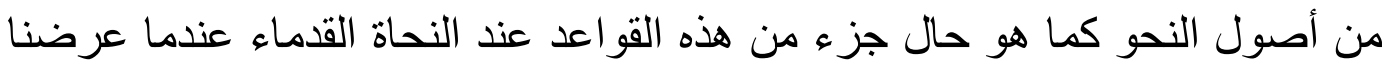

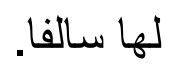

وقد ذكر الأصول المشتركة بين المدرسة البصرية، والمدرسة الكوفية، ثم الأصول

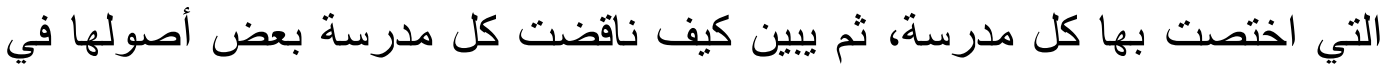
آرائها.

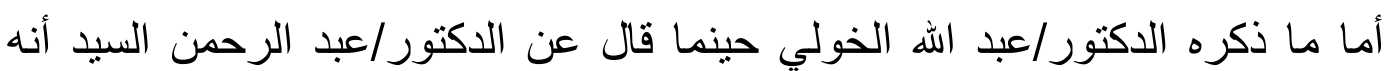

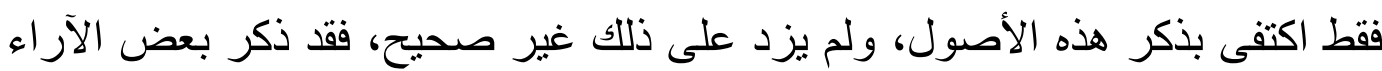

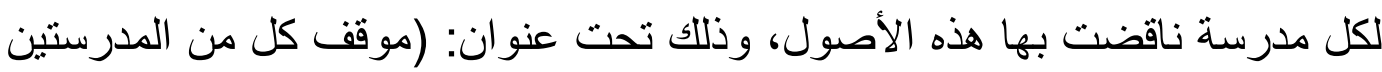

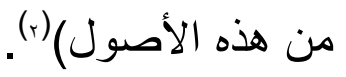

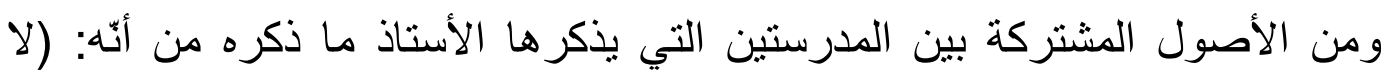

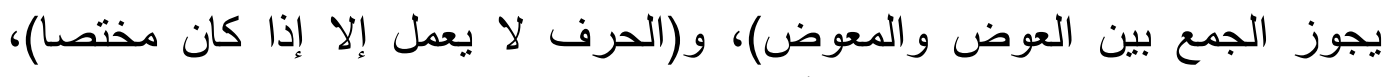
و(الفروع تنحط دائما على درجة الأصول ) و وغير ها.

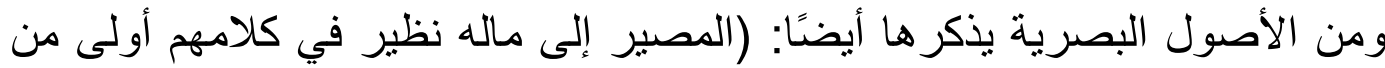

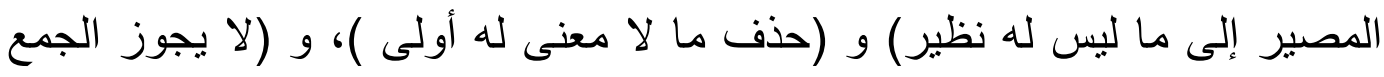
بين علامتي تعريف)، وغير ها. لها.

ومن الأصول الكوفية التي ذكرها: (كثرة الاستعمال تجيز ترك القياس، والخروج

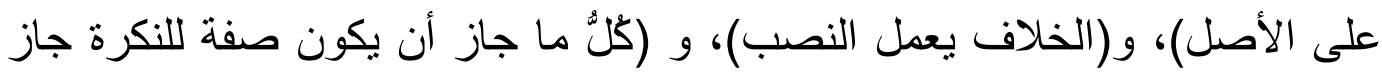
أن يكون حالا للمعرفة).

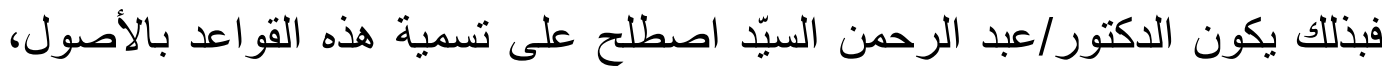
ويعود السبب في ذلك إلى أنّه درس هذه القو اعد التي تضمنها كتاب الإنصاف في التي

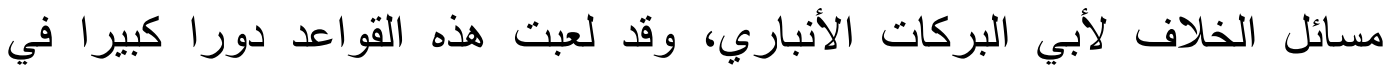




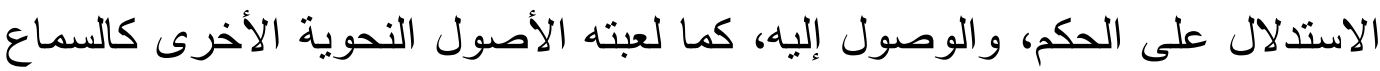

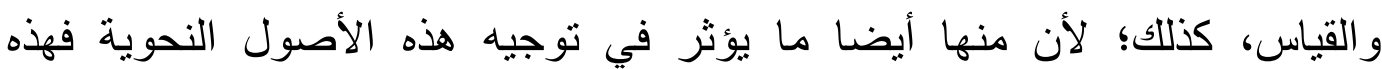

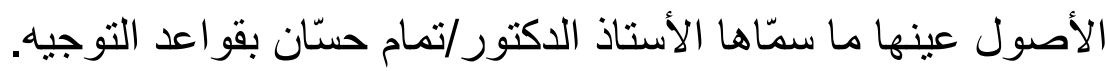

لذا فعندما تعرض لبعضها د. محمد خير الحلو اني في حديثه ذكر أنها وجه من وجوه

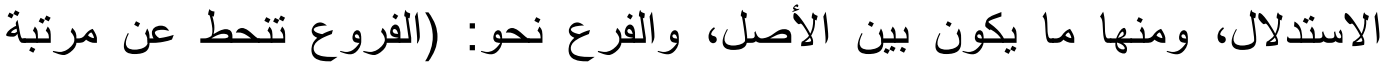

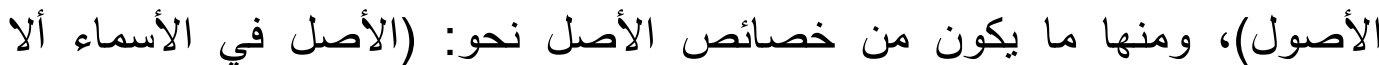

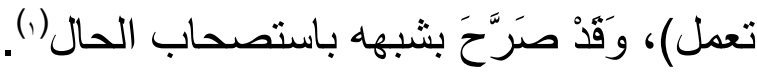

\section{r- أ.د.تمام حسّان في كتابه (الأصول) واصطلاح قواعد التوجيه:}

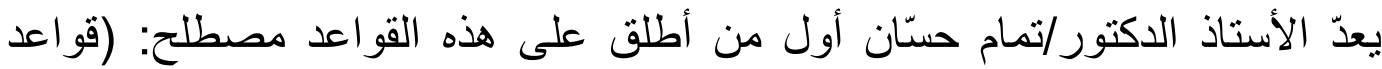

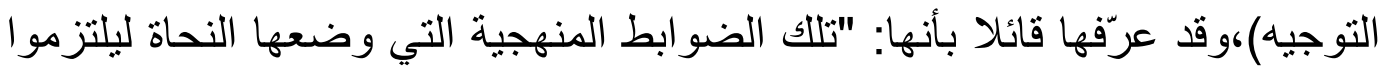

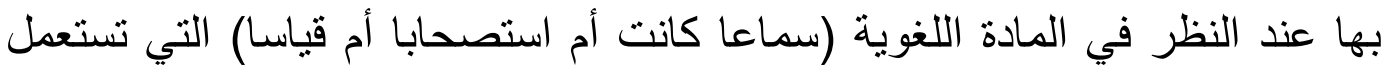
لاستنباط الحكم"(r). (ب)

و الملاحظ في هذا التعريف أنّ قواعد التوجيه تصاحب أصول النحو من حيث إنها

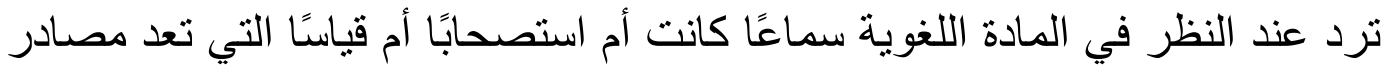

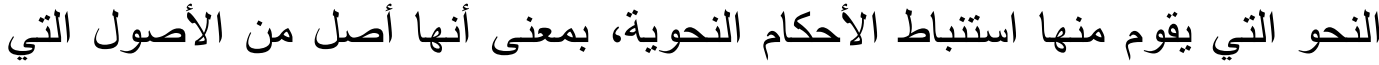

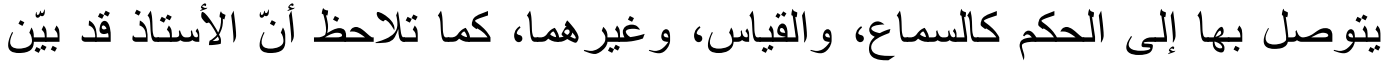

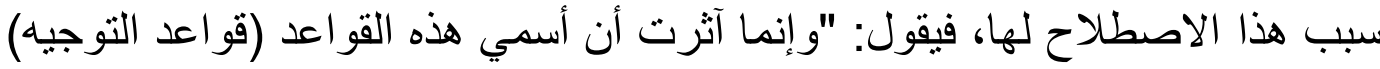

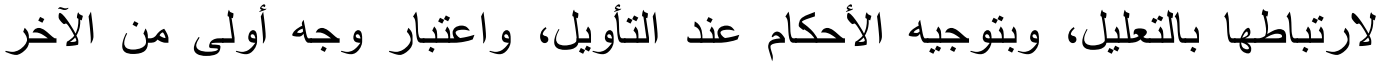

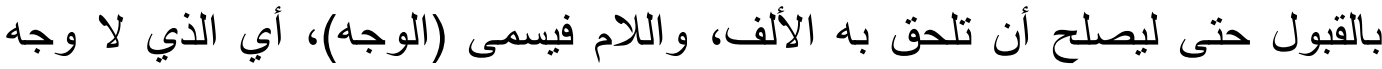

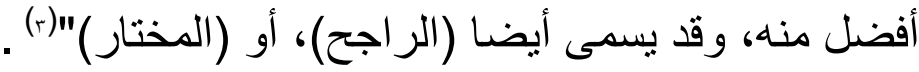

الواضح أن سبب هذا الاصطلاح يعود عند الدكتور/تمام حسَّان إلى تعليل الحكم أوَّلا،

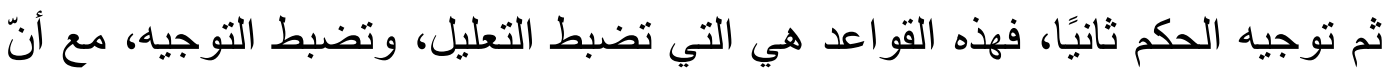

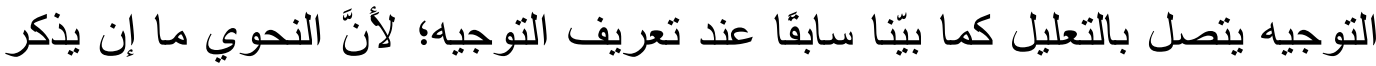

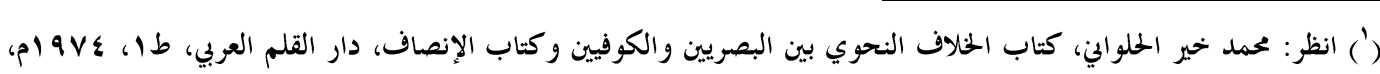

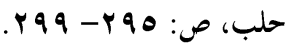

(') أنتام حسان، كتاب الأصول، ص:

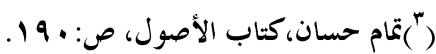


الحكم يذكر معه ما يتعلق بالحكم من تعليل، وكل ما يصحبه من استدلال على الحكم، وترجيح بين الأحكام و غيره.

ونرى أنَّهُ على الرغم من التلازم بين التوجيه والتعليل ينبغي أن نجعل التعليل

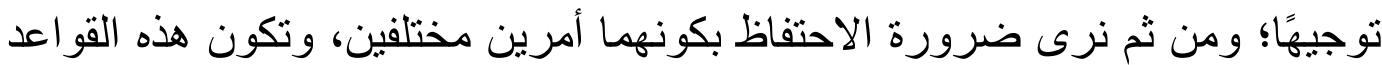
متصلة مرة بالتوجيه، وأخرى بالتعليل، وثالثا بالاستدلال...إلخ (1).

إلا أنَّ الدكتور حينما نطرَّقَ للتفريق بين الددرستين البصرية، والكوفية ذكر مجموعة

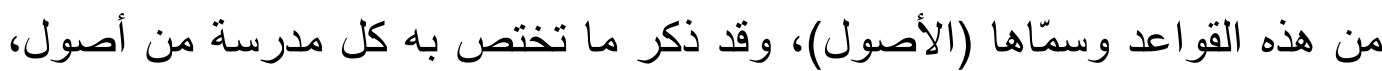

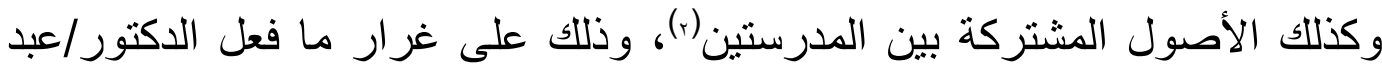

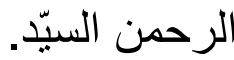

كذلك حينما عرض للاستدلال ذكر الأصول التي تضبط الدليل النحوي(r)، وهي عينها التي سمّاها فيما بعد بقو اعد التوجيه.

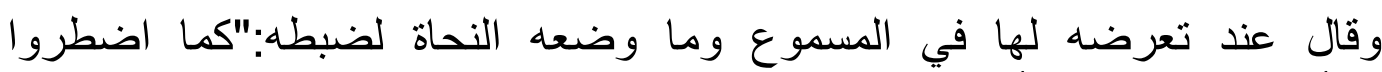

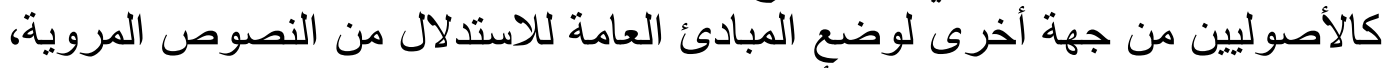

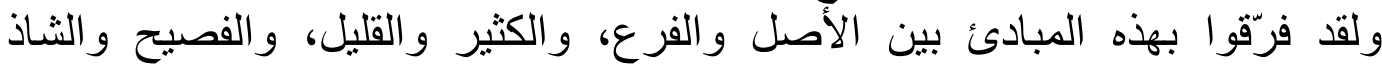
المحفوظ و غير المحفوظ إلخ.

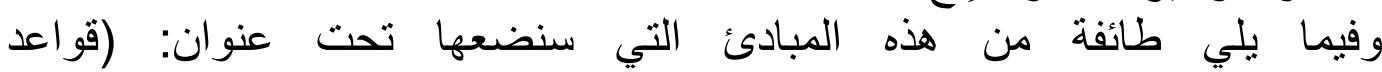

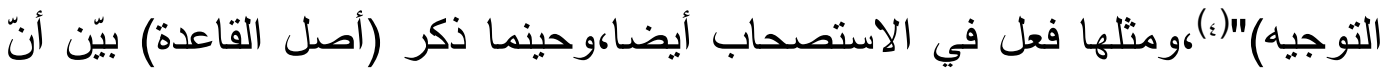

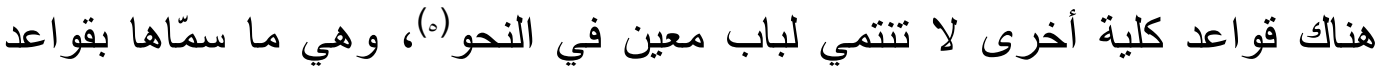

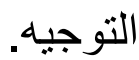

هذا يعني أيّه اصطلح عليها بقو اعد التوجيه، وإن كنت أراها قو اعد كلية، وهذا يؤيد أنيا

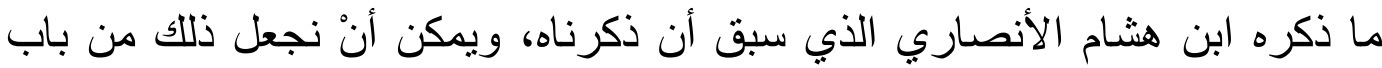
التغليب أو تسمية الكل باسم الجزء الانهي

(') لذلك اعترض الدكتور / الحولي على قول الأستاذ تقام حسّان عن هذه القواعد أتها لاستباط الحكم في أحد اعتراضيه، انظر قواعد

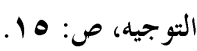

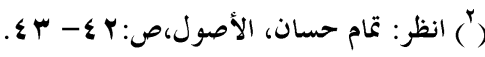

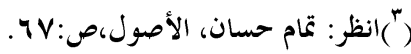

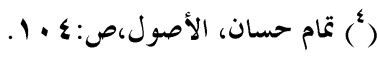

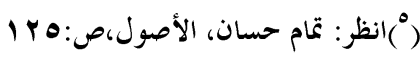


أمّا إذا سمّيناها أصو لا كما هي عند الدكتور/عبد الرحمن السيد، والأنباري، و غير هما

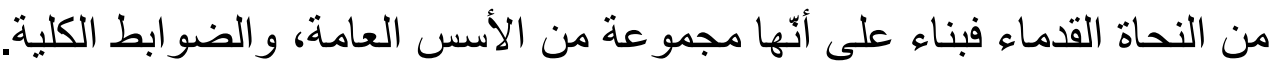

ץ- د.محمد سالم صالح في رسالته (أصول النحو.دراسة في فكر الأنباري): تابع الدكتور/محمد سالم الدكتور/تمام حسّان اصطلاح قو اعد التوجيه، وقدَّم تعريفه

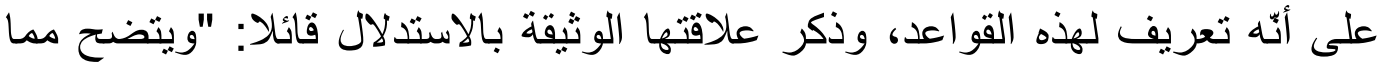

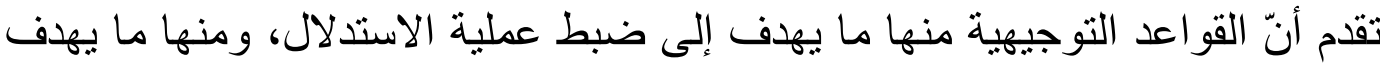

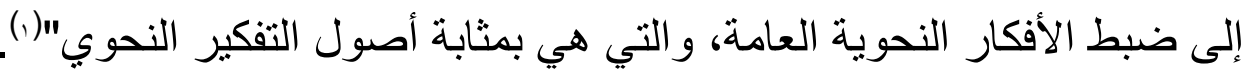
وهو يقصد بالأفكار النحوية العامة: (العامل- الحذف- الفصل- الحمل- الإعراب-

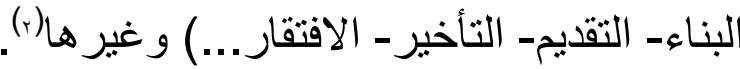

وكلُ ما ذكر من هذه الأفكار تظهر في أثناء توجيهات النحاة للأحكام المختلفة، أمَّا ما

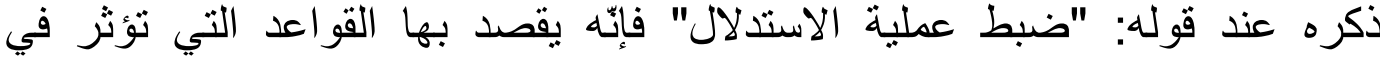

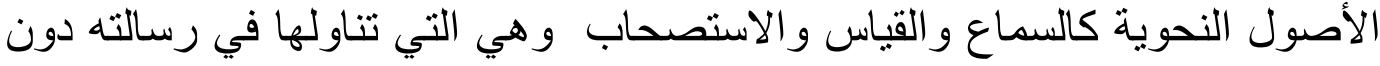
الأولى المتعلقة بالفكر النحوي عمومًا.

وتعليقنا على موقف د.محمد سالم من جعله هذه القو اعد أصو لا للتفكير النحوي بتمثل

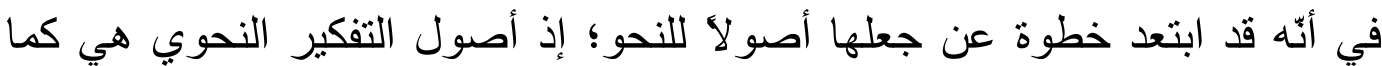

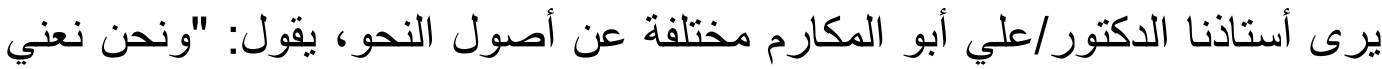

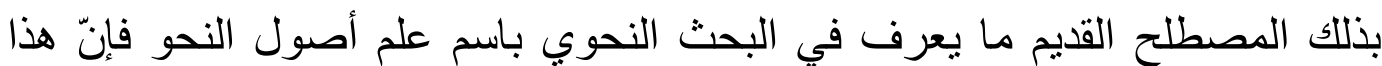

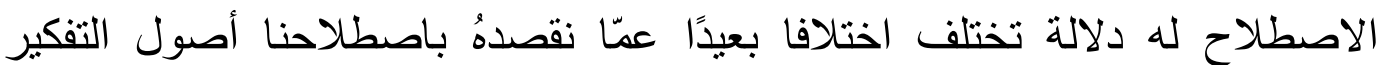

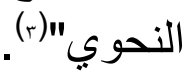

ونتير إلى أنّه جعل العامل والحذف والفصل و الحمل وغير ذللك من المفاهيم التي

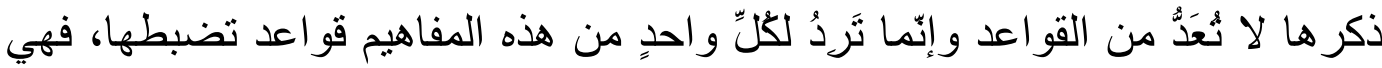

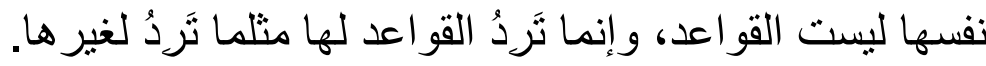

ع - د. عبد الله الخولي في كتابه (قواعد التوجيه في النحو العربي):

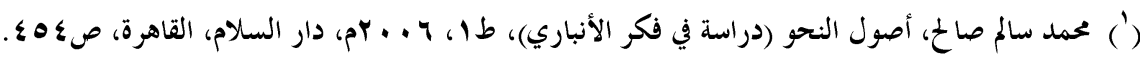

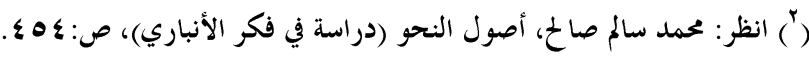

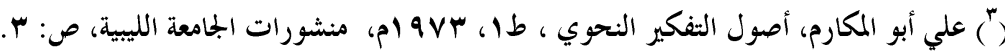




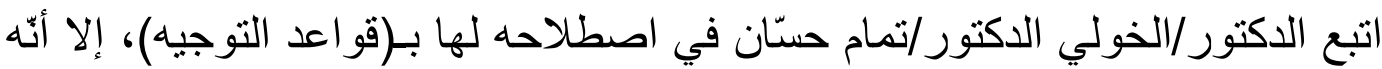

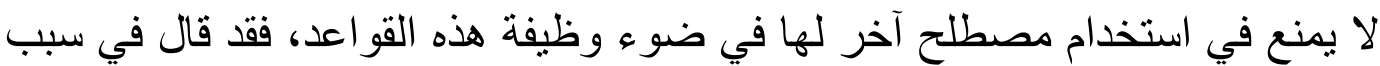

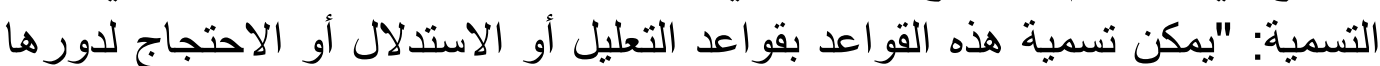

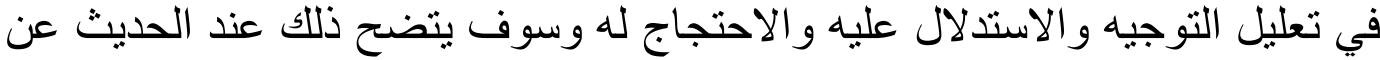

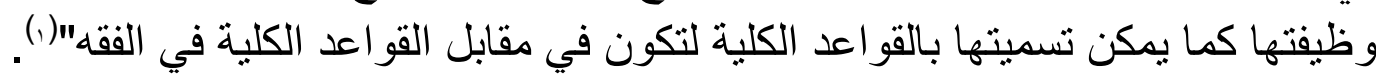

ولا شكَّ أنَّ هذا التجوّز في التسمية يعود لوظيفة قواعد التوجيه التي حدّدها الدكتور/الخولي في أربعة وظائف، كذللك النظر لها يقابلها في الفقه الإسلامي؛ لأن النان كثير ا من مصطلحات أصول النحو نشأت متأثرة بمصطلحات الفقانه ويرجع سبب اتباعه للأستاذ تمام حسّان في تسميته لها بـ (قو اعد التوجيه) إلى: ا ـ الارتباط بين التوجيه و غيره من تعليل واستدلال...إلخ، سواء أكانت لتعليله،

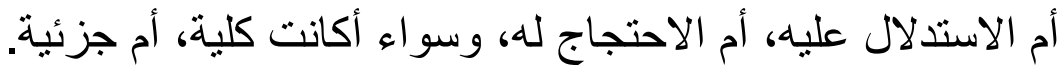

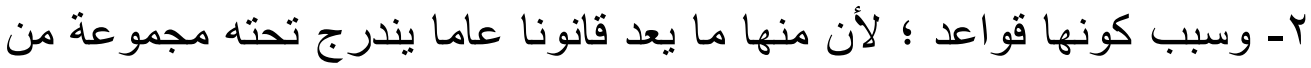
الجزئيات المشتركة في الخصائص و والسمات، وقد عبّر عنها النان النحاة عن شيء

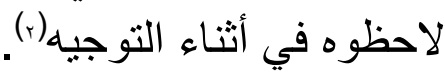

وهو مع هذا يصرّح بأنها من أصول النحو؛ لأن منها ما يتعلق بالقياس، ومنها ما

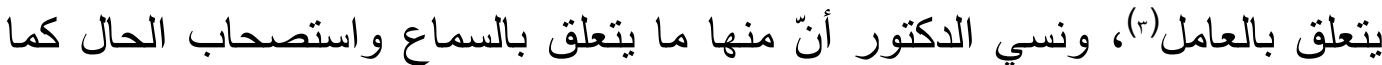

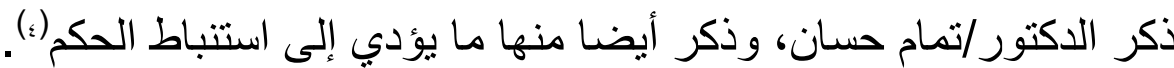

و الذي يتضح أنّه حينما عرَّف قو اعد التوجيه قائلا: "هي قو انين تضبط ما ذكره النحاة من توجيه وتنظر له، وقد صيغت لتقريره أو تعليله أو الاستدلال عليه أو الأن الاحتجاج

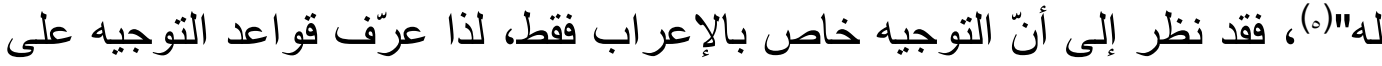
أساس التوجيه الإعرابي، وهذا مما لا شك فيه يلغي دور قواعد التوجيه في التأثير

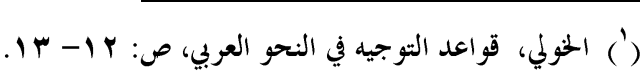

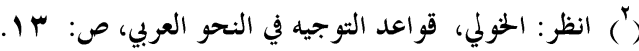

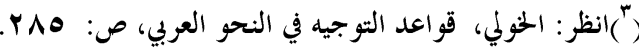

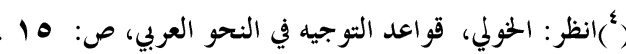

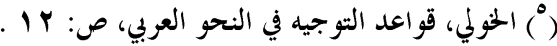


على الحكم والاستدلال بشكل عام؛ لذا اعترض على الدكتور/تمام حسّان في تعريفه،

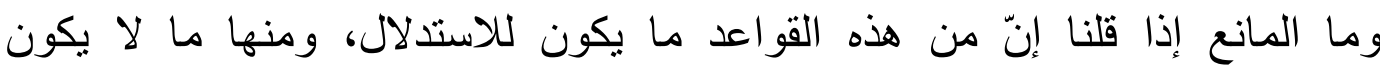

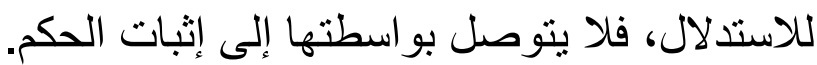

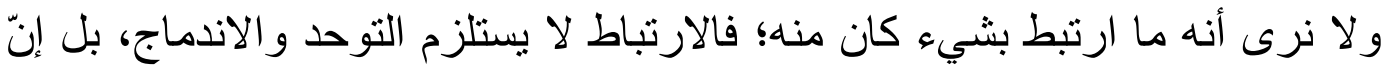

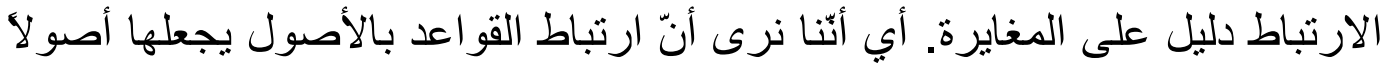

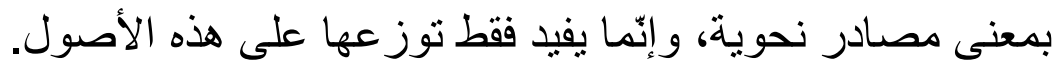

هـ د. عصام عيد فهمي في كتابه (أصول النحو عند السيوطي بين النظرية

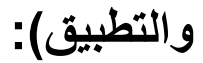

يعدٌّ د. عصام عيد من الذين اتبعوا أ.د.تمام حسّان في اصطلاح (قواعد التوجيه)،

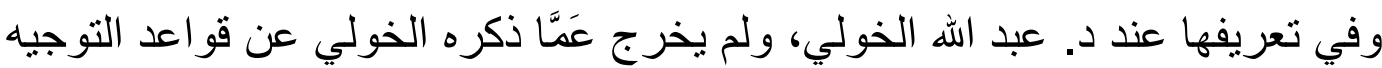
سوى استخراجه لهذه القواعد من كتب السيوطي الذي هو الذه محلّ بحثه في كتابه،

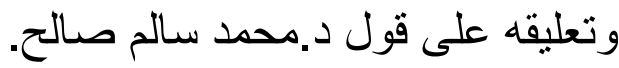

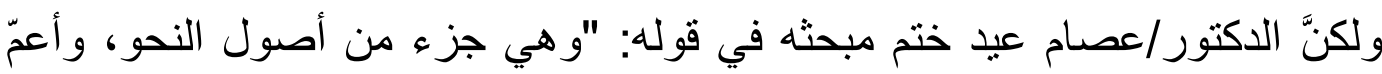

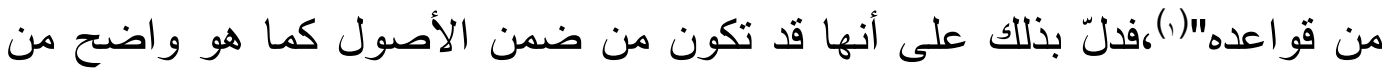
قوله.

דـ د.محمد حسن الجاسم في كتابه (القاعدة النحوية):

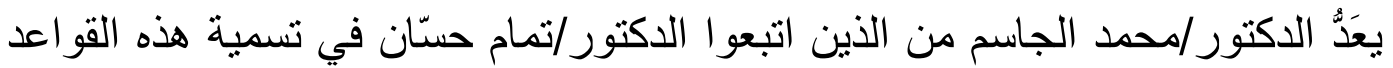

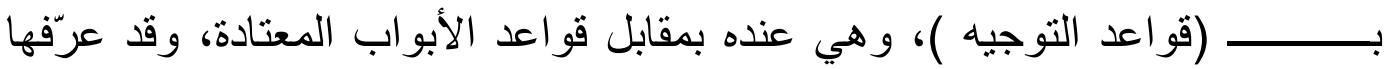

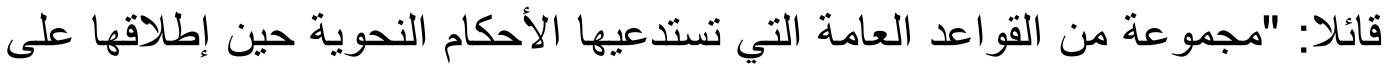
عناصر النظام التركيبي في قضايا التحليل النحوي.

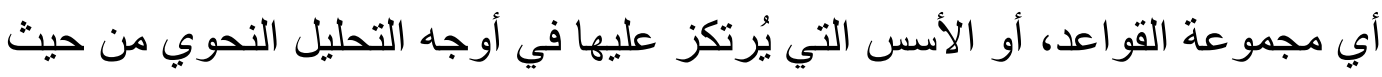
الترجيح والتضعيف والرفض؛ لأن هذه الأسس التوجيهية هي الوبهي الوسيلة التي تمكن

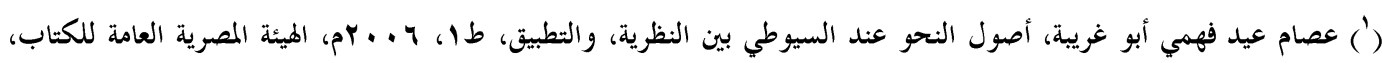

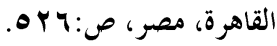


المحلل من تحديد الوجه المناسب، وتتعلق بقضايا السماع أو الأصل أو آراء النحاة أو

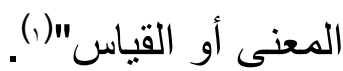

و هذا التحليل النحوي عنده هو التوجيه الذي تحدثنا عنه سابقا؛ لأنه ذكر أنّ ارتباط

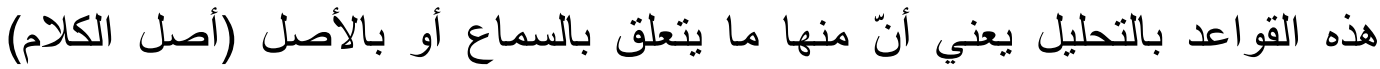

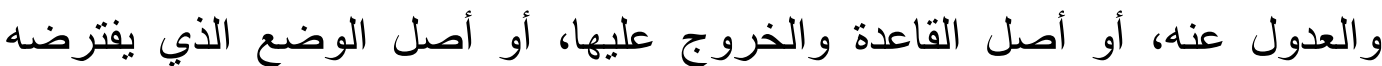

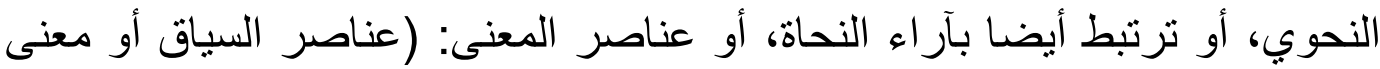

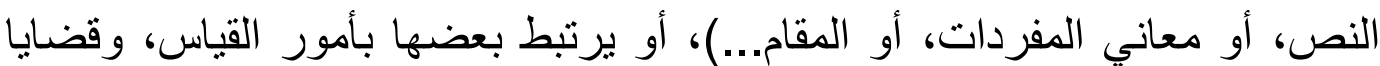

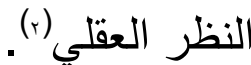
وَكُلْ ذلك حينما يعرضه النحوي في سياق كتبه فهو يقوم بعملية التوجيه، فهذه القو اعد هي الضابطة لهذه التوجيهات، و التحليلات لدى النحاة. و الخلاصة مما سبق أن الباحثين المعاصرين اصطلحو ا علي تسميتها بـ (الأصول)(r)،

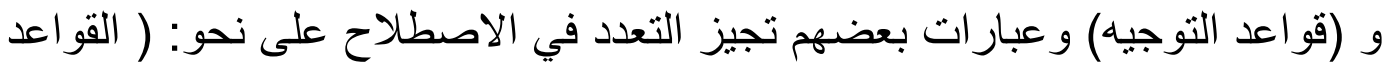

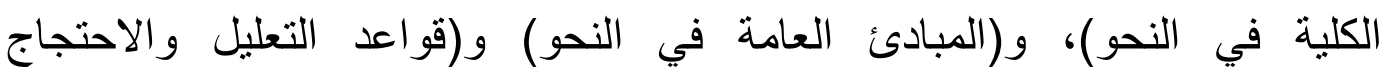

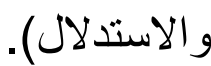

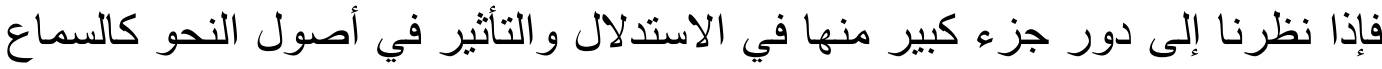

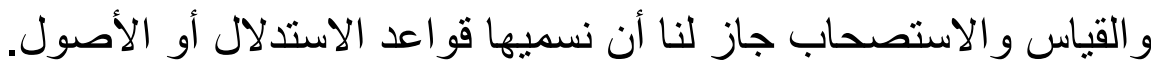

$$
\begin{aligned}
& \text { (') الجاسم، القاعدة النحوية (تحليل ونقد)، ص:هب. }
\end{aligned}
$$

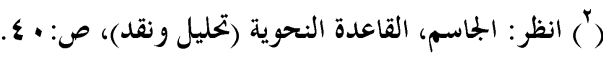

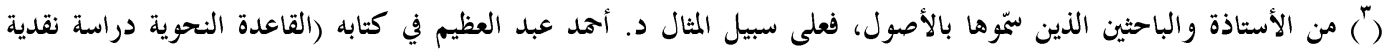

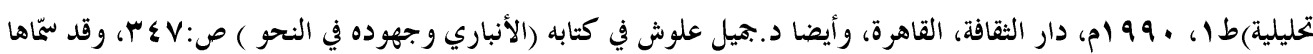

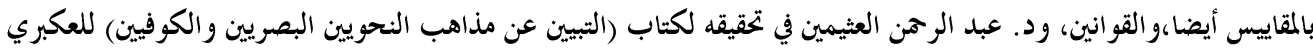

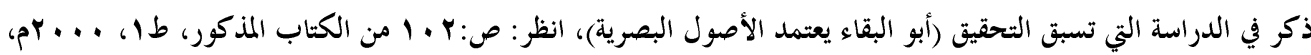

$$
\text { مكتبة العبيكان، المملكة العربية السعودية. }
$$

كذلك د. محمد بن علي العمري، في كتابه (قياس العكس في الجدل النحوي العهائ عند ألبي البركات الأنباري) رسالة دكتوراه

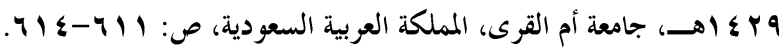

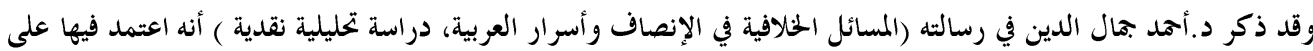

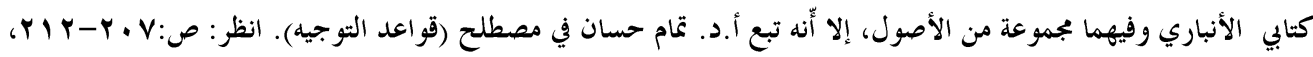

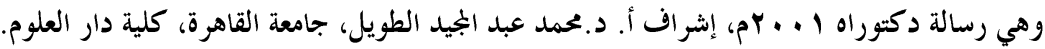


و إذا نظرنا إلى سياقها التي وضعت له و هو الذي يكون في الغالب سياق تعليل يمكن أن نسميها (قو اعد التعليل).

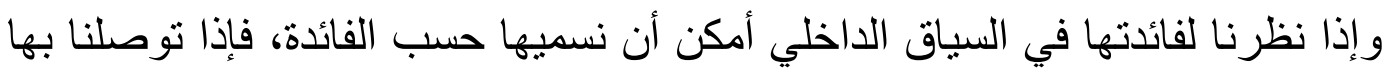

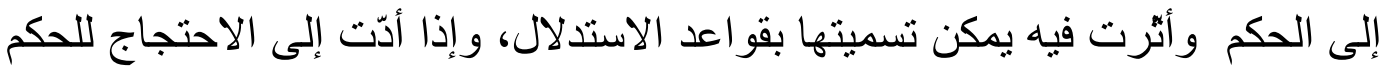

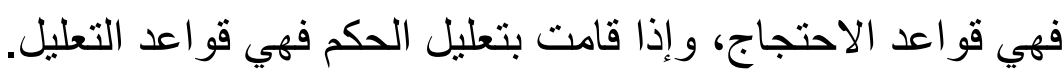

و إذا نظرنا إلى كل توظيفها في تحديد الأوجه النحوية والترجيح بينها أمكن تسميتها بقو اعد التوجيه؛ لأن التوجيه يشمل كل ما سبق ذكره

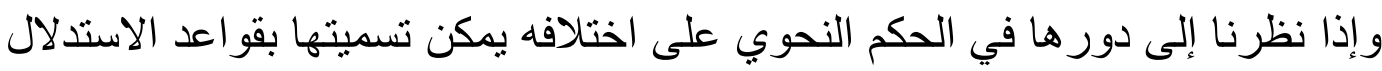

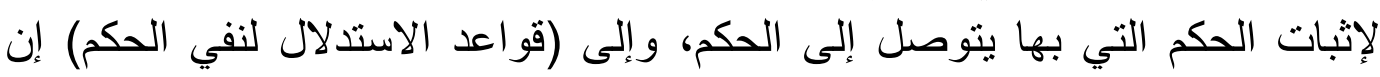

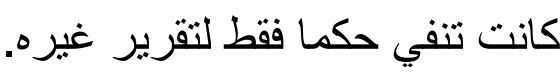

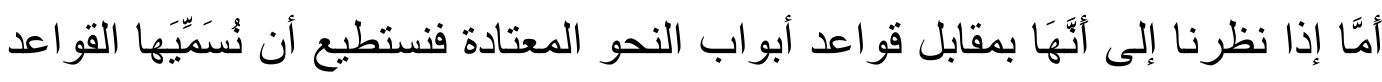

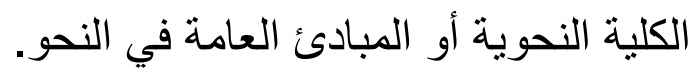

على أنّا في هذا البحث سوف نستخدم اصطلاح (قواعد التوجيه) ؛ لأنه هو الأكثر

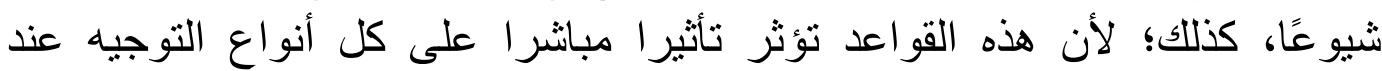
النحاة، سواء أكان توجيها إعران ابيا، أو غيره.

ثالثًا: مكانة قو اعد الثو جيه بين الأصول النحوية:

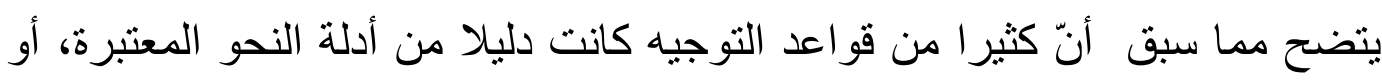

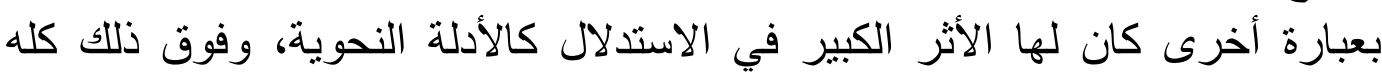

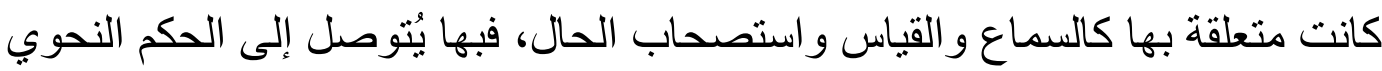

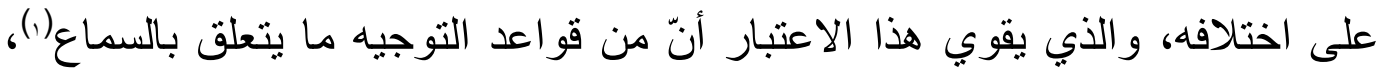

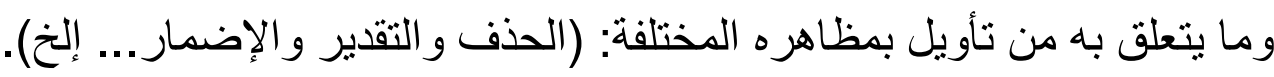




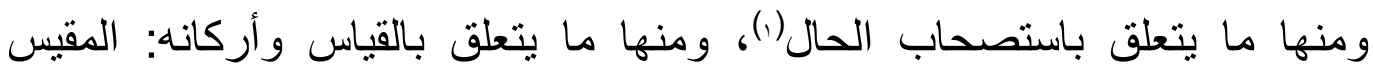
(الأصل)، و المقيس عليه(الفرع) و الجامع أو العلة، ثم الحكم، ومنها ما يتعلق بالعامل العاله

فمن هذه القواعد على سبيل المثال:

1 - من قواعد التوجيه المتعلقة بالسماع:

ـ الحمل على المعنى كثير في كلامهم(r).

r- من قواعد التوجيه المتعلقة بالتأويل:

- ما لا يفتقر إلى تقدير أولى مما يفتقر إلى تقدير (؛). r- من قواعد التوجيه المتعلقة باستصحاب الحال:

ـ الأصل في الأسماء ألا تعمل(ه). ـ الأصل في الحروف ألا تدخلها الإمالة(.). ع- من قواعد التوجيه المتعلقة بالقياس:

ـ الفروع تتحط عن درجة الأصول(v) هـ من قواعد التوجيه المتعلقة بالعامل والمعمول:

ـ العامل سبيله أنْ يقدر قبل المعمول(^).

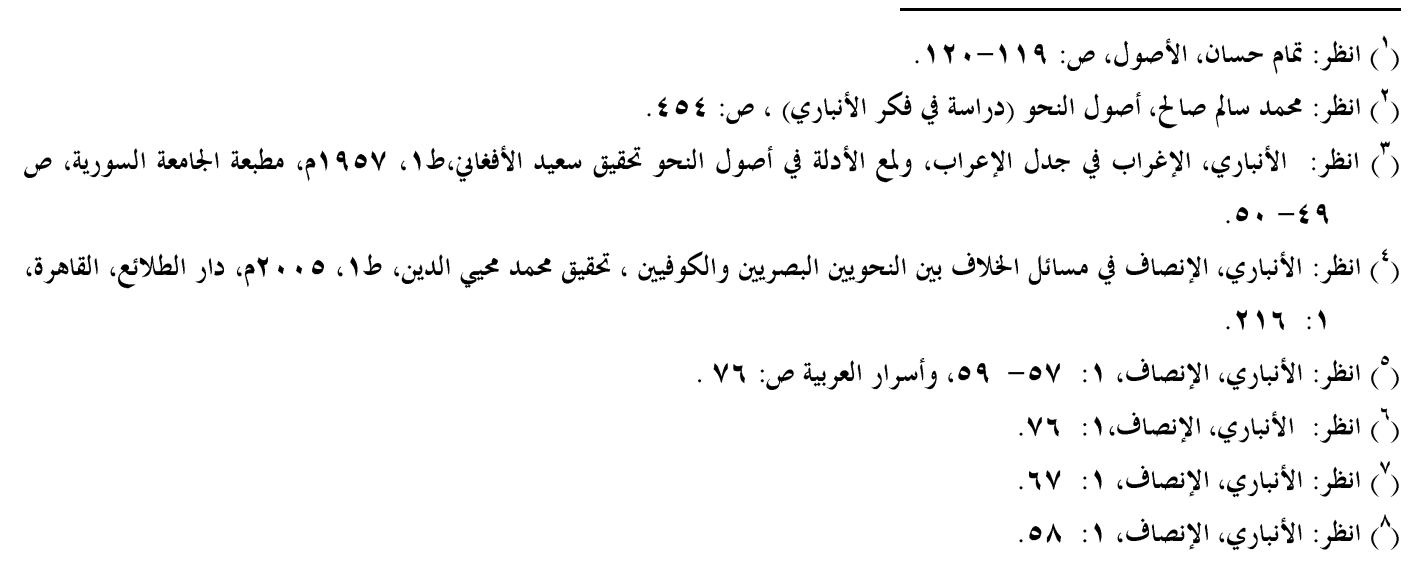




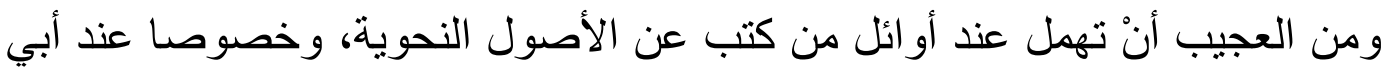

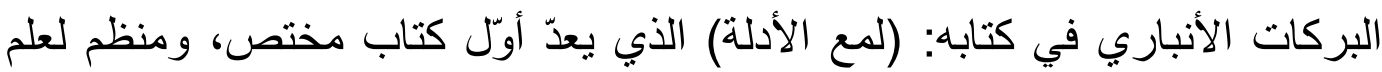

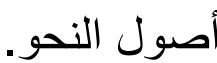

وهذا يزول إذا عرفنا أيّه كتاب مختصر، ولا يمكن أن يتعرض لكل شيء، وهو

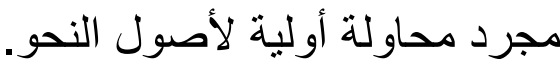

لكن في الحقبقة قد ذكرها الأنباري صراحة ضمن أصول النحو، فقد ذكر في

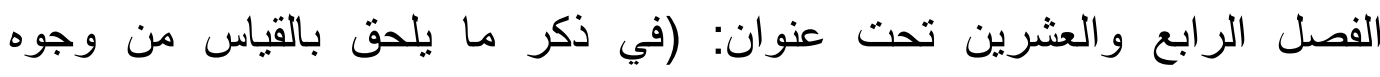

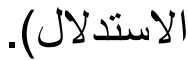

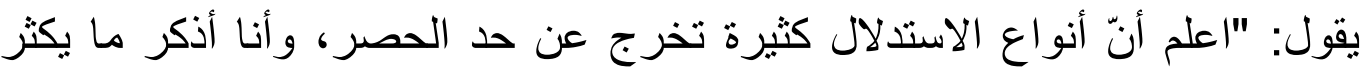

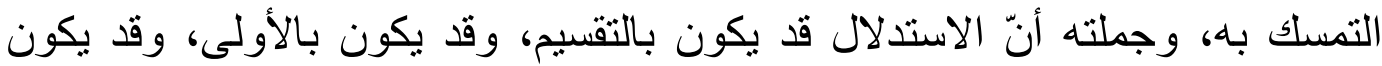
بيان العلة، وقد يكون بالأصول" (.).

غير أنَّ الأنباري لم يحد هذا النوع من الاستدلال الملحق بالقياس، ولكتّه اكتفى

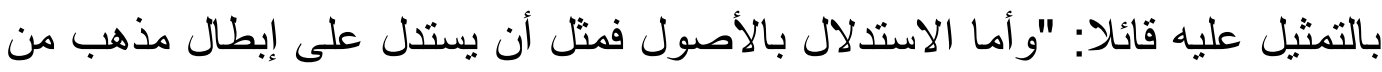

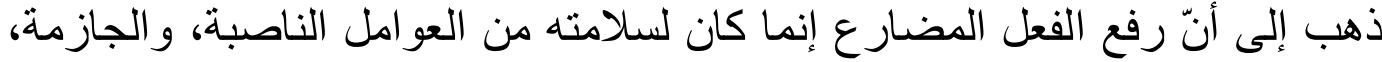

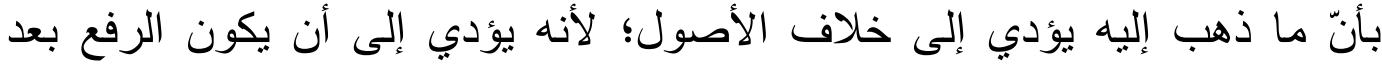

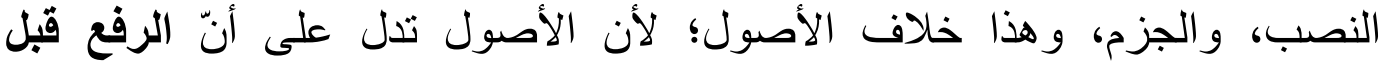

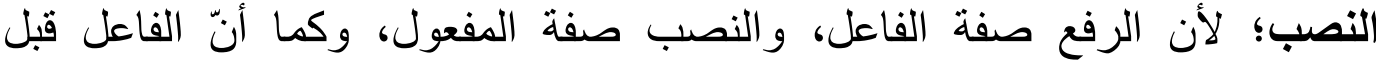

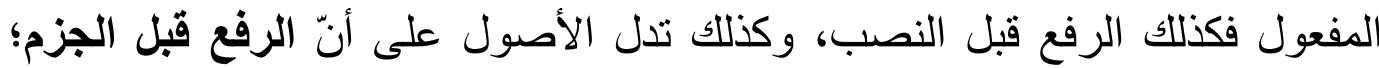

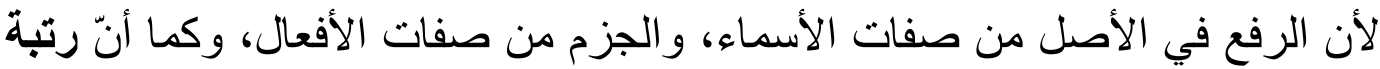

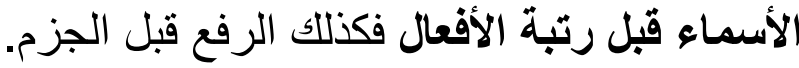

فإن قيل: فهب أنّ الرفع في الأسماء قبل الجزم في الأفعال، فلمَ قلتم إنّ الرفع في الأفعال

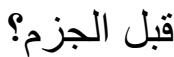
قلنا: ؛ لأن إعراب الأفعال فرع على إعراب الأسماء، و إذا ثبت ذللك في الأصل فكذللك في الفرع ؛ لأن الفرع تبع الأصل"(r).

$$
\begin{aligned}
& \text { (') الأنباري، الإغراب في جدل الإعراب، ص: Irv }
\end{aligned}
$$

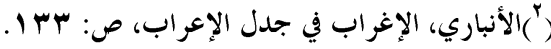




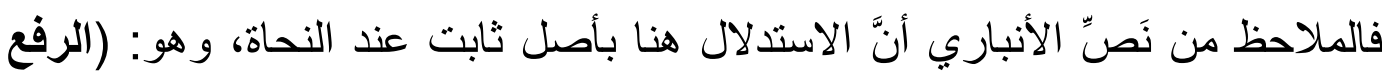

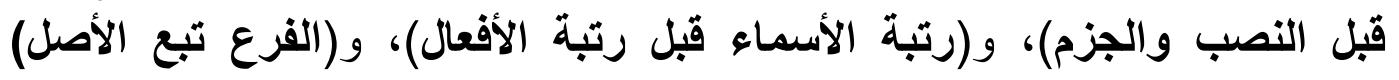

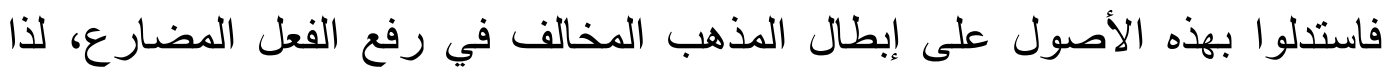
فاستدل به على نفي الحكم فهي دليل من أدلة الاستدلال النحوي.

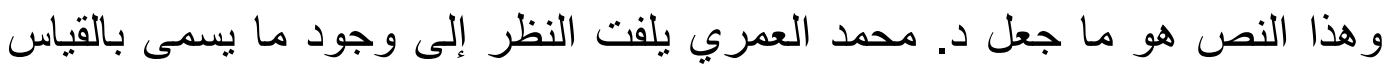
بدلالة الأصول الذي يرجع بدوره إلى قياس الطرد، وإثباته في رسالته الحديثة (1).

$$
\text { رابعًا: نشأة قواعد التوجيه في النحو العربي: }
$$

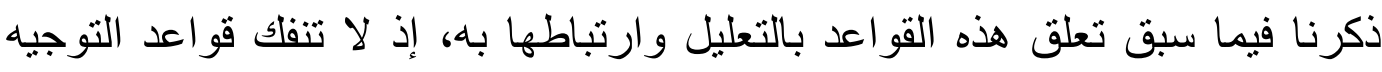

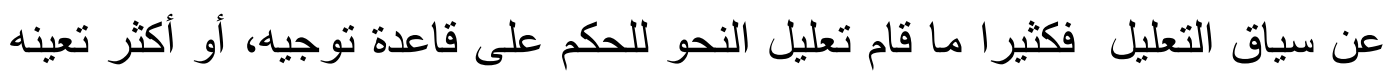

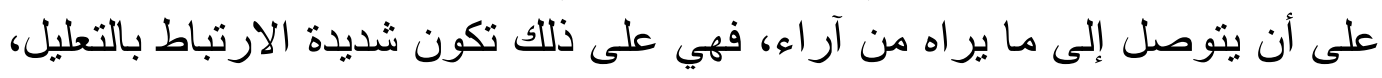

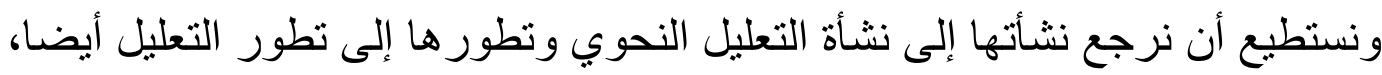
وهذا ما سنلاحظه فيما يلي.

وترجع بداية التعليل النحوي "في الوقت الذي يضعون فيه القواعد يبررون هذه

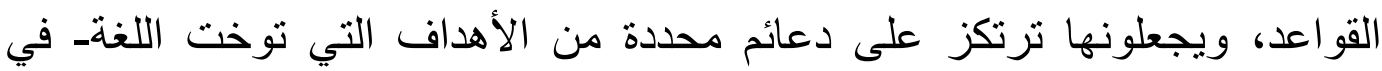

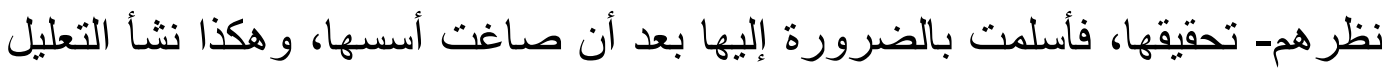
في النحو العربي"(r).

وهذا يعني أنّ التعليل نشأ بعد وضع القواعد، فلم يكن له الأثر المباثر في

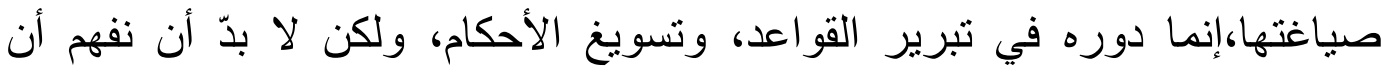

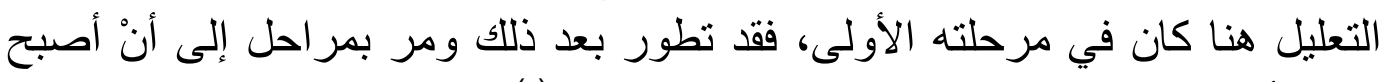

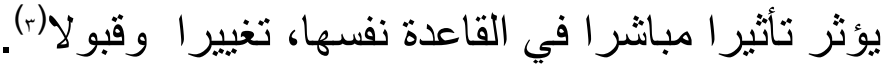

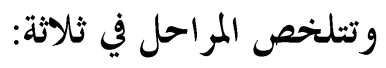

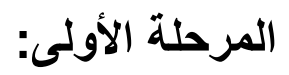

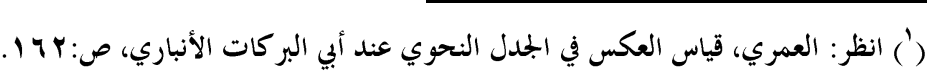

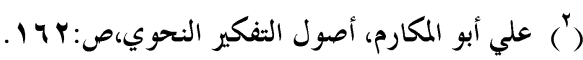

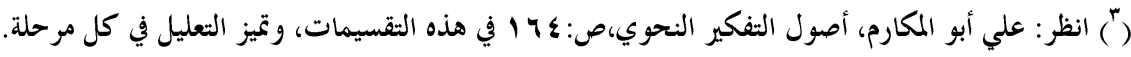




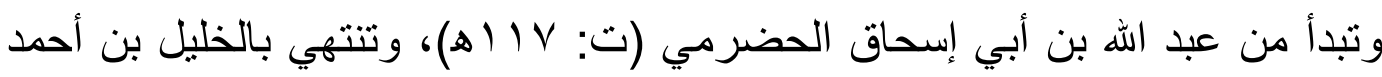

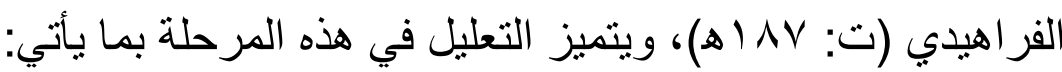

|- جزئية موضوع التعليل، ونظرته، بحيث يتناول قضايا جزئية، ومسائل فرعية،

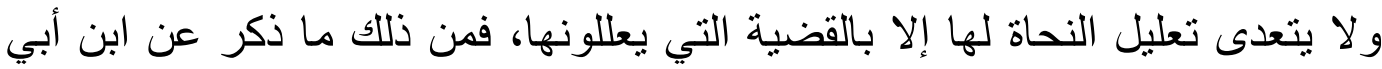
إسحاق حينما اعترض على الفرزدق في قوله:

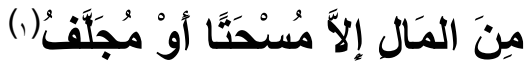

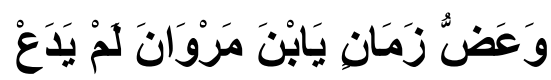
فقال له: بم رفعت مجلف؟ فقال له: بما يسوؤك، و ينوؤك.

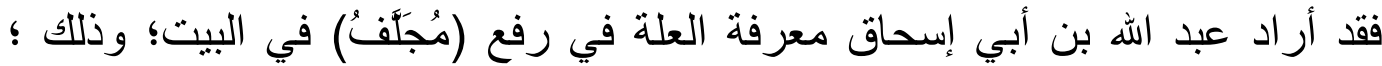

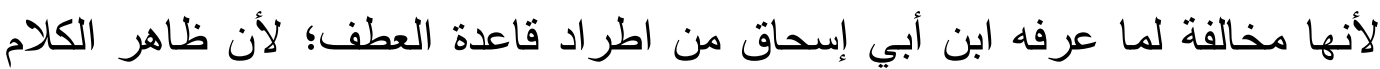

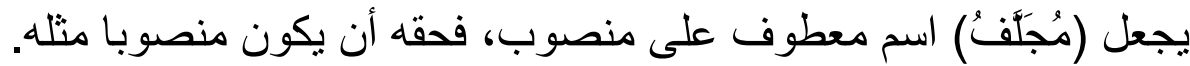

r- تو افق التعليل مع القو اعد التي توصل إليها النحاة، واتساقها معها، و التعليل بذلك التكان

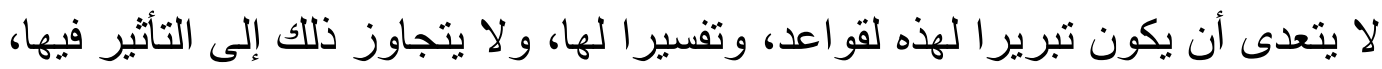

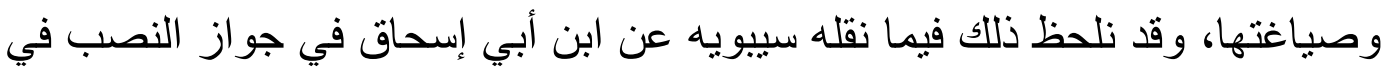

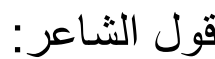

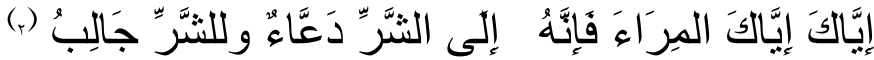

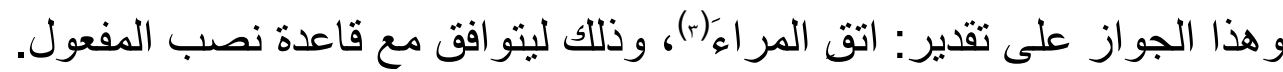
r- الوقوف في التعليل عند النصوص اللغوية، فهي وضعت من أجل تبرير هذه النصوص، وتفسير ها لا أكثر، لذا لا يتنزه بعض نحاة هذه الفترة عن تخطئة العرب،

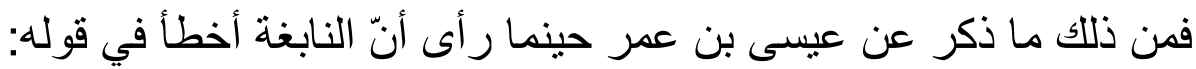

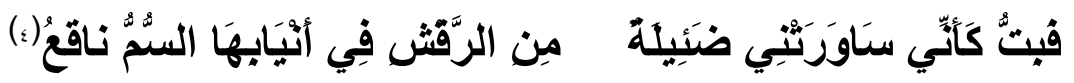

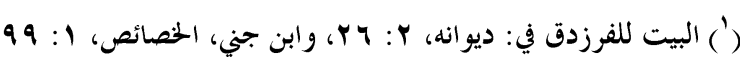

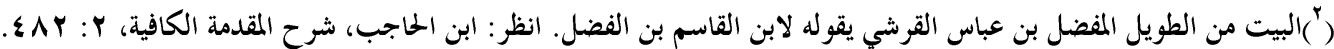

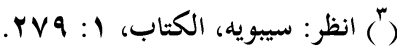

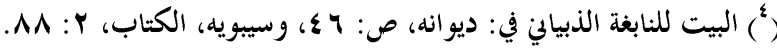


فكان برى أنّ حق (ناقع) النصب، وقوفا على النصوص اللغوية المطردة، فمن خالف

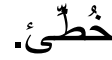

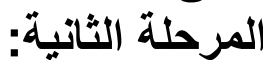

وتبدأ هذه المرحلة من الخليل بن أحمد الفراهيدي()، وتنتهي بالزجاج ( • (اسهـ)،

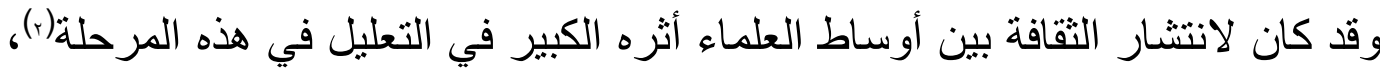

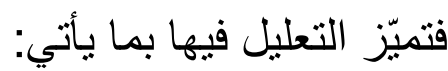

1 - عدم الاقتصار على تعليل الظواهر اللغوية والنصوص المروية، بل شمل تعليل

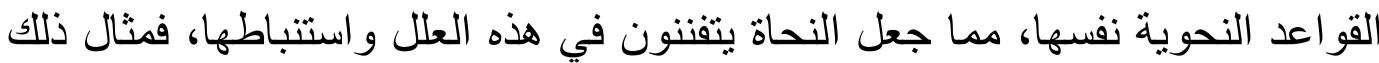

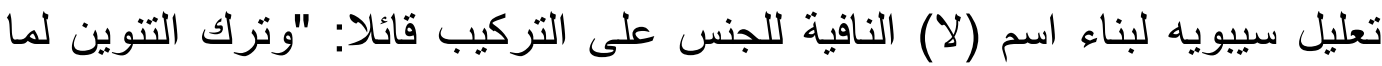
تعمل فيه لازم؛ لأنها جُعلت وما عملت فيه بمنزلة اسم واحد نحو خمسة عشر "(م). كذللك المبرد علل رفع الفعل المضارع قائلا: "اعلم أن هذه الأفعال المضار عة ترتفع

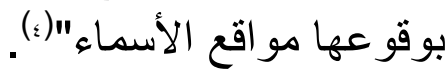

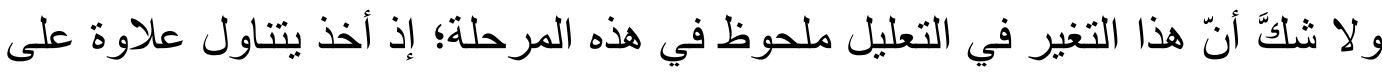
ما تتاوله في المرحلة الأولى، القو اعد النحوية النحية نفسها.

(') الحق أنّ الحليل هو على رأس هذه الفترة ؛ لأن تعليلاته كثيرا ما كان يتعرض فيها إلى تعليل القواعد فمنها تعليله لحذف الجار، قال

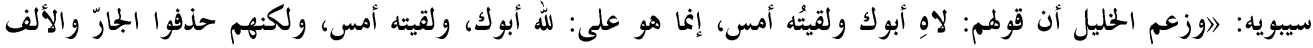

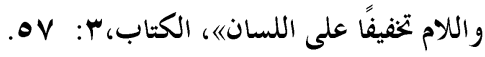

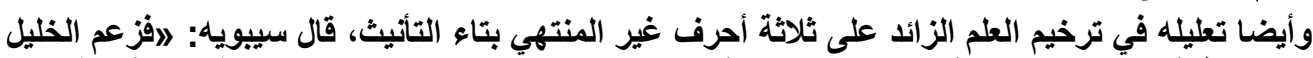

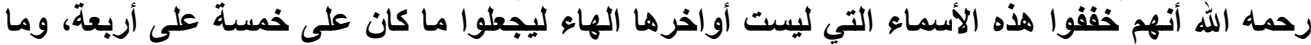

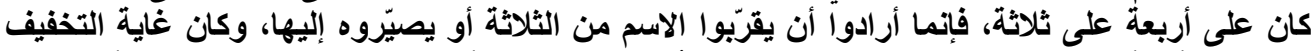

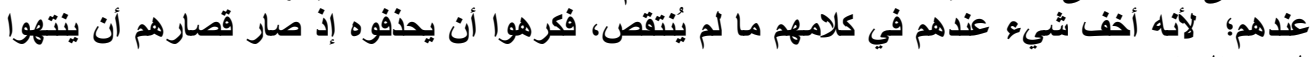

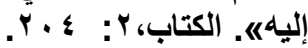

ولكن أ.د. علي أبو المكارم يرى أنّ هذه الفترة تبدأ بتلاميذ الحليل، وما المانع من اتصاف تعليلاته بتعليلات المرحلة الأولى، و وبتعليلات المرحلة الثانية.

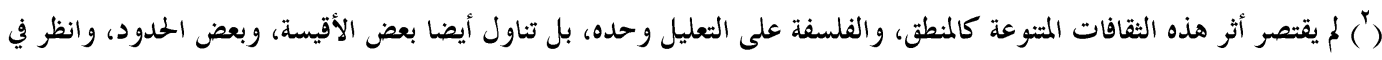

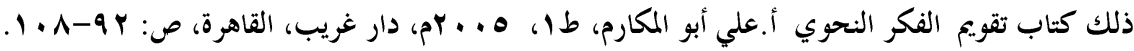

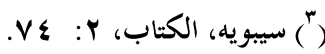

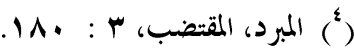


r- أصبح التعليل لا يقتصر على بعض الظواهر الجزئية فقط، بل تجاوزها ليتناول

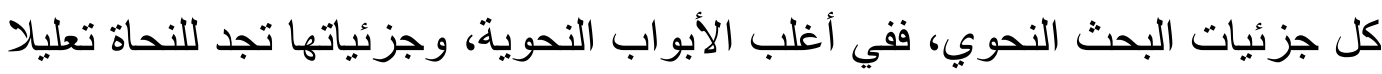

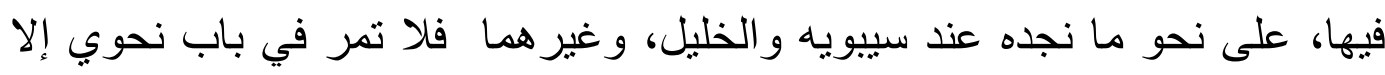

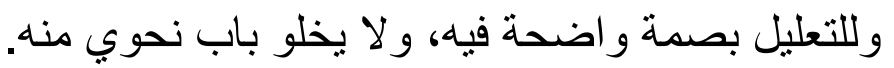

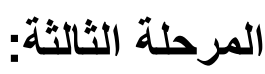

تبدأ هذه المرحلة من ابن السراج (ت:بآ آهـ)، وتثمل جميع العصور اللاحقة لها

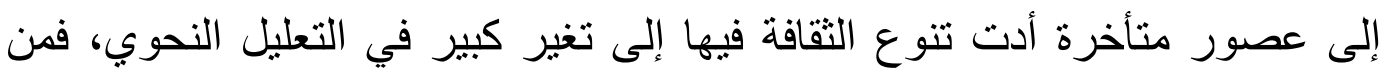

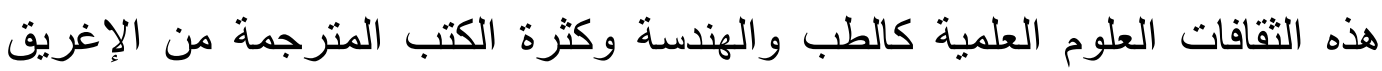

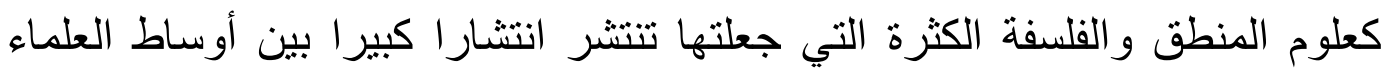

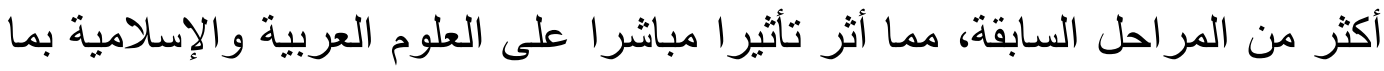
فيها النحو (1)، مما جعل التعليل يتميز في هذه المرحلة بما بأتي:

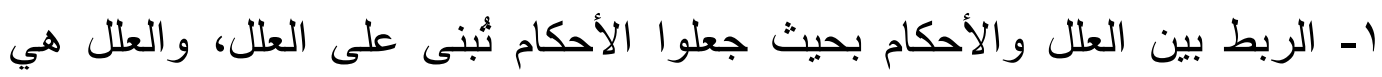

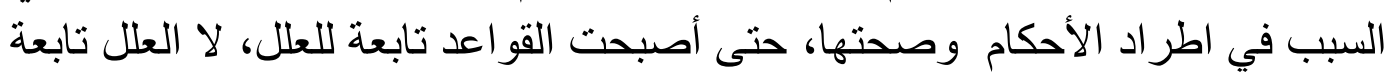

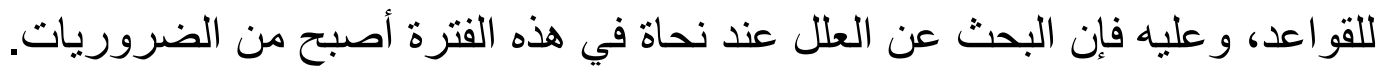

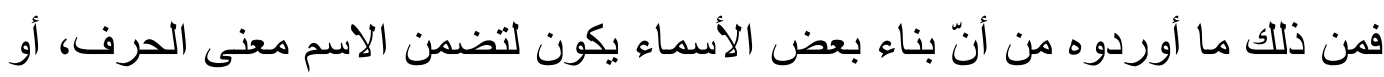

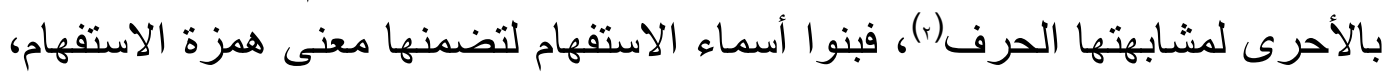

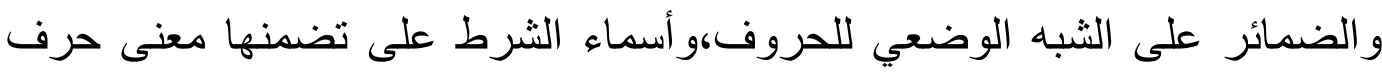

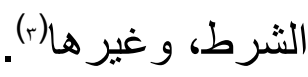

و هذا التعليل لا شك أنه بربط بين أبو اب متعددة كالاستفهام و الثرط و الإشارة...إلخ، و هو سبب رئيس للبناء بحيث لا لائل يوجد حكم البناء إلا بها.

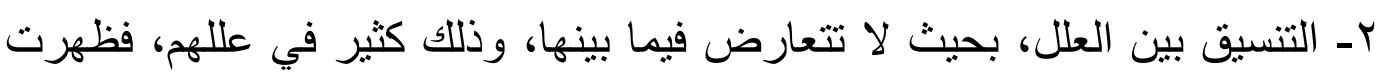

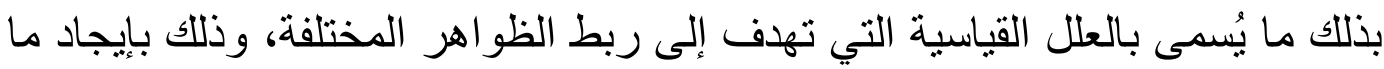

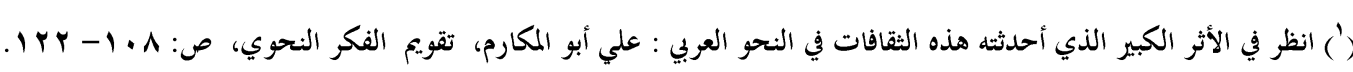

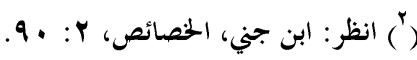

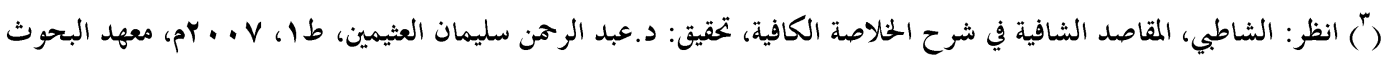

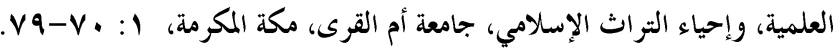


بينها من صلات قد تربط بعضها ببعض()، وقد ذكرها الزجاجي قائلا: "فأما العلة

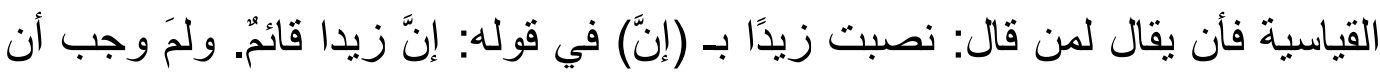

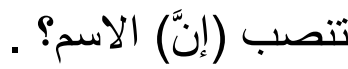

فالجواب في ذلك أن يقول: لأنهاهوأخواتها ضارعت الفعل المتعدي إلى مفعول،

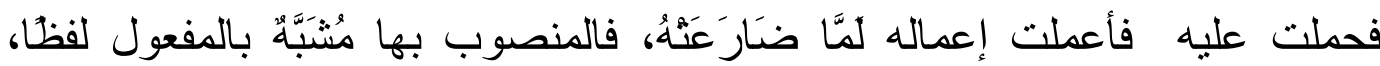

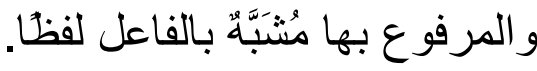

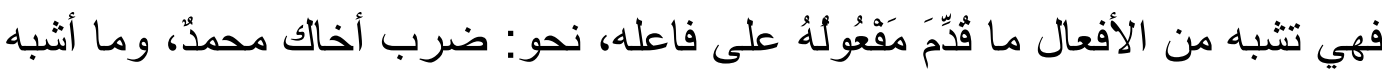
ذلك" (r)

على أنّه ظهر أيضا ما يُسَمَّى بالعلل الجدلية، وهي تعليل للعلة القياسية، وتبرز إلى إيلى

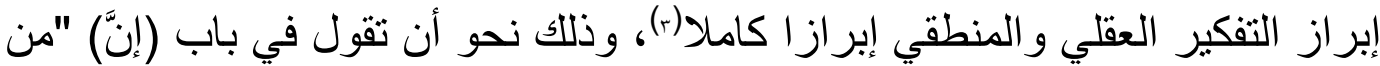

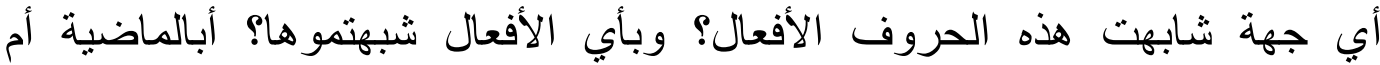

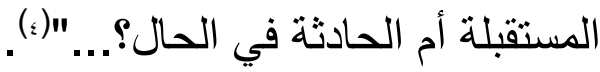

و لا شكَّ أنَّ قو اعد التوجيه قد تأثرت بما تأثر به التعليل، وتطورت بنطوره، لذا نجد

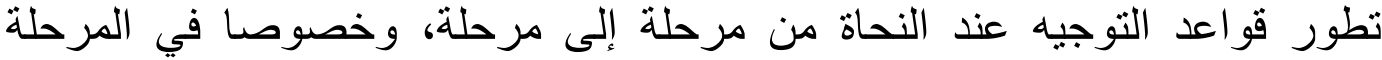
الثانية، و المرحلة الثالثة، ويشمل هذا التطور ما يلي:

أولاً: بداية ظهور قو اعد الثوجيه:

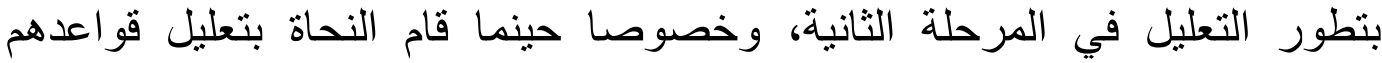

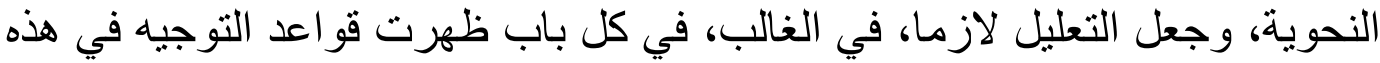

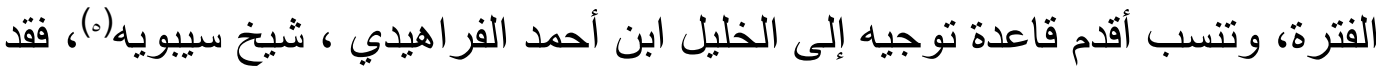

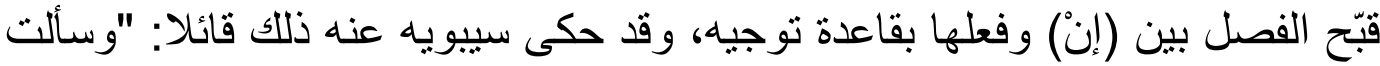

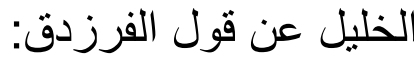

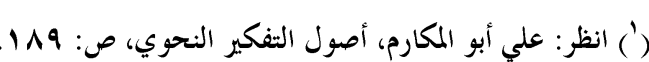

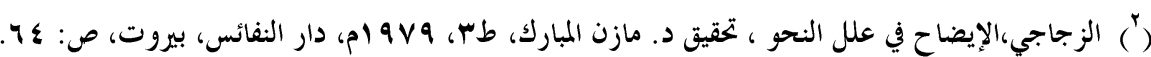

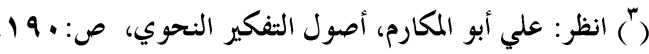

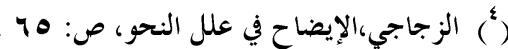

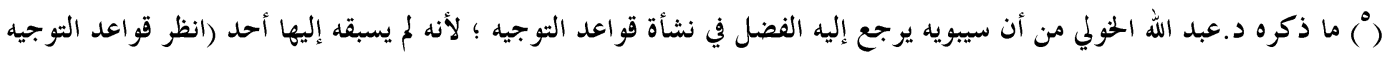
صץ ا) غير صحيح ، فالحليل بن أحد سابق لسيبويه وقد استنبط أول قاعدة تو جيهية. 


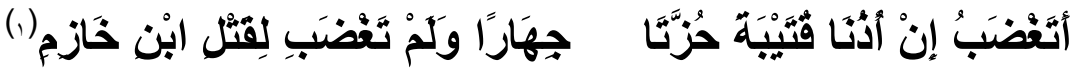

فقال:"لأكَّهُ قبيحُ أن تفصل بين (أنْ) والفعل، كما قبح أن تفصل بين (كي) و الفعل،

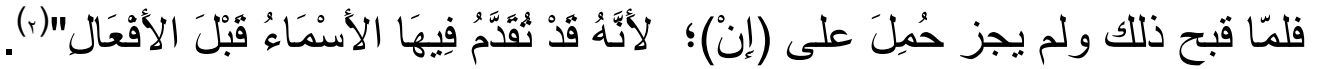
وتلاحظ أن السياق سياق تعليل لكسر همزة (إنْ)، فعلل ذللك الخليل بقاعدة التوجيه:

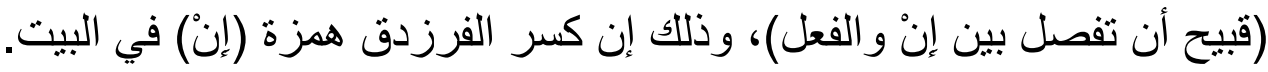

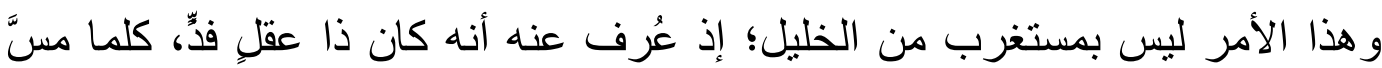

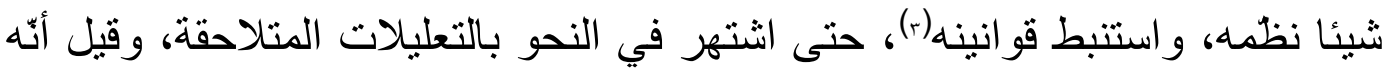

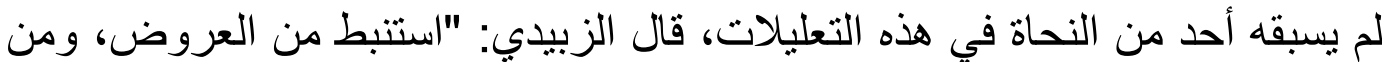

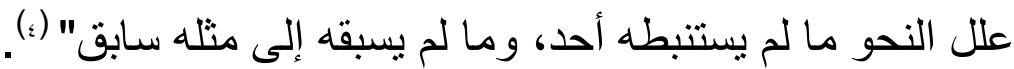

على أنَّ التعليل والعلة التي هي الحكم الرابع في القياس النحوي سادا منذ فترة الخليل

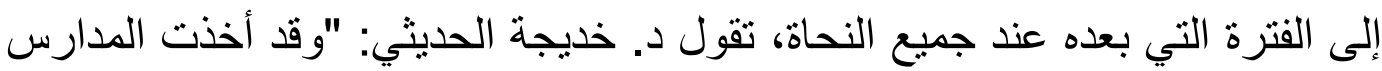

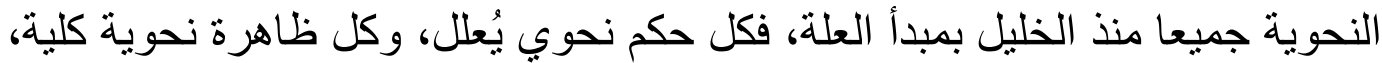
أو جزئية لابد لها من علة عقلية أوجدتها" (ه).

فإذا عرفنا ارتباط هذا النحوي بالتعليل، وارتباط قواعد التوجيه أيضا بالتعليل،

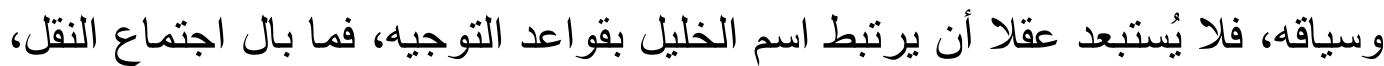

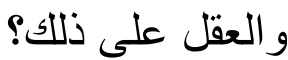

و هذا لا يعني أنَّ الخليل استتبط كل قواعد التوجيه، بل كل قاعدة تختلف في نشأتها

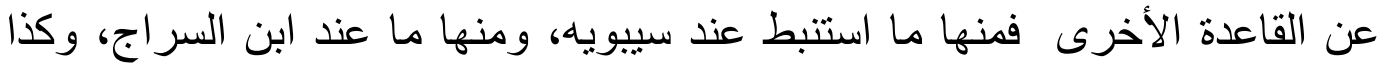

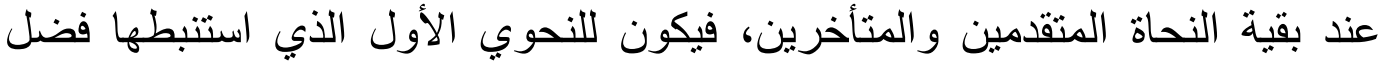

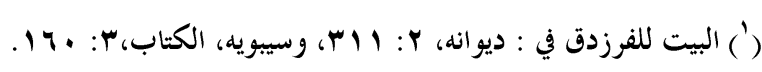

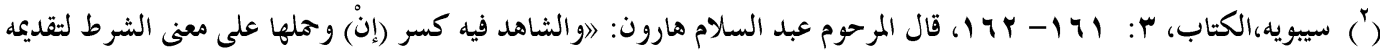

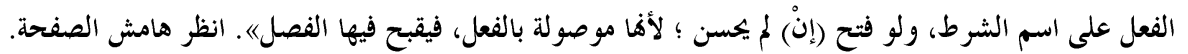

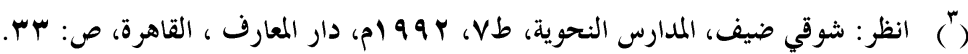

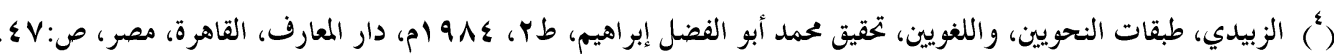

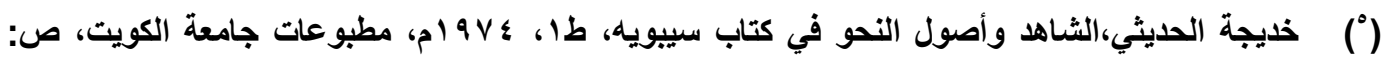


النشأة للقاعدة التي ذكر ها، و السبق في صياغتها، و لا يظهر ذللك إلا في تتبع كل قاعدة عن النحاة كما فعل الدكتور/عبد الله الخولي في أغلب القواعد التي ذكرها في في حديثه

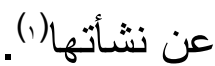

ثانيا: كثرة قواعد التو جيه بكثرة التعليل، وقلتها بقلته:

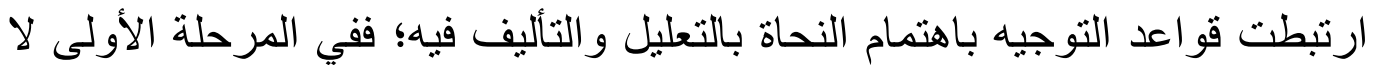

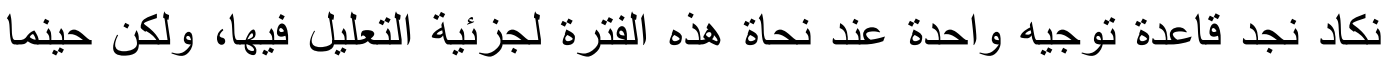

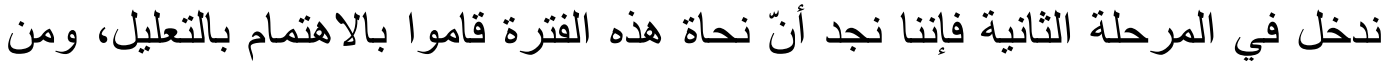

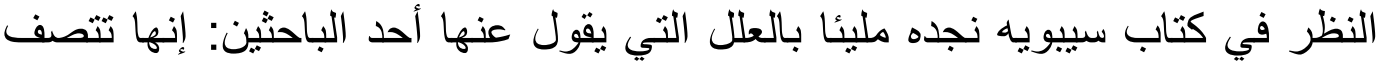

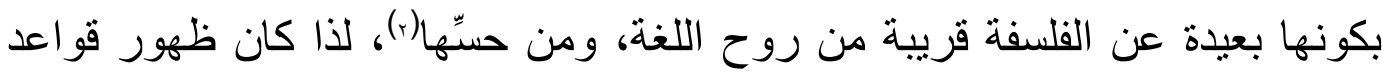

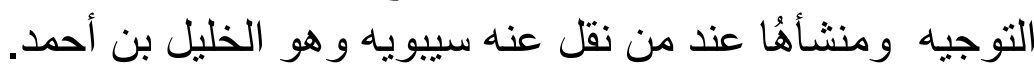

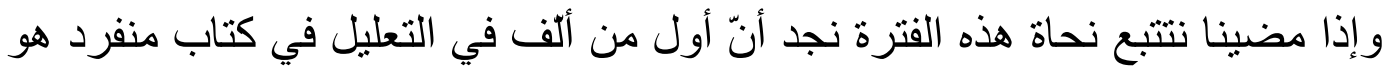

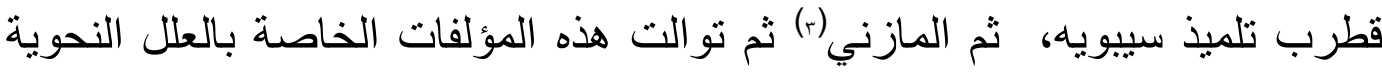

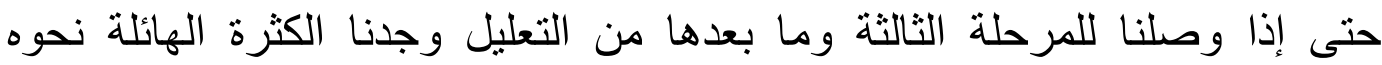

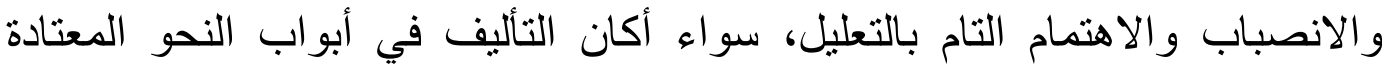

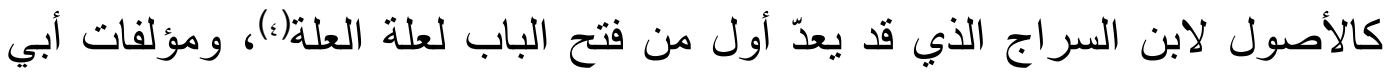

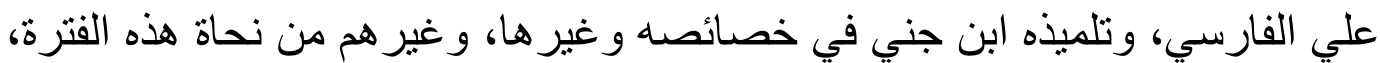

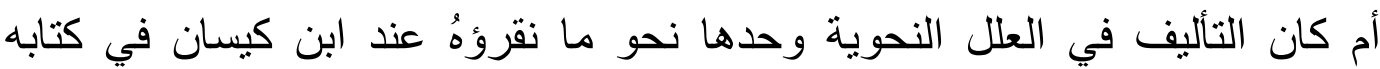

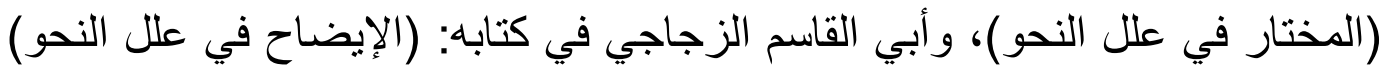

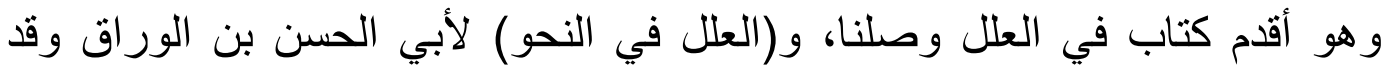

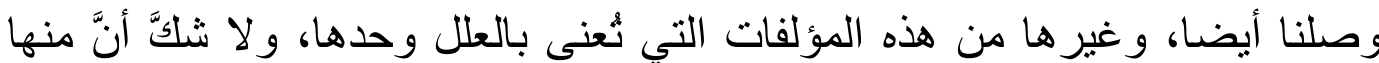

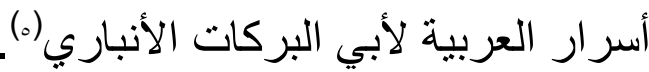

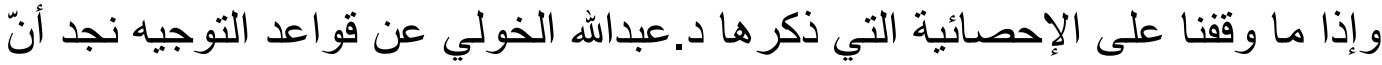

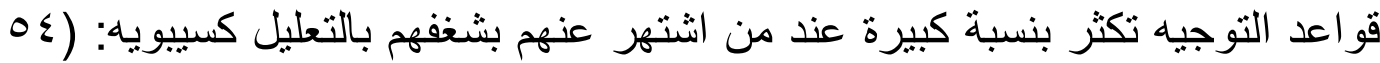

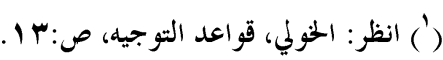

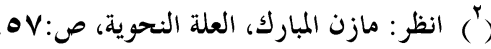

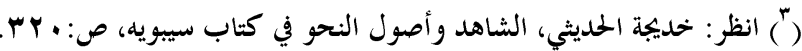

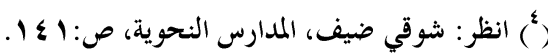

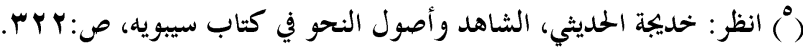




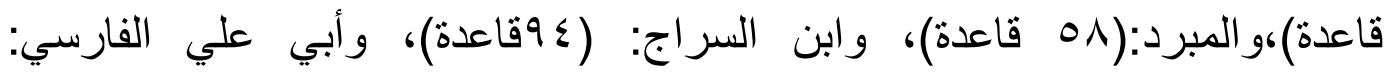

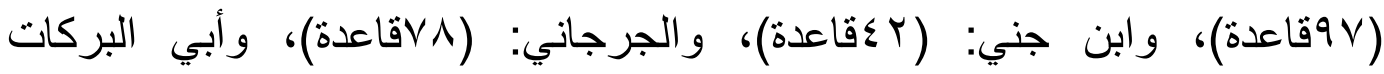
الأنباري: (• جrقاعدة)(1) ، و الباقي نجده واضحة)، واضحا عند نحاة الفترة الثالثة.

و هذا دليل على ارتباط قواعد التوجيه بالعلل النحوية، والتعليل النحوي، وتطوره

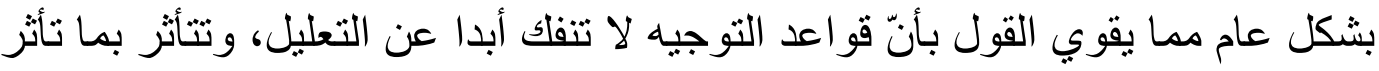

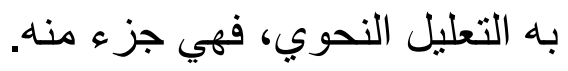

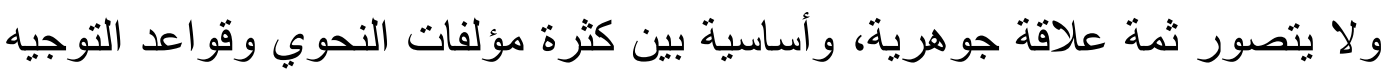

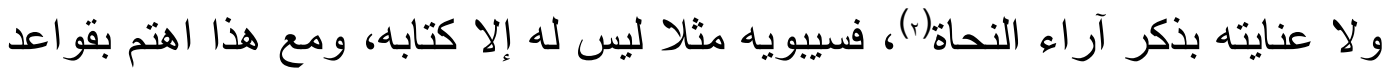

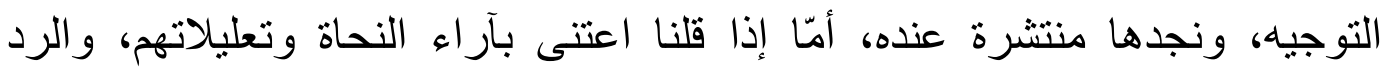

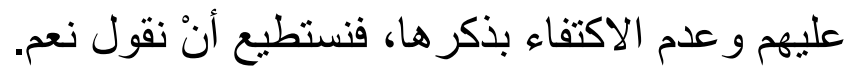

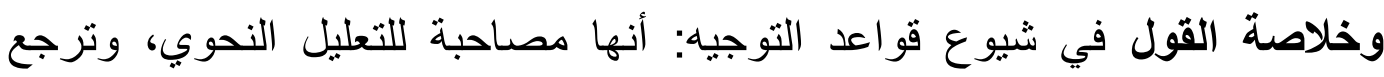
كثرتها عند النحوي لكثرة تعليلاته، و الاهتمام بتعليلات النحاة وتها وتحليلها و واستدلالاتهم.

خامسًا: مصادر قو اعد التوجيه عند النحاة وصياغتها:

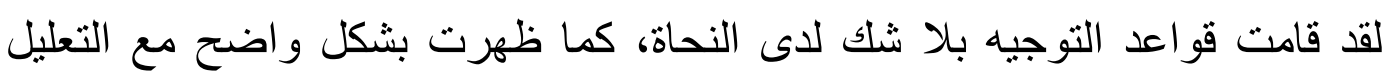

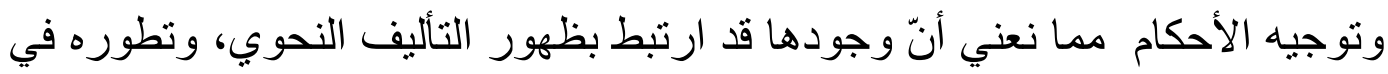

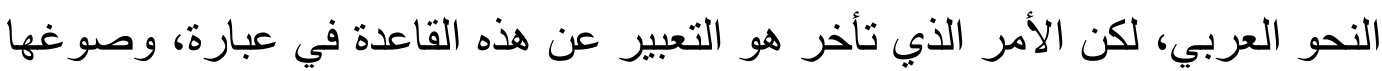
في جملة لكي تستحق أنْ بطلق عليها لقب (قاعدة) عند النحاة. ومصادر هذه القواعد عند النحاة لا تتعدى أنْ تكون إحدى هذين المصدرين:

الأول: أنْ تكون قاعدة التوجيه من صياغة النحوي نفسه: ويعني بذللك أن بعض النحاة عندهم القدرة على استنباط هذه القواعد، و إظهارها، فيكون له فضل السبق إلى ذكر هذه القو اعد في مؤلفاته.

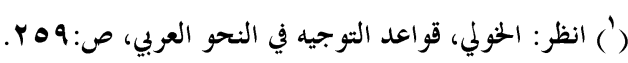

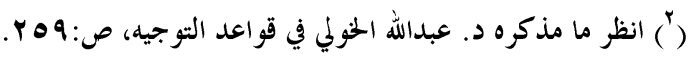


ومن هؤلاء سيبويه، فكتابه يعدُّ أقدم الكتب التي وصلت إلينا في النحو، وقد إند عني في كتابه

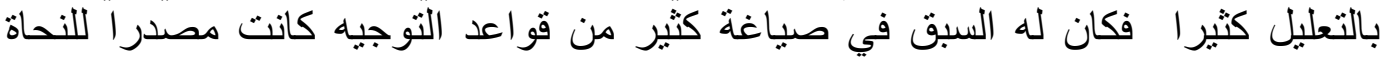

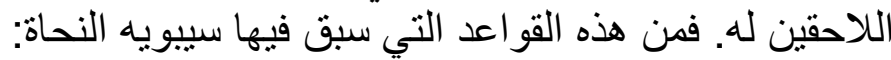

ا - ما ضارع الفعل المضارع من الأسماء في الكلام ووافقه في البناء أجرى لفظه

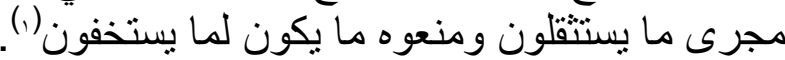

$$
\text { r- لا يعمل في اسم واحد نصب ورفع(r). }
$$

r- الحروف بمنزلة الفعل فلما حذف من نفسه شيء لم يغير عمله(r).

ــ الحد أن يكون الفعل مبتدأ إذا عمل(ء).

0ـ لا يجوز للك أنْ تجعل الاسم، و الصفة بمنزلة اسم واحد، وقد فصلت بينهماء).

7ـ المضاف، و المضاف إلبه بمنزلة اسم و احد منفرد(؟).

ومنهم أيضا الفر اء الذي صاغ قاعدة: (الخافض وما خفض بمنزلة الحرف الو احد)(v).

كذا المبرد الذي سبق النحاة بقاعدة: (إذا جاز الجمع بين شيئين فليس أحدهما عوضا من

الآخر)(^)، وقاعدة: (لا يقع فعل على فعل) (و).

و ابن السراج في قاعدة: (لا يجوز أن تقدم الصفة على الموصوف، ولا أن تعمل الصفة فيما

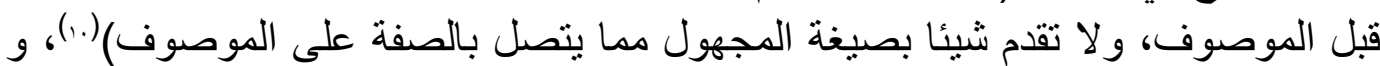

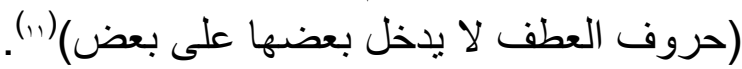

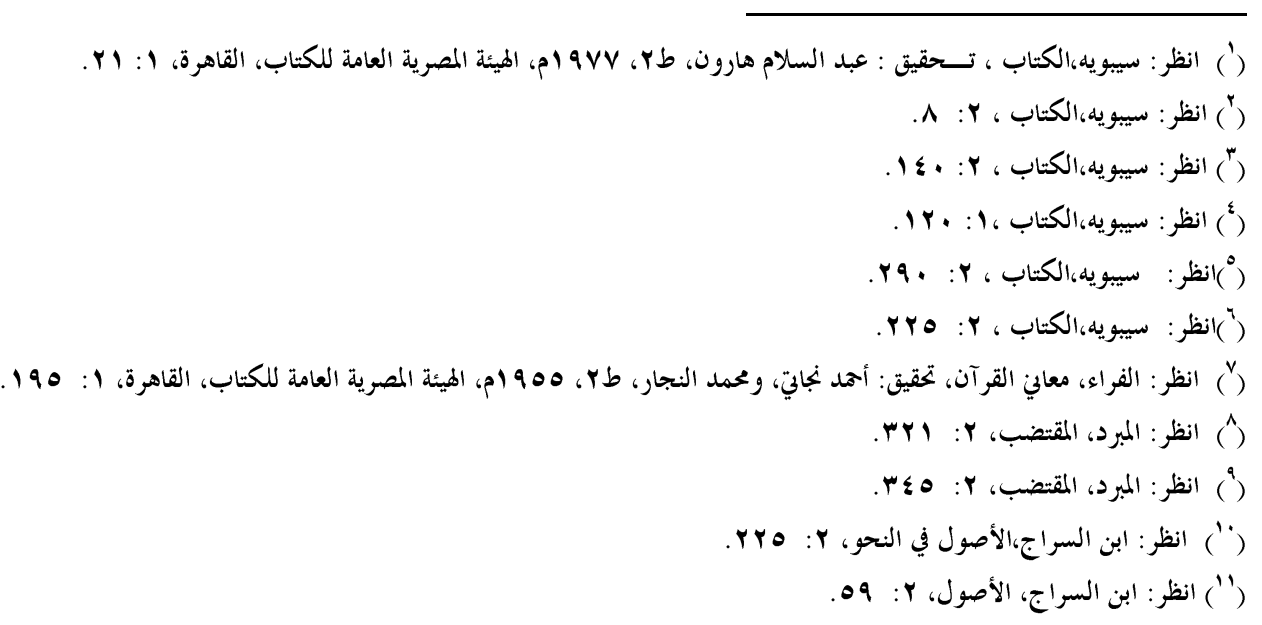


ونسبة أولية هذه القواعد كلها للنحاة تحتاج لجه كبير لكثرة هذه القو اعد وتنوعها وكثرة المؤلفات النحوية، فقد تكلف الباحث جهاه ووقتا كتاه كبير التتبع كل قاعدة عند كل

نحوي.

\section{الثاني: أن يستفيل النحوي مِمَّنْ سبقِه في وضع قاعدة التوجيه:}

هذا هو الغالب عند النحاة المتأخرين، فأغلب ما ذكر من قواعد كان للنحاة السابقين الفضل في صياغتها والسبق في ذكرها، وما كان من النحوي اللاحق إلا نقلها كمان

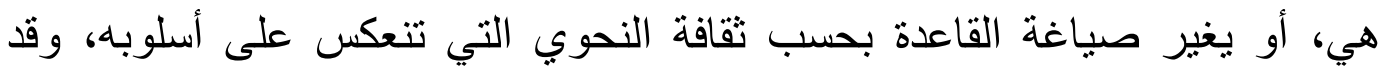

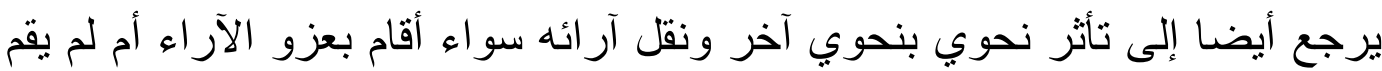

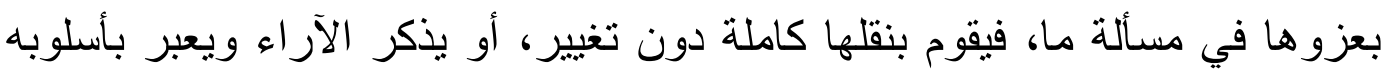

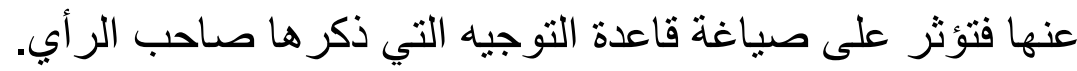
وسوف نمثل على بعض ما سبق ذكره من القواعد:

قاعدة سيبويه: (ما ضارع الفعل المضارع من الأسماء في الكلام وو افقه في البناء

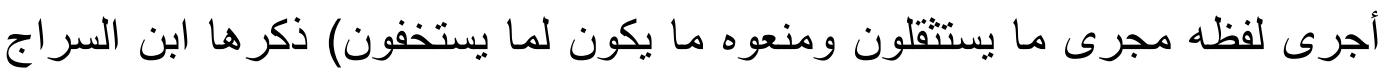

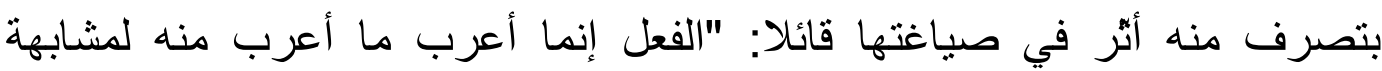

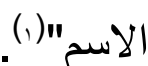

لقد جعل ابن السراج كتاب سيبويه مصدرا لهذه القاعدة، ولكيّه عبّر عنها بأسلوبه فغير من صياغتها التي كانت عليه عند سيبويه. ومثلها قاعدة سيبويه: (لا يعمل في اسم واحد نصب ورفع)، فقد قام ابن السراج بصياغتها صياغة أخرى قائلا: "لا يجوز فئل أنْ يعمل في شيء عاملان" (r). كذللك قاعدة سيبويه: (الحد أن يكون الفعل مبتدأ إذا عمل)، قال ابن السراج: "مرتبة

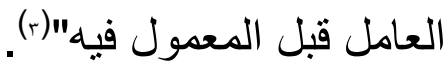


ولا يعني ذلك أنَّ النحوي اللاحق ينقل عن النحوي الذي سبق بهذه القاعدة نقلا

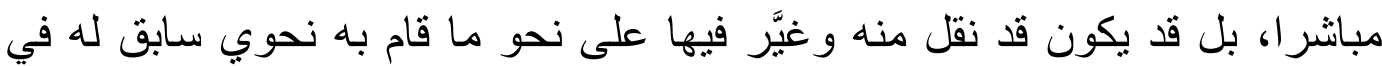

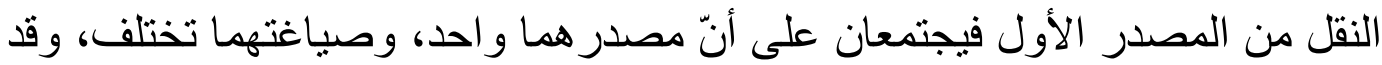
يكون نقلهُ من الأول نقلا غير مبانشر بحيث ينقل عن الناقل الأول، وهو إمَّا يحافظ

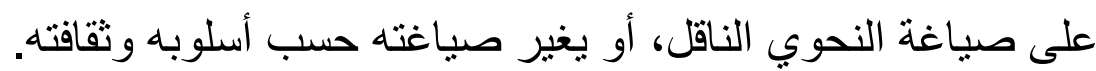

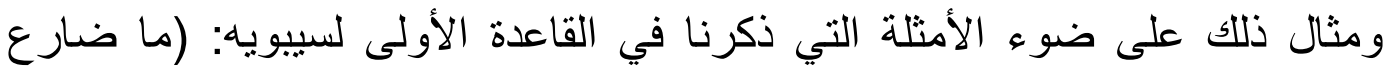

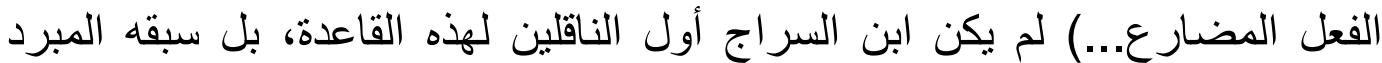

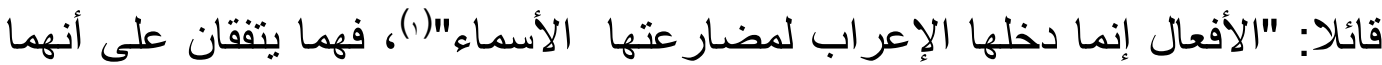

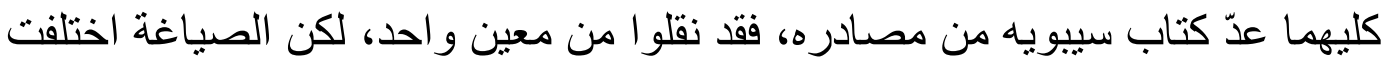
عند كل و احد منهما.

وقاعدة: (لا يعمل في اسم واحد نصب ورفع) صاغها ابن السراج على ما قرأناه،

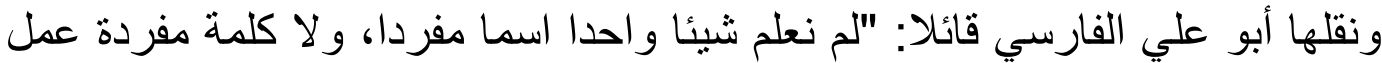

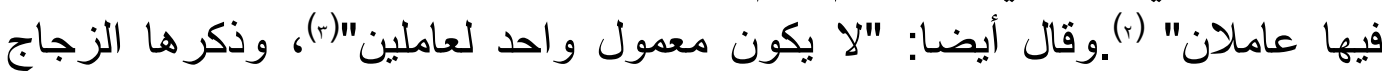

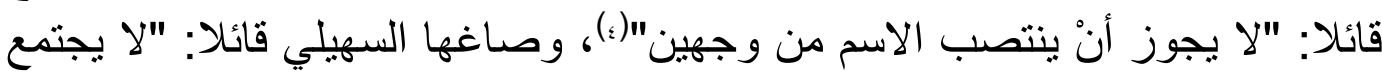

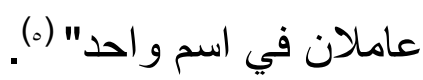
وما مثلنا به قليل قد بغني عن الكثير؛ لأن الغالب عند النحاة هو هذا النوع، فمتى ما

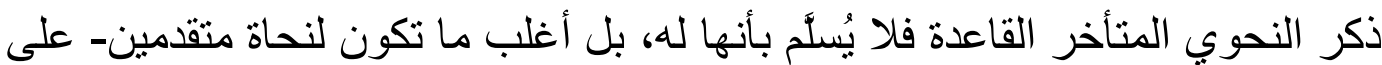

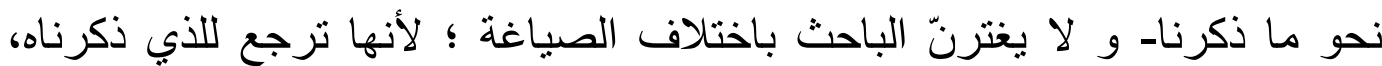
ونظنه هو السبب(ت) كان.

سادسًا:الأسباب التي أدّت إلى اختلاف قو اعد التو جيه بين النحاة:

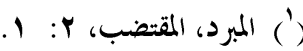

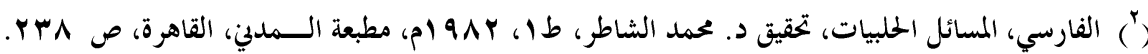

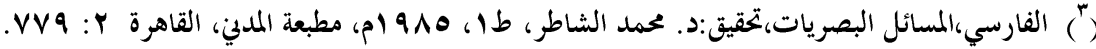

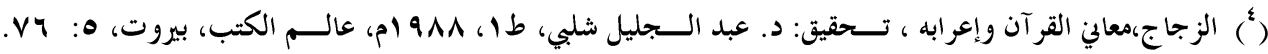

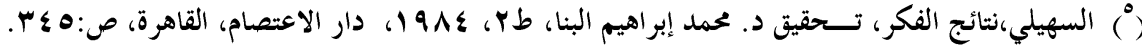

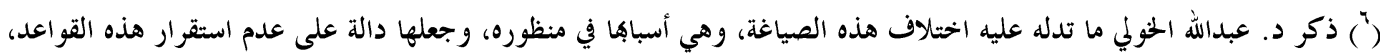

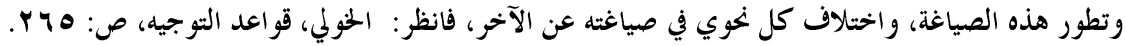


لقد تَنَوَعَتَّ قو اعد التوجيه في مؤلفات الأنباري كما ر أينا فيما سبق من المباحث، و هذا

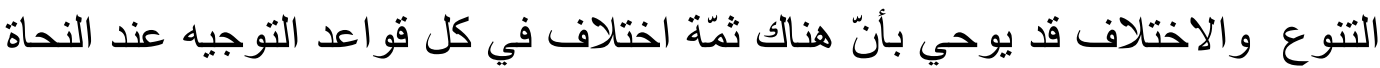

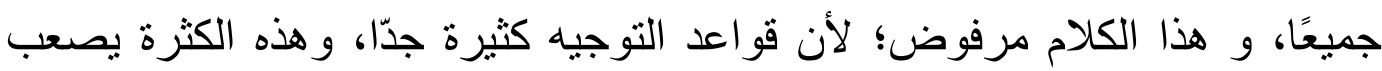

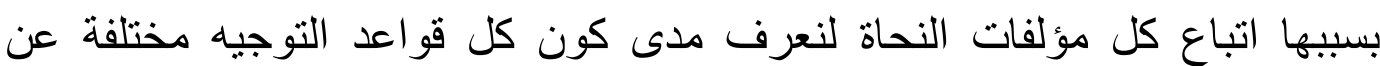

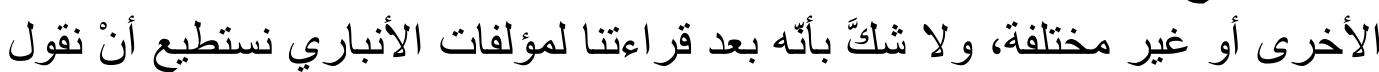

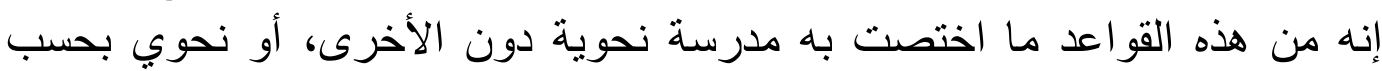

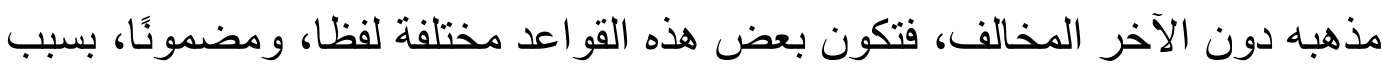

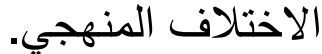

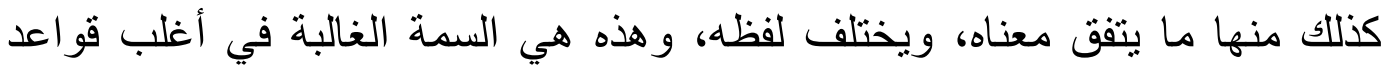
التوجيه، فيكون هناك اتفاق على هذه القاعدة، وعمل هذه القاعدة، والاستفادة منها إلا فيأ

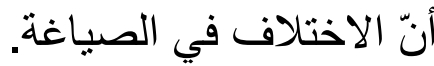

ولعلنا نستطيع حصر الأسباب التي أدّت إلى ظهور قواعد التوجيه بهذه الصورة صورة الاختلاف- بين النحاة بما يلي:

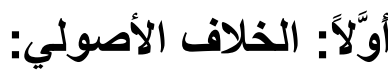

إنَّ لاختلاف الأصول النحوية التي يبني عليها النحاة أحكامهم أثرًا كبيرًا في فكر الأنا

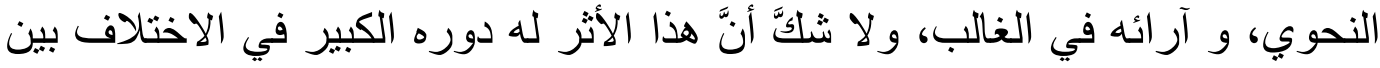
النحاة في قواعد التوجيه نفسها؛ لأنها وليدة فكر النحاة، وما تحكمهم بها من أصولي الصالِ نحوية أقامو ا بها تللك الأفكار ، والآر اء، والتعليلات.

ولقد برز ذلك في مؤلفات الأنباري، وخصوصا حينما يعرض المسائل الخلافية بين المدرستين البصرية والكوفية، أو بين نحوي من ونحاة أحد المدرستين مع الآخر. فأولى هذه الأصول التي أدّت إلى هذا الاختلاف:

(1) السماع (المقيس عليه) والقياس عليه: لقد كان البصريون لا يقيسون على القليل والنادر والثـاذ و الضرورة، وذلك ؛ لأنهم يختلفون عن الكوفيين اليهرين 
في شروطهم المكانية، والزمانية في المسموع() بخلاف الكوفيين، فالبصريون

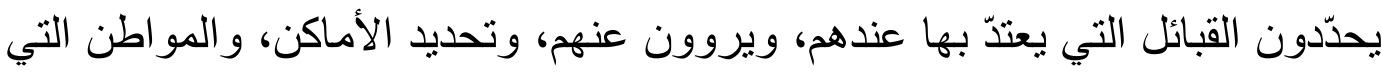

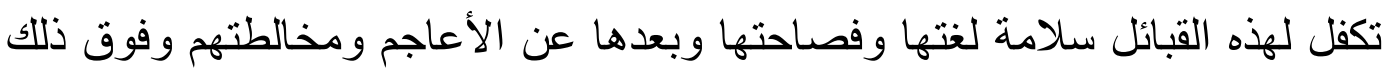

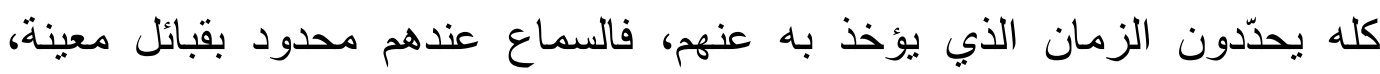
محدودة بمكان، وزمان لزمان معيّن.

أمّا الكوفيون فيأخذون من قبائل العرب جميعا دون تحديد، وعن كل الرواة، فكل

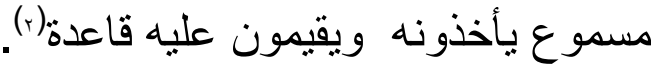

ولا شكَّ بأنَّ أثز ذلك كبير في القياس بينهم، فالبصريون هم الأصح قياسا يقول

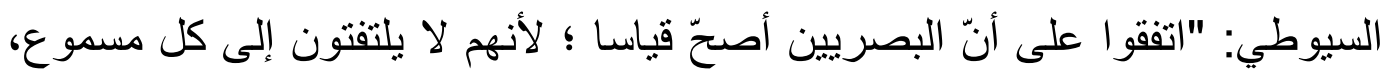
و لا يقيسون على الثناذ"(r).

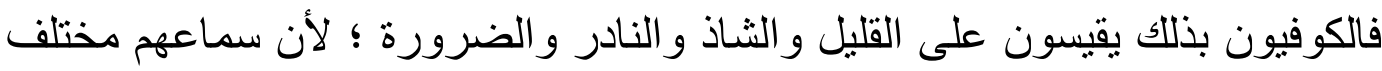

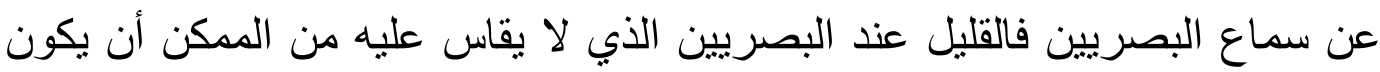

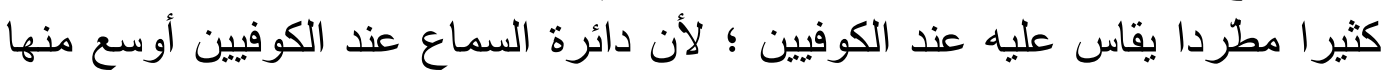

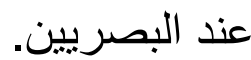

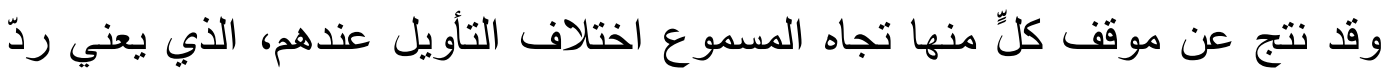

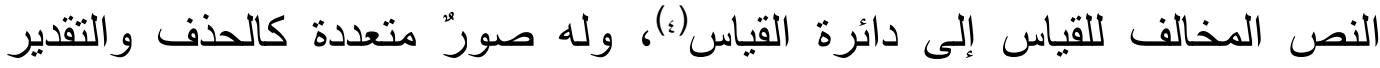

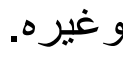

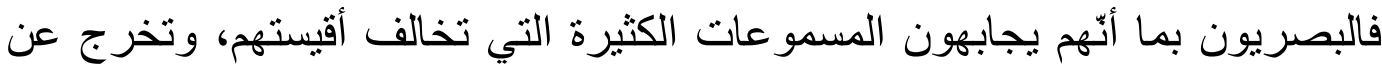

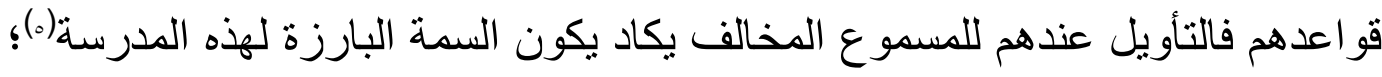

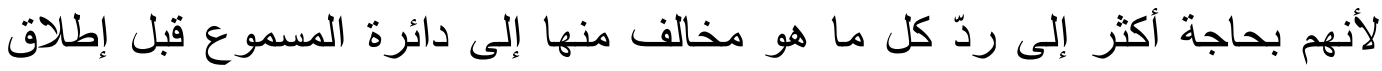

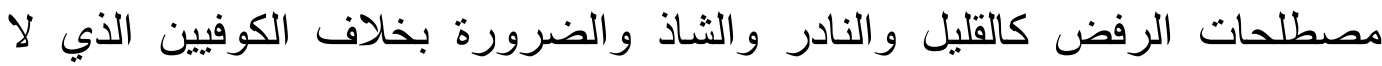

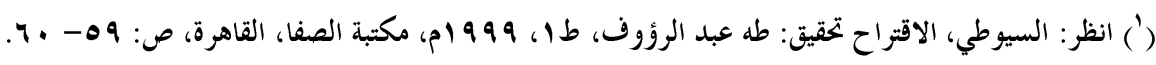

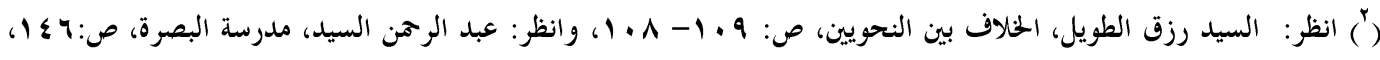


يعتمدون عليه كاعتماد البصريين عليه، يقول د. السيّد الطويل: "و التأويل و التقدير في

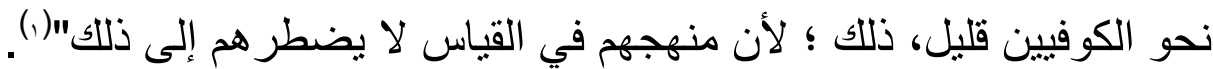

كل ذلك تسبب بظهور قواعد خاصة بمدرسة دون الأخرى بمعنى أنّ هناك قواعد

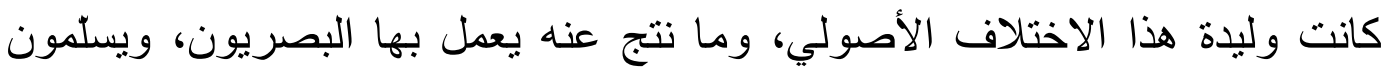
بها، و لا يعمل بها الكوفيون، و لا يسلمون بها و العكس صحيح.

فمن هذه القواعد التي تخص مدرسة دون الأخرى بسبب الاختلاف الأصولي في

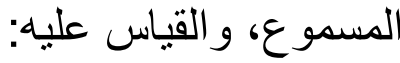

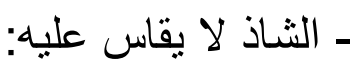

وقد استدلّ بها البصريون دون الكوفيين ليردوا بها مسموعا، وهذا المسموع من فن الكون

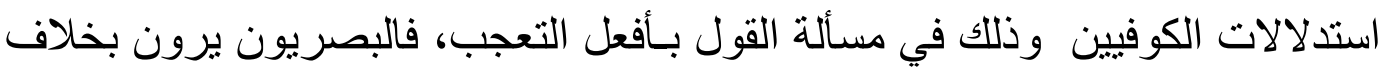
الكوفيين فعليتها، وما استدلّ به الكوفيون من قول الثاعر:

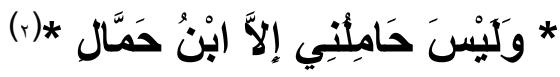

حملوه على الثذوذ الذي لا يجوز القياس عليه(r)، فهم يعملون بمعنى هذه القاعدة. كذلك عدم جواز القياس على الضرورة فكثبرا ما كان بيتعطها الأنباري في ردوده

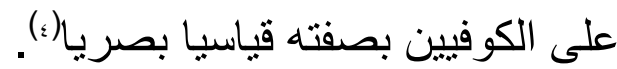

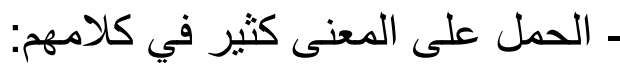

وهي قاعدة مرتبطة بالتأويل للنص المسموع، وقد استدلّ بها البصريون على إثبات حكم عدم الصرف في (عامر) من قول باعل الثناعر:

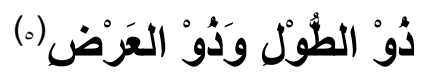

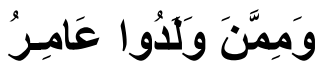

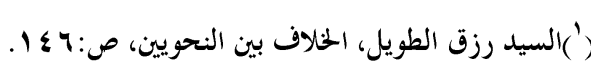

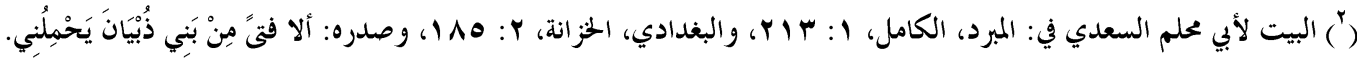

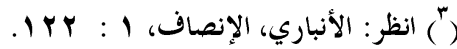

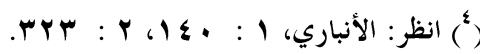

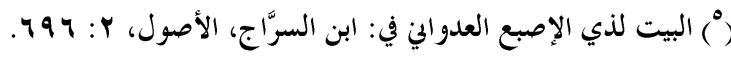


مع تقوية القاعدة بالسماع(1). ـ الحمل على الجوار من الثشاذ الذي لا يعرج عليه: وقد ردَّ بها الأنباري شواهد الكوفيين، وقياسهح عليها ؛ لأنها من الثاذ الذي لا يقاس عليه، وذللك ودنا

في مسألة: ( عامل الجزم في جواب الثرط )، وجزمه على الجوار عندهم(r). ـ الحذف على سبيل الوجوب و الجواز لدلالة الحال كثير في كلامهم:

و هذا من كلام الأنباري يردُّ به على أهل الكوفة مؤيدا بذلك البصريين، فقد ردّ بها على تعليلات الكوفيين من استقر ائهم للمسموع عندهم في تأيبد اسمية (ربّ) و أنيّه لو لو

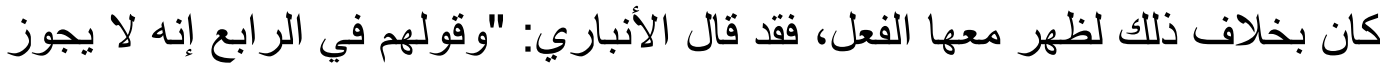

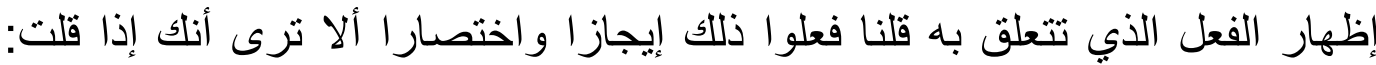
رب رجل يعلم كان التقدير فيه رب رجل يعلم أدركت أو لقيت فحذف لدلالة الحال الحال عليه ...... و الحذف على سبيل الوجوب و الجواز لدلالة الحال كثير في كلامهم"(r).

(r) الدقة في ملاحظة المادة المسموعة، وضبط القياس عليها:

من أهم الأمور في القياس الصحيح استقر اء المادة المسموعة، وملاحظتها ثم ضبط

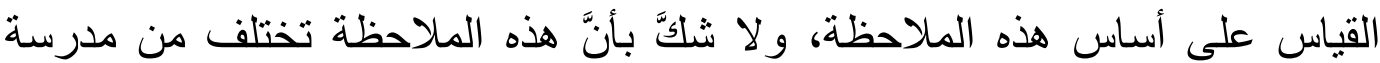

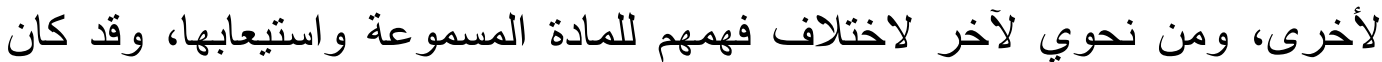

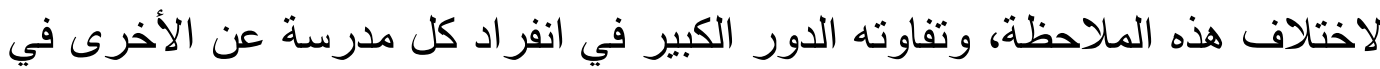
قو اعد التوجيه، فمن هذه القو اعد:

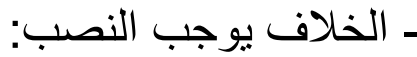

$$
\begin{aligned}
& \text { (') انظر: الأنباري، الإغراب في جدل الإعراب، ص:9 ؟- . .ـ. }
\end{aligned}
$$

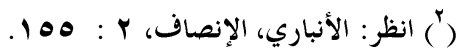

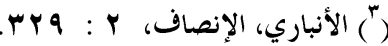


انفرد في هذه القاعدة الكوفيون، وقد استدلو ا بها في عدة مواضع، وذلك في إثبات حكم نصب الفعل المضار ع بعد الواو المعية بالمخالفة مع شرح لهذه لهذه القاعدة. (1). كذلك استدلوا بها، و عملو ا بمعناها في إثبات حكم نصب المضار ع بعد فاء السببية(r)، ونصب الظرف الو اقع خبرا، فهي العاملة عندهم(r)، كذللك إثبات حكم نصب إنب المفعول

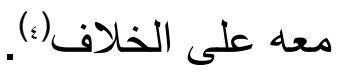

ومصطلح الخلاف عندهم ناتج على ملاحظتهم للمادة المسموعة، و واستيعابها، بالاختلاف في المعنى بين المفعول معله، وما قبله يوجب النصاج ملاحف، فهو عامل معنوي، و هذا ينبع من فهمهم للمسموع.

أما البصريون فلا يرون بمسألة الخلاف أصلا، ولا يعتبرونه عاملا. - ليس في كلام العرب عامل يعمل في الاسم النصب إلّا ويعمل الرفع: استدلّ بها البصريون وحدها على نفي حكم جعل (إنّ) تعمل في الاسم النصب، ورلا

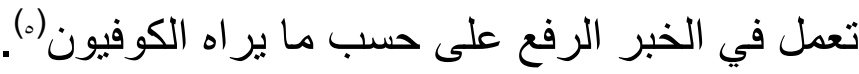
و هذه القاعدة دليل على استقر اء البصريين لمادتهم المسموعة التي أتيحت لهم؛ لأنه بها عرفوا أنّ كل عامل ينصب يجب أن أنْ يرفع.

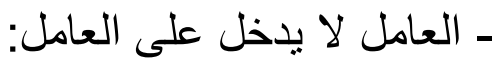

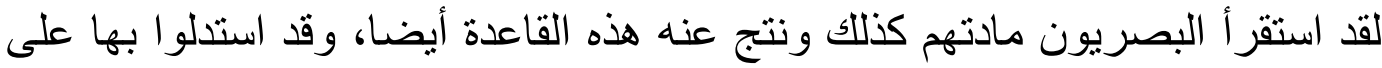

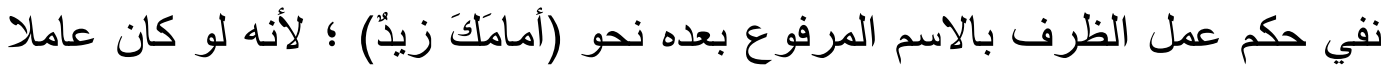

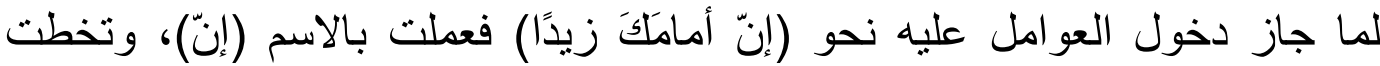

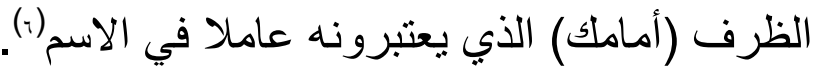

$$
\begin{aligned}
& \text { (') انظر: الأنباري، الإنصاف، Y: V. P. }
\end{aligned}
$$

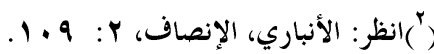

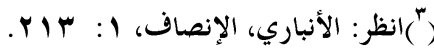

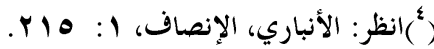

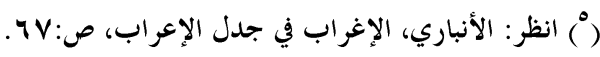

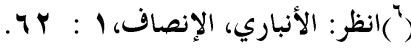


و الكوفيون لا يرون بذللك، فعندهم جواز دخول العامل على العامل و الدليل على ذلك

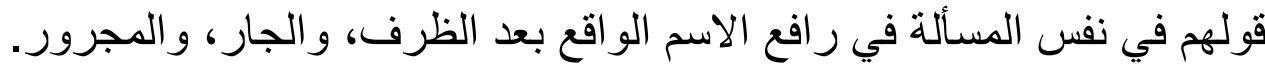
كذللك ذهاب إمامهم الكسائي في أنّ الفعل المضارع يرتفع بالزوائد التي قبله (أنيت) - عامل الجر لا يعمل مع الحذف:

وجد البصريون أنَّ عامل الجر لا يحذف ويبقى عمله في الاسم المجرور، وذلك بما

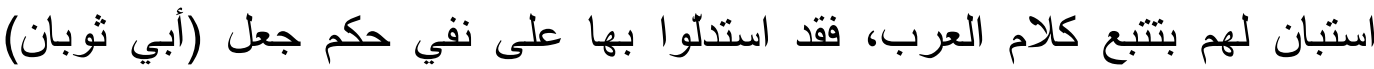
مجرورة بحرف جر محذوف، في قول الثناعر:

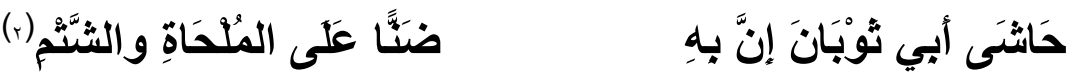

أمَّا الكوفيون فهم يرون خلاف هذه القاعدة تماما، فيقولون: إعمال حروف الخفض مع

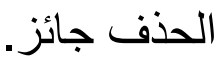

وذللك حينما استدلّو ا بها و عملو ا بمعناها مع تقويتها بالسماع في أنّ حرف القسم يعمل مع الحذف(r). ثانيًا: الخلاف الفكري: - ان

عرف عن البصريين تحكيمه المنطق، والعقل في أقيستهم "واستخدام الأحكام

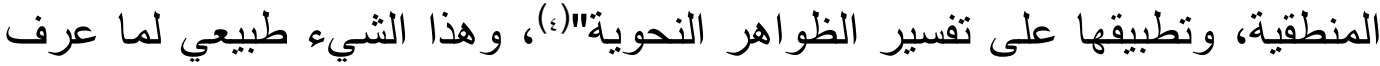

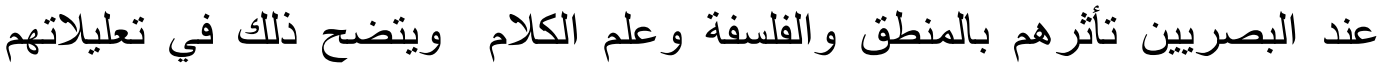

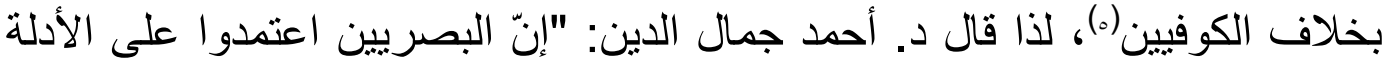

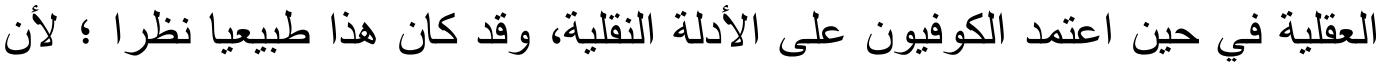

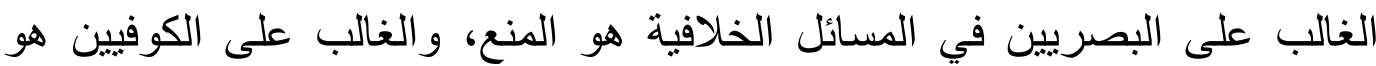

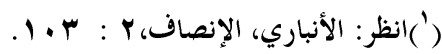

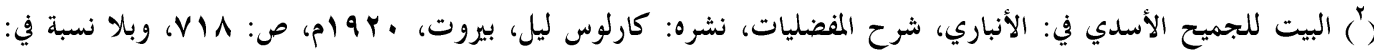

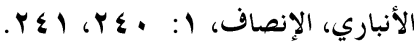

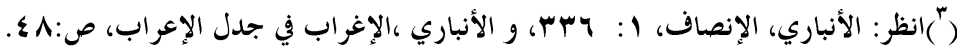

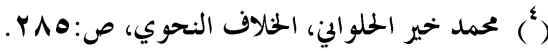

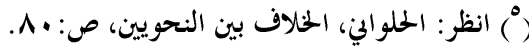


الإجازة، والإجازة تحتاج إلى أدلة نقلية يقيم المحتج على أساسها مذهبها، والمنع إلى الدهاة

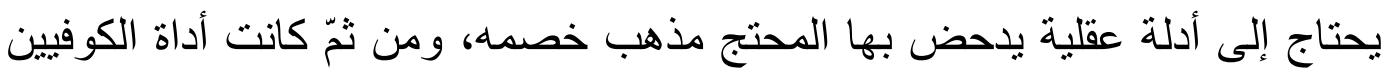
الأساسية هي النقل، في حين كانت أداة البصريين الأساسية هي العقل" (ل). وهذا الأثر لله أثاره الجلية على النحو عامة والخلاف والاستدلال على وجها

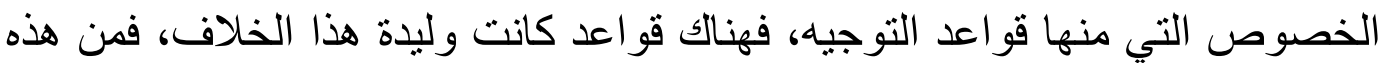
القواعد التي أبرزها الخلاف الفكري:

- إضافة ما لا تأثثر له في العمل إلى ما له تأثثر ينبغي أنْ يكون لا تأثثر لله. ويتضح من صياغتها المصطلح المنطقي ( التأثر )، وقد استدلو ا بها على الحكم بأن

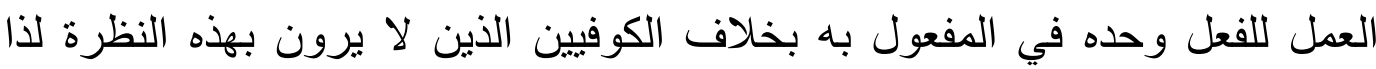

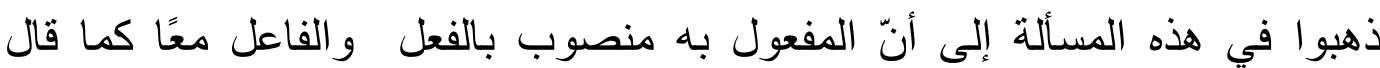

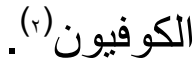

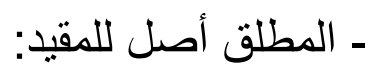

وقد قالها البصريون مستدلين استدلّ بها على إثبات حكم أنّ المصدر أصلُ الفعل، الفّل

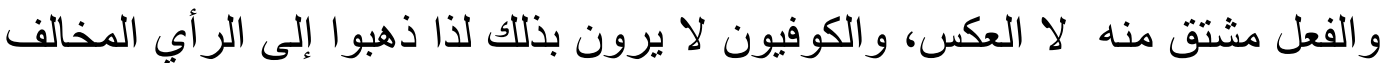
لذلك (r) ـ المعمول لا يقع إلا حيث يقع العامل: و هذه من ناحية رتبة العامل، و المعمول،ققد استدلّ بها البصريون لجواز القول بتقديم

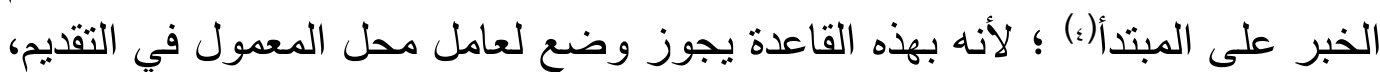

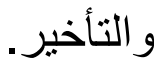

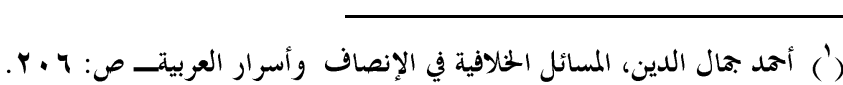

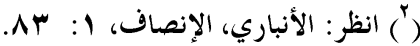

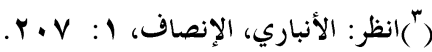

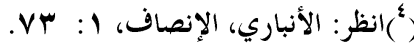


- ما يستغني بنفسه، ولا يفتقر إلى غيره أولى بأن يكون أصلا مما لا يقوم بنفسه،

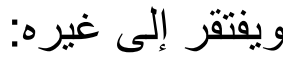

وهي فكرة الجوهر ، و العرض، و الفرق بينهما()، وقد استدلّ بها البصريون مع قاعدة توجيهية أخرى على حكم عدم جواز تقديم خبر (ماز ال ) عليها(ب).

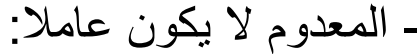

و هذه كانت من استدلالات الأنباري، وهو و إن كان بصريا في الغالب إلا أنّه نأنزر بما

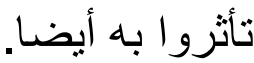

وقد استدلَّ بها على نفي حكم جعل الظرف الو اقع خبر ا منصوبا بفعل غير مقدَّر(r). ثالثا: اختلاف صياغة القاعدة :

من الأمور التي قد تشعر بوجود اختلاف في قو اعد التوجيه في كتب الأنباري هي صباغة القاعدة فالقاعدة من الممكن أن تصاغ بصياغة واحدة في كتب الأنباري،

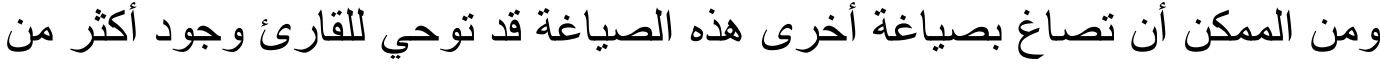
قاعدة توجيه عند النحاة، فمن ذلك: أنكاع:

ذكر الأنباري على لسان البصريين قولهم: (المشبه بالثيء يكون أضعف منه في ذلك الته

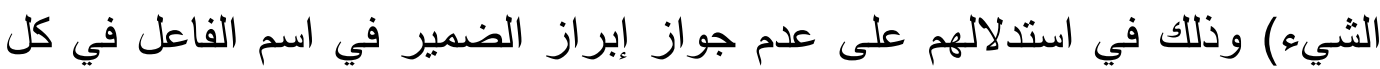
حال()، ثم ذكروا قاعدة (الفروع تتحط عن درجة الأصول) على نفس الاستدلال(م) فئ. و المتأمل في هاتين القاعدتين يجد أنهما بمعنى واحد، وفي استدلال واحد، فالمشبه بالثيء هنا اسم الفاعل و المشبه الفعل، كذلك الفرع اسم الفاعل، والأصل هو الفعل. فمعنى القاعدتين و احد إلا أنّ الصياغة هي تشعر بوجود ثمة خلاف بين القاعدتين مع

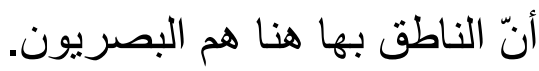

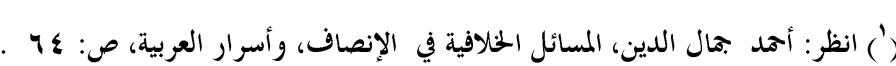

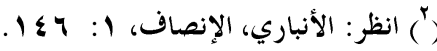

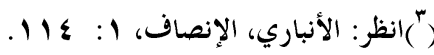

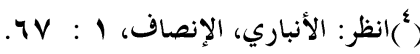

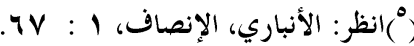




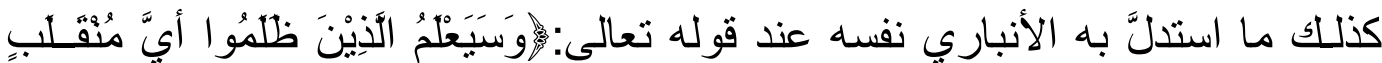

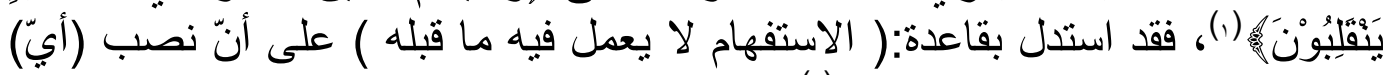
بالفعل (ينقلبون) لا بالفعل (سيعلم) (r).

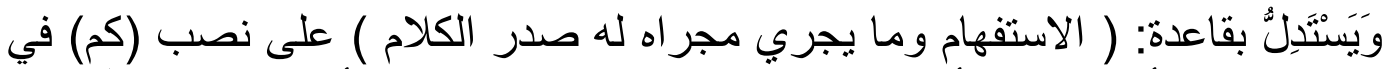

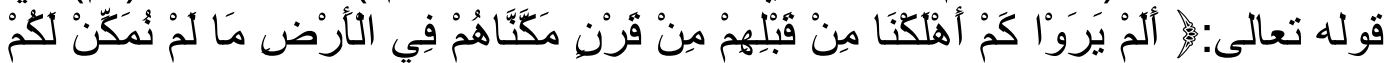

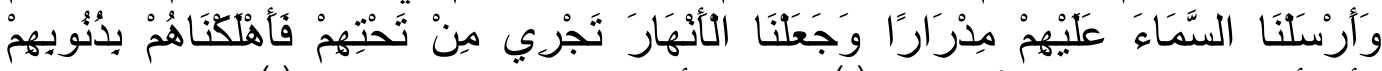

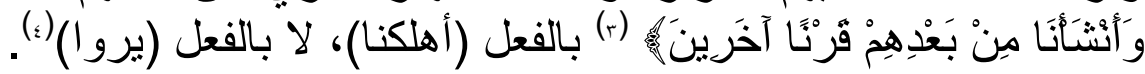

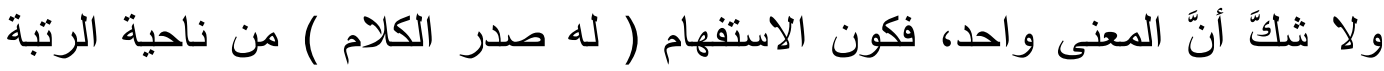

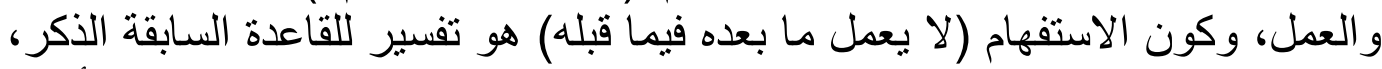

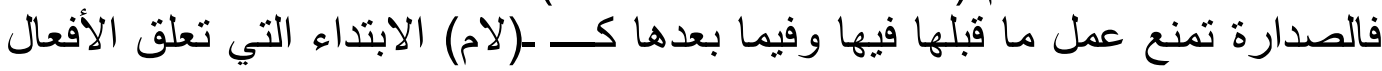
المتعدية لمفعولين و النفي و غير هال فيا.

فالملاحظ هنا تثابه الاستدلالين السابقين، ووظيفة كل قاعدة، إلا أنّ الصياغة اختلفت.

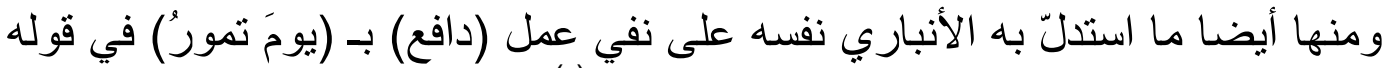

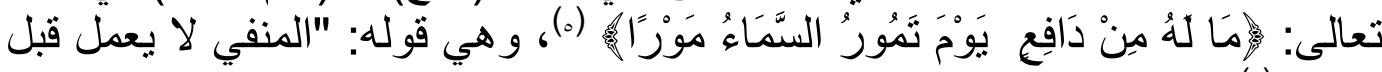

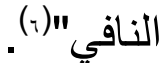

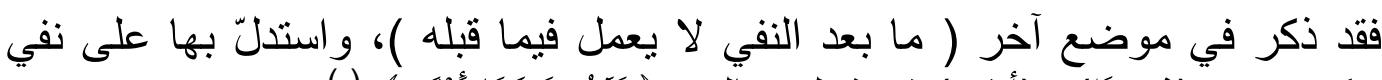

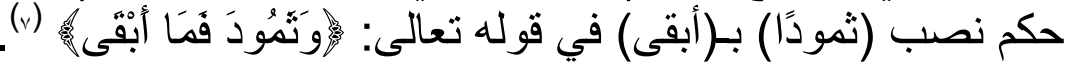

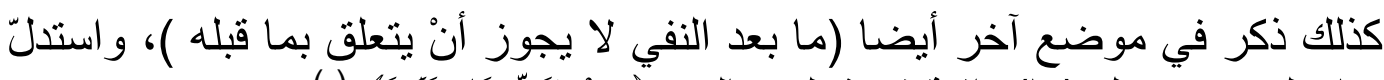

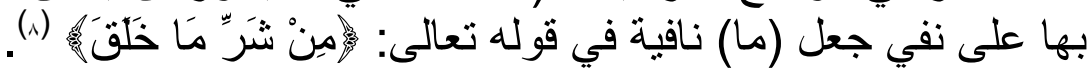

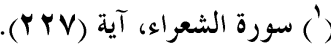

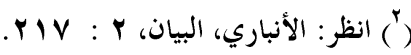

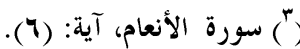

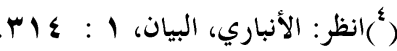

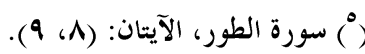

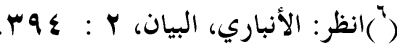

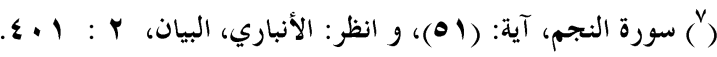

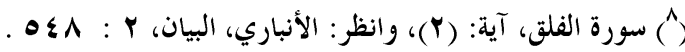




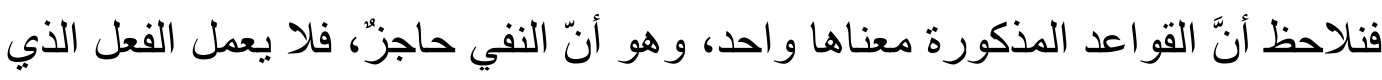

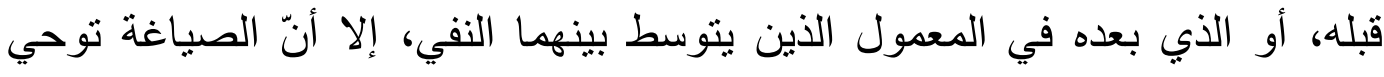
بتعدد واختلاف القاعدة.

و لا شكَّ بأنّ هذا السبب قد يوقع اللبس بوجود اختلاف في قو اعد التوجيه حتى في

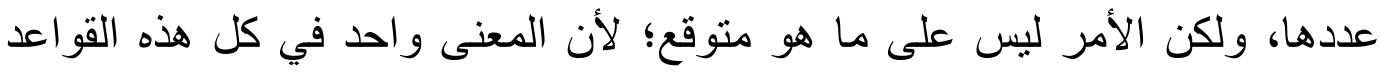
المذكورة سابقا التي ذكرناها في هذا السبب مانب. 
المبحث الثاني: أثر قو اعد التوجيه عند الأصوليين من النحاة في النحو

ابن الحاجب أنموذجًا

$$
\text { العربي }
$$

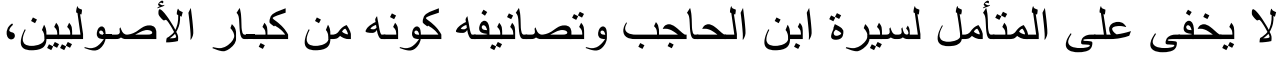

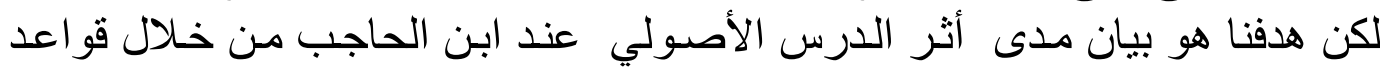

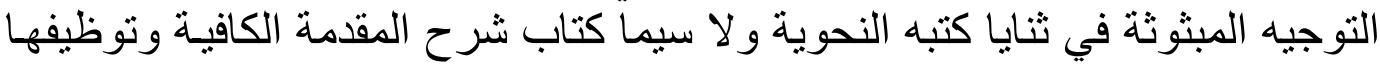

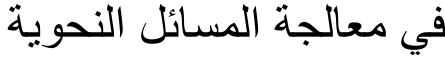
فالناظر في شرح الكافية لابن الحاجب يلمس دون دون جهد أو أو عنداء أن النحو فيها

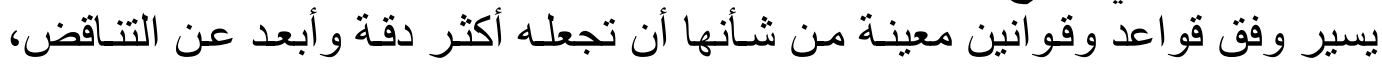

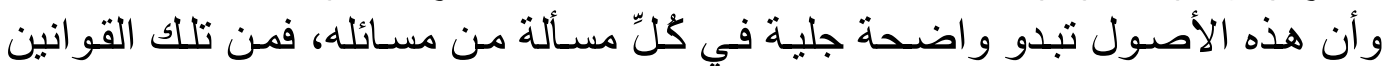

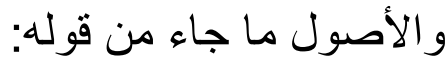

\section{ا - الكلمة والكلام حقيقتان هنتلفتان: هندان:}

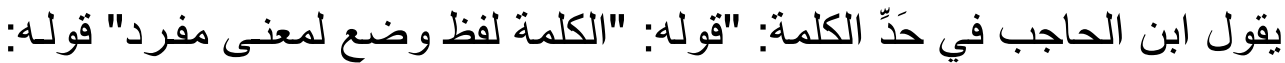

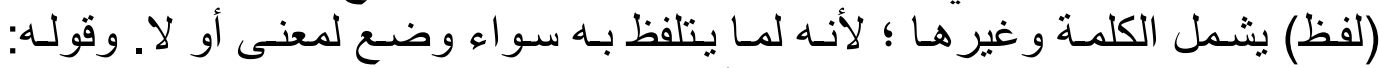

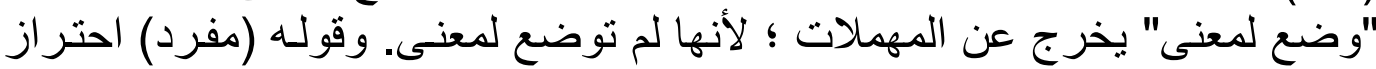

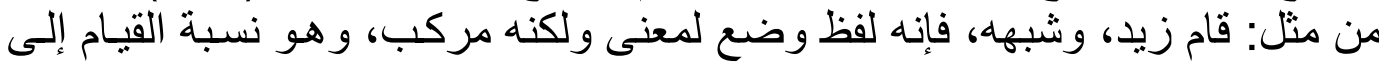

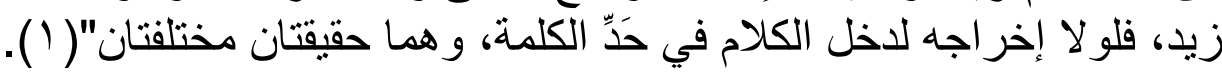

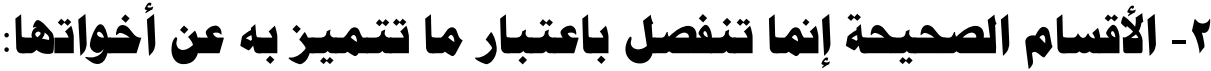

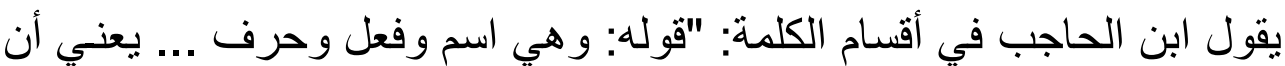

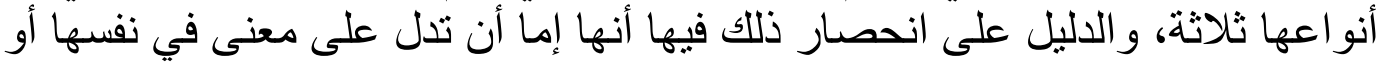

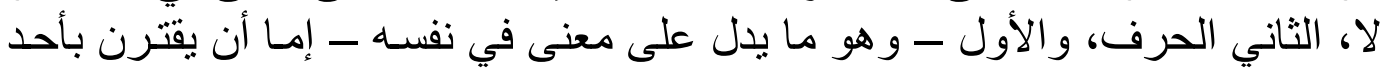

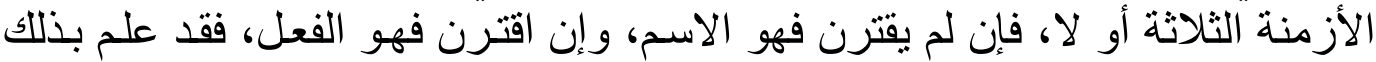

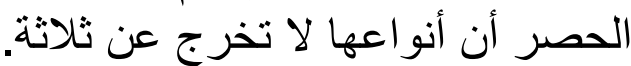
قوله: "وقد علم بذلك حد كل واحد منها"؛ لأن ألنأن الأقسام الصحيحة إنما تنفصل باعتبار

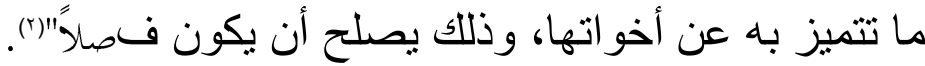

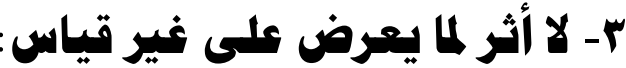

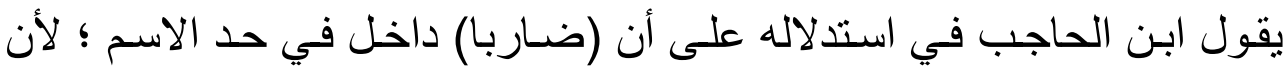

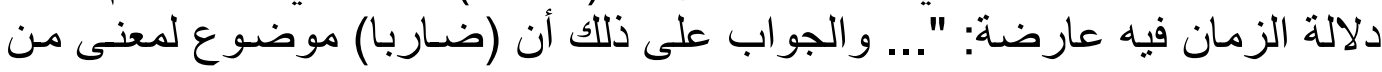
(1) ابن الحاجب،شرح المقدمة الكافية في علم الإعراب،تحقيق:مال عبد العاطي مخيمر أحد، مكتبة نزار مصطفى الباز،مكة المكرمة- الرياض،ط: 1، 


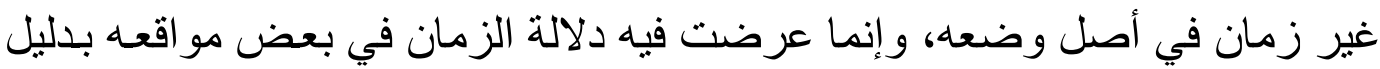

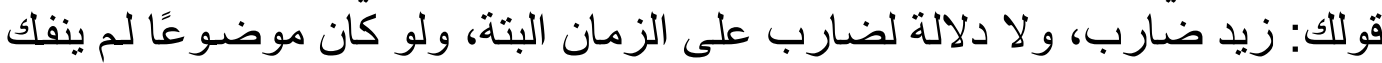

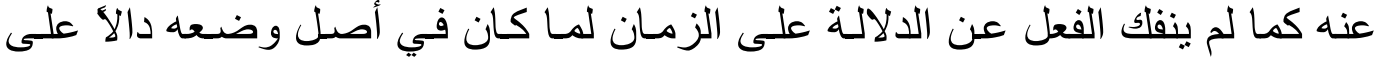

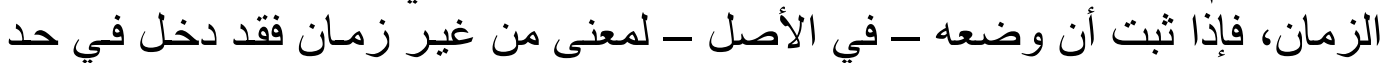

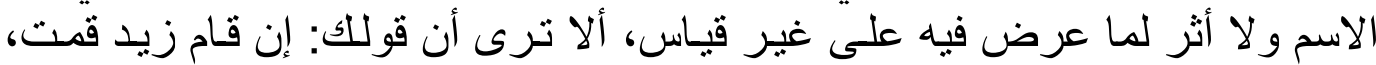

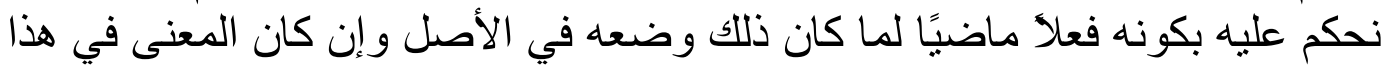

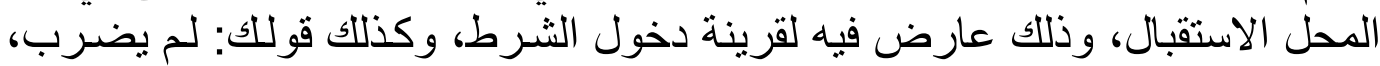

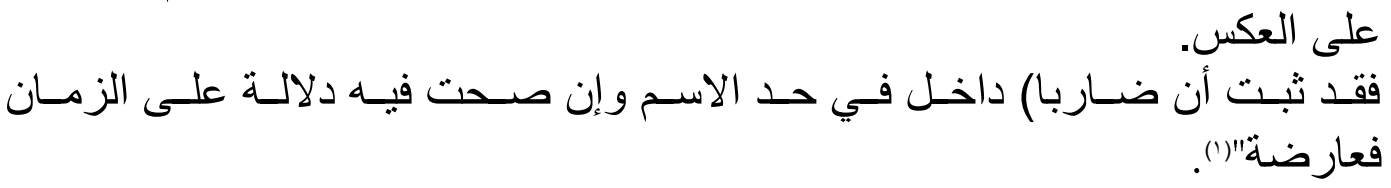

\section{ع- الأفعال لا تقع إلا همكومهاً بهها لا همكومهاً عليـها:}

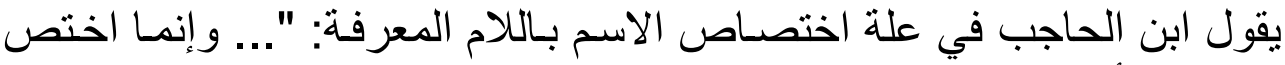

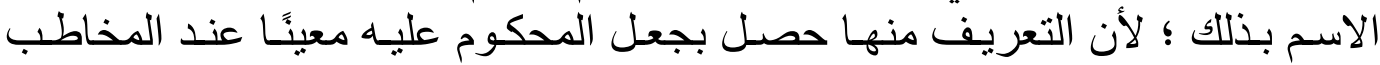

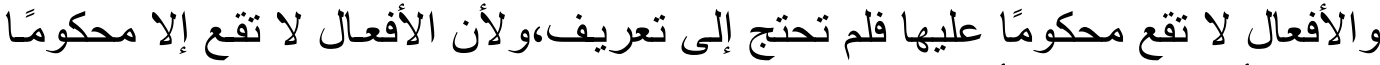

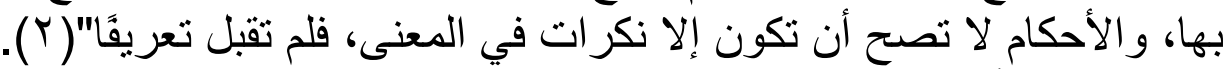

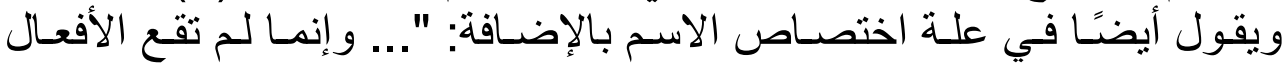

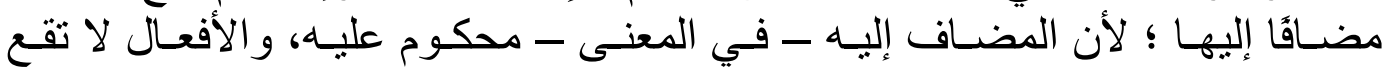

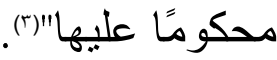

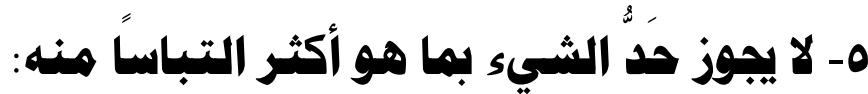

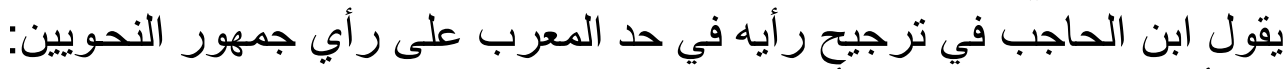

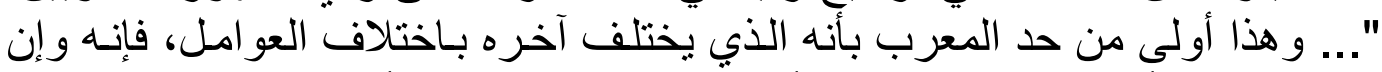

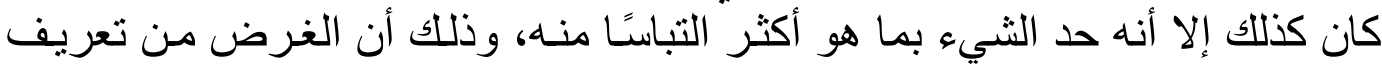

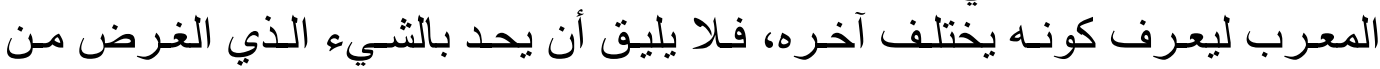

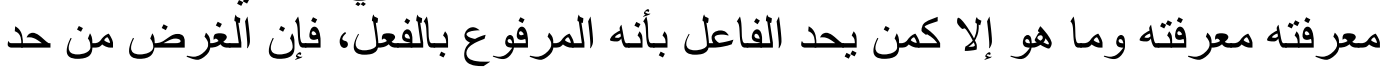
الفاعل أن يعرف ليرتفع، فلا يليق حده بالرفع" (s).

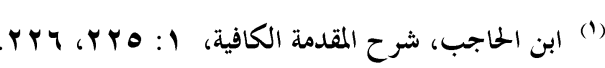

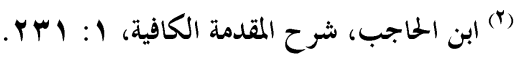

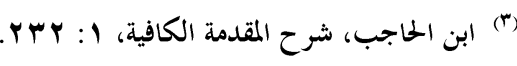

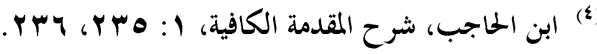




\section{1- الأسماء تطرأ عليها همعان هختلفة بالتركيب:}

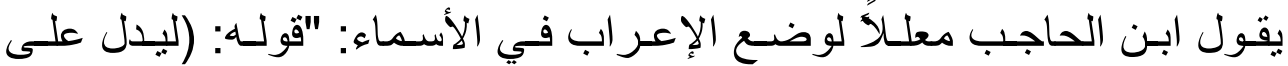

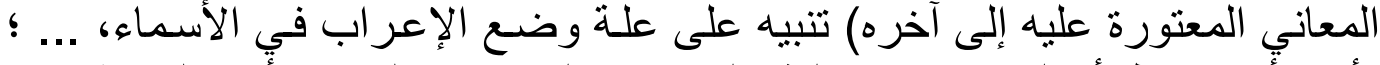

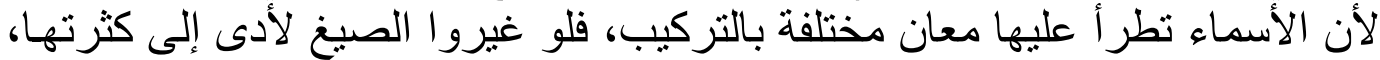

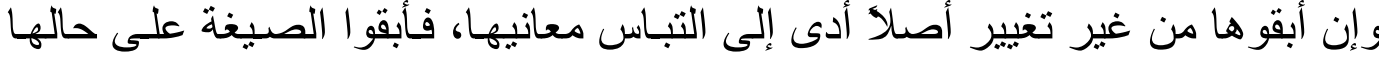

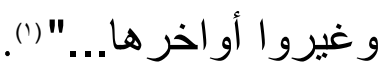

\section{V- الإضافة إلى الاضشمر لا توجب بناء:}

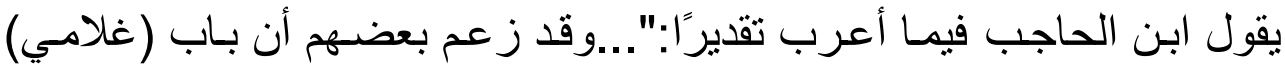

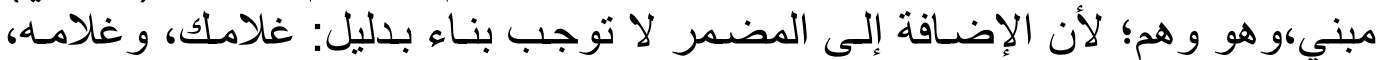

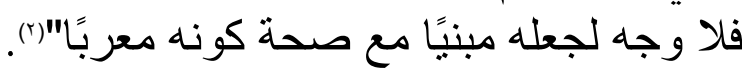

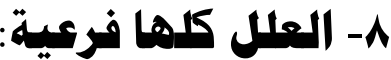

يقول في باب غير المنصرف: "قولها: (وحكمـه أن لا يدخله كسر و ولا تنوين)

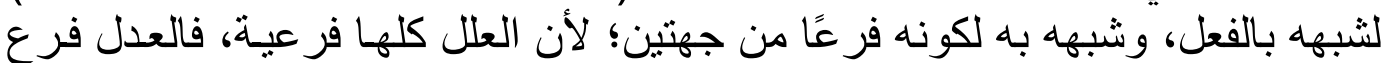

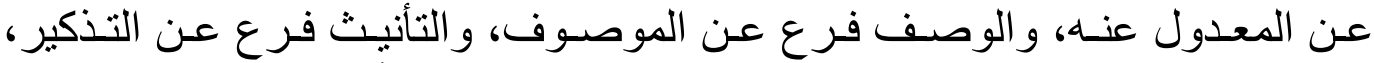

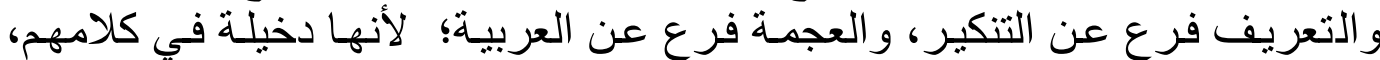

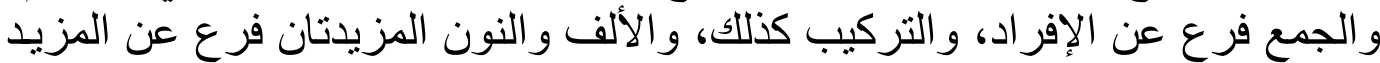

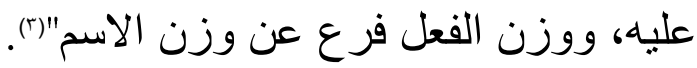

و إذا ثبت أنها فروع وحصل فرعل في الاسم اثنان منها صنار بهما فر عا من من جهتين،

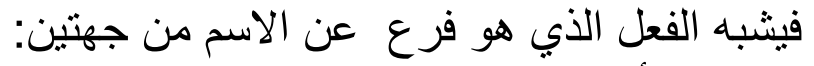

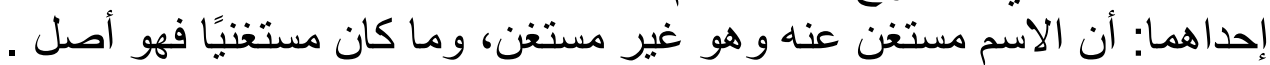

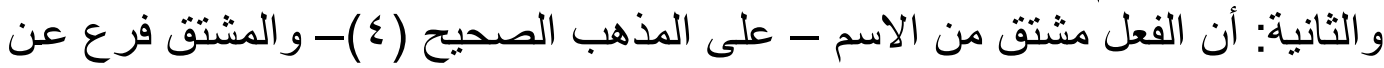
المشتق منه، فلما أثنبه الفعل قطع عما ليس في الفعل وهو الجر و التنوين"(ه).

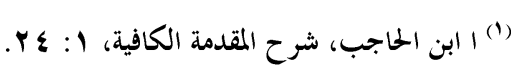

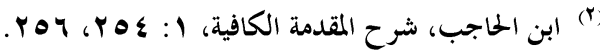

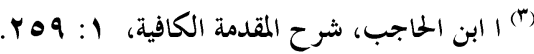

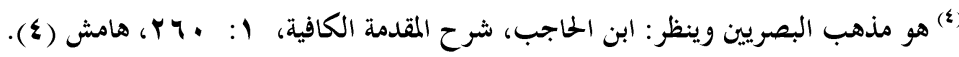

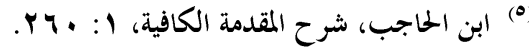




\section{9- ها كان هصتغنيًا فهو أصل:}

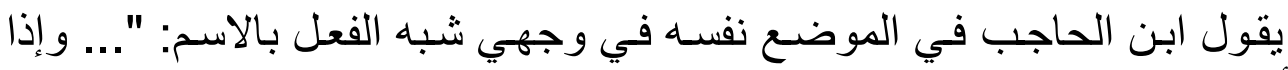
ثبتت أنها فروع وحصل في الاسم اثنان منها صار بهما فرعًا من جهتين، فيثبه الفعل فئل الذي هو فرع عن الاسم من جهنين: إحداهما: أن الاسم مستغن عنه و هو غير مستغن، وما كان مستغنيًا فهو أصل ..."(').

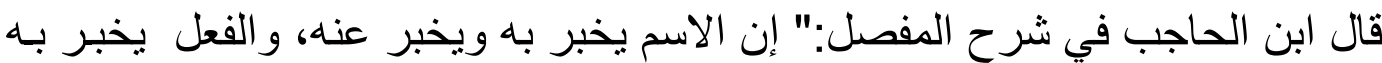

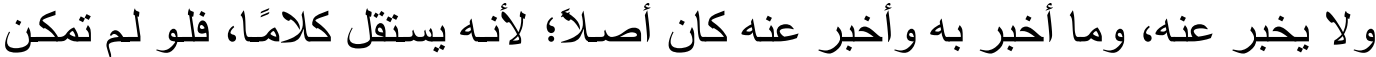

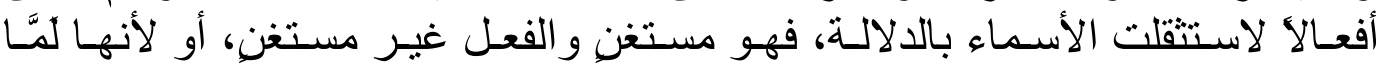

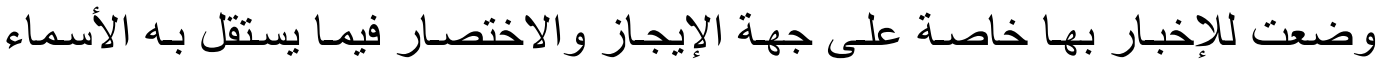

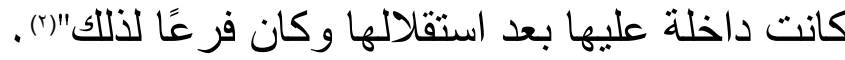

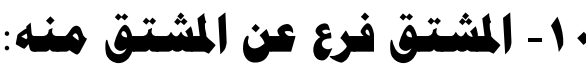

يقول ابن الحاجب في الموضع نفسه: ".... و الثنانية: أن الفعل مشتق من الاستح

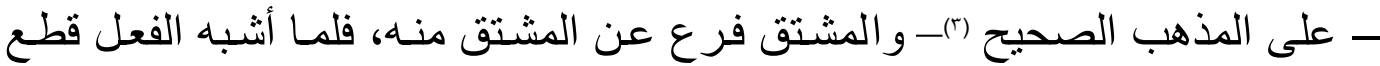
عما لبس في الفعل و هو الجر و التنوين"(().

\section{الا - الضرورة تبيز رَّة الشيء إلى أصله:}

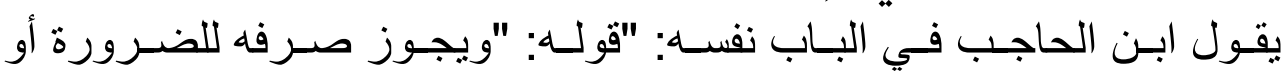

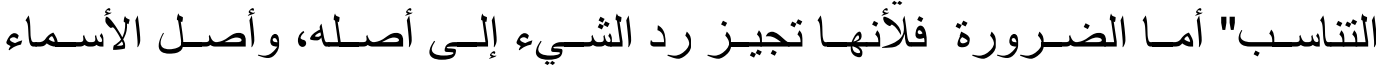

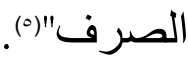

قال ابن يعيش:" فإنَّ ضرورة الثعر تبيح كثيرًا مما يحظره النتر، و واستعمال مـا

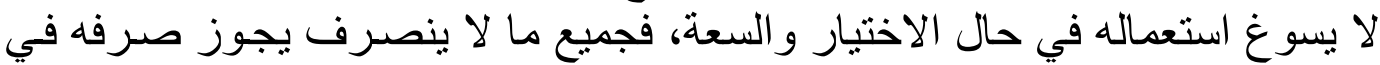

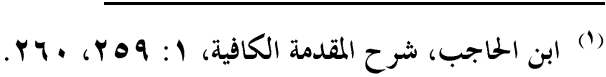

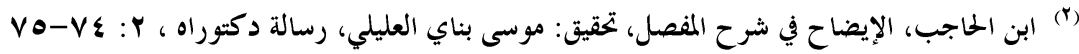

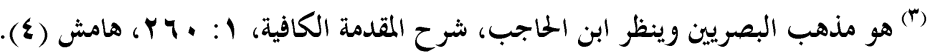

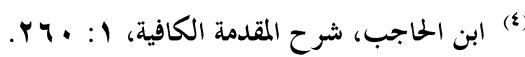

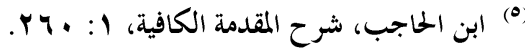


الثعر لإتمام القافية و إقامة وزنها بزيادة التنوين، و هو من أحسن الضرور ات؛ لأنـه

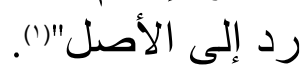

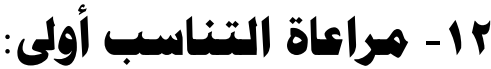

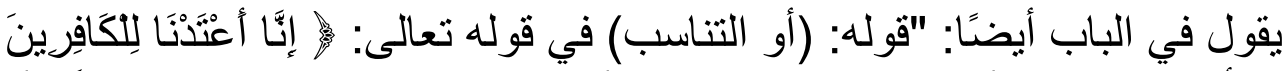

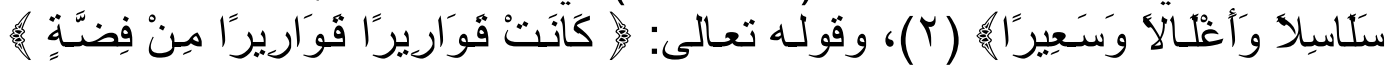

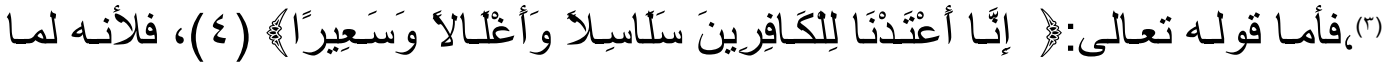
انضم إلى الاسم أسماء منصرفة حسن أن يرد بها إلى ألى أصله مر اعاة للتنتاسب.

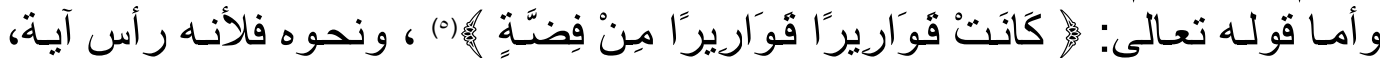

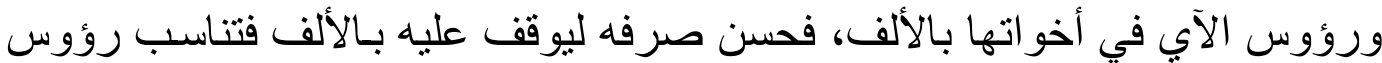

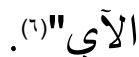

\section{با - النادر لا اعتداد به:}

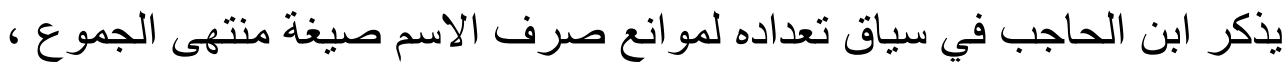

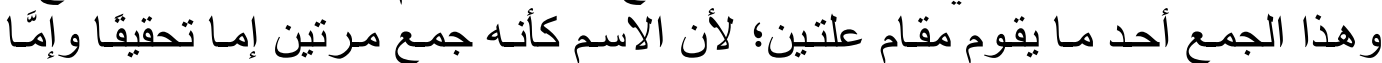

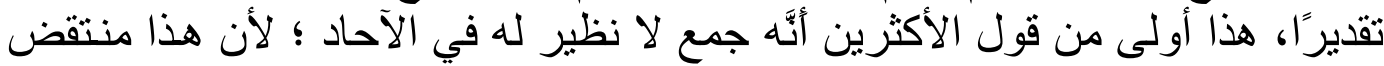

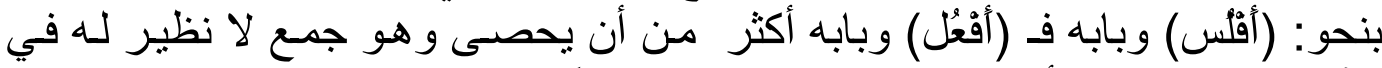

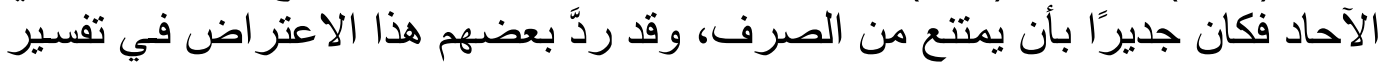

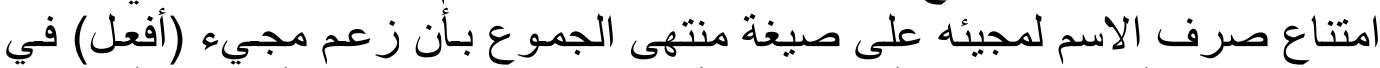

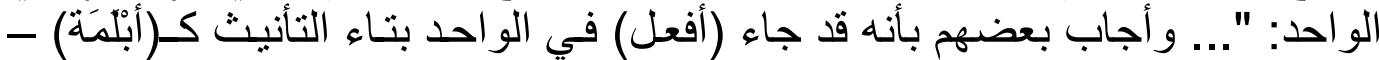

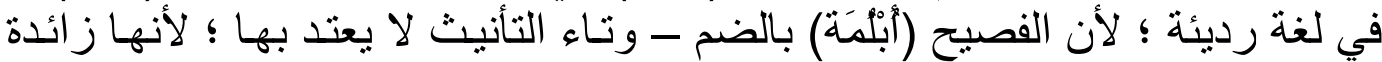

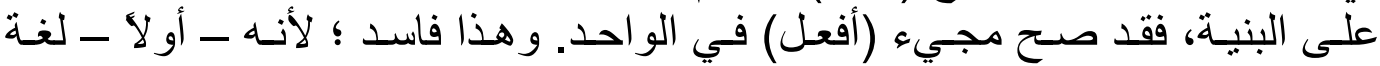

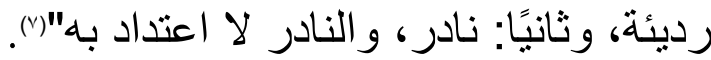

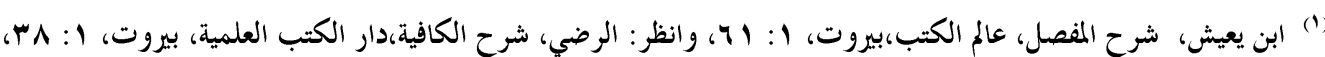

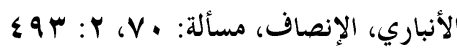

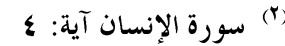

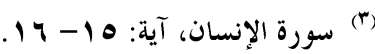

$$
\begin{aligned}
& \text { (\$) سورة الإنسان آية: ع ع الإنسان }
\end{aligned}
$$

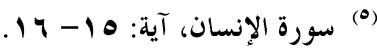

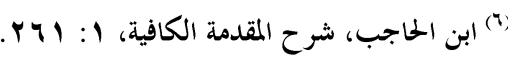

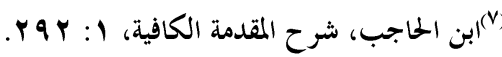


1 - لا أثر للشرط عند فقدان السبب:

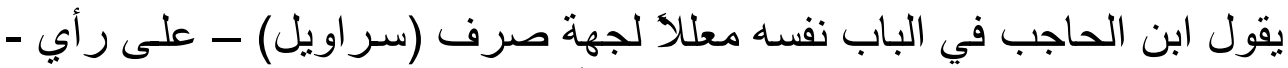

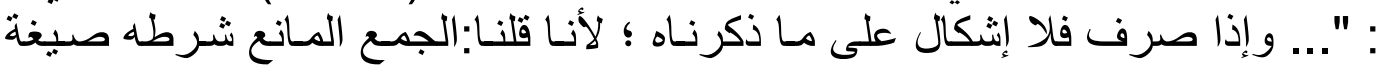

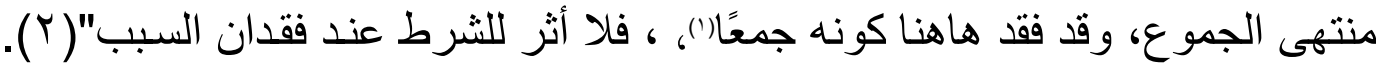

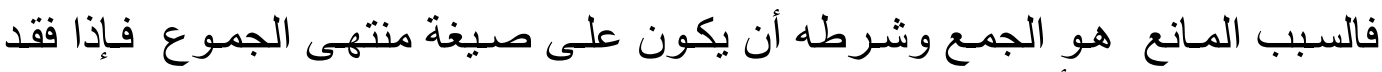
السبب لا يجوز لنا أن نبحث في شرطنه

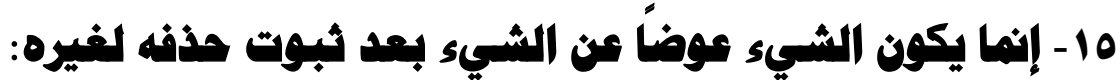

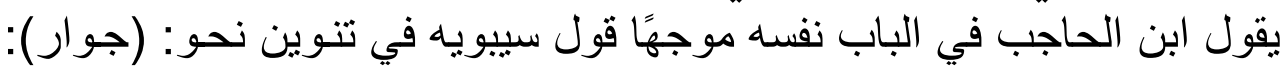

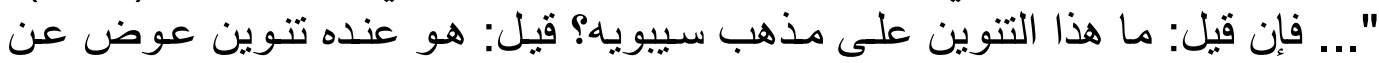

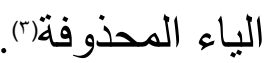

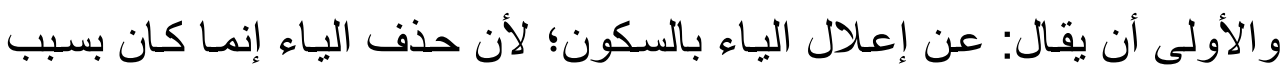

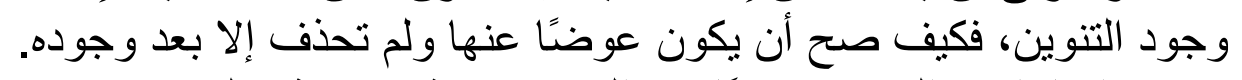

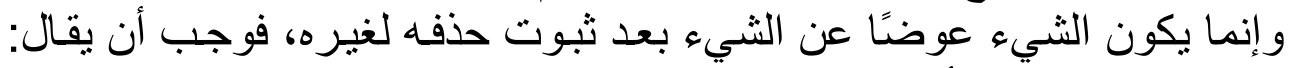

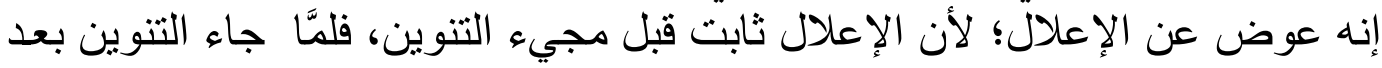
ثبوت الإعلال اجتمع ساكنان، فحذفت الإعاء لإناء لالتقاء الساكنين" (s).

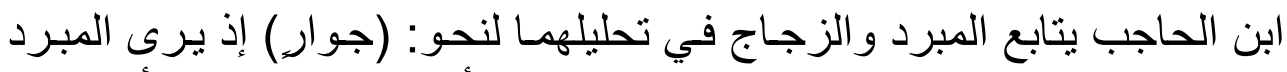

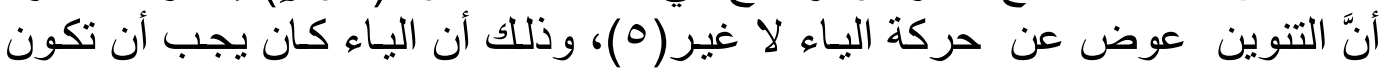

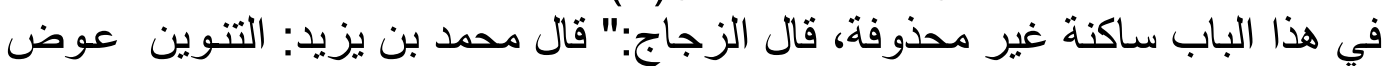
عن حركة الياء لا غير، وذللك أن الياء كان يجب الزب أن تكون في هذا الباب سـاكنة غير

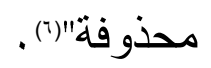

قال الزجاج في موضـع آخر :"الأصل في هذا عند الند النحويين (جواري") بضمة

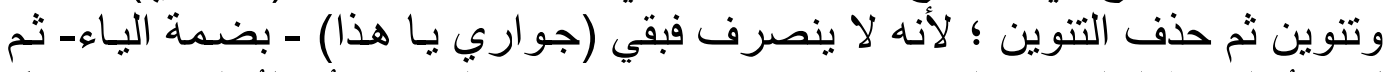

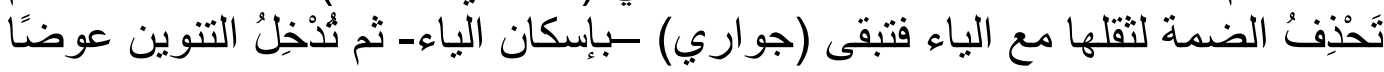

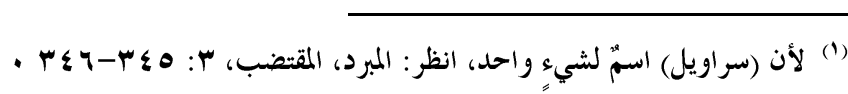

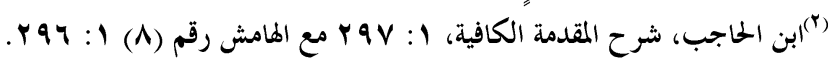

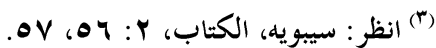

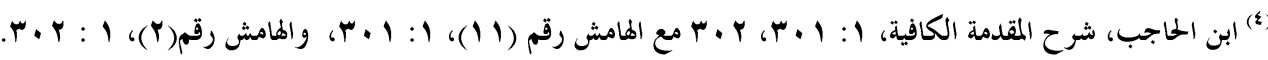

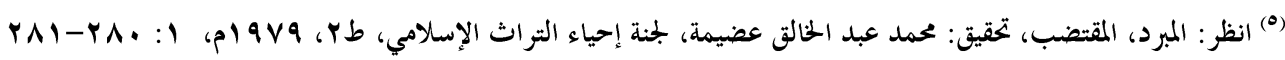

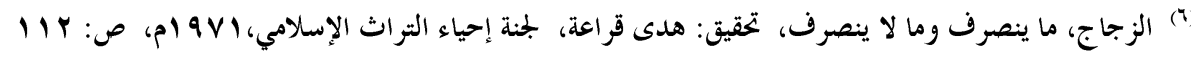




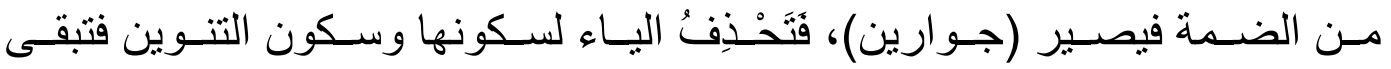

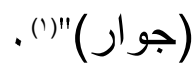

بينما يرى سيبويه أنَّ التنوين عوض عن الياء المحذوفة، يقول:"اعلم أن كل

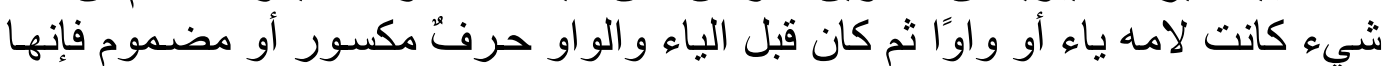

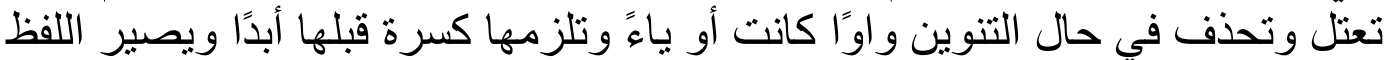

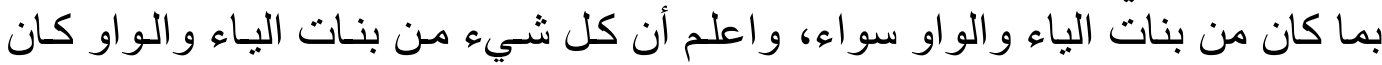

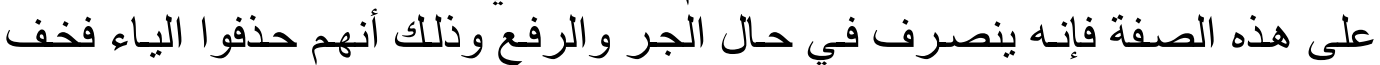

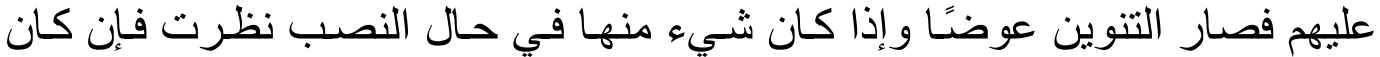

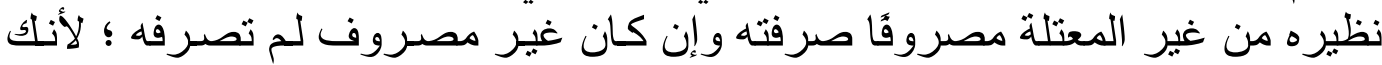
تتم في حال النصب كما تتم غير بنات الياء و والواو "() . .

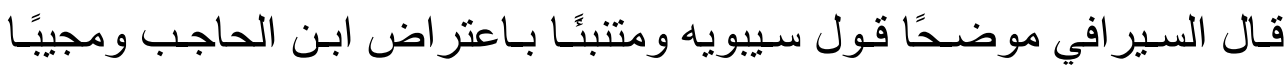

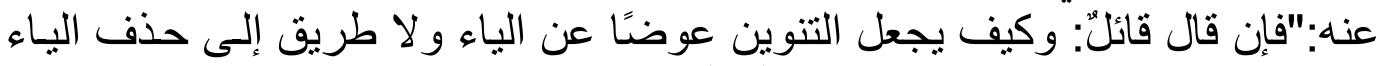

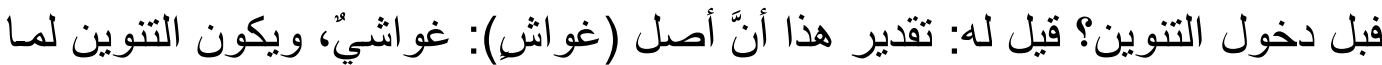

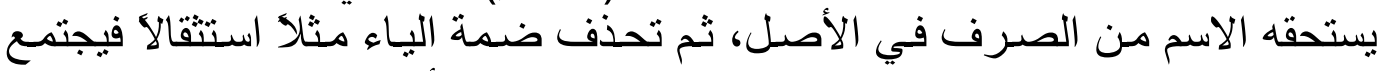

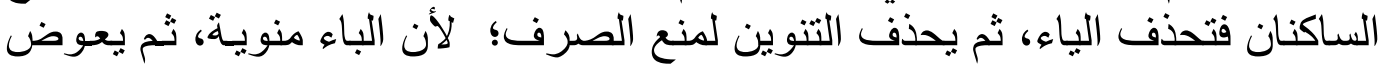

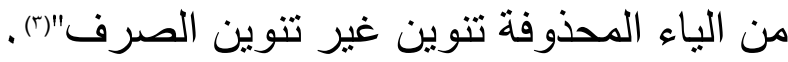

\section{7 - هنه الصرف فرع على الإعراب:}

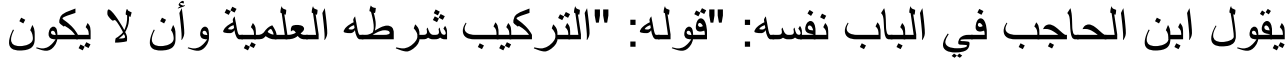

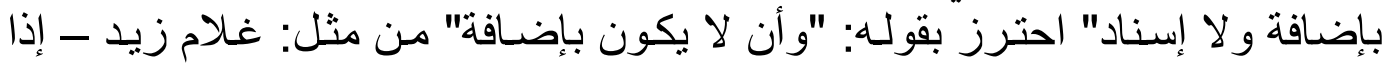

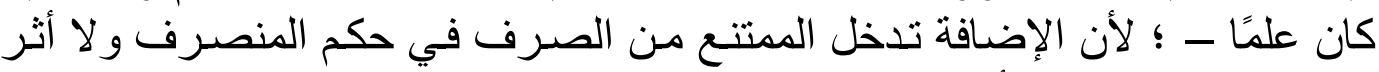

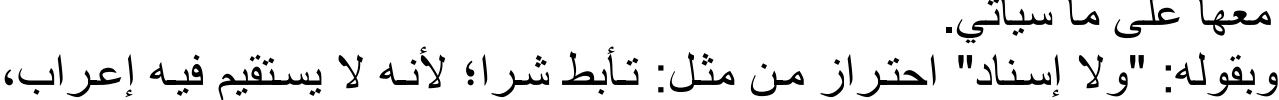

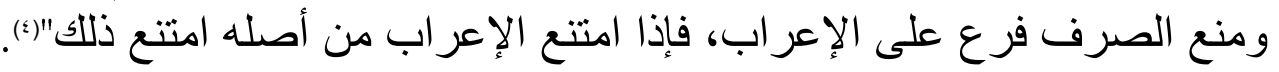

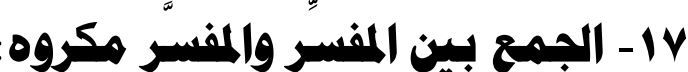

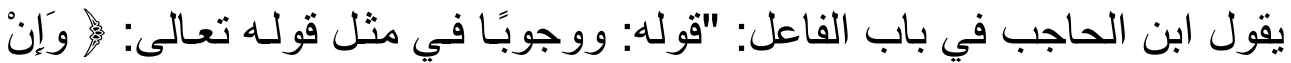

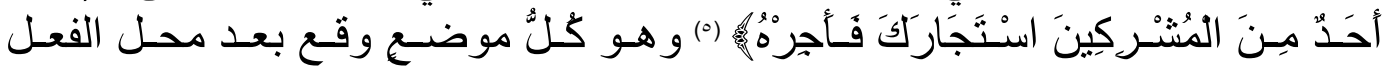

$$
\begin{aligned}
& \text { (1) الزجاج، ما ينصرف وما لا ينصرف، ص: r }
\end{aligned}
$$

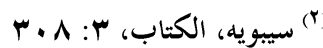

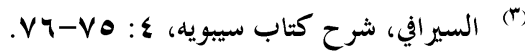

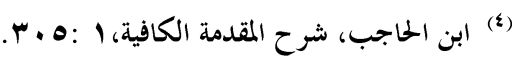

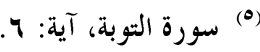


المحذوف فعل أو ما ينزل منزلته مفسر للفعل المحذوف، و إنما التزموا حذفه كر اهية

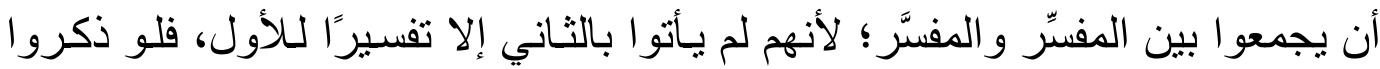

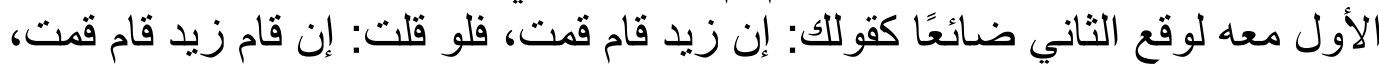

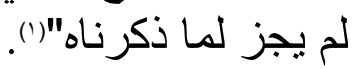

11 - العرب لا تهذف الفاعل:

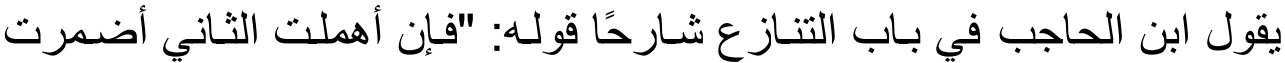

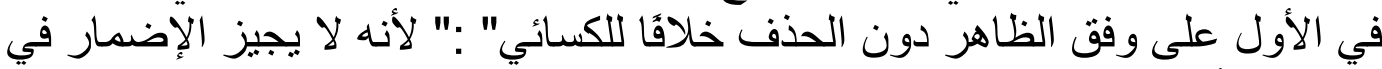

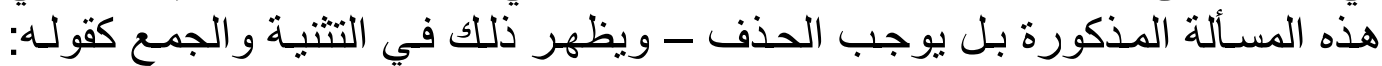

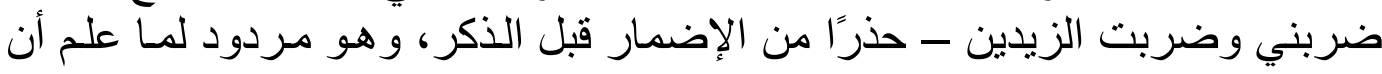
العرب لا تحذف الفاعل"(().

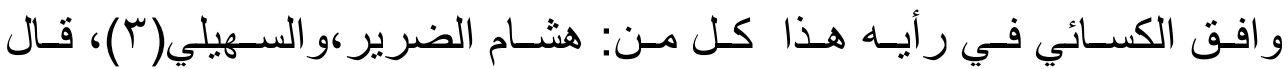

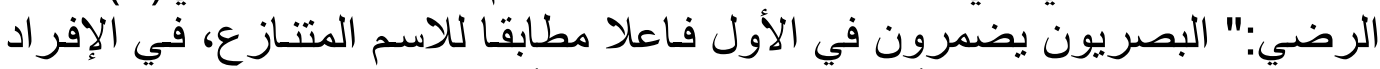

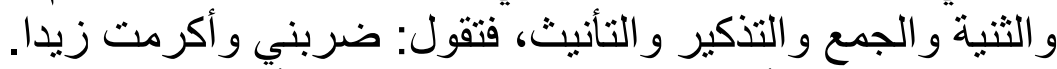

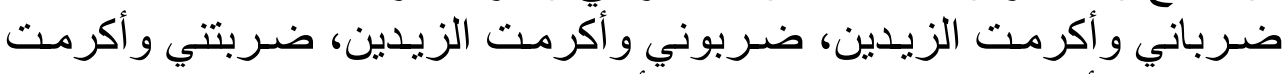

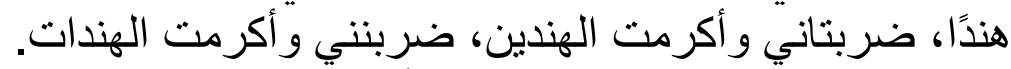

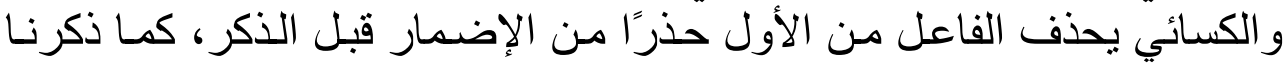

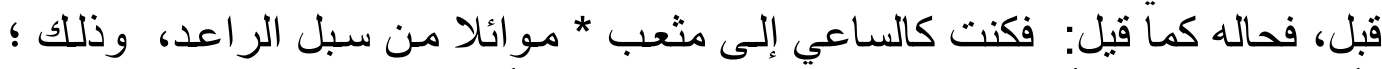

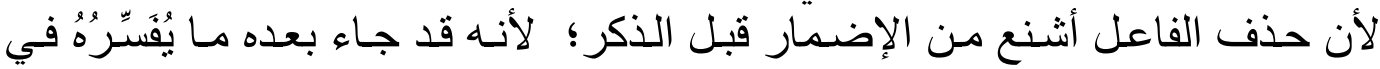

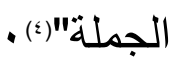

قال ابن يعيش:" لأنَّ الإضمار فيل الذكر قد ورد عليهم في مواضع على إلى

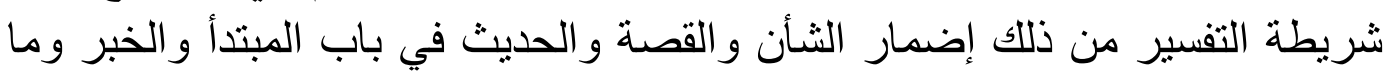

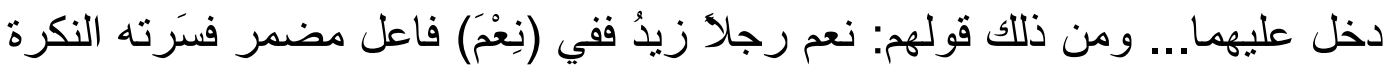

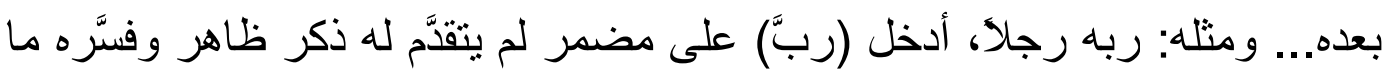

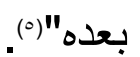

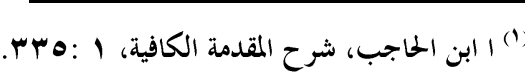

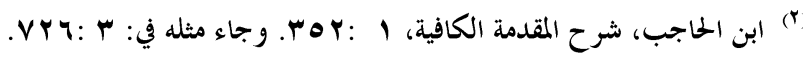

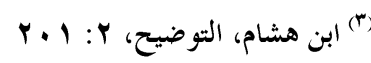

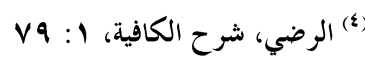

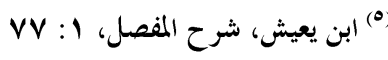


ونقل ابن الحاجب عن الفراء منعه لهذه المسألة لما يلزم عنها من الإضمار قبل

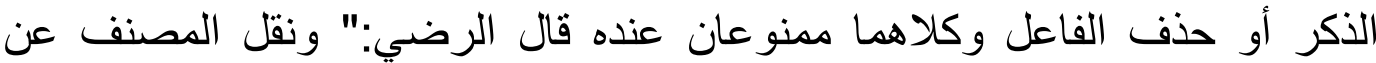

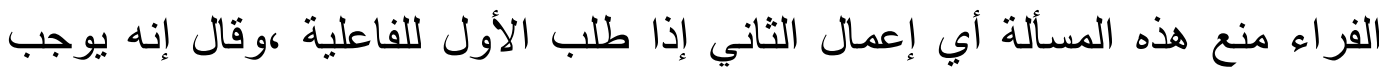

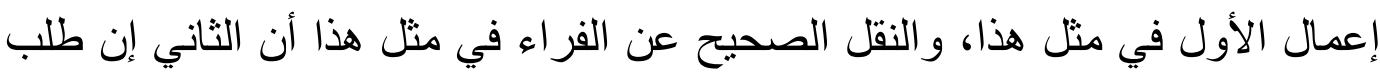

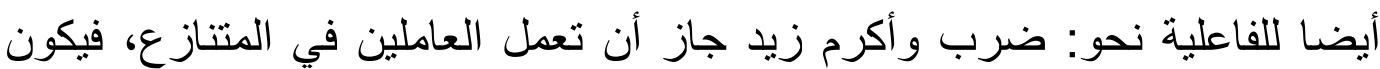

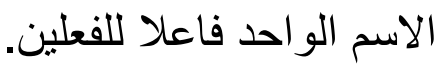

لكن اجتماع المؤثرين التامين على أثر واحد مدلول على فساده في الأصول. وهم يجرون عوامل النحو كالمؤثرات الحقيقية، قال: وجاز أن تأتي بفاعل

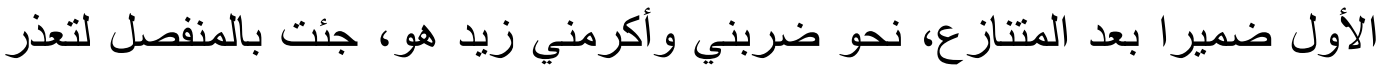
المتصل بلزوم الإضمار قبل الذكر.

و إن طلب الثاني للمفعولية مع طلب الفعل الأول له لأجل الفاعلية. نحو ضربني و أكرمت زيدا هو ، تعين عنده الإتيان بالضمير بعد المتنازع كما رأيت،

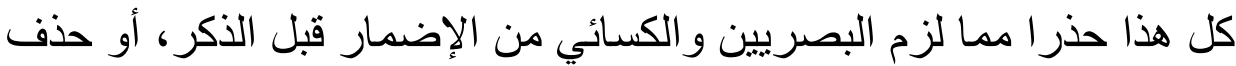

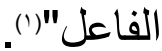

19 - إذا لم يسخ حذف ولا إضهار يجب العدول إلى الظاهر:

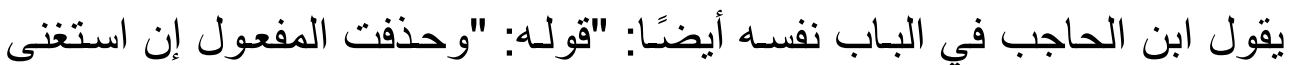

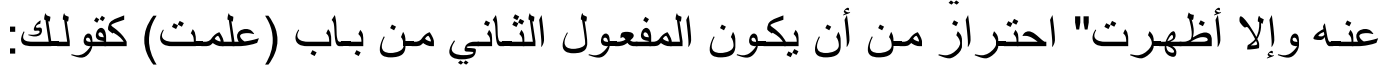

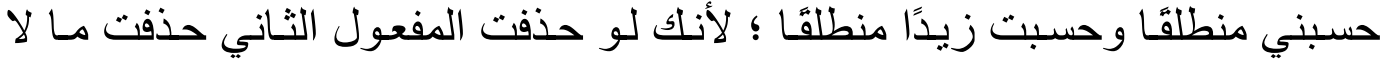

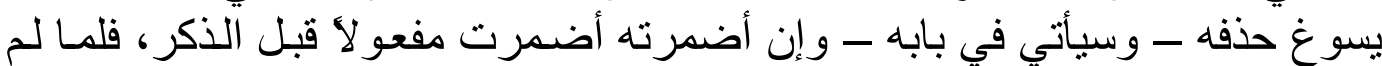
يسغ حذف و لا إضمار وجب العدول في إلى الظاهر"((). قال الرضي:" يعني إذا أعملت الثاني وطلب الأول للمفعولية فالواجب حذف

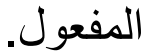

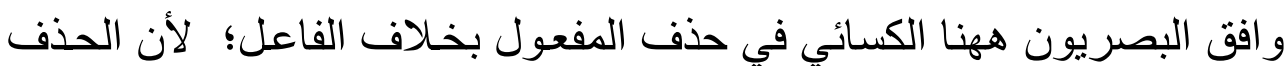

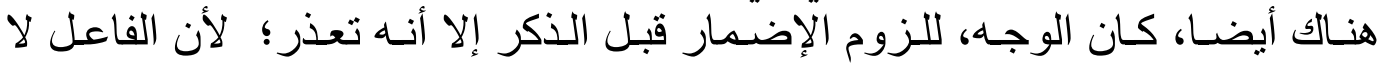

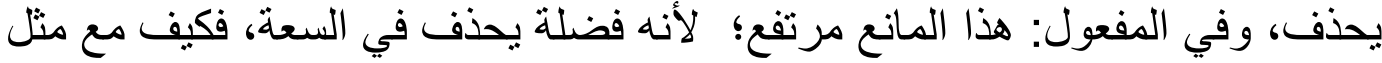

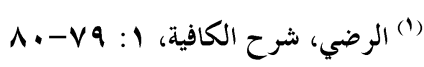

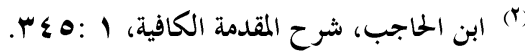


هذا المحوج، أي الإضمار قبل الذكر ، قوله:" إن استغنيت عنه " في مثل: ضربت

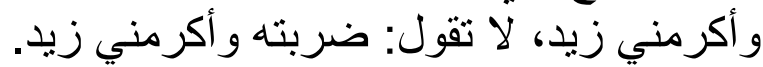

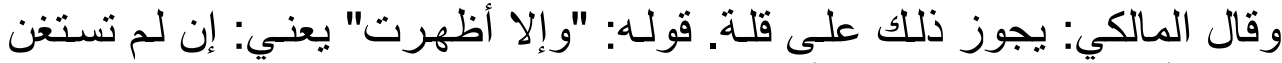

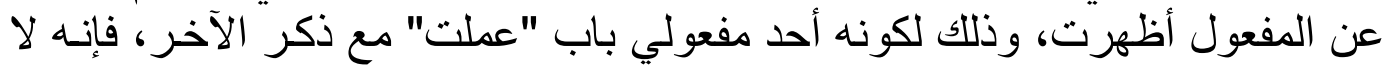

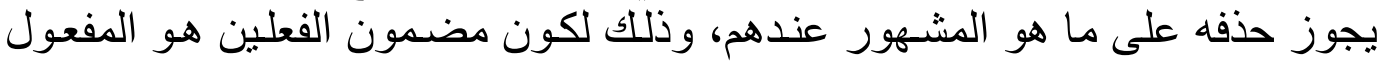

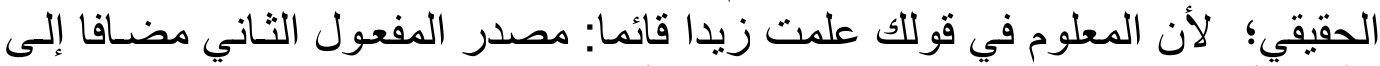

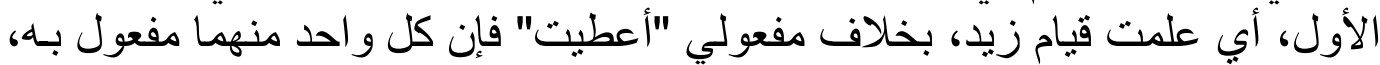

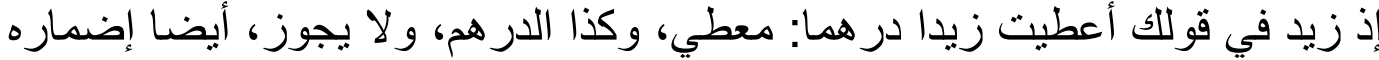

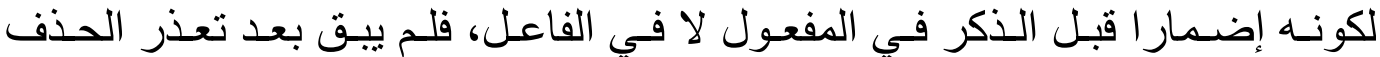
و الإضمار، إلا الإظهار "(ن).

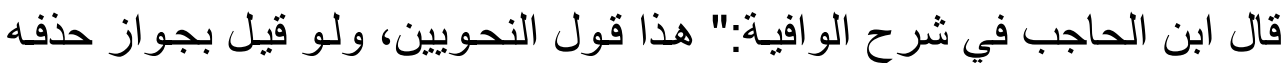
لقيام القرينة في جملته، ولم يكن بعيدًا عن الصواب، كمال فئ يحذف حبر المبتدأ عند قيام

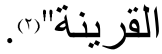

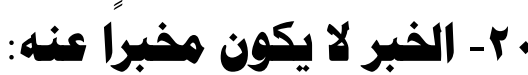

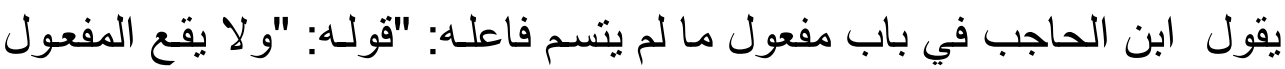

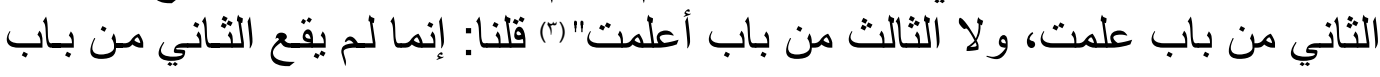

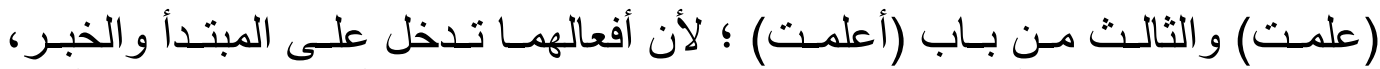

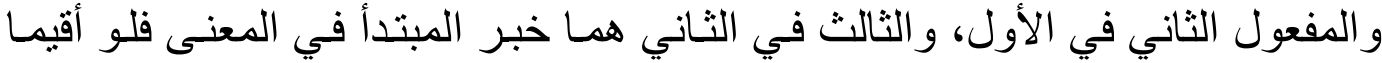
مقام الفاعل لصار مخبرًا عنهما، وهذا باطل؛ لأن الخبر لا يكون مخبرًا عنه"(").

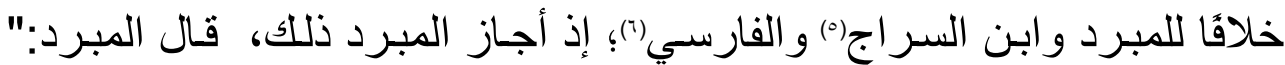

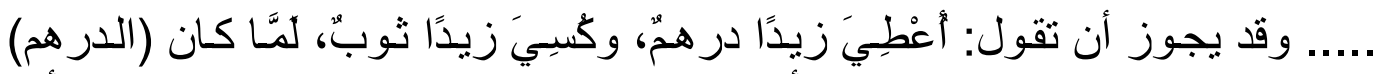

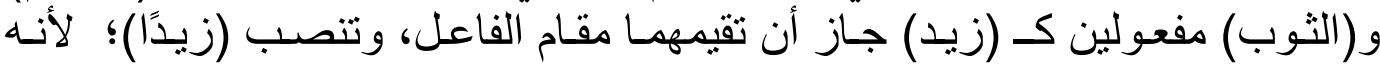

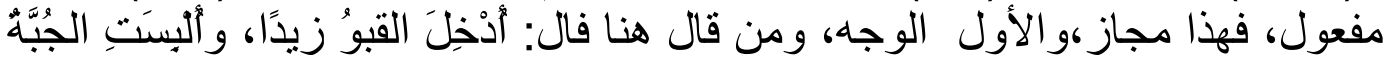

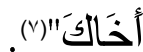

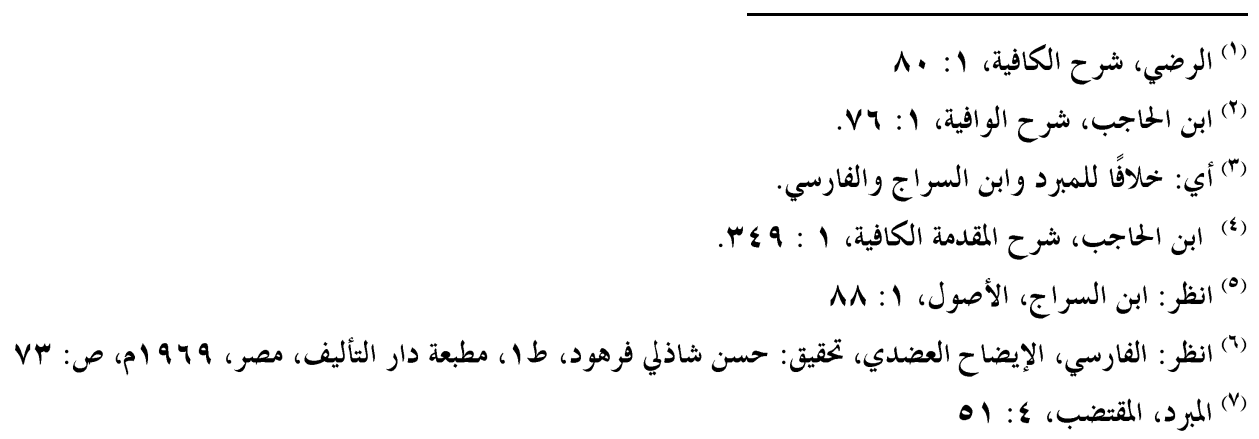




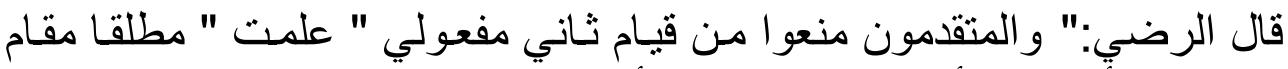

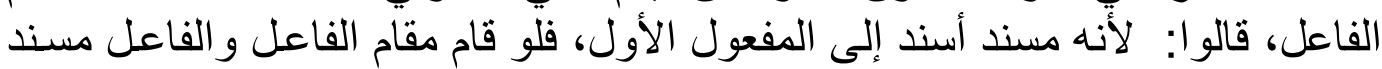

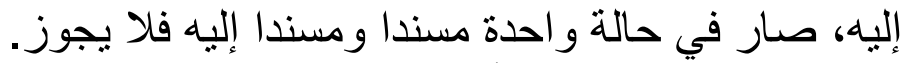

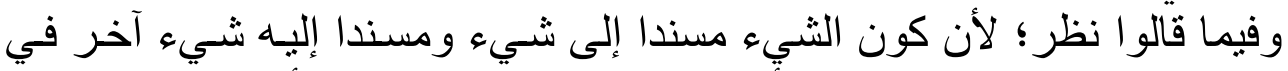

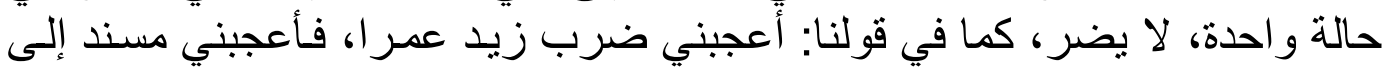

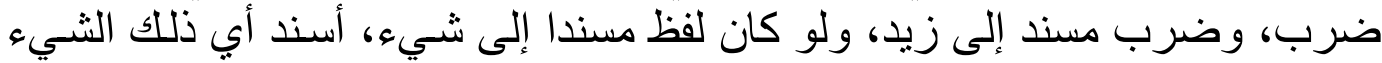

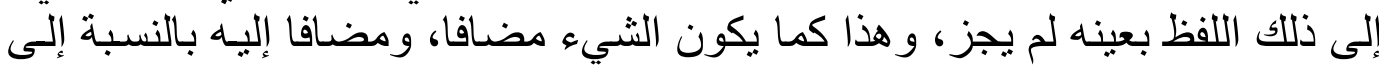

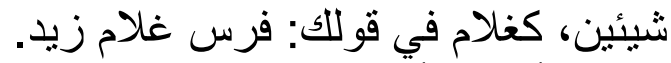

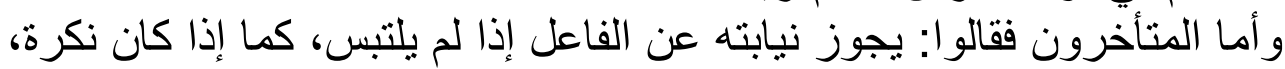

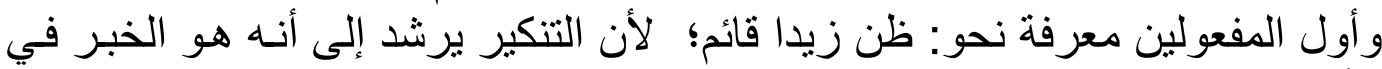

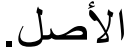
و الذي أرى، أنه بجوز قياسـا نيابته عن الفاعل، معرفة كان أن أو نكرة، و اللبس

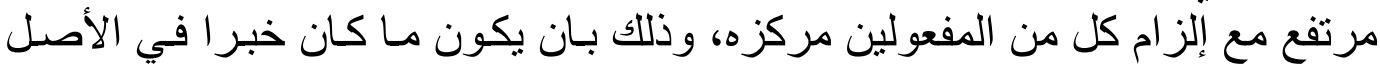

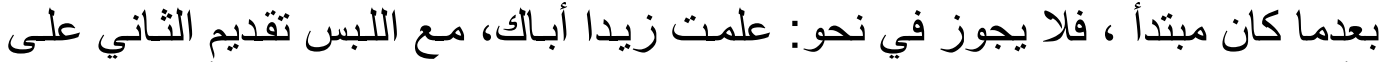

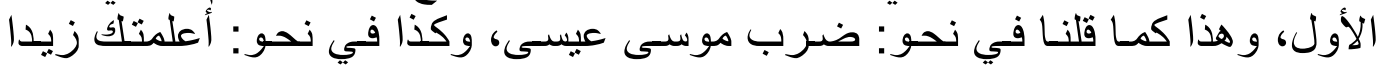

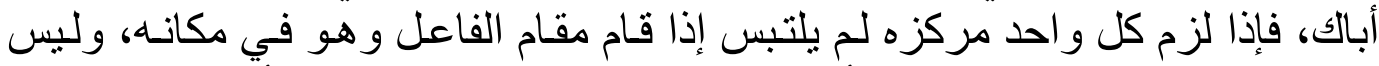

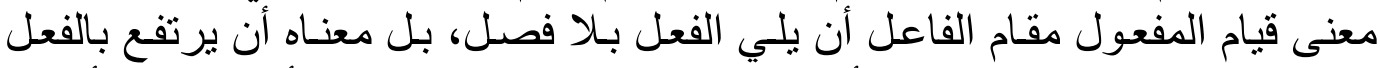

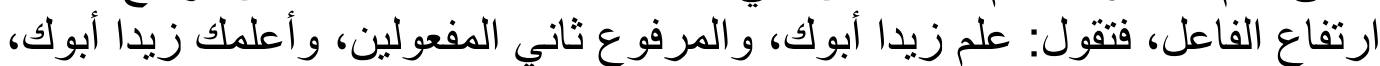

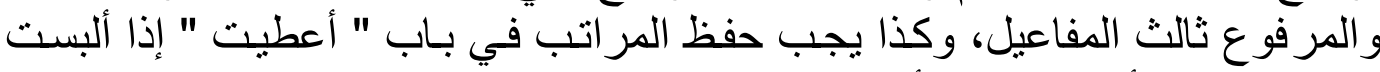

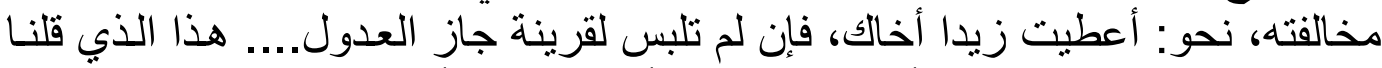

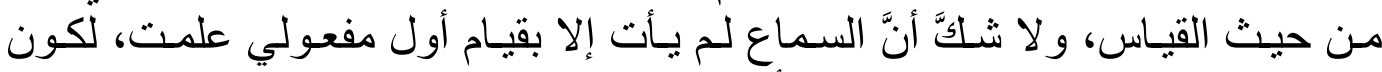

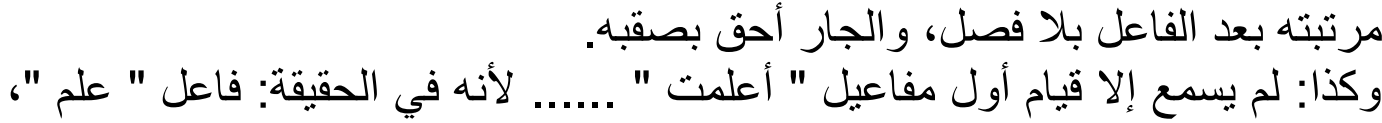

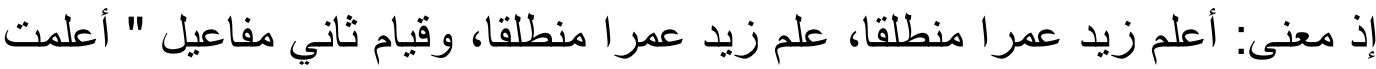

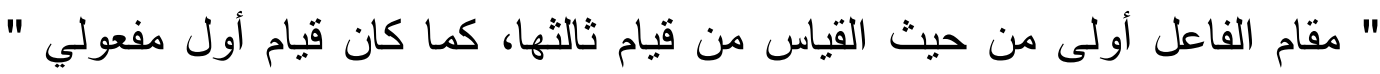

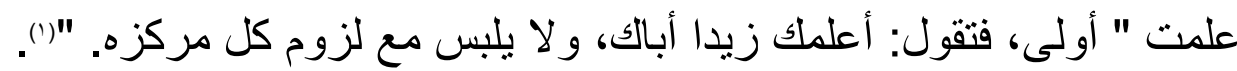

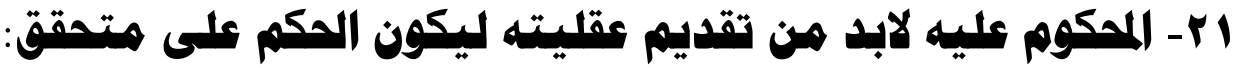

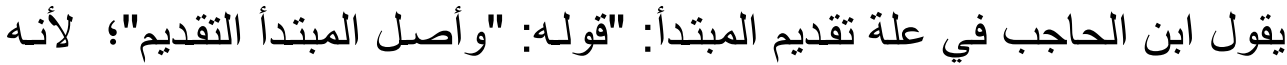
المحكوم عليه فلابد من تقديم عقليته ليكون الحكم على متحقق" (').

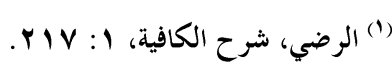

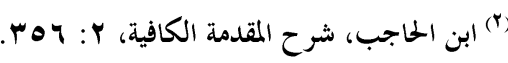




\section{rr يتسع في الظروف ها لم يتسع في فيرها:}

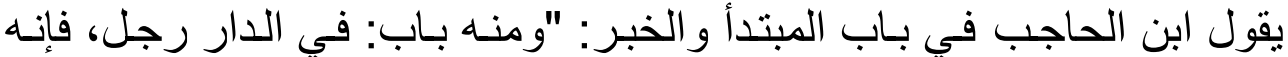

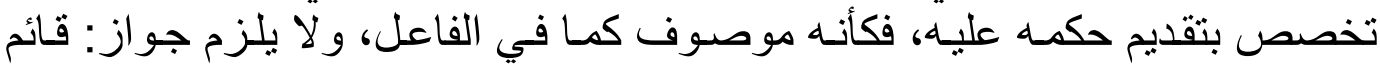

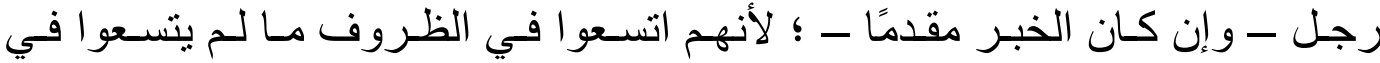

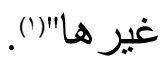

\section{rr- يموز هذف الضمير إذا كان همعلوما:}

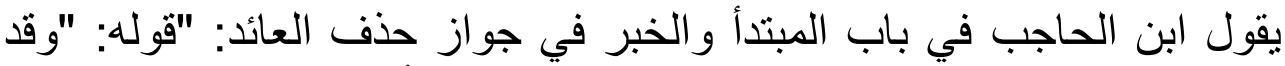

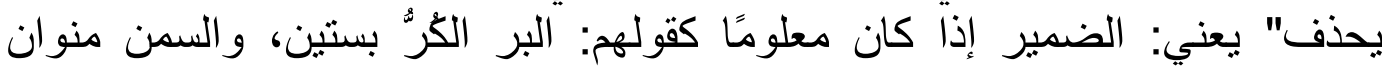

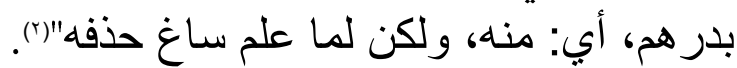

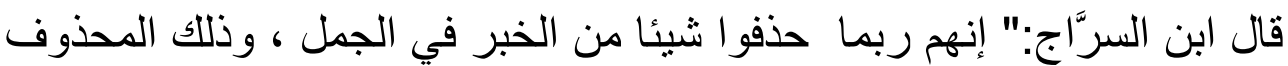

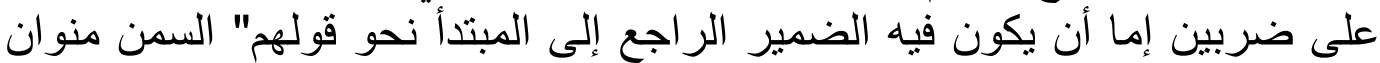

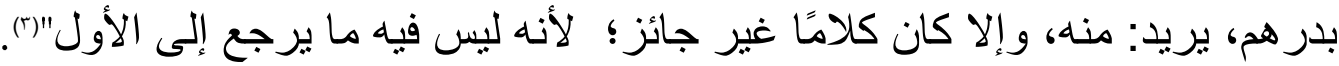

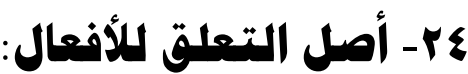

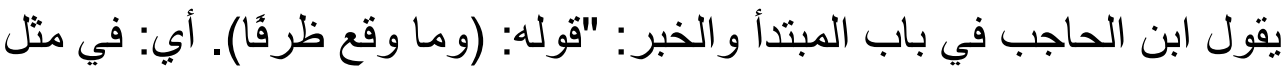

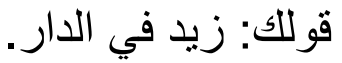
قوله: "فالأكثر أنه مقدر بجملة" نظرًا إلى أنه متعلق و أصل التعلق للأفعال"(s).

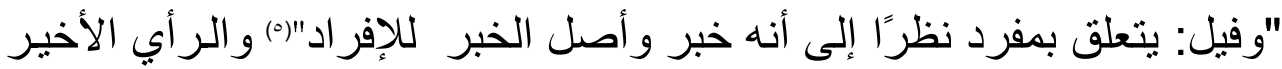

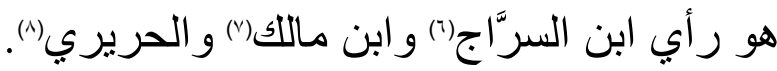

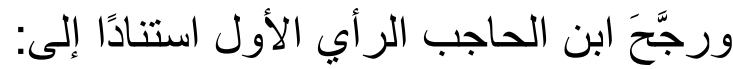

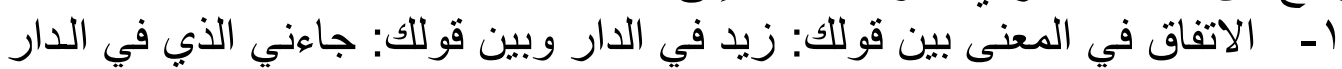

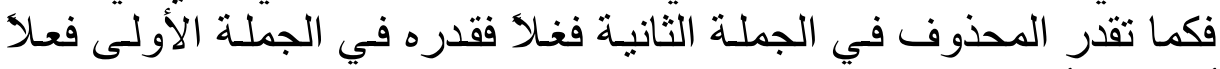

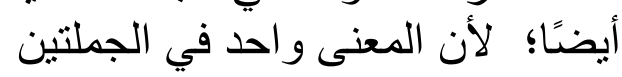

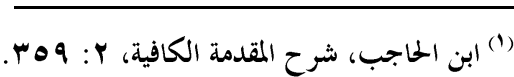

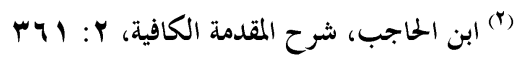

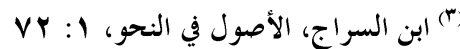

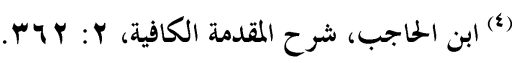

$$
\begin{aligned}
& \text { (o) }
\end{aligned}
$$

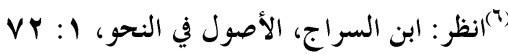

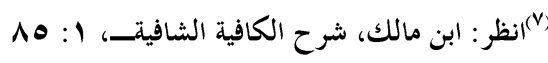

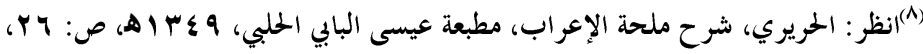




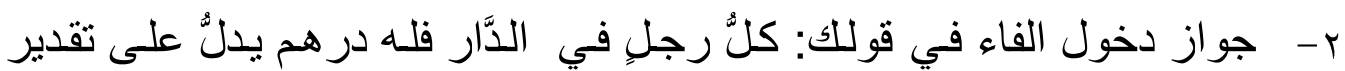

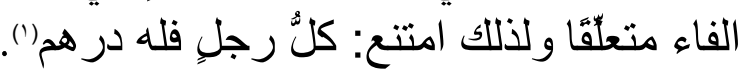

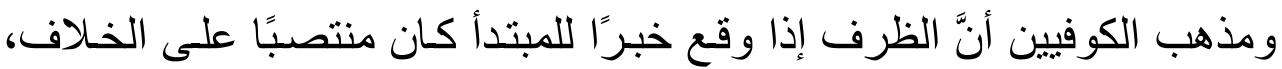

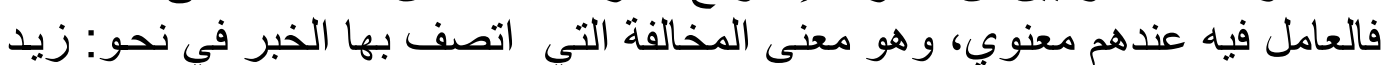

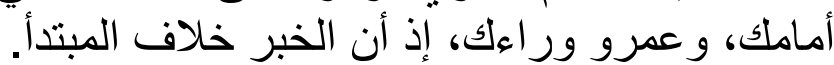

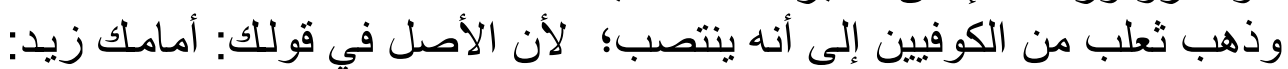

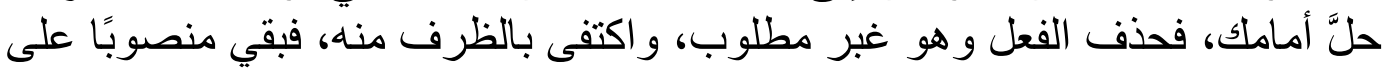

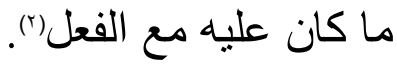

\section{مr - قد يمكم على الشيs بأحكام هتعددة:}

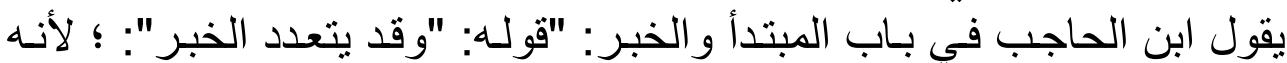
حكم، وقد يحكم على الثيء بأحكام متعددة كما في الصفات" (ت).

\section{1 الحذف واجب عند توفية المعنى والالفظ جميهاً:}

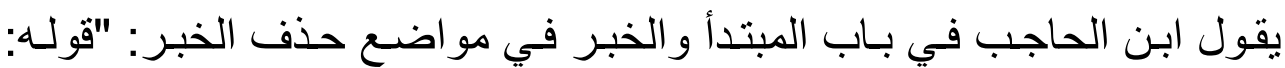

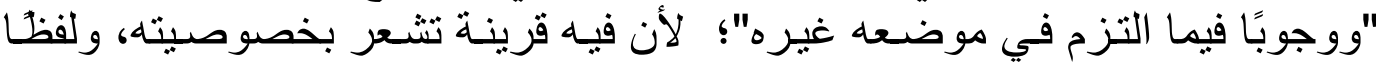

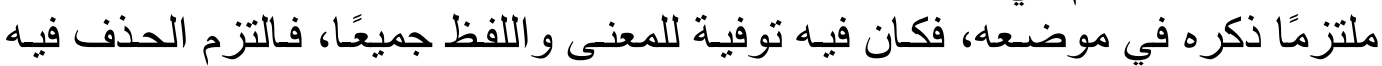

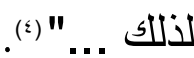

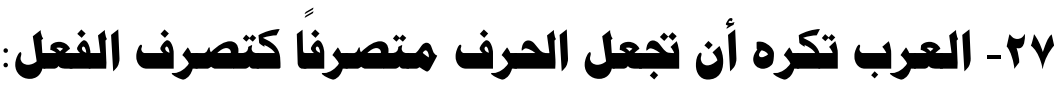

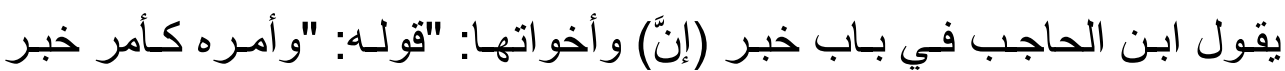

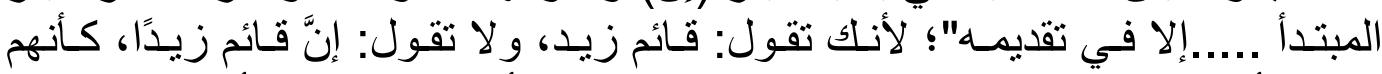

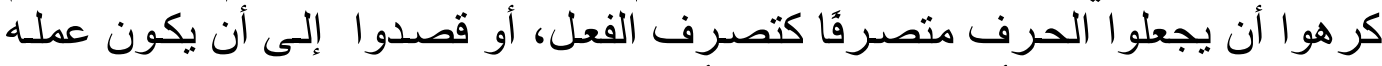

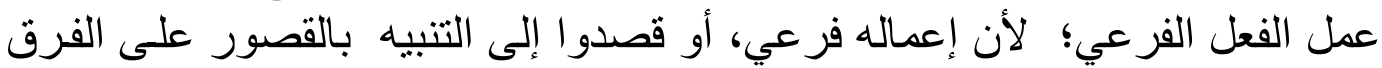

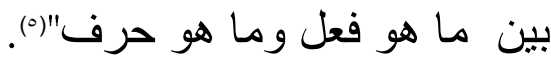

1 - م- ها زال عنه الاحتمال يمسن التمثيل به:

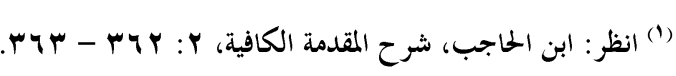

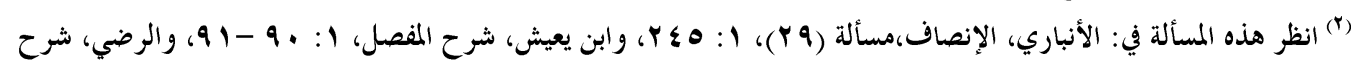

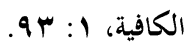

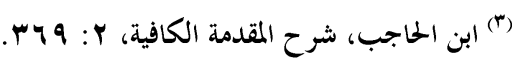

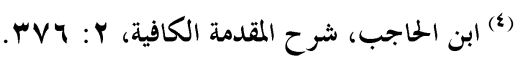

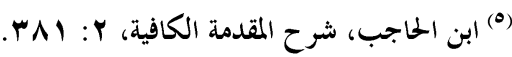


يقول ابن الحاجب في باب خبر (لا) التي لنفي الجنس: "قولـه: "مثنل: لا غـلام

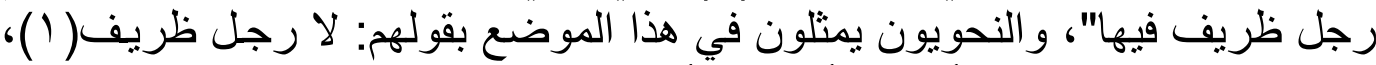

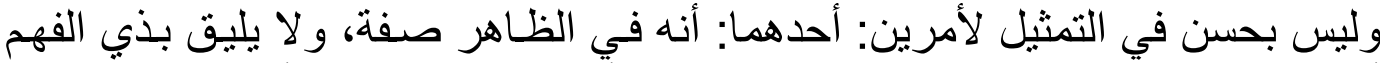

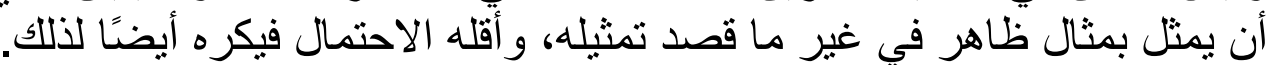

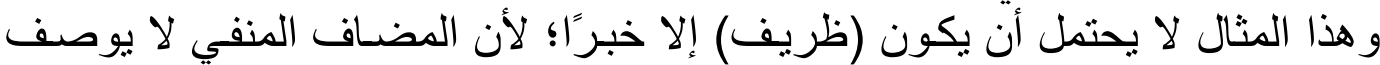
إلا بمنصوب(r)، فوجب أن لا يكون صفة، فز ال ال الاحتمال عنه فحسن التمثيل به" ((r).

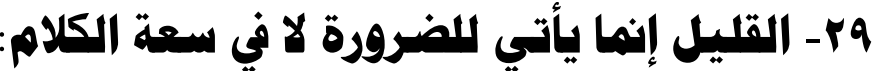

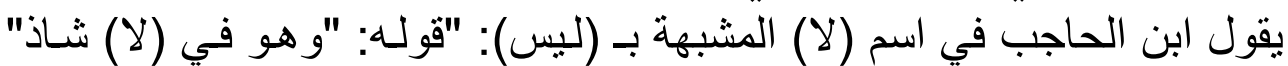

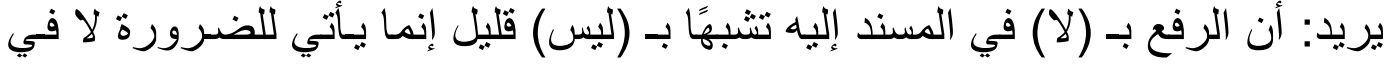

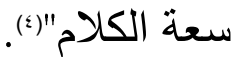

\section{r. r. - ما وضع لالصقيقة يتعذر تثنيته وجمعه:}

يقول ابن الحاجب في علة تثنية المفعول المطلق المؤكد لعامله: "قولـه: "فالأول

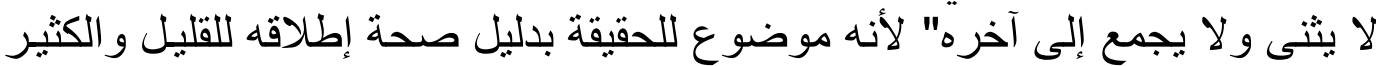

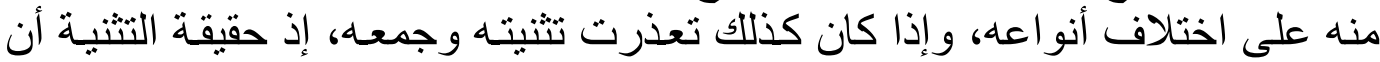

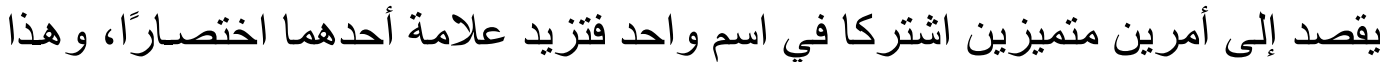

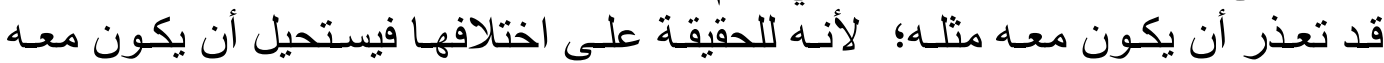
من" (0) (0)

\section{ا اب - عمل الفعل أصل فيتصرف في هعموله:}

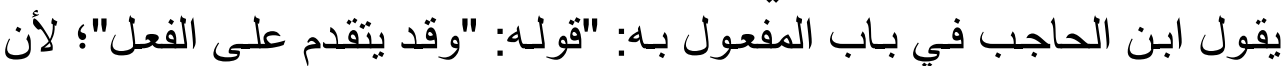

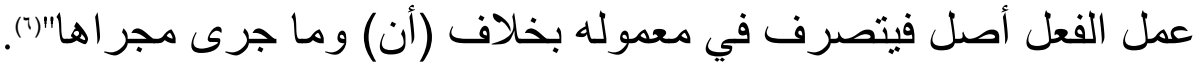

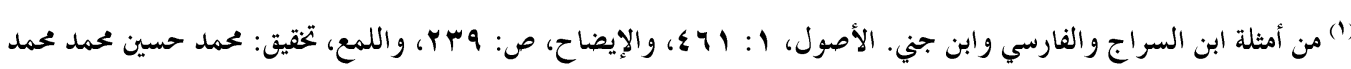

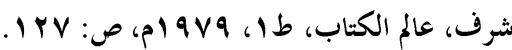

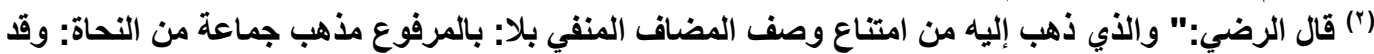

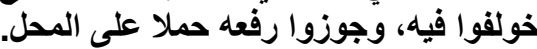
وذلك ؛ لأن " لا " هذه مشبهة بان، فكما يجوز في توابع اسم " إن "- وإن كان معرباـ الحمل على المحل، فكذا

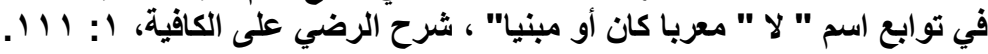

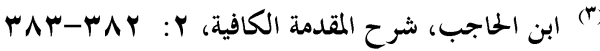

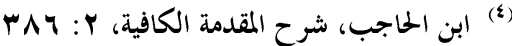

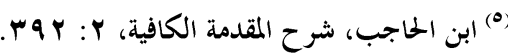

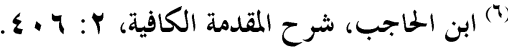


r r مرف الجر لا يمكن إلغاؤه:

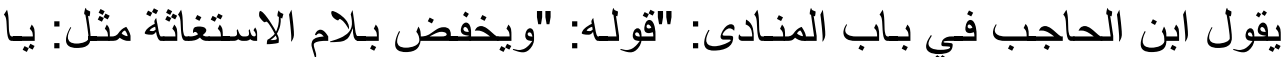
لزيد" لأن حرف الجر لا يمكن إلغاؤه فكان اعتباره أولى" (').

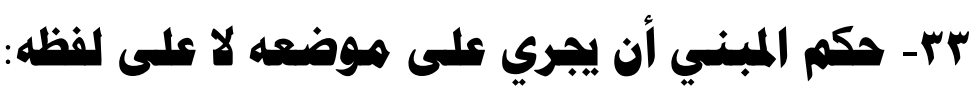

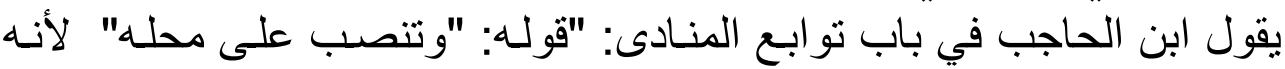

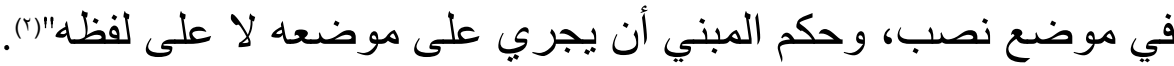

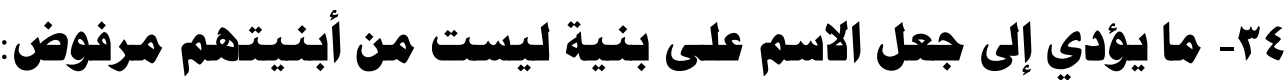

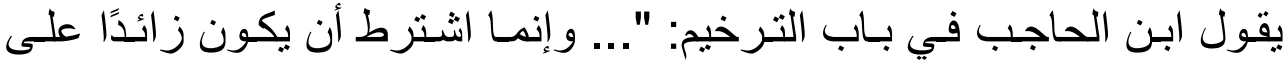

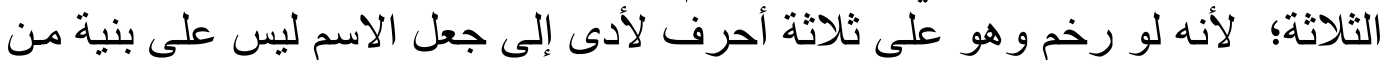

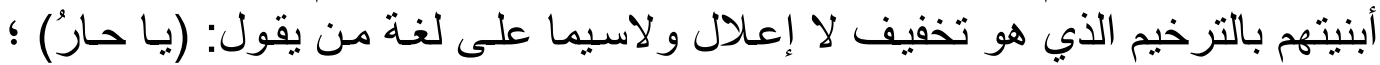
لأنه عند هم اسم بر أسهة" (5).

\section{هr- إذا زال العارض بقي الأصل:}

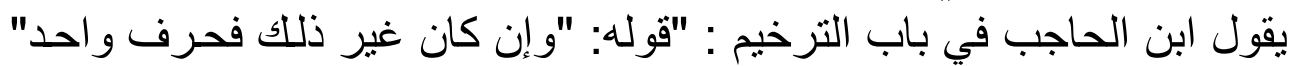

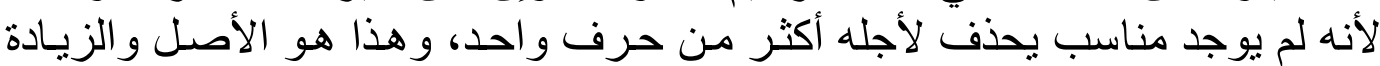

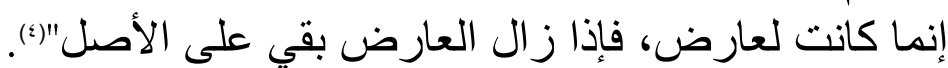

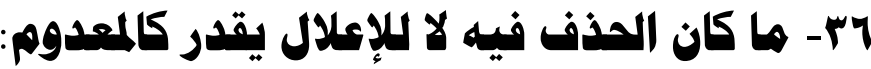

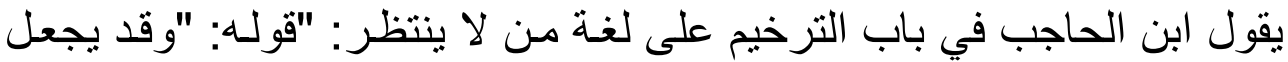

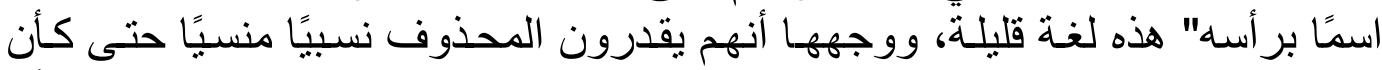

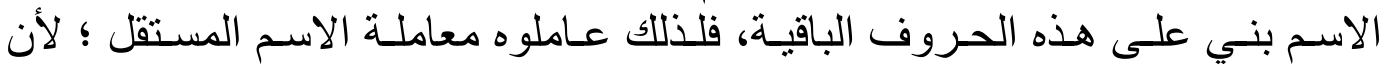

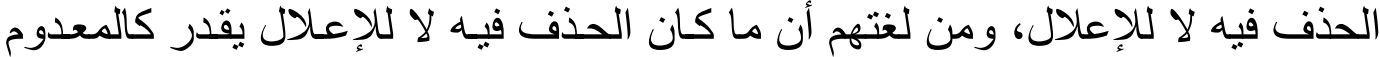

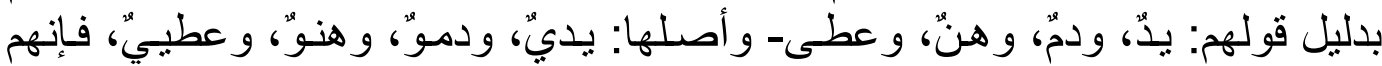

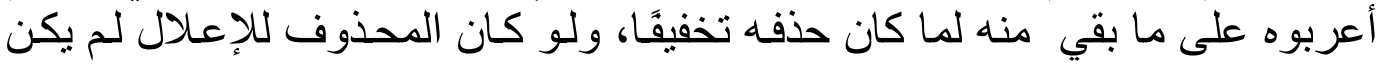
كذللك.... فهذا وجه ظاهر يقوي هذه اللغة مستقر أ من لغتهم ..." (م).

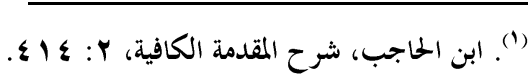

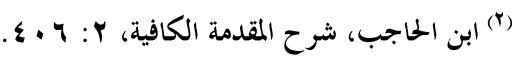

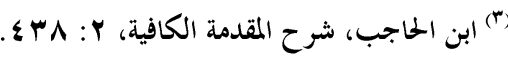

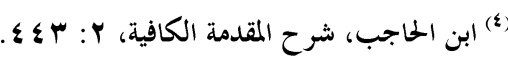

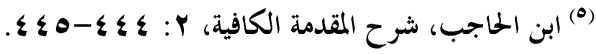




\section{r - المنصوص عليه بمكم لا يدخل همه غيره:}

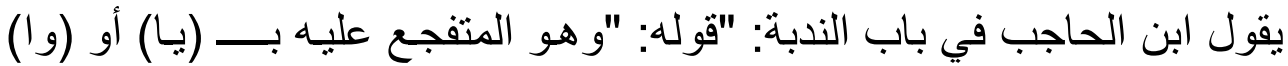

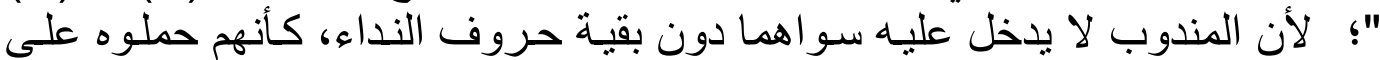

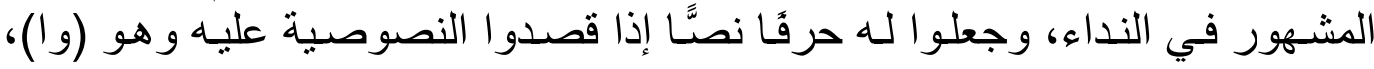

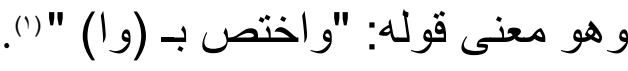

\section{ي - م- ها يوجب الببس يعدل عنه:}

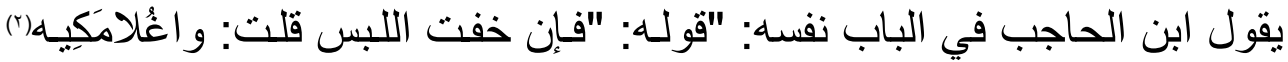

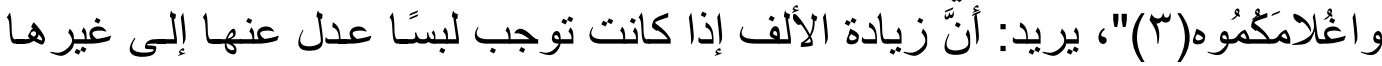

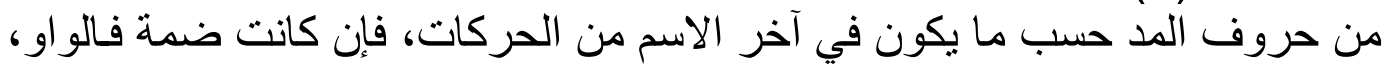

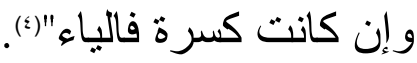

\section{qr- عدم الجمع بين وجوه هن المذف كراهة الإخلال:}

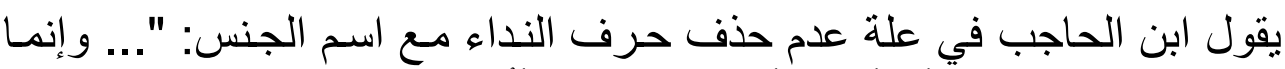

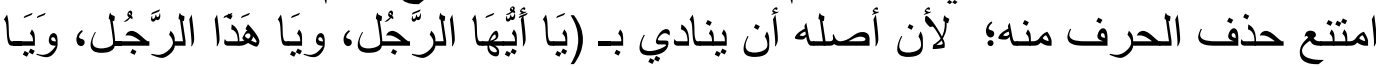

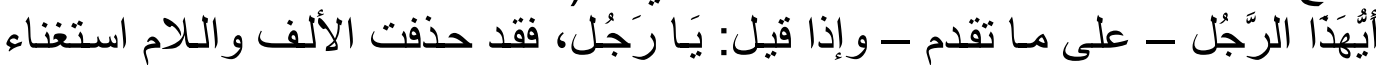

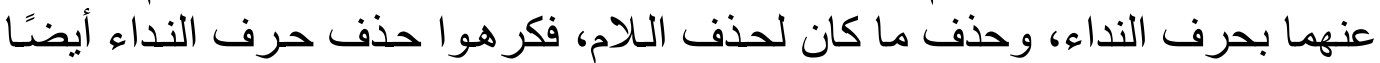

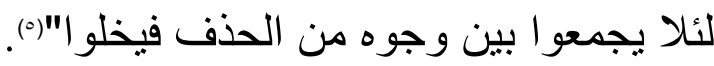

\section{• ع- اجتهماع التهريفين هكروه:}

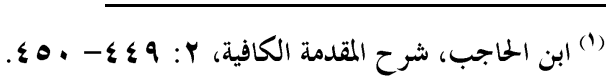

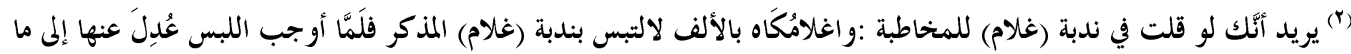

يجانس حركة الآخر وهو الياء ؛ لأن الكاف مكسورة.

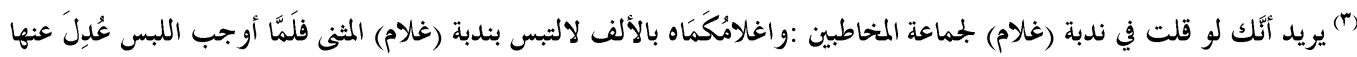

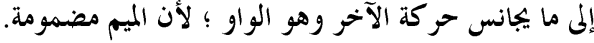

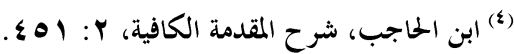

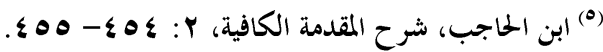




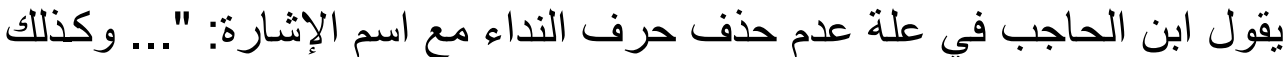

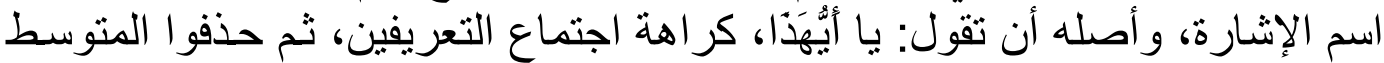

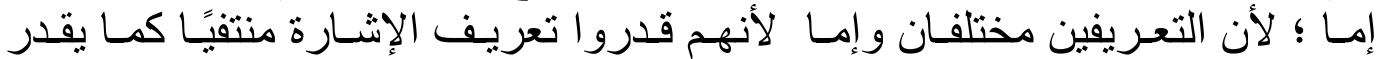
بعضهم انتفاء تعريف العلمية فبقي: يا هذا، فكر هوا الحذف خوف الإخلال" (').

\section{اء- لا يستقيه إعمال الفعل عمملين هن جهة واحدة:}

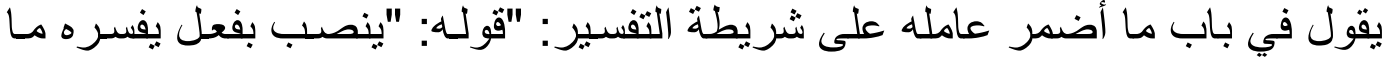

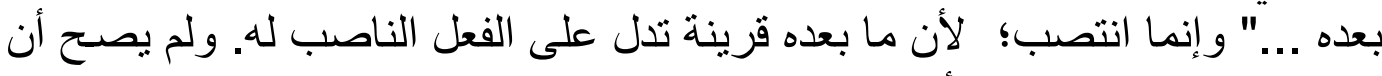

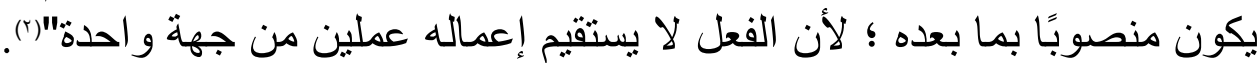

\section{rأ- ها لا يلزم معه تقدير ولا حذف أولى:}

يقول في باب ما أضمر عامله على شريطة التفسير: "قوله فئ: "ويختار الرفع بالابتداء

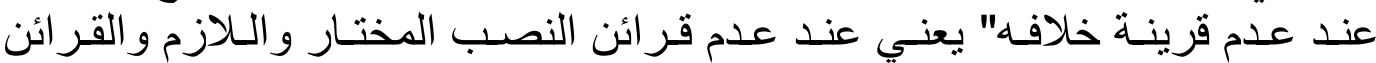

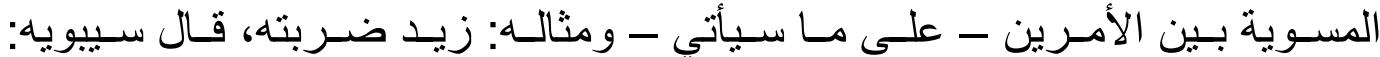

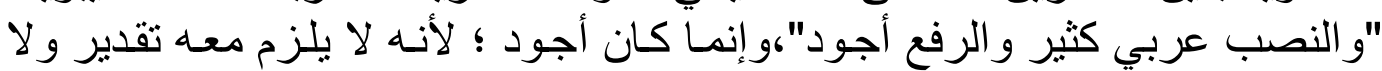

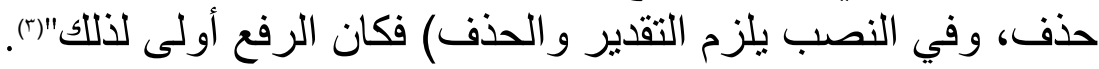

\section{بأ- الطلب لا يصلح خبرا لمناقضته له إلا بتأويل بعيد:}

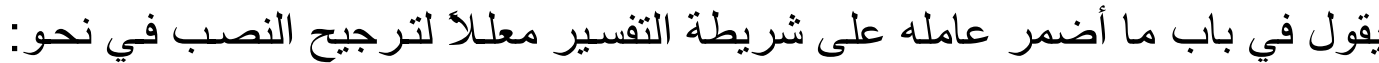

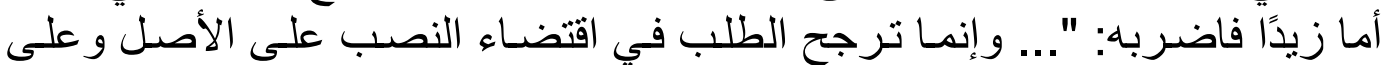

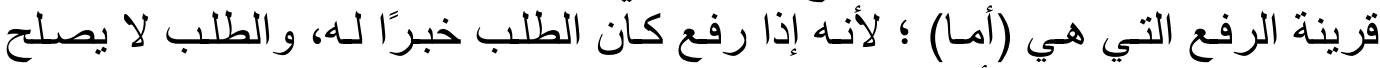

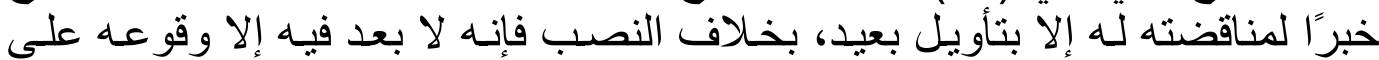

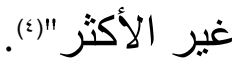

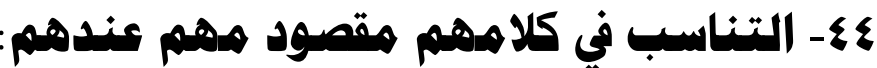

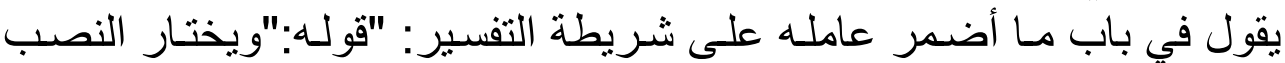

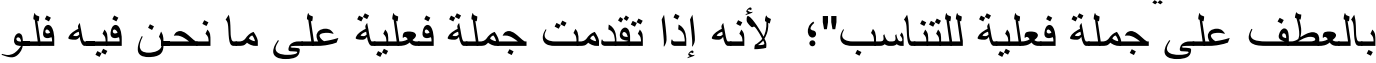

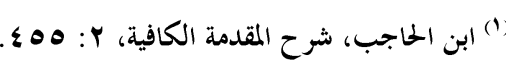

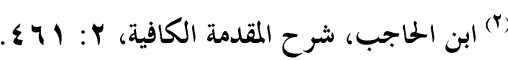

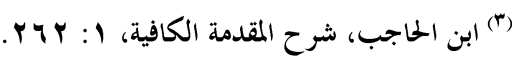

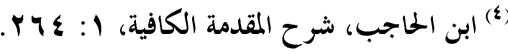


رفع لكان جملة اسمية، فيكون قد عطف جملـة اسمية على جملـة فعلية وهو غير متناسب، و التناسب في كلامهم مقصود مهر عندهم"'(').

\section{0 - لا يعمل الفعل رفها فيسما قبله:}

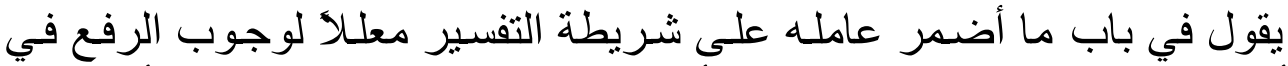

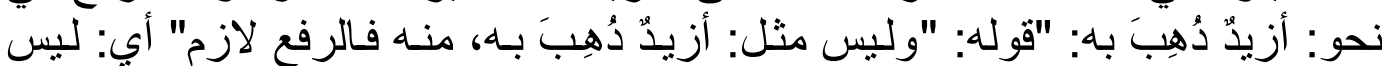

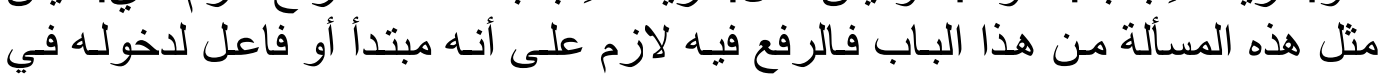

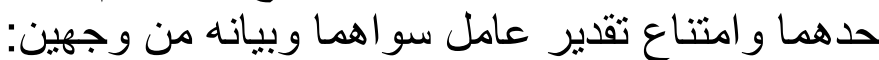

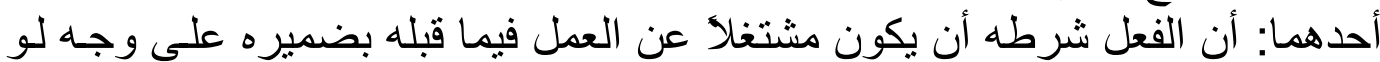

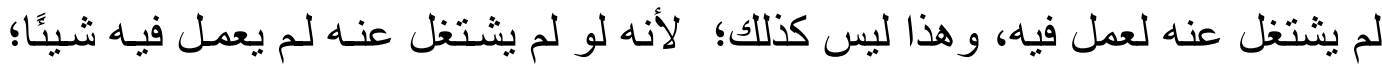

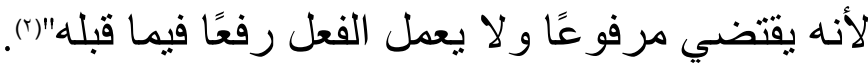

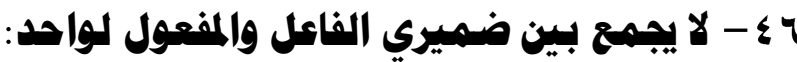

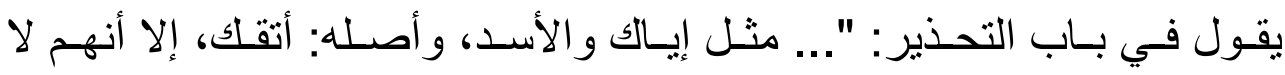

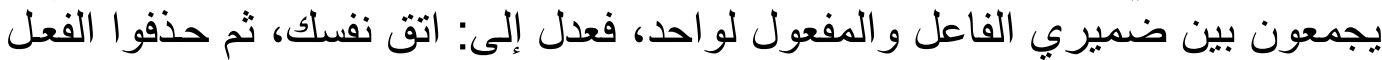

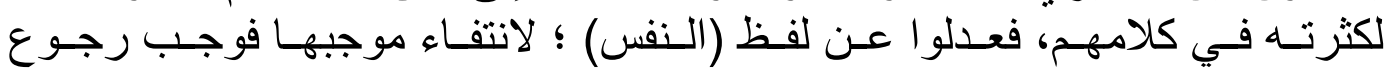

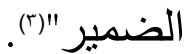

\section{S V - أصول الأبواب لا تثبت بالمتسملات:}

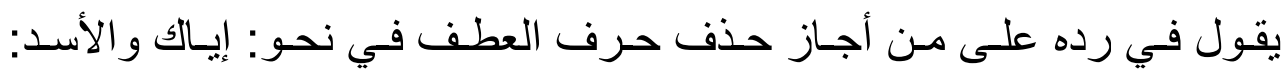

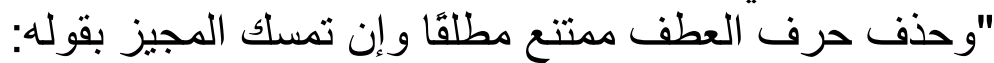

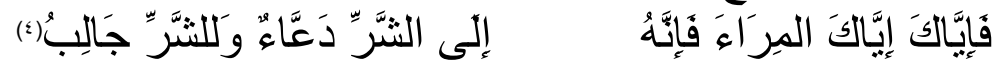

$$
\text { فليس فيه حجة لأمور منها: }
$$

الأول: أنـه على خـلاف القياس و استعمال الفصـاء ومثنل ذلك مـردود لا تثبت بـهـ الثاني: أنه في ضرورة الثعر، و الكلام في سعة الكلام.

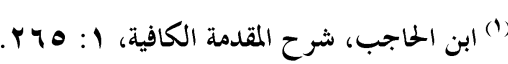

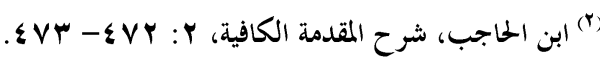

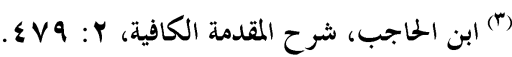

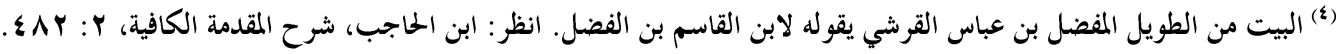


الثالث: أن المر اء مصدر بمعنى (أن تمـاري) فحمل عليه لكونـهـ بمعنـاه بخـلاف بـاب

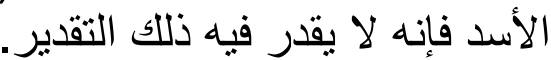
الر ابع: قول الخليل إن (المراء) منصوب بفعل مقدر ، و إئل إياك إياك) مستقل، ثم شرع في كلام آخر فقال: (المر اء). الماء). وإذا احتمل ذلك لم تبق فيه حجة؛ لأن أصول الأبو اب لا تثبت بالمحتملات"(').

\section{^ـ - ها جاز هـ هعنى الفعل فهو في صريح الفعل أجوز:}

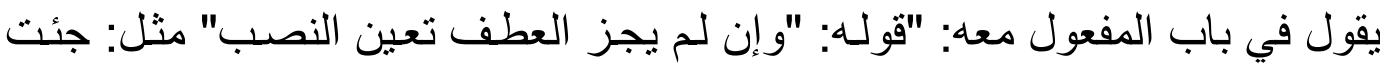

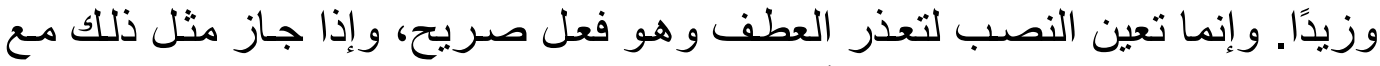

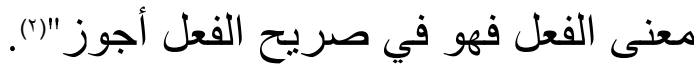

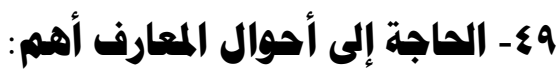

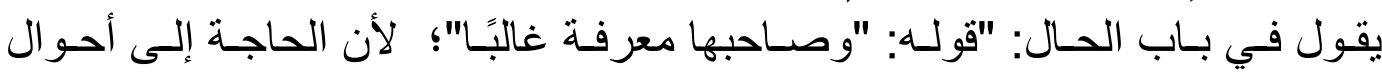
المعارف أهم، بخلاف النكرة فإن وصفها يغني" "(r).

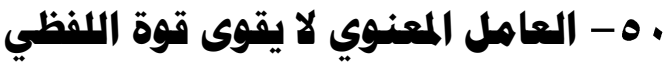

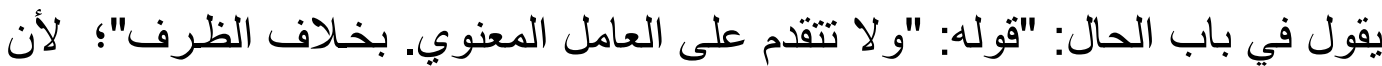

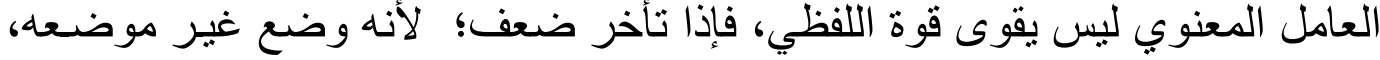
فقد يضعف العامل اللفظي بالتأخر فهذا أجدر" (().).

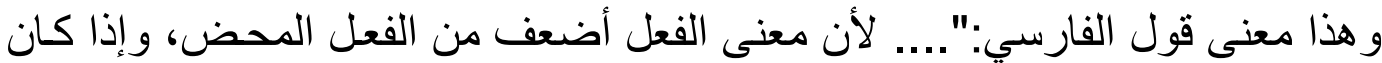

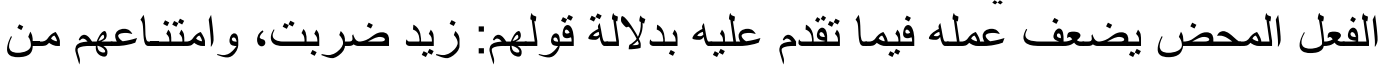

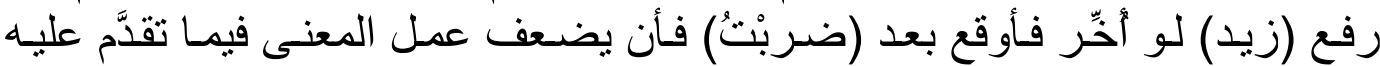

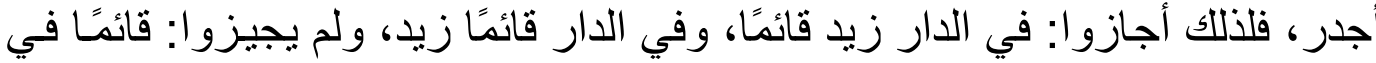

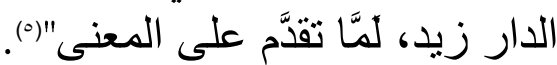

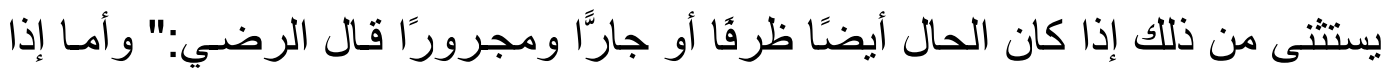

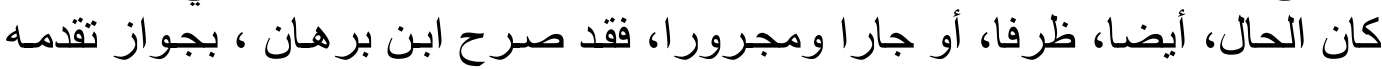

$$
\begin{aligned}
& \text { (1) ابن الحاجب، شرح المقدمة الكافية، ب: سمی؛. }
\end{aligned}
$$

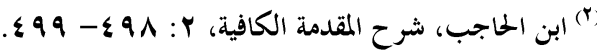

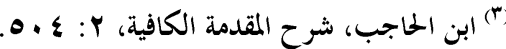

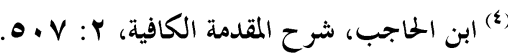

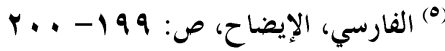


على عامله الذي هو ظرف أو جار ومجرور، وذذلك لتوسعهم في الظروف، حتى جاز

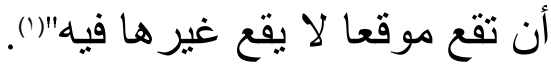

اهـ إنضيل الشيء على نفسه لا يعقل إلا باعتبارين:

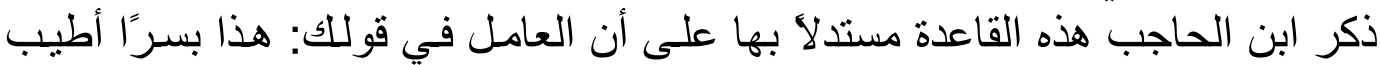
منه تمرًا (أطيب) حيث عملت في الحالين بسرًا وتمرًا (). .

\section{or - or إذا اهتنع تقديم الأصل فاهتناع تقديم الفرع أجدر:}

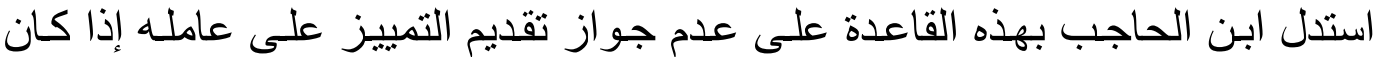

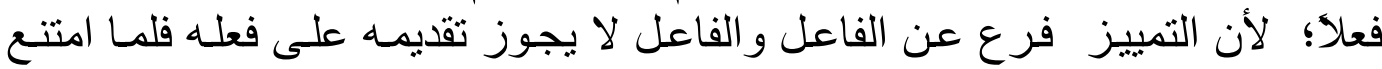

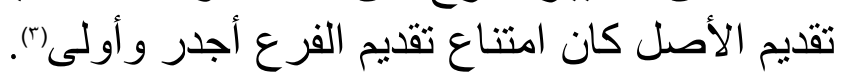

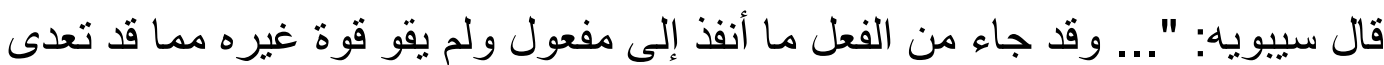

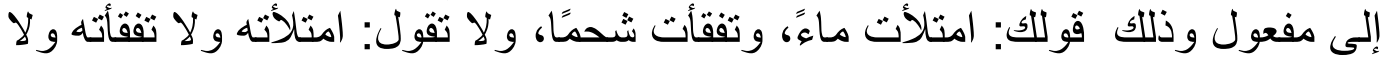

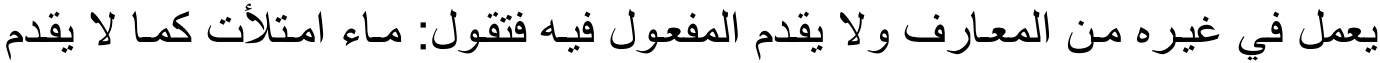

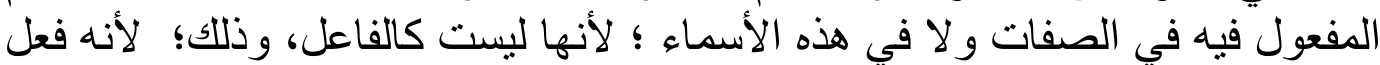
لا يتعدى إلى مفعول و إنما هو بمنزلة الأفعال و إنما أصله امتلأت من ماء وتهاء وتفقأت من فن

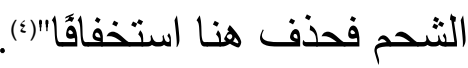

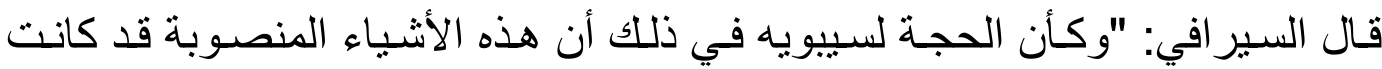

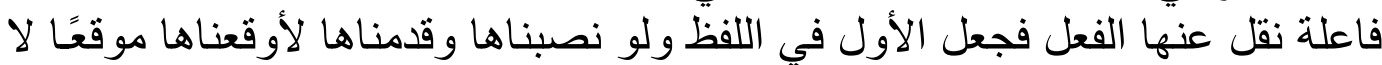

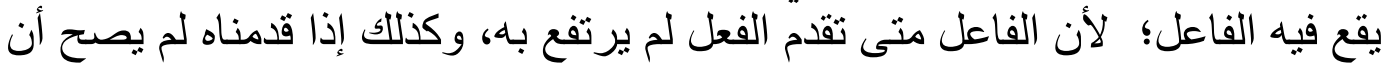

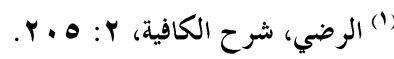

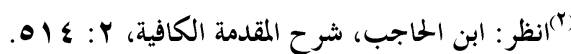

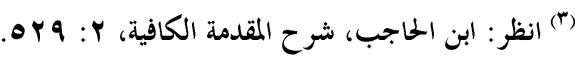

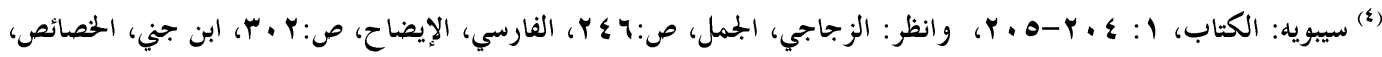

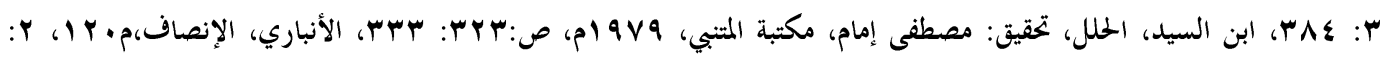

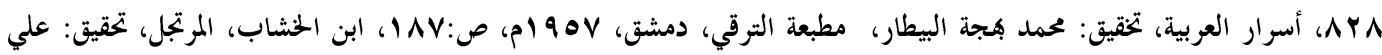

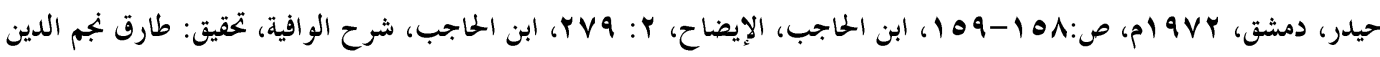

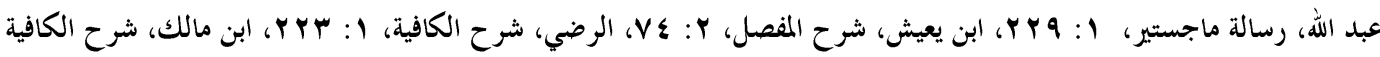

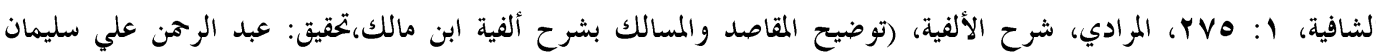

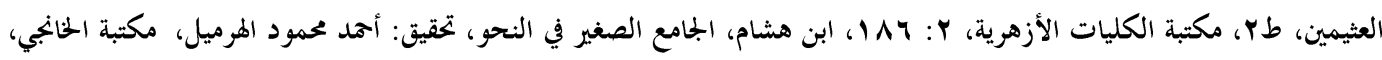

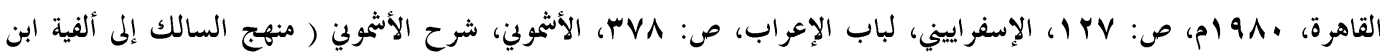

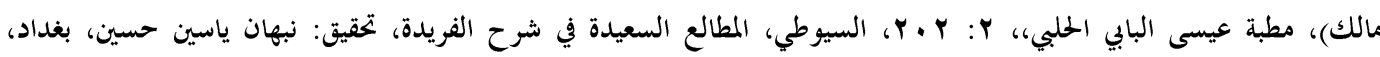




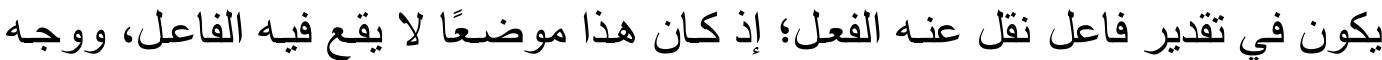

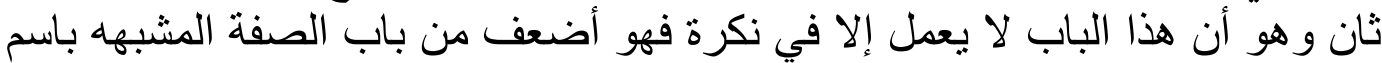
الفاعل فلما كانت الصفة المشبهة باسم الفاعل لا يجوز تقديم ما عملت فيه عليهـا كـان هذا أحرى بالامتناع من ذلك "(') وبهذا تكـون هذه القاعدة سـبق إليهـا سـيبويه معنـئ وصـاغها ابـن الحاجب صـياغة منطقية.

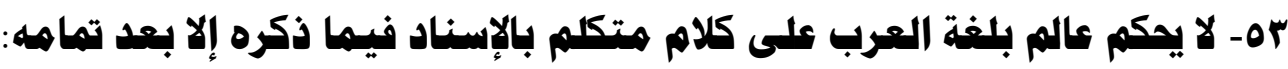

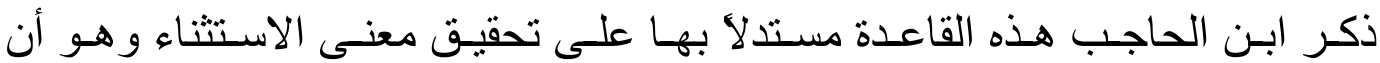

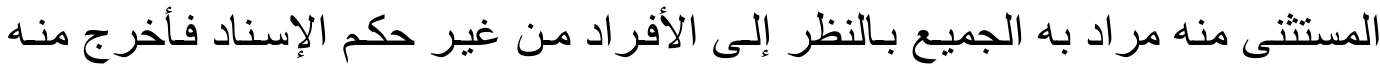
المستثنى على التحقيق ثم حكم بالإسناد بعد تقدير الإخراج ومذا المعنى هوالمستّيم المندفع عند الإشكالات الأخرىفي القولين الآخرين في تحقيق معنى الاستثناء، وهذان القولان الآخران في تحقيق معـنى الاستثناء هما:

ا ـ الاستثناء مبين لغرض المتكلم بالمستثنى منه فهو مثل التخصيص عند هؤلاء في

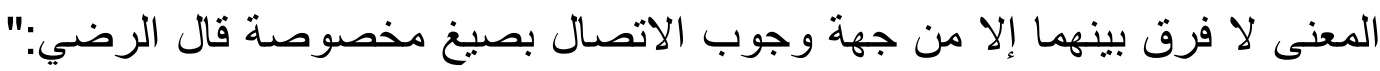

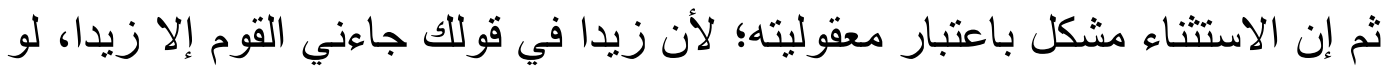
قلنا انه غير داخل في القوم، فهو خلاف الإجماع؛ لأنهم أطبقوا على أن الاستثناء

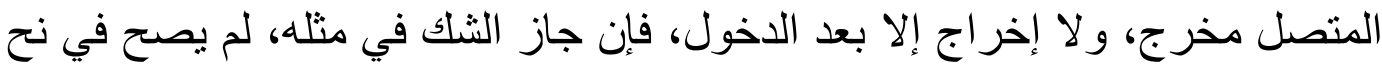

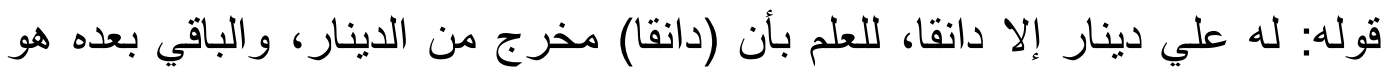

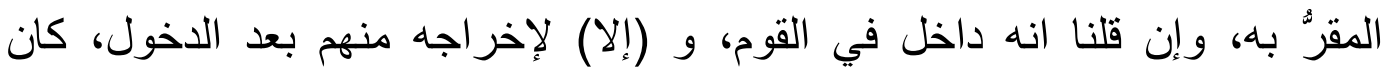
المعنى: جاء زيد مع القوم، ولم يجئ زيد، وهذا نتاقض ظاهر ينبخي أن يجنب كلام ولام

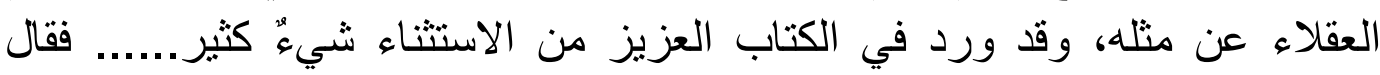

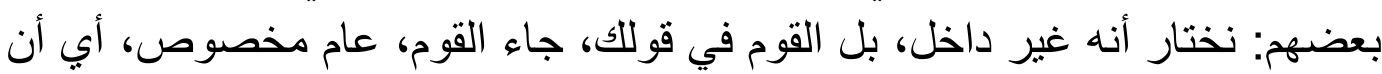

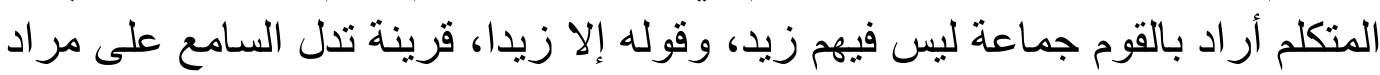
المتكلم، وانه أر اد بالقوم غير زيد، وليس بشيءِ، لاجتماع أهل اللغة على أنى أن الاستناء

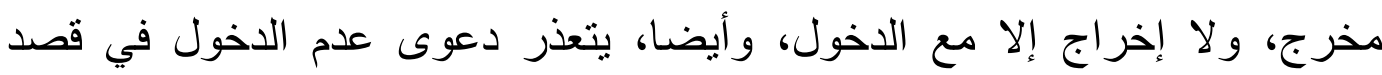


المتكلم في نحو: له علي عشرة إلا واحدا؛ لأن (واحدا) داخل في العشرة بقصده، ثم

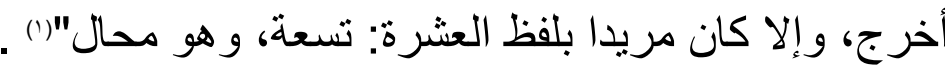

\section{§ه- ها قَلَّ تقديره وقوي هعناه فهو أولى:}

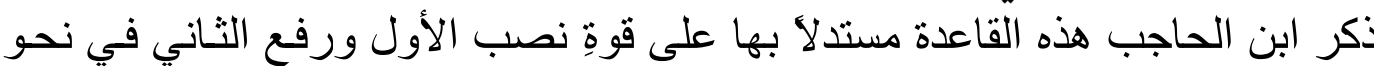

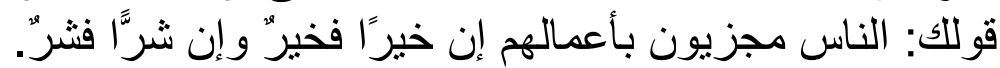
يجوز في هذه المسألة أربعة أوجه:

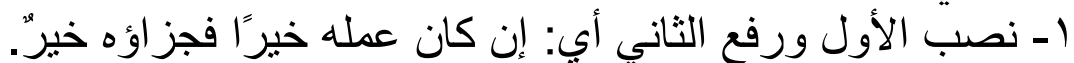

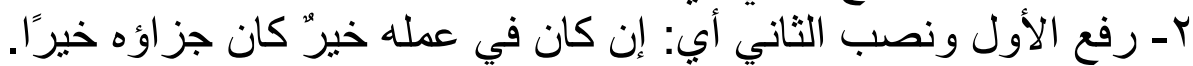

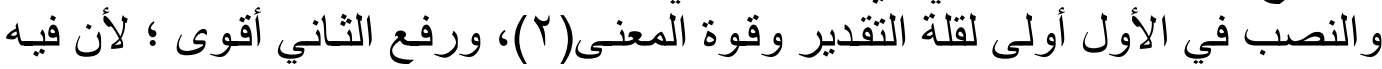
إضمار المبتدأ بعد فاء الجزاء أل ال غير وهو كثثير (r).

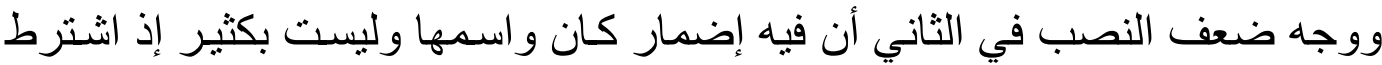

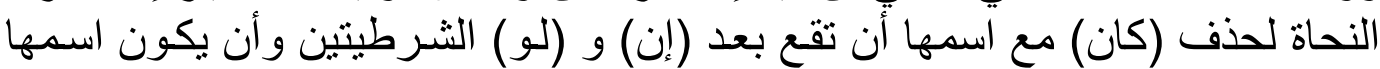

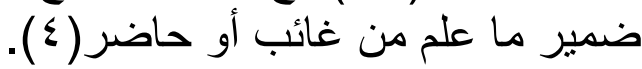

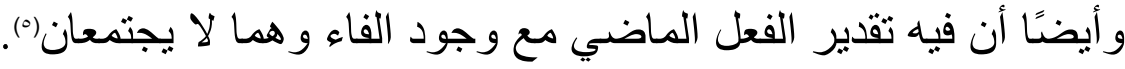

ذهـ لا يلزم هن القصد إلى هناسبة ألفاظ هتعددة هناسبة ألفاظ أقل هنها:

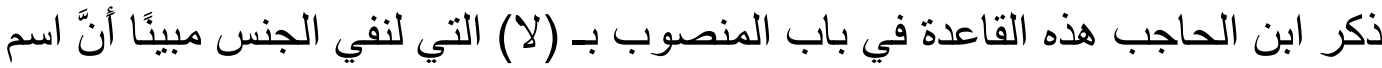

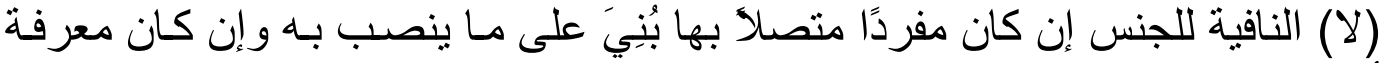

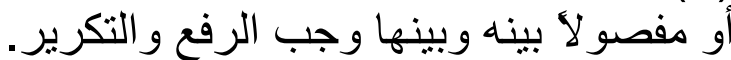

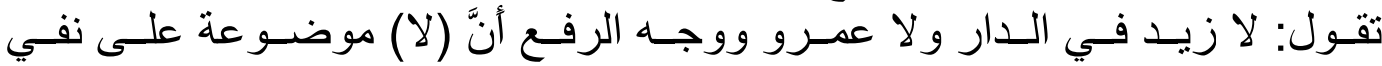

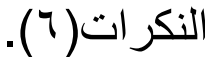

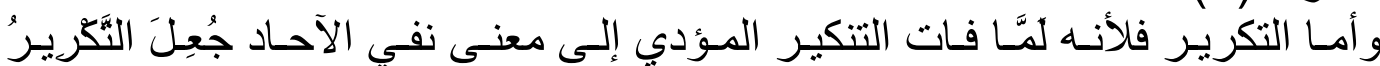

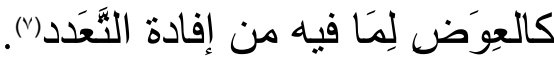

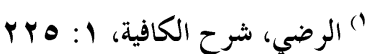

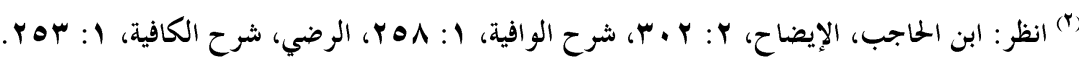

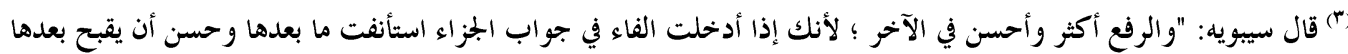

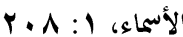

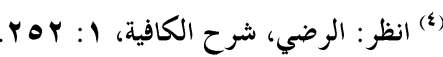

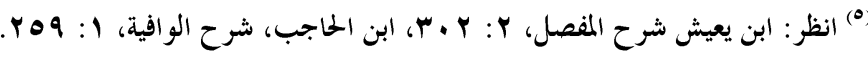

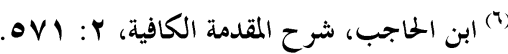

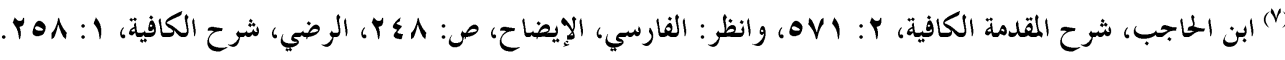




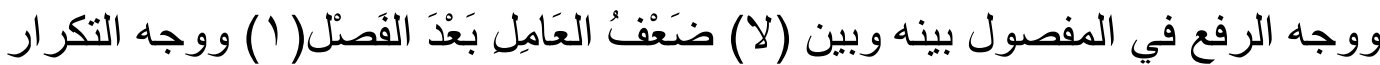

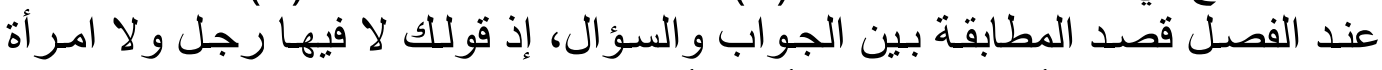

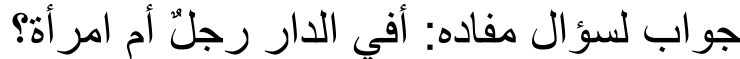

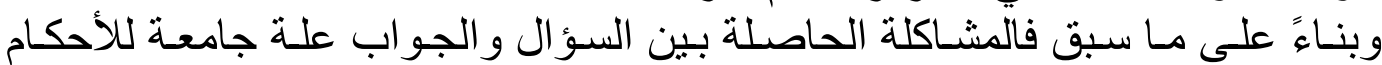
الثثلاثة: الرفع و الفصل و التكر ار (").

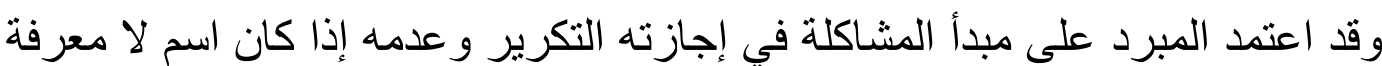

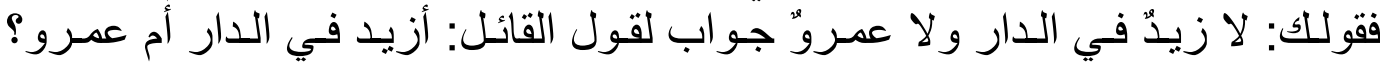

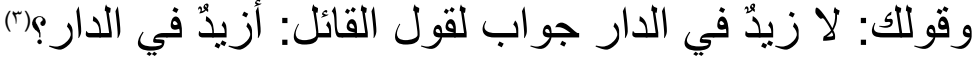
وسكت عن حكم التكرير إذا كان اسم (لا) مفصو لا بينه وبينها بل إنه لا لا برى في اسم الحم

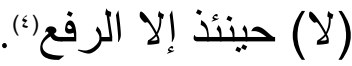
أما ابن الحاجب فيرى التكرير عند الفصل بين (لا) واسمها استنادًا إلى مبدأ المشاكلة ولا يرى عدم التكرير عند الفصل استنادًا إلى مبدأ المشاكلة. يقول: "فإن قيل فمقتضى ذلك أن يجوزو ا: لا فيها رجلّ، جوابَّا لمن قـال: أفي الدار

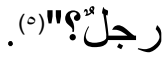
أجاب عن هذا الاعتر اض بجو ابين:

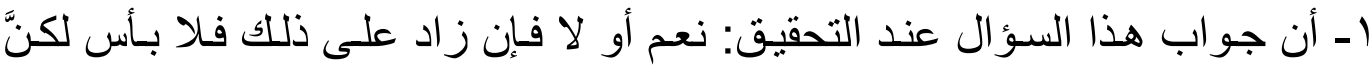

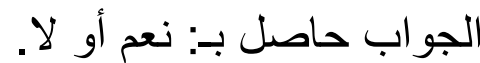
r- أنه لا يلزم من القصد إلى مناسبة ألفاظ متعددة مناسبة ألفاظ أقل منها (7).

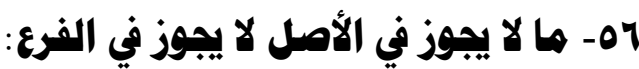

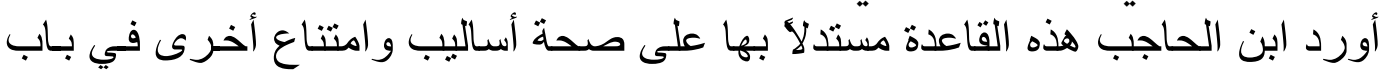

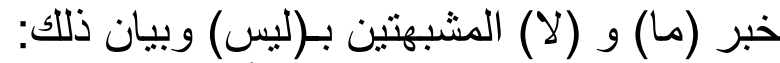

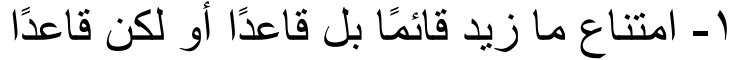

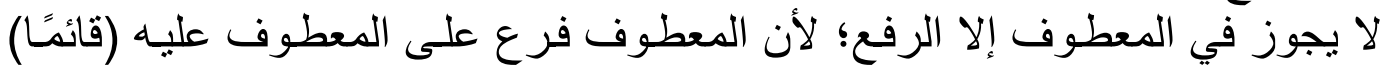

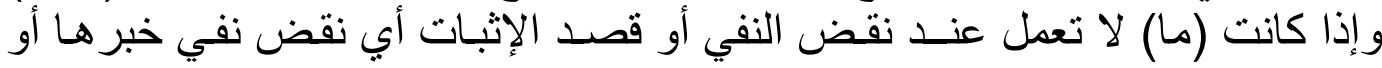

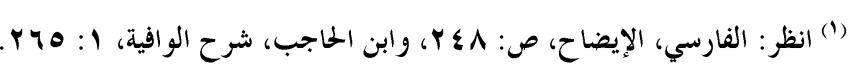

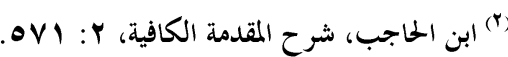

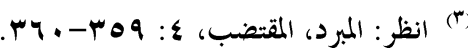

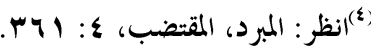

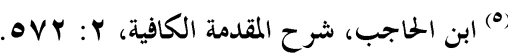

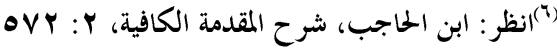


قصد إثبــاته وكان هذا مبطلا لعملها في الأصل (المعطوف عليه) فهو في (الفرع)

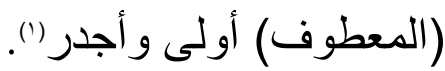

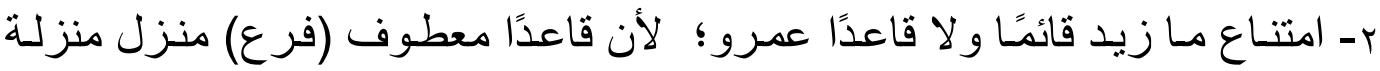

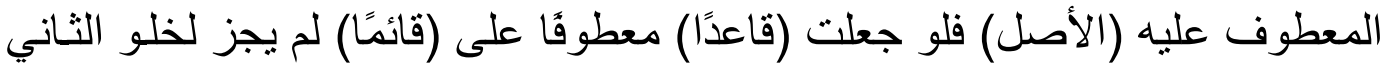

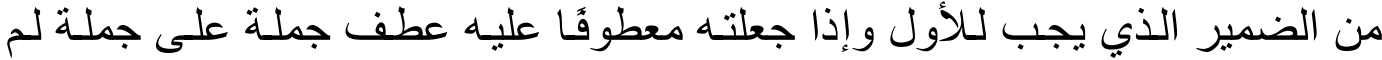

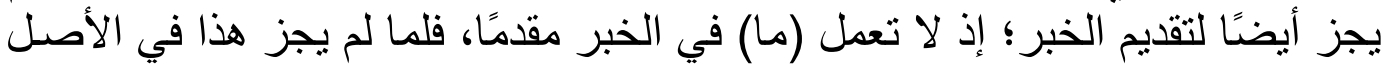

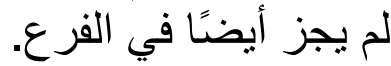
r- صحة ليس زيد قائمًا و لا قاعدًا عمرو إذا جعلت العطف من قبيل عطف الجمل إذ إذ

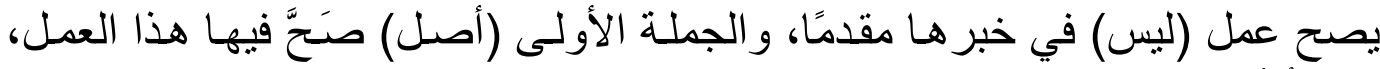

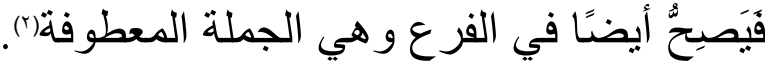

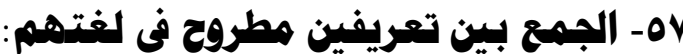

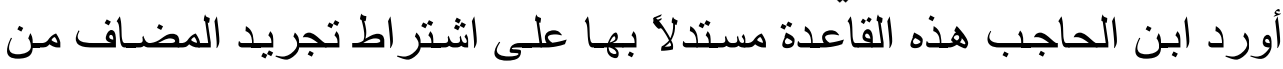

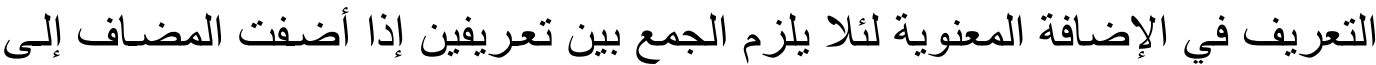

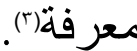

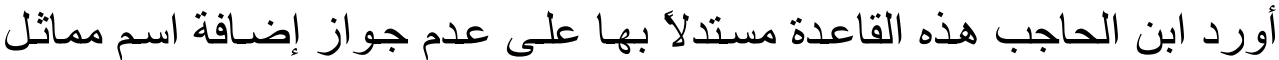

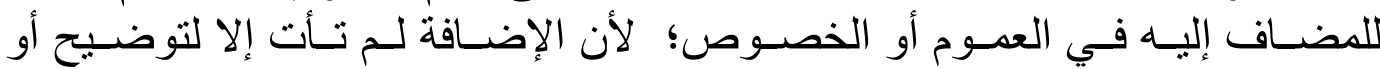

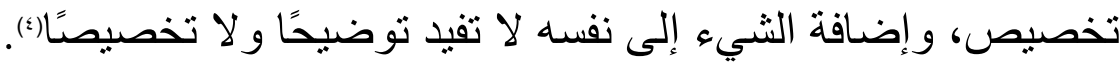

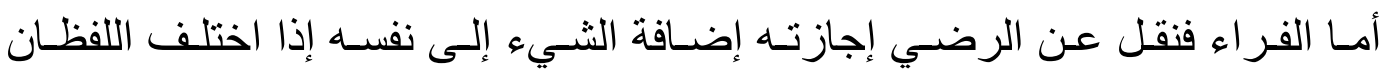
للتخفيف، وبهذا خرج الفر اءء عن هذه القاعدة مخالقًا لهاء(اء).

\section{هـ - الإضافة إلى الأوضح أولى هن العكس :}

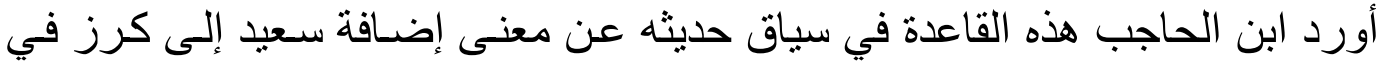

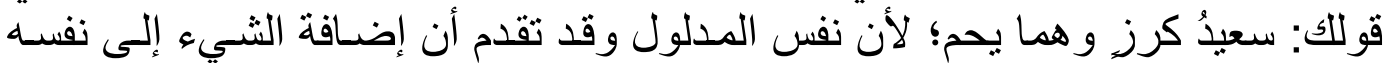

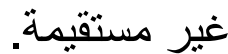

$$
\begin{aligned}
& \text { (1) انظر: ابن الحاجب، شرح المقدمة الكافية، ب: ه人ه. }
\end{aligned}
$$

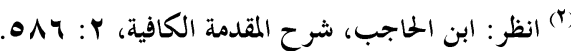

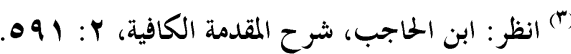

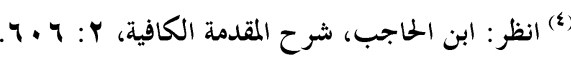

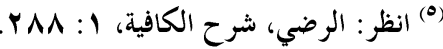




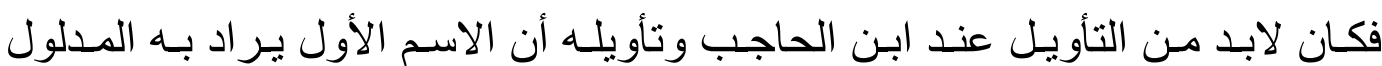

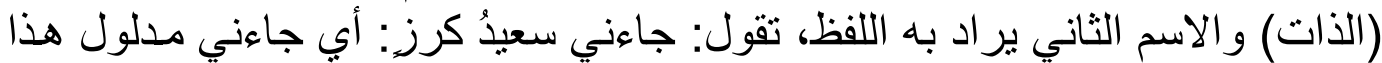

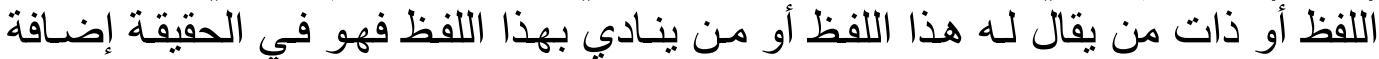

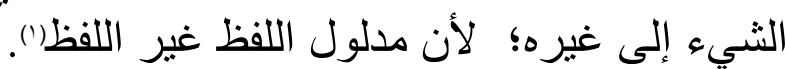

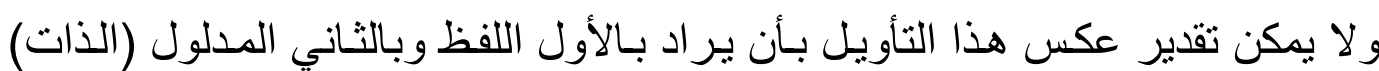

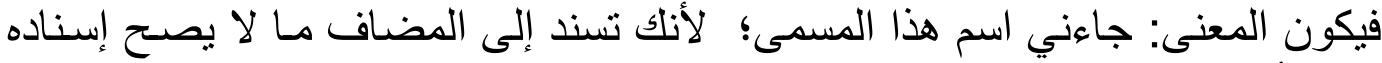

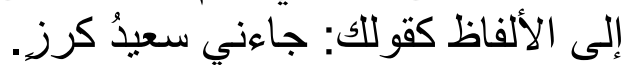

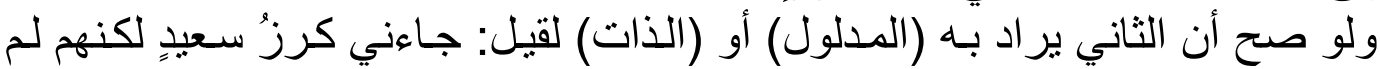

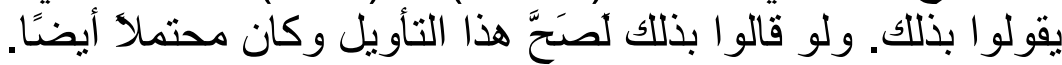

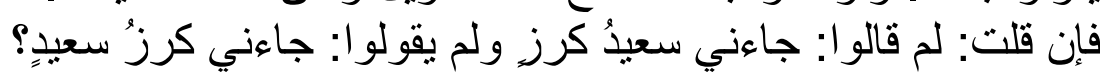

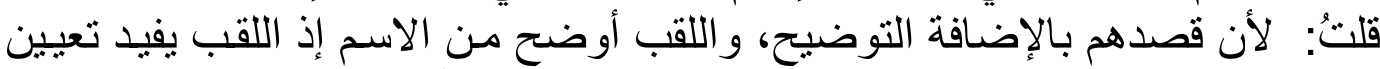

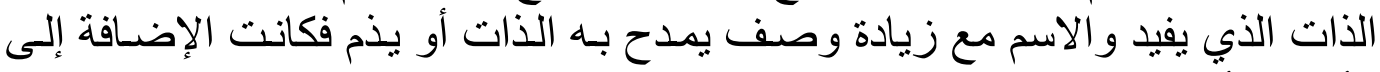

$$
\text { الأوضح أولى من العكس(ب). }
$$

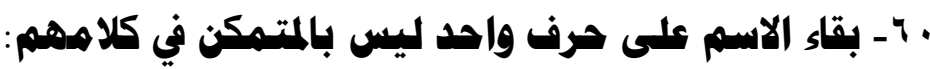

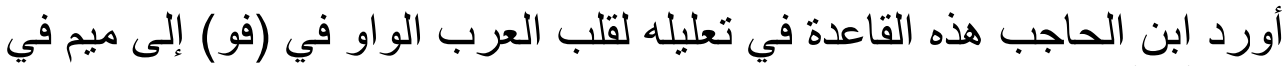

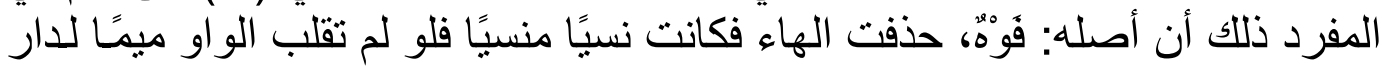

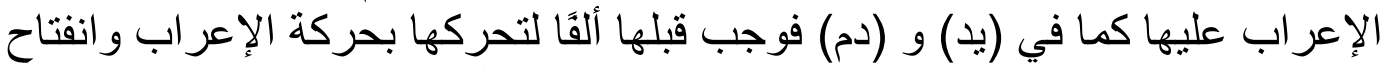

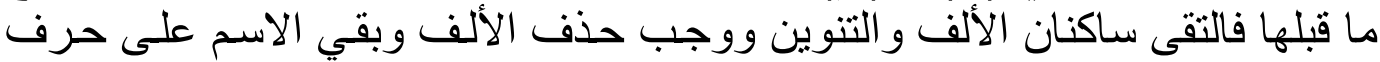

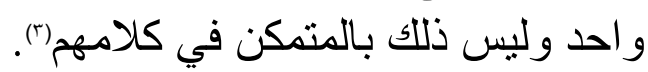

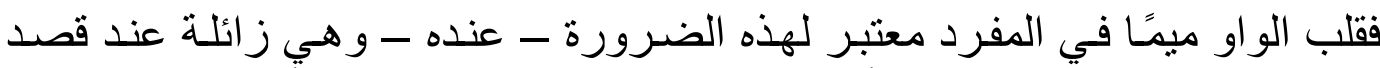

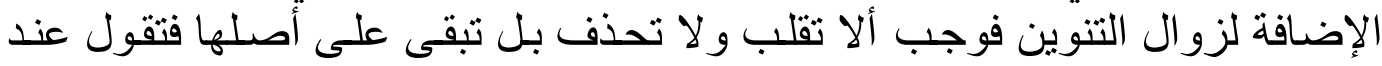

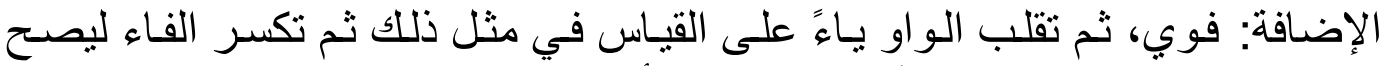

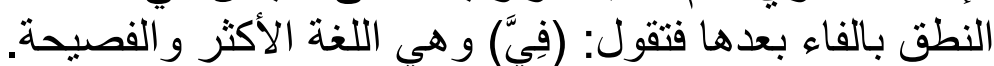

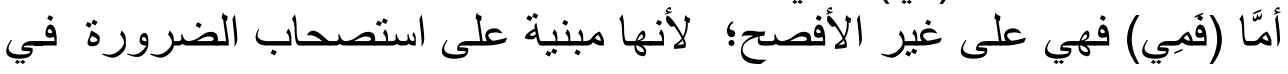
حال الإفر اد و هذا ليس بمستقيم عند ابن الحاجب)(").

\section{آ- اتصال المضهر الجبرور بالجار أشد هن اتصال الفاعل بالفعل:}

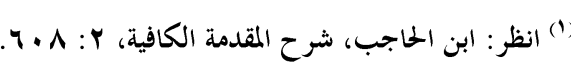

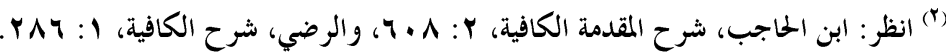

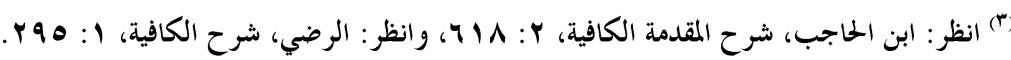

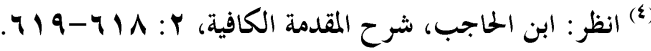




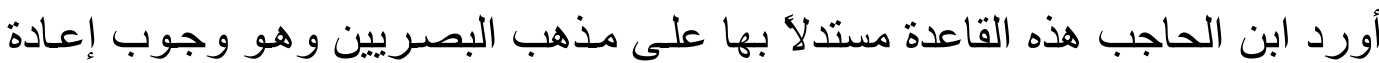

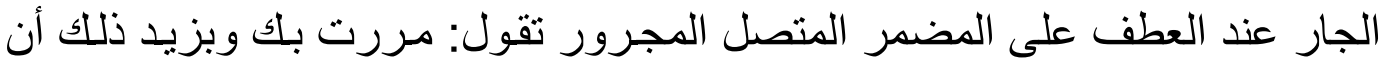

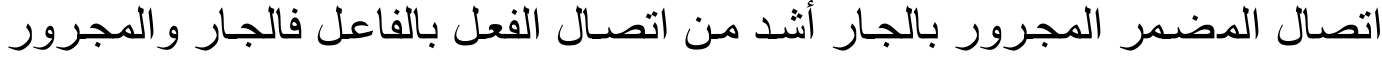

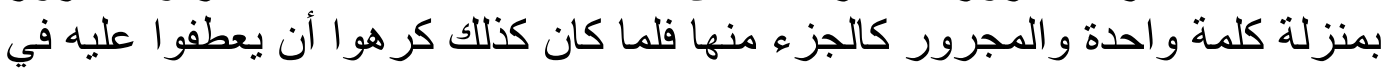

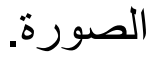

وَكمَّا كان الضمير المتصل المرفوع كالجزء من الكلمة الو احدة إذ الفعل و الفاعل

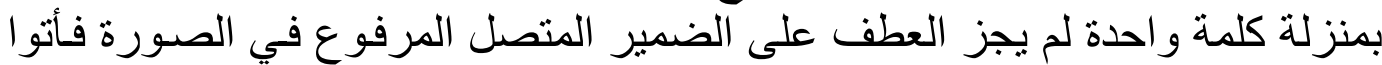

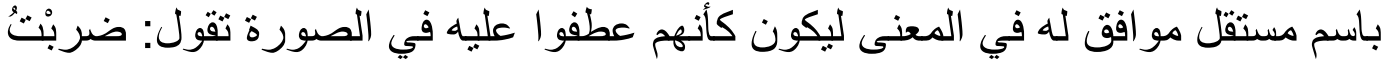

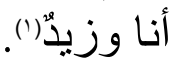

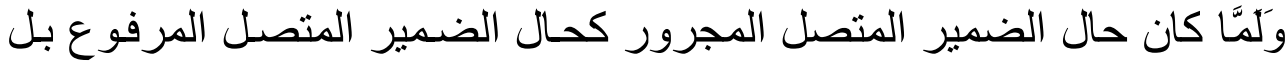

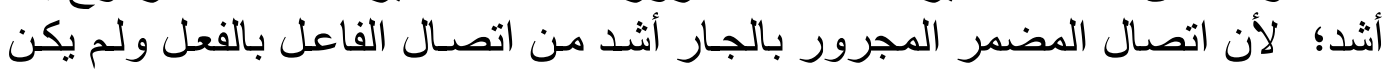

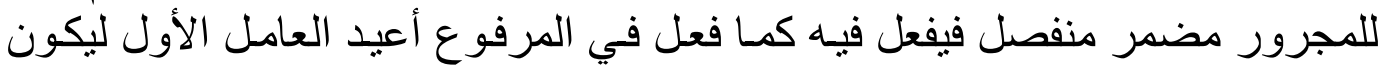

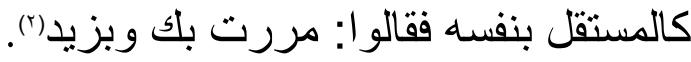

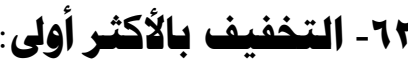

أورد ابن الحاجب هذه القاعدة معتلا بها لاستتار الضمير المرفوع المتصل في

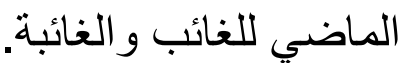

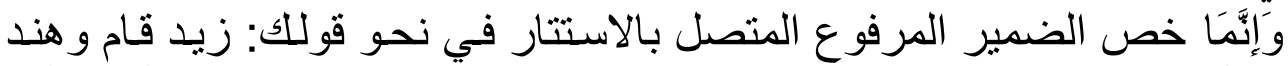

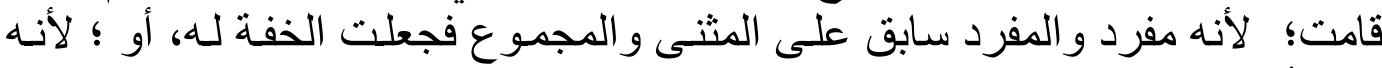
يكثر أكثر من غيره فجعلت الخفة لهن له.

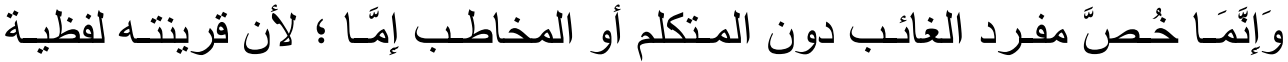

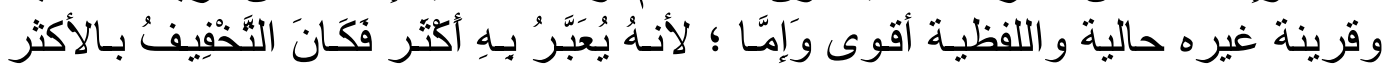

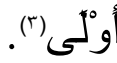

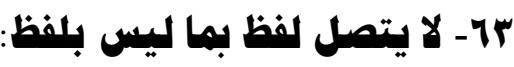

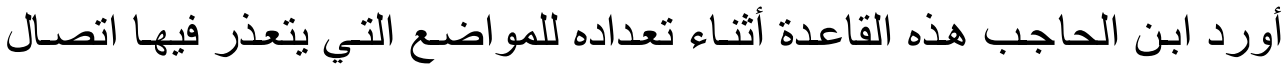

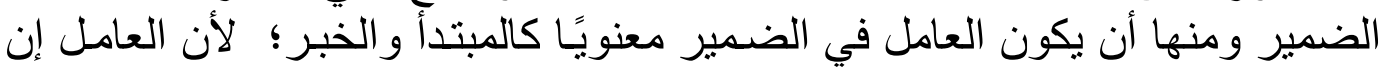

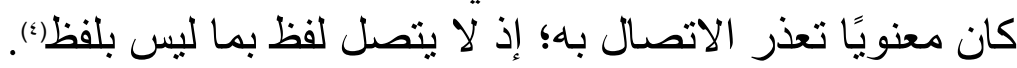

§ 1 - وضع العرب على أن تكون القرينة في نفس اللفظ لا خارجة عنه:

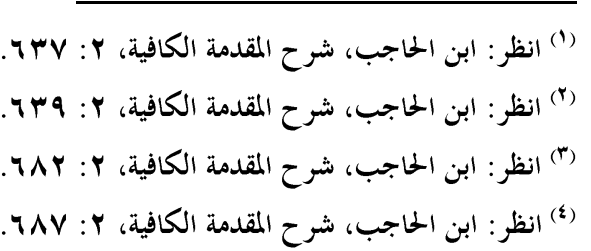




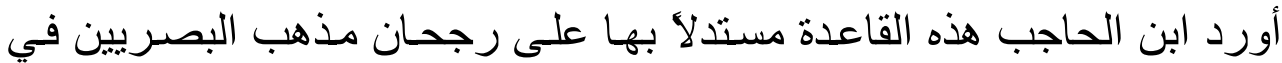

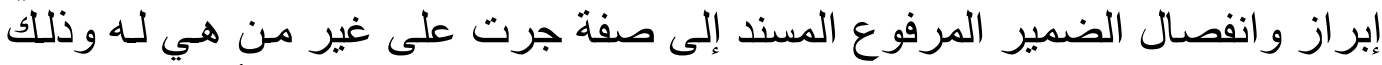
في نحو قوللك: هند زيد ضاربته هي، وزيد هند ضاربها لإن هو، وذللك ؛ لأن الضمير هنا لو كان منصلا بالاسم لأدى إلى اللبس هئل

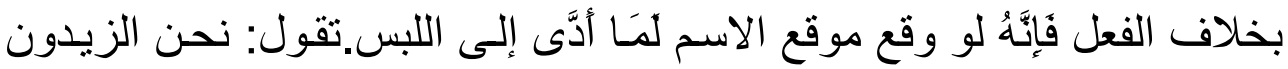

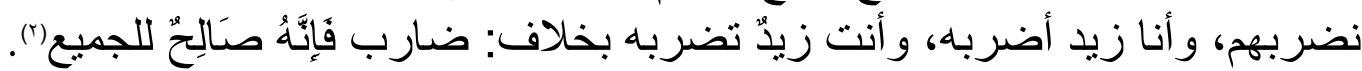

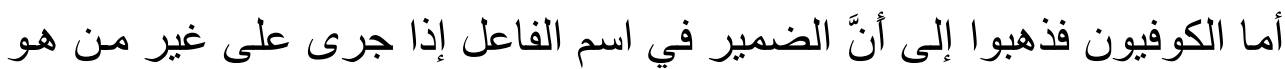

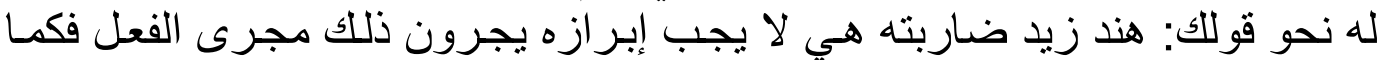

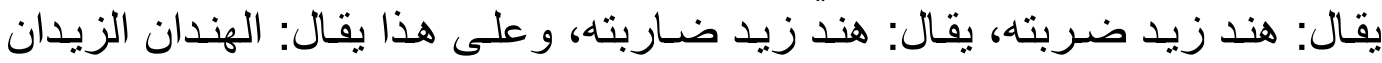

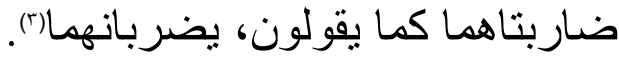

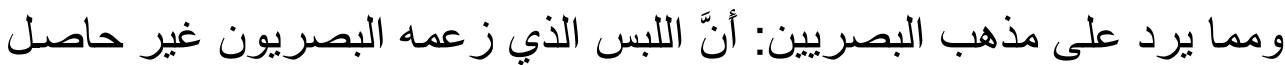

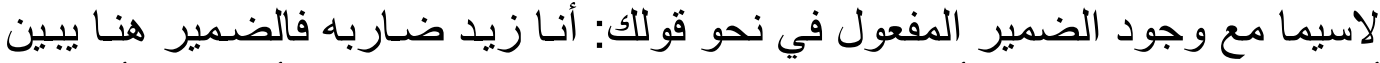

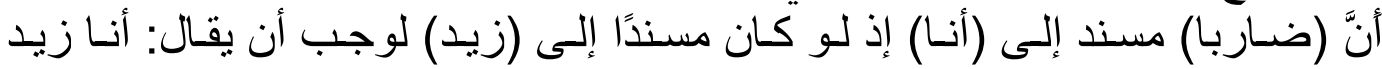

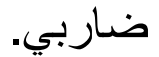

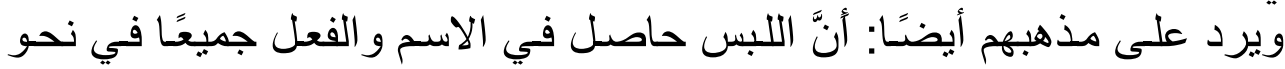

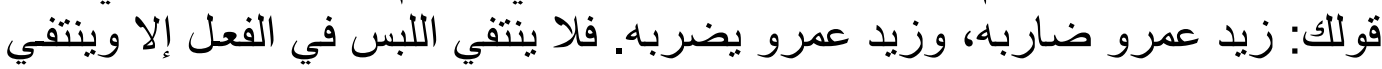

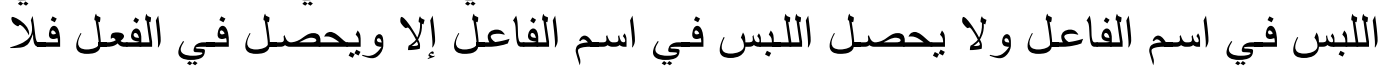

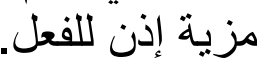
استخدم ابن الحاجب هذه القاعدة في الرد على هذين الاعتر اضين على مذهب

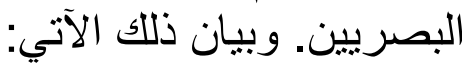

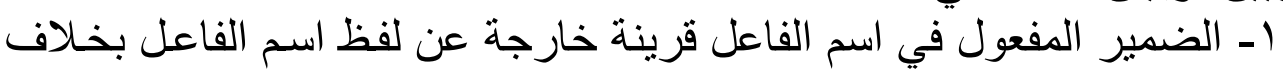

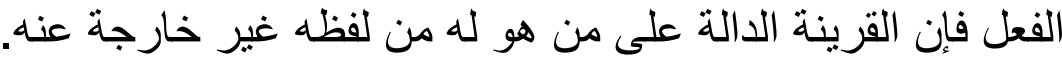

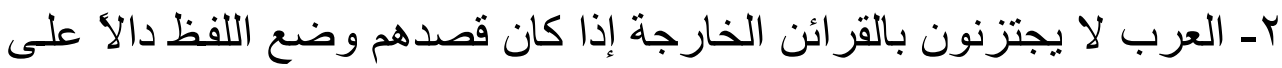

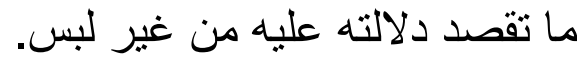

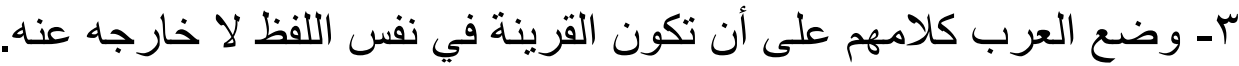

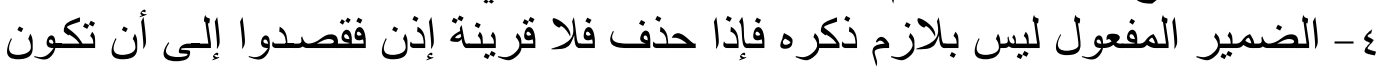
القرينة لازمة في نفس الكلمة حتى لا يقع اللبس عند الحذفي().

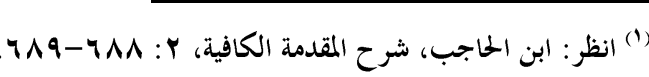

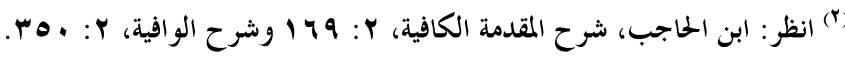

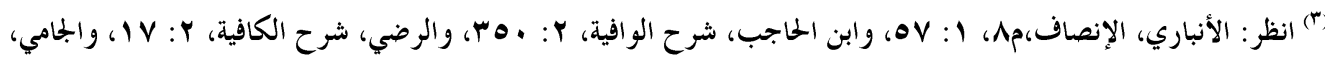

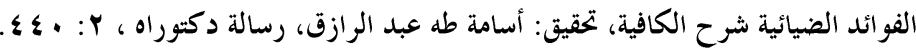

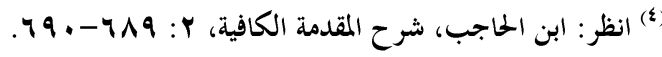




\section{0- دلالة المبتدأ على المبتدأ أولى ودلالة الفعل على الفعل أولى:}

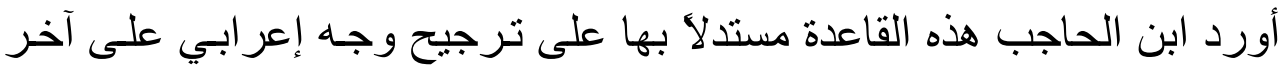
في نحو قولك: ماذا صنعت؟.

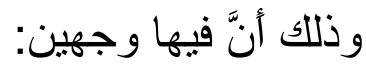

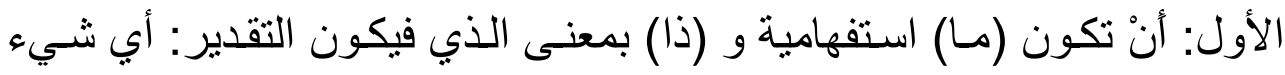

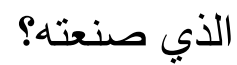

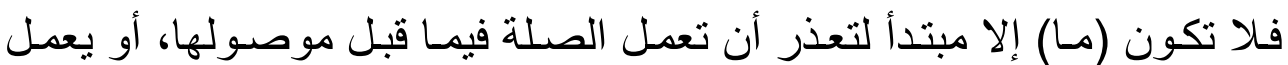

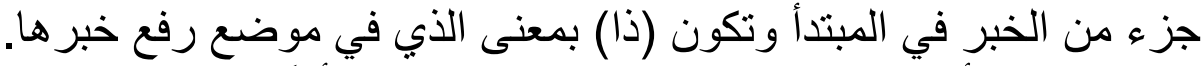

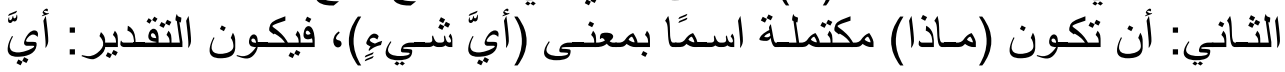

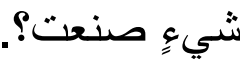

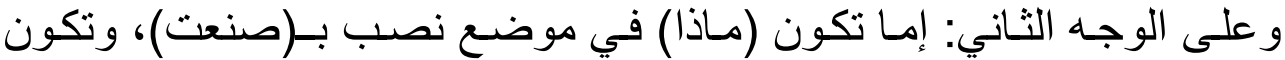

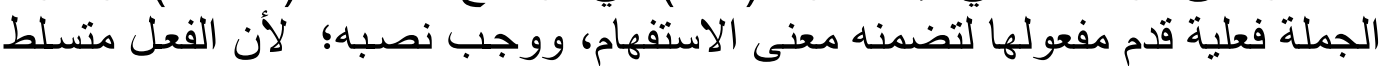
عليه تسلط المفعولية.

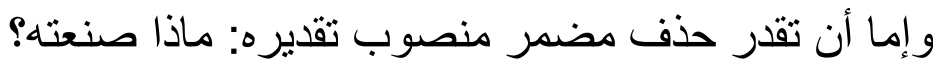

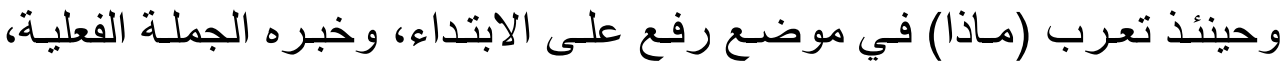
و العائد عليه الضمير المقدر . و والاختيار على الوجه الأول الرفع و على الوجه الثناني النصب.

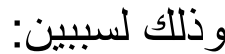

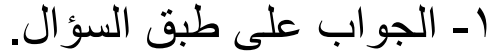

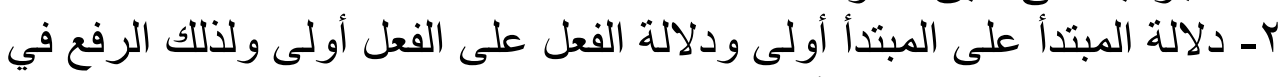

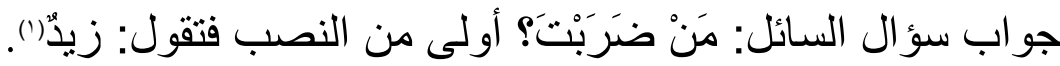

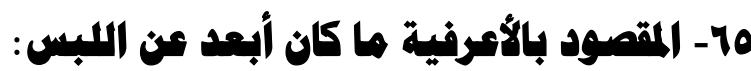

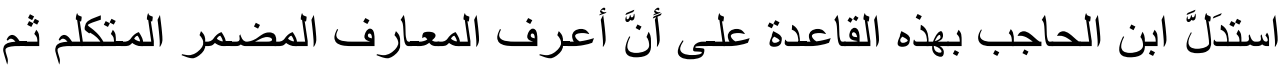

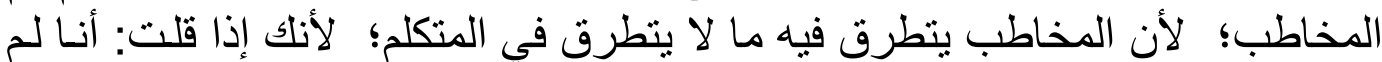

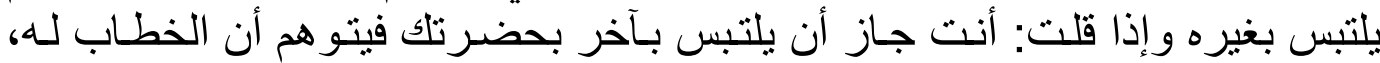

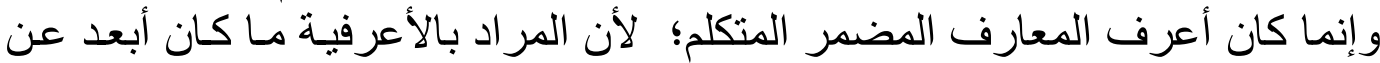

\section{7- توالي أربع نتحات في كلمة واحدة همع الاهتزاج بها فيه فتحة هكروه:}

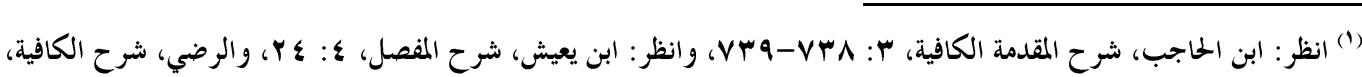

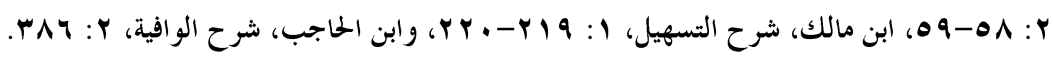

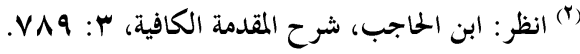


ذكر ابن الحاجب هذه القاعدة مبررًا كسر تميم لشين عشرة في نحو: ثـلاث

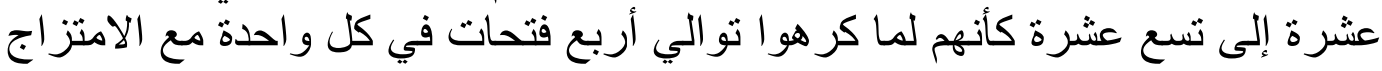

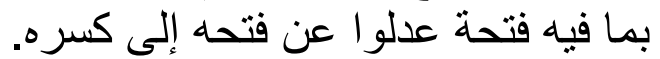

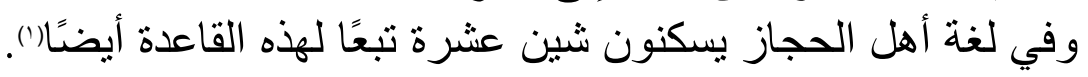

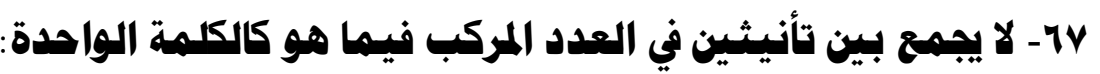
ذكر ابن الحاجب هذه القاعدة في سباق التعليل لـ:

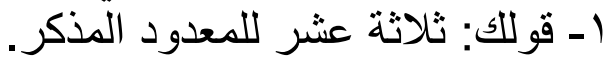

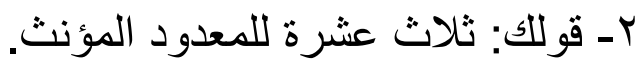

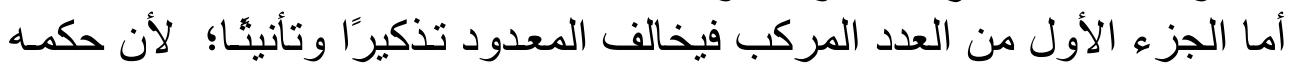
كان كذللك قبل التركيب فروعي بعد التركيب كذلك.

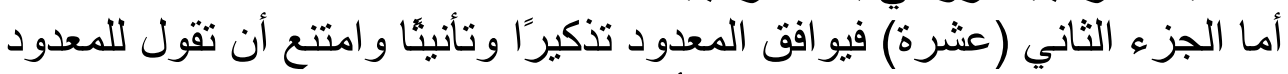

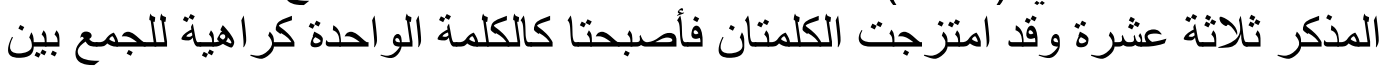
تأنيثين فيما هو كالكلمة الو احدة) (†).

\section{4- الأسسماك المشتركة لا تثنى باعتبار ها اشتركت فيه وإنها تثنى باعتبار كل واحد هـن}

\section{مدلولاتها:}

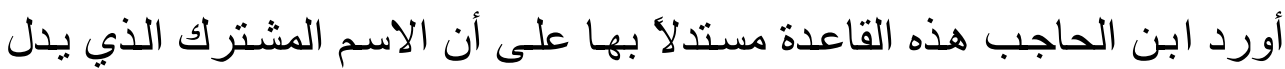

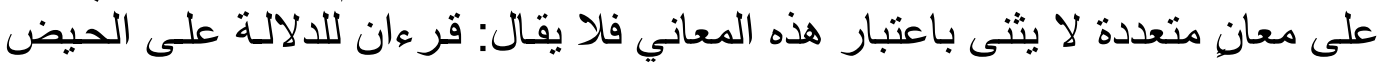

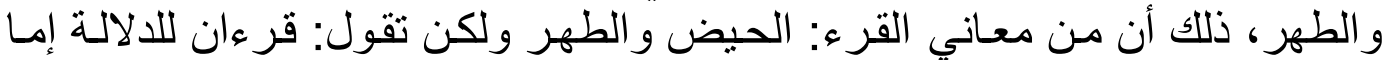

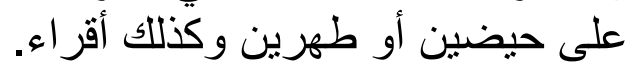

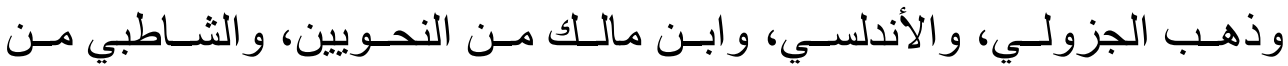

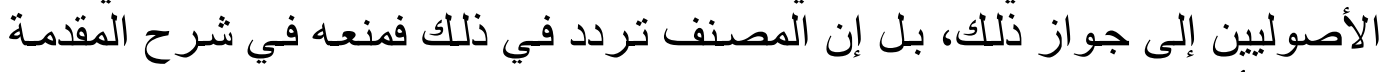

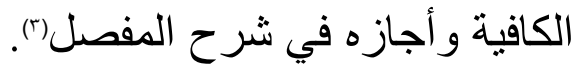

\section{9- الأصل للأصل والفرع للفرع:}

استدلَّ ابن الحاجب بهذه القاعدة على تحريك حرف المَف المضـار عة في أول الفعل الرباعي بالضم وتحريكه في أول مضدار إند الفعل الثناثي بالفتح.

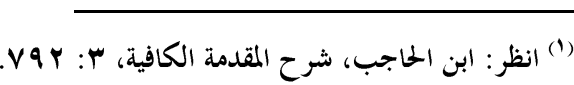

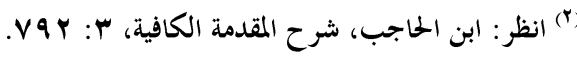

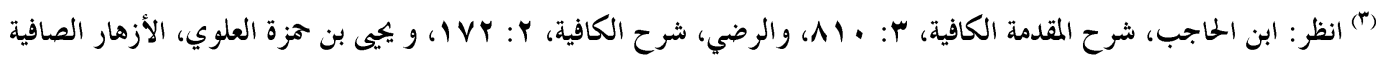

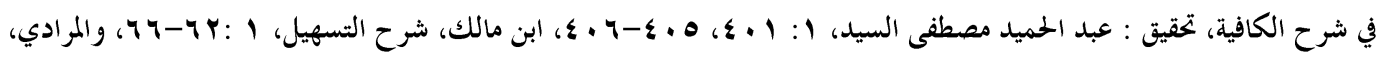

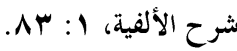


ذللك أن الثلاثي أصل فحرك حرف المضـار عة في المضـار ع منهـه بـالفتح الذي هو أصل الحركات وأخفها. و الرباعي فرع فحُرِّكَ حرف المضار عة في المضارع منه بالضم الذي هو فرع

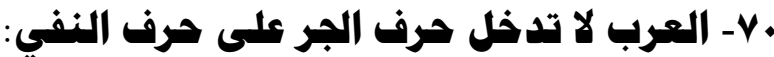

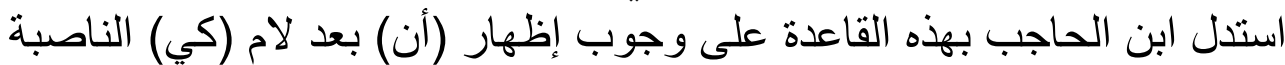
إذا كان معها (لا) النافية، تقول: أذاكر دروسي لئلا أرسب، وصالحت الحت أخي لئلا تتهار

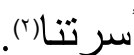

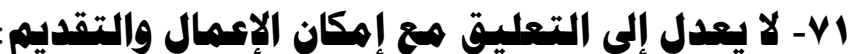

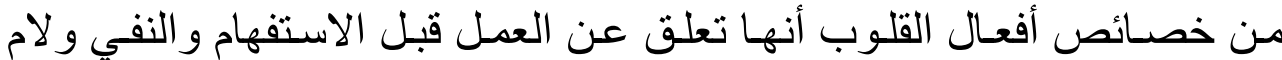

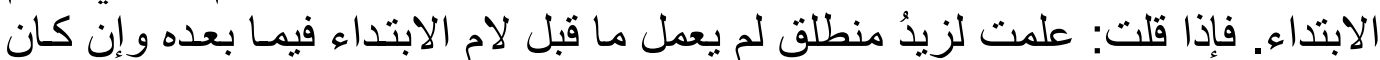
المعنى: علمت زيدًا منطلقًا.

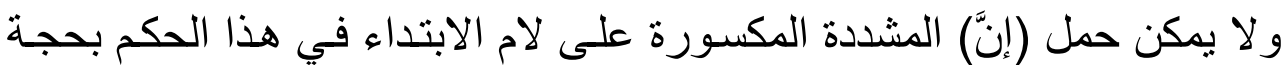

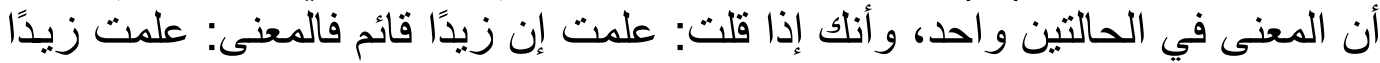

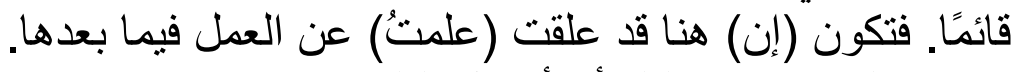

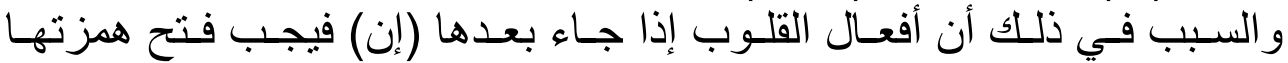

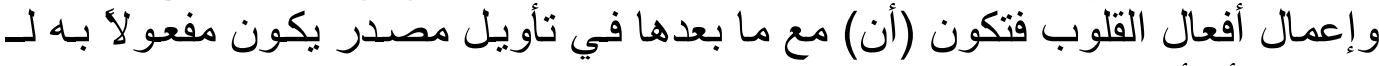

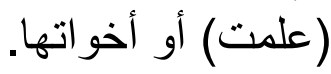
و عليه فلا يعدل إلى القول بالتعليق مع إمكان الإعمال و التقديم(").

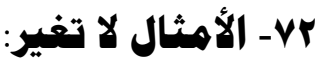

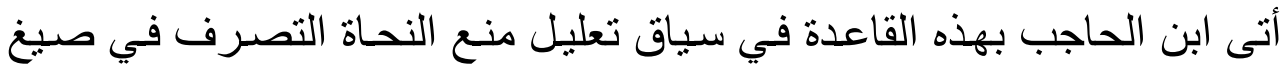

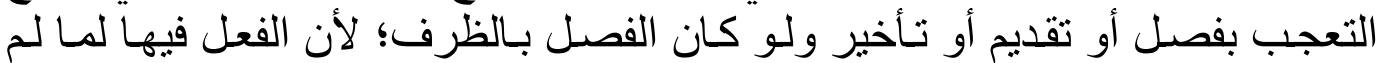

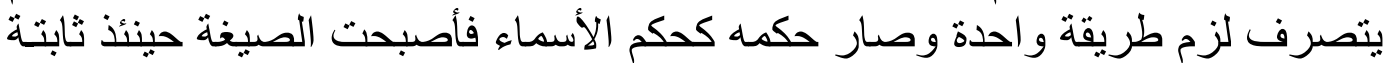

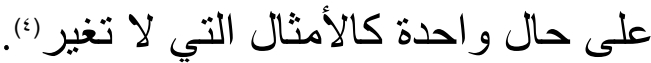

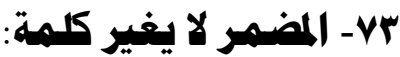

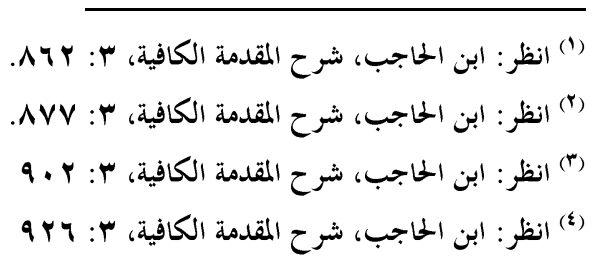


استخل ابن الحاجب بهذه القاعدة على امتتاع اتصـال الضمير بـ(حتى)؛ لأنها

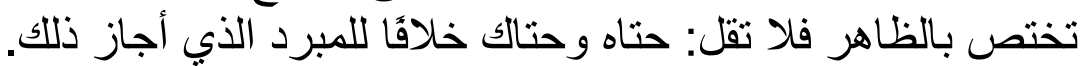

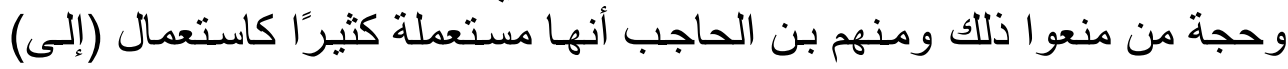
ولو كان ذلك جائزًا لوقع، ولو وقع لنقل مع توفر المستقرئين و الناقلين.

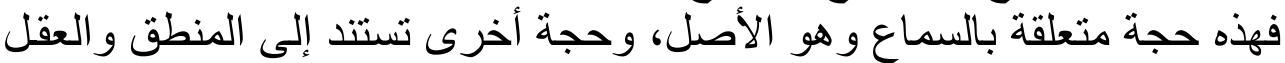

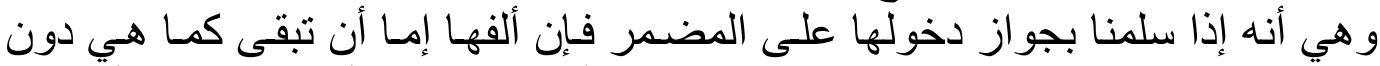

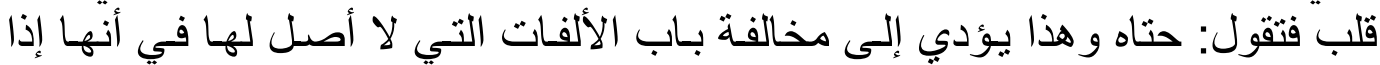

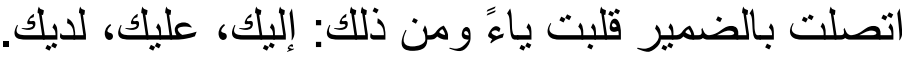

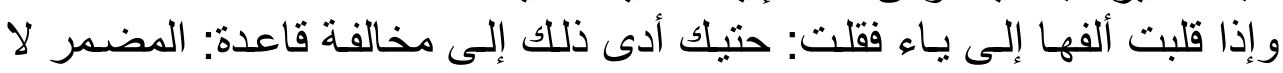

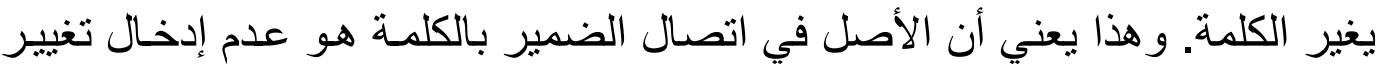

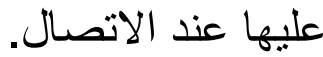

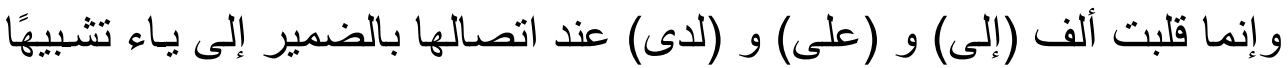

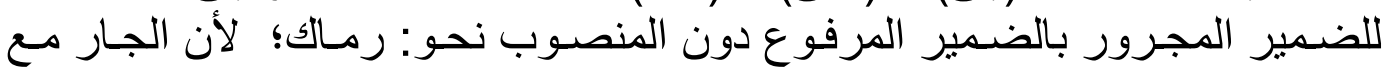

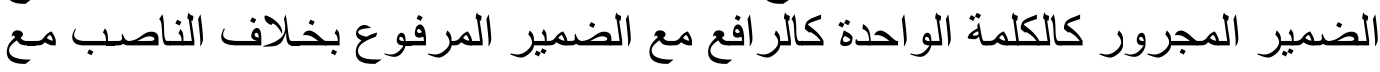

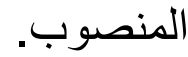

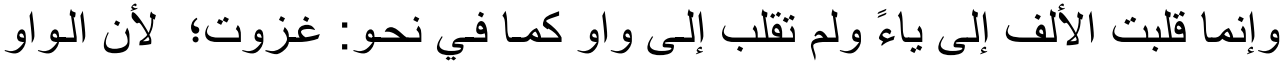

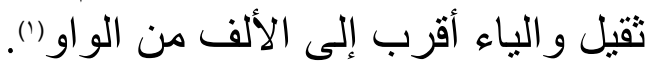

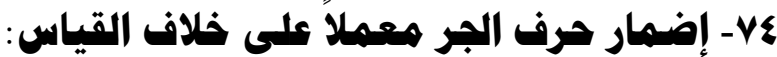

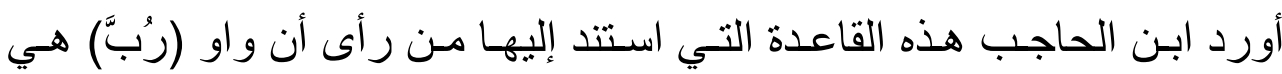

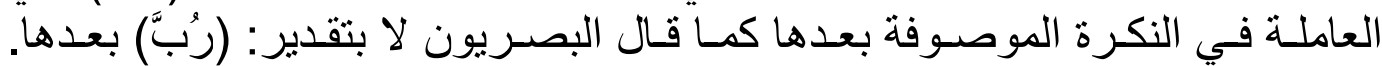
و الواو واو العطف كما ذهب إلى ذللك الكوفيون و المبرد ().

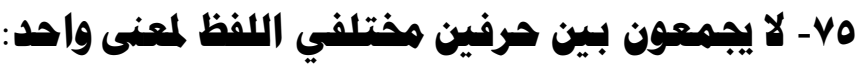

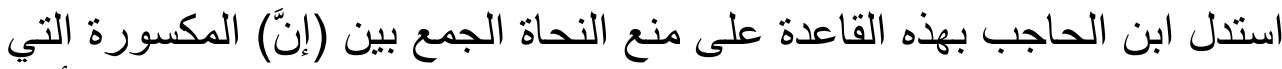

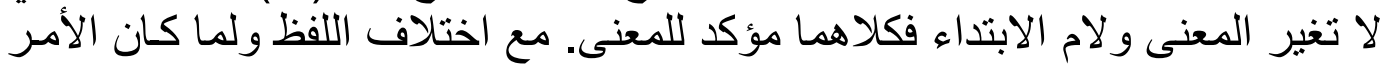

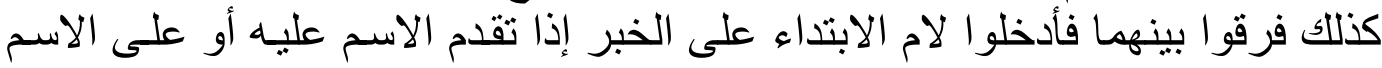

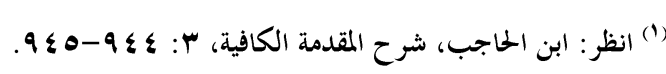

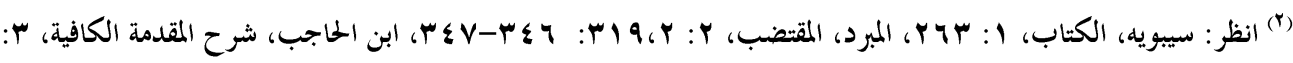

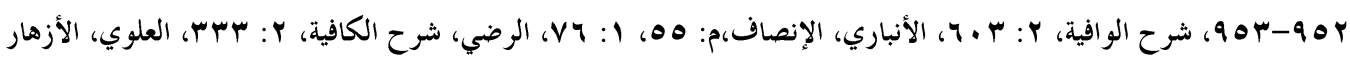

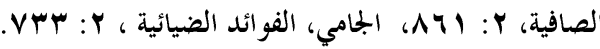


إذا فصل بينه وبين (إنَّ) بفاصل أو على متعلق الخبر. تقول: إنَّ زيدًا لقائم، و إنَّ في

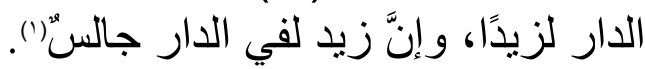

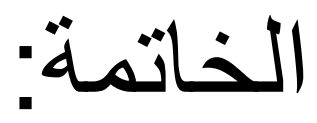

يخلص الباحث في نهاية البحث إلى النتائج الآتية:

1- أن أصول النحو بدأت بفكرة القياس، وهذه الفكرة نشأت في أحضان القياس الثرعي، ثم ترعرعت الفكرتان في أحضان المنطق، ثم دونت أصول الفقه كاملة، وصيغت صياغة منطقية، وجاءت من بعد ذلك أصول النحو مكتملة ناضجة في إطار منطقي على نحو أصول الفقه تمامًا. وتأسيسًا على ما سبق فإن قواعد التوجيه وهي أحد مكونات علم أصول الفقه والنحو معًا قد نشأت في أحضان أصول الققه ثم تلققها النحاة وكان لها أنز كبير في منهج التفكير النحوي للأصوليين من النحاة. r- أن قواعد التوجيه هي: قوانين تضبط ما ذكره النحاة من توجيه، وتنظر له، وقد صيغت إما للاستدلال على الحكم، أو تعليله لتقرير هذا الحكم، أو نفيه وهي بهذا تختلف عن قواعد الأبواب التي تتظر لمسائل الباب النحوي الواحد فقواعد التوجيه

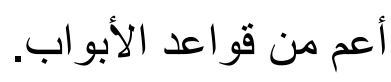

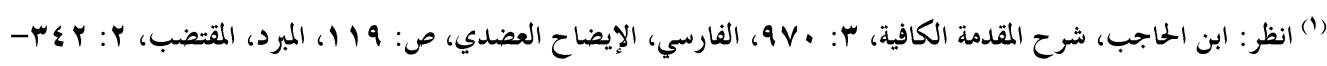


r-من مصادر قو اعد التوجيه عند النحاة: أنْ تكون قاعدة التوجيه من صياغة النحوي نفسه، أن يستقيد النحوي ممن سبقه في وضع قاعدة التوجيه.

r-من الأسباب التي أدت إلى اختلاف قواعد التوجيه بين النحاة: الخلاف الأصولي، الخلاف الفكري، اختلاف صياغة القاعدة .

ع- - بيان أثر هذه القواعد الأصولية عند الأصوليين من النحاة: ابن الحاجب أنموذجًا في مناقثة مسائل النحو ومنها ترجيح حكم على حكم أو تعليل على آخر أو تقوية دليل على آخر أو علة على علة. 


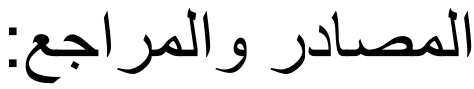

ه الإحكام في أصول الأحكام، الآمدي، دار الاتحاد العربي للطباعة ، نشر

$$
\text { وتوزيع مؤسسة الحلبي، VT } 97 \text { (م. }
$$

الاستدلال النحوي- نحو نظرية معاصرة لأصول النحو العربي- ، محمد

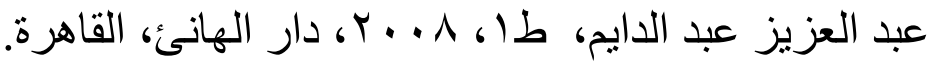

• أسرار العربية، لأبى البركات عبد الرحمن بن محمد بن أبى سعيد

الأنباري تحقيق/ محمد بهجة البيطار، دمشق مطبو عات المجمع العلىى

$$
\text { بيروت مطبعة الترقى بدمشق، I TVV }
$$


•الأشباه و النظائر في النحو، السيوطي، تحقيق: محمد عبد القادر

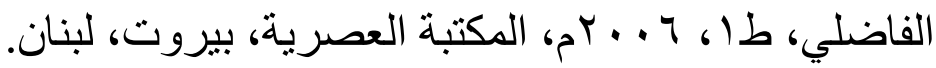
أصول التفكير النحوي ، علي أبو المكارم، طا، بل9 ام، منشورات الجامعة

أصول النحو العربي في نظر النحاة ورأي ابن مضاء في ضوء علم اللغة الحديث، محمد عيد، عالم الكتب، سV إم. أصول النحو (دراسة في فكر الأنباري)، محمد سالم صالح، طا، ج . . بم،

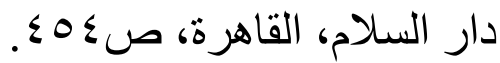

أصول النحو عند السيوطي بين النظرية، والتطبيق، عصام عيد فهمي أبو غريبة، طا، ؟ . . بم، الهيئة المصرية العامة للكتاب، القاهرة، مصر الأصول في النحو لابن السراج - تحقيق / عبد الحسين الفتلى مؤسسة الرسالة

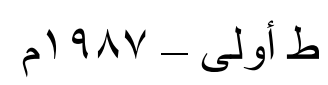

الإغراب في جدل الإعراب، ولمع الأدلة في أصول النحو، الأنباري، تحقيق

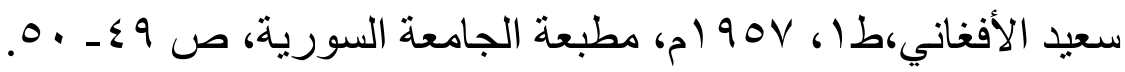
الاقتر اح، السيوطي، دار المعارف ، حلب، سوريا، د.ت. 
الاقتراح السيوطي، تحقيق: طه عبد الرؤوف، طا، 999 ام، مكتبة الصفا، القاهرة. - مرة

(الأم) ، تأليف: محمد بن إدريس الثنافعي أبو عبد الله، الطبعة الأولى الأميرية

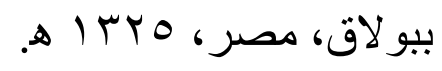

الإنصاف في مسائل الخلاف بين النحويين البصريين و الكوفيين ، الأنباري، تحقيق محمد محيب الدين، طا، 0 . . بام، دار الطلائع، القاهرة. أوضح المساللك إلى ألفية ابن ماللك، ابن هشام، تحقيق: محمد محي الدين عبد الحميد، طا، ع . . بم، دار الطلائع، القاهرة. الإيضاح في علل النحو ، الزجاجي، تحقيق د. مازن المبارك، طس، 9 9 ام، دار النفائس، بيروت. الإيضاح العضدي، الفارسي، تحقيق: حسن شاذلي فر هود، طا، مطبعة دار التأليف، مصر، تقويم الفكر النحوي ، علي أبو المكارم، طا، هـ ـ ـم، دار غريب، القاهرة. الجامع الصغير في النحو، ابن هثام، تحقيق: احمد محمود الهرميل، مكتبة الخانجي، القاهرة، · - (91 (م. 
•الجنى الداني في حروف المعاني ، المرادي، تحقيق: فخر الدين قباوة، و محمد نديم فاضل، طا، ب999 (م، دار الكتب العلمية، بيروت الخصائص، ابن جني، تحقيق: محمد علي النجار، دار الكتب المصرية، م) 1900

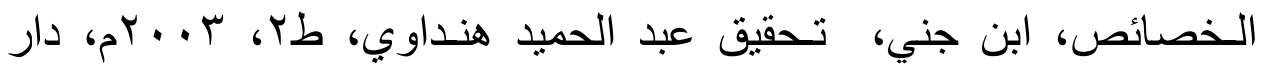

$$
\text { الكتب العلمية ، بيروت، ؟: }
$$

• الدر المصون في علوم الكتاب المكنون ، السمين الحلبي، تحقيق د. أحمد

$$
\text { الخرّاط، طا، } 919 \text { (ام، دار القلم، دمشق، } 1 \text { : } 91 .
$$

(الرسالة)، الثافعي، تحفيق: أحمد محمد شاكر ، الطبعة الأولى، · ؟9 ام.

سر صناعة الإعراب، ابن جني، تحقيق: د. حسن هنداوي، طا، ب99 (م،

$$
\text { دار القلم، بيروت. }
$$

• الثناهد وأصول النحو في كتاب سيبويه، خديجة الحديثي،طا، ع ا9 ام،

$$
\text { مطبو عات جامعة الكويت. }
$$

• شرح الألفية، (توضيح المقاصد و المسالك بشرح ألفية ابن مالك، المرادي، تحقيق: عبد الرحمن علي سليمان العثيمين، ط؟، مكتبة الكليات الأزهرية. 
شرح الأشموني ( منهج السالك إلى ألفية ابن ماللك)، الأشموني، مطبة عيسى

$$
\text { البابي الحلبي. }
$$

• شرح جمل الزجاجي، ابن عصفور الأشبيلي، تحقيق فواز الشعار، طا،

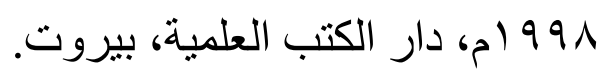

• شرح الكافية، الرضي، دار الكتب العلمية، بيروت.

شرح ملحة الإعراب، الحريري، مطبعة عيسى البابي الحلبي، 9؟ ا اهـ.

شرح الوافية، ابن الحاجب، تحقيق: طارق نجم الدين عبد الله، رسالة

ماجستير.

•الصاحبي في فقه اللغة ومسائلها وسنن العرب في كلامها، أحمد بن فارس،

تحقيق عمر الطباع، طا، س99 (م، مكتبة المعارف، بيروت، ص ال1 1.

• العلة النحوية نشأتها وتطورها، مازن المبارك، دار الفكر، الطبعة الثانية،

$$
\text { .) } 971
$$

(القاعدة النحوية دراسة نقدية تحليلية) د. أحمد عبد العظيم في كتابه طا،

99. - (99، دار الثقافة، القاهرة. 
القاموس المحيط، الفيروزأبادي، تحقيق مكتب تحقيق التراث في مؤسسة الرسالة، طس، ب99 (م، بيروت،

• قياس العكس في الجدل النحوي عند أبي البركات الأنباري، د. محمد بن علي العمري، رسالة دكتوراة 9؟أهـ، جامعة أم القرى، المملكة العربية

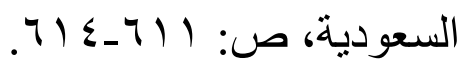

• قو اعد التوجيه في النحو العربي، عبد الله الخولي، رسالة دكتور اة، إثر اف أ.د. محمد عبد اللطيف حماسة، جامعة القاهرة، كلية دار العلوم، \99 ام كتاب الأصول دراسة إبستيمولوجية للفكر اللغوي عند العرب، تمام حسان،

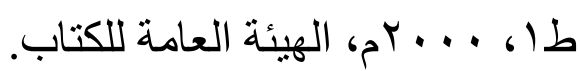
، كتاب الأصول في النحو، ابن السراج ، تحقيق د. عبد الحسين الفتلي، ط؟،

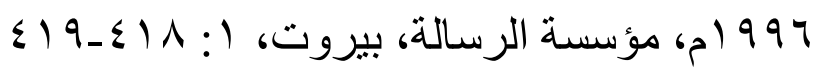
كتاب تعدد التوجيه النحوي (مو اضعه،أسبابه،نتائجه)، محمد حسنين صبرة، طا، دار غريب، ^ .. بام، القاهرة الكتاب ، سيبويه، تحقيق : عبد السلام هارون، طب، وVV ام، الهيئة المصرية العامة للكتاب، القاهرة. 
• الكتاب، سيبويه، تحقيق : عبد السلام هارون، طس، 911 (م، الخانجي،

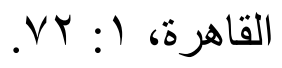

كتاب الخلاف النحوي بين البصريين و الكوفيين وكتاب الإنصاف، محمد خير

$$
\text { الحلواني، دار القلم العربي، طا، ـ \9 (م، حلب. }
$$

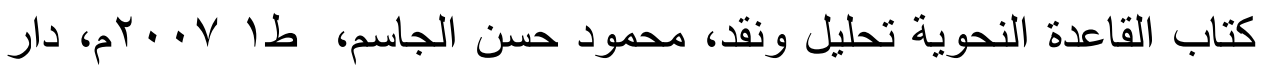

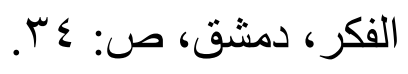

$$
\text { لسان العرب، ابن منظور طا، دار الحديث، ج +. . بم، القاهرة }
$$

اللمع، ابن جني، تحقيق: محمد حسين محمد محمد شرف، عالم الكتاب، طا،

$$
\text { 5) } 9 \vee 9
$$

• لمع الأدلة ، الأنباري، حقيق الأستاذ/سعيد الأفغاني، مطبعة الجامعة

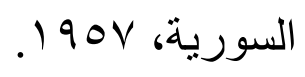

• ما ينصرف وما لا ينصرف، الزجاج، تحقيق: هدى قراعة، لجنة إحياء

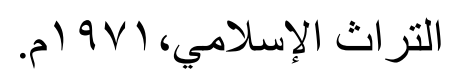

الددارس النحوية، شوقي ضيف، طV، ب99 ام، دار المعارف.

المرتجل، ابن الخشاب، تحقيق: علي حيدر، دمشق، YVY ام. 
المسائل البصريات، الفارسي، تحقيق:د. محمد الشاطر، طا، 910 (م،

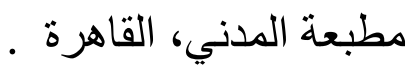

المسائل الحلبيات، الفارسي، تحقيق د. محمد الثاطر، طا، بر91 (م، مطبعة

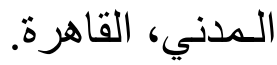

المسائل الخلافية في الإنصاف و أسرار العربية، دراسة تحليلية نقدية، د.أحمد جمال الدين ، رسالة دكتوراة ا .. بم، إثر اف أ. د.محمد عبد الدجيد الطويل،

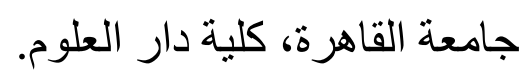

مشكل إعراب القرآن، مكي بن أبي طالب القيسي، تحقيق: ياسين محمد

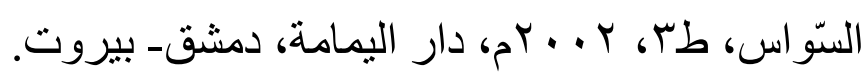

المطالع السعيدة في شرح الفريدة، السيوطي، تحقيق: نبهان ياسين حسين،

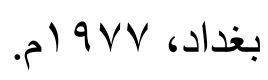

معاني القرآن، الفراء، تحقيق: أحمد نجاتي، ومحمد النجار، ط؟، 900 (م، الهيئة المصرية العامة للكتاب، القاهرة. • معاني القرآن وإعرابه ، الزجاج، تحقيق: د. عبد الجليل شلبي، طا،

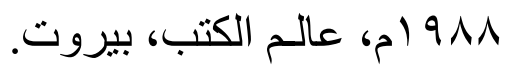


مغني اللبيب عن كتب الأعاريب، ابن هشام، تحقيق د. عبد اللطيف الخطيب، طا، . . . זم، المجلس الأعلى للثقافة، الكويت.

• المقاصد الثافية في شرح الخلاصة الكافية، الثناطبي، تحقيق: د.عبد الرحمن سليمان العثيمين، طا، V ...Tم، معهد البحوث العلمية، وإحياء التراث الإسلامي، جامعة أم القرى، مكة المكرمة.

المقتصد في شرح الإيضاح، الجرجاني تحقيق: كاظم بحر المرجان، طا، r 9 (م، دار الرشيد، منشورات وزارة الثقافة، والإعلام، العراق. المقتضب، المبرد، تحقيق: عبد الخالق عضيمة، طبعة المجلس الأعلى للثيؤون

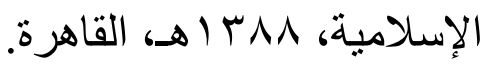

المقتضب، المبرد، تخفيق: محمد عبد الخالق عضيمة، لجنة إحياء التراث

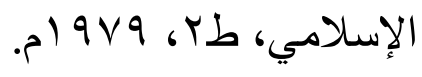

مناهج تجديد، أمين الخولي، دار المعرفة، الطبعة الأولى، (79 ام. ،نتائج الفكر، السهيلي تحقيق د. محمد إبراهيم البنا، طب، عـ911، دار

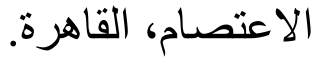

همع الهوامع في شرح جمع الجوامع ، السيوطي، تحقيق أحمد شمس الدين، طا، 1991ام دار الكتب العلمية ، بيروت 